\title{
A MATRIZ INSUMO-PRODUTO INTERNACIONAL DO MERCOSUL EM 1990: A DESIGUALDADE REGIONAL E O IMPACTO INTERSETORIAL DO COMÉRCIO INTER-REGIONAL
}

\section{MARCO ANTONIO MONTOYA RODRIGUEZ}

Economista

Orientador: Prof. Dr. JOAQUIM J. M. GUILHOTO

Tese apresentada à Escola Superior de Agricultura "Luiz de Queiroz", Universidade de São Paulo, para obtenção do título de Doutor em Ciências. Área de concentração: Economia Aplicada

PIRACICABA

Estado de São Paulo - Brasil

Março - 1998 
DIVISÃo DE BIBLIOTECA E DOCUMENTAÇÃO - Campus "Luiz de Queiroz" /USP

Montoya Rodriguez, Marco Antonio

A matriz insumo-produto internacional do Mercosul em 1990: a desigualdade regional e o impacto intersetorial do comércio inter-regional / Marco Antonio Montoya Rodriguez. - - Piracicaba, 1998.

217 p.

Tese (doutorado) - - Escola Superior de Agricultura Luiz de Queiroz, 1998.

Bibliografia.

1. Comércio exterior 2. Demanda 3. Equilíbrio econômico 4. Integração econômica 5. Mercosul 6. Oferta 7. Relação insumo-produto 8. Relação intersetorial I. Título 


\title{
A MATRIZ INSUMO-PRODUTO INTERNACIONAL DO MERCOSUL EM 1990: A DESIGUALDADE REGIONAL E O IMPACTO INTERSETORIAL DO COMÉRCIO INTER-REGIONAL
}

\author{
MARCO ANTONIO MONTOYA RODRIGUEZ
}

Comissão julgadora:

Prof. Dr. Joaquim J. M. Guilhoto

Prof. Dr. Paulo Fernando Cidade de Araújo

Prof. Dr. Joaquim Bento de Souza Ferreira Filho

Prof. Dr. Antônio Salazar Pessoa Brandão

Prof. Dr. Maria da Conceição Sampaio de Souza
ESALQ/USP

ESALQ/USP

ESALQ/USP

IBRE/FGV

Dept.Econ./UnB

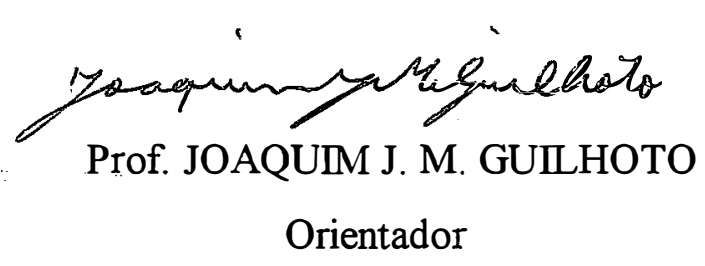


À memória de meus avôs Daniel e Mercedes.

A meus pais e irmãos que, embora distantes, sempre acompanham de perto 0 meu desenvolvimento.

À minha esposa Cássia e aos meus fillhos Gabriel e Vinícius. Desculpem-me pelo tempo subtraído de um convívio familiar mais intenso. 


\section{AGRADECIMENTOS}

A realização deste trabalho não teria sido possível se não contasse com a colaboração de diversas pessoas e instituições, às quais gostaria de expressar publicamente meu reconhecimento.

Ao prof. Joaquim José Martins Guilhoto, pela valiosa orientação, incentivos constantes e amizade demostrada.

Aos profs. Paulo Fernando Cidade de Araújo e Joaquim Bento de Souza Ferreira Filho, pelas críticas e sugestões apresentadas.

Ao prof. Rodolfo Hoffmann, pelos comentários sobre as primeiras idéias deste trabalho, quando ainda eram os primeiros esboços de um projeto de pesquisa.

Ao prof. Geraldo Sant'ana de Camargo Barros, pelo apoio durante minha permanência em Piracicaba.

Aos professores e funcionários do Departamento de Economia e Sociologia Rural da Esalq/Usp, pelos ensinamentos e amizade.

À Universidade de Passo Fundo, pela liberação total das minhas atividades durante o curso de doutorado.

À Capes que, através do Programa PICD, prestou auxílio financeiro ao autor.

À Aladi (Montevidéu), na pessoa do Sr. Raulino de Oliveira; ao Inta (Buenos Aires), na pessoa do Sr. Júlio Penna; e à Cepal (Brasília), na pessoa do Sr. Carlos Mussi, pelo fornecimento de dados.

À Sra. Maria Emilse Lucatelli, pela competente e criteriosa revisão do texto.

Ao Sr. Adrovane Marques Kade, pelo auxílio na editoração do texto.

Aos colegas de pós-graduação, pela amizade e agradável convivência durante o curso.

Aos meus familiares em geral, pelo incentivo moral que me brindaram em todo momento nesta etapa de minha formação.

E, por fim, a todas as demais pessoas e instituições que, de uma forma ou outra, colaboraram para a realização deste trabalho. 


\section{SUMÁRIO}

\section{Página}

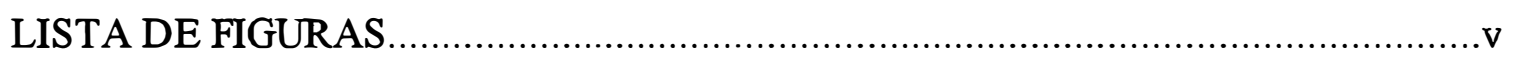

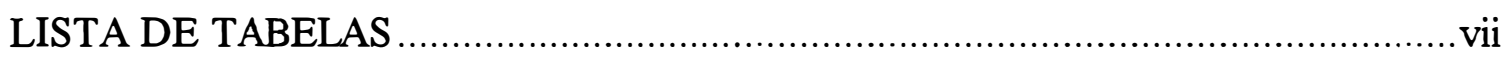

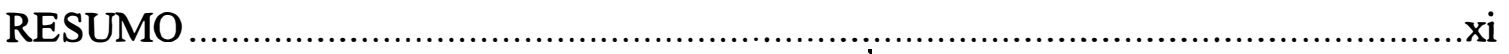

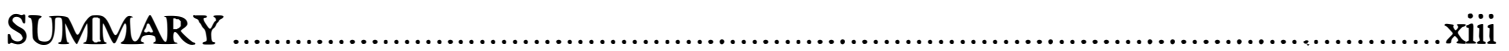

1 INTRODUCÃO

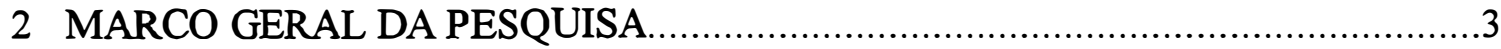

2.1 Aspectos teóricos das desigualdades regionais versus a nova tendência da

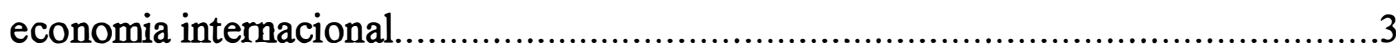

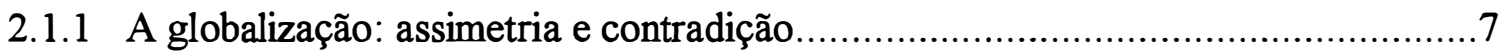

2.1.2 A regionalização: integração econômica e desigualdade regional ........................9

2.2 O Mercosul: problema de pesquisa e sua justificativa ......................................... 14

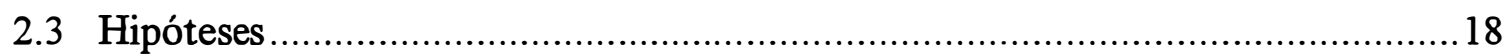

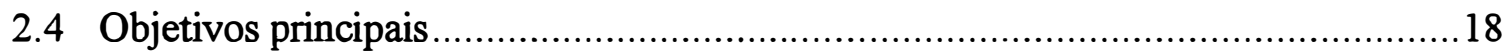

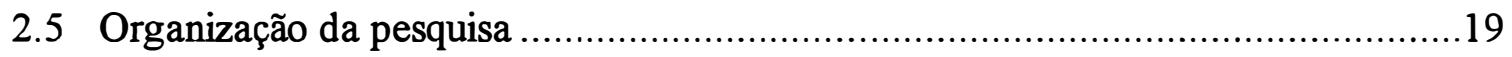

3 A INTEGRAÇÃO ECONÔMICA, OS NOVOS DESAFIOS E A NECESSIDADE DE UM INSTRUMENTAL DE ANÁLISE SISTÊMICO NA REGIÃO …................21

3.1 Antecedentes da integração na América Latina: da busca de identidade política a uma política alternativa de desenvolvimento

3.2 A experiência das décadas de 1960 e 1970: a atuação da Alalc e as inovações

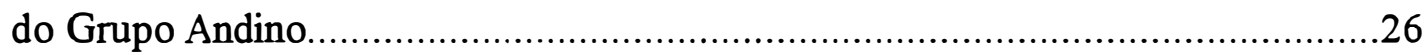

3.3 A flexibilidade das ações na década de 1980 frente às desigualdades regionais ......30

3.4 A década de 1990: renovado vigor, a abertura e o liberalismo econômico ...............33 
3.5 Os novos desafios e a necessidade de um instrumental sistêmico de análise que se colocam para a integração na região

4 TEORIA E QUADRO GERAL DOS MODELOS INSUMO-PRODUTO …............39

4.1 A teoria básica dos modelos de insumo-produto ................................................... 39

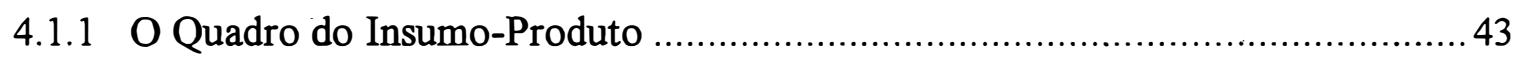

4.2 Os modelos inter-regionais e internacionais de insumo-produto ...........................47

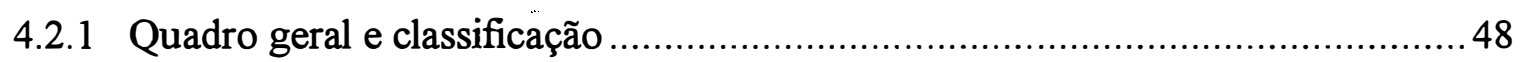

4.3 Os modelos com informação censitária: alcance e limitações ..............................53

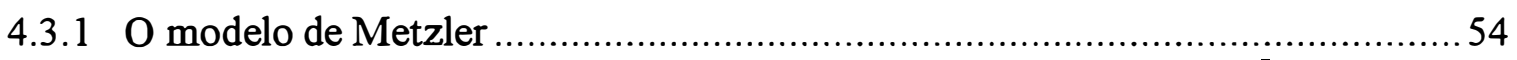

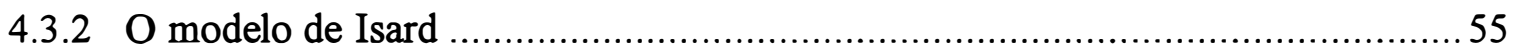

4.4 Os modelos com informação censitária limitada: alcance e limitações ..................56

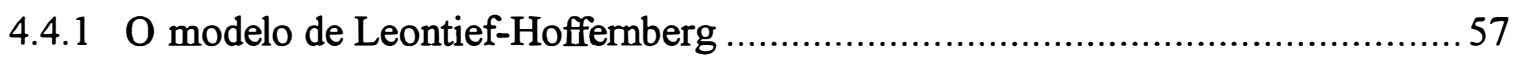

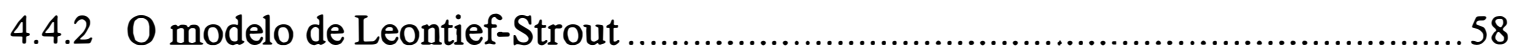

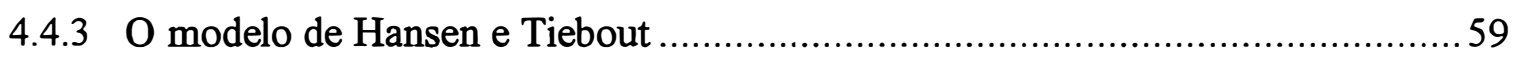

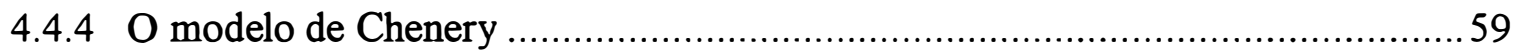

4.5 Os modelos internacionais: alcance e limitações .................................................. 61

5 METODOLOGIA DE CONSTRUÇÃO DO MODELO INSUMO-PRODUTO INTERNACIONAL DO MERCOSUL E SEU PROCESSO DE COMPILAÇÃO ..... 63

5.1 Consideraç̃̃es gerais sobre a seleção do modelo de construção............................. 63

$5.2 \mathrm{O}$ modelo de insumo-produto multilateral proposto para o Mercosul.....................66

5.2.1 Estimativa das relações interindustriais entre países parceiros .......................... 70

5.2.2 Estimativa do frete e do seguro internacional ............................................. 75

5.2.3 Reconciliação do quadro insumo-produto multilateral ....................................77

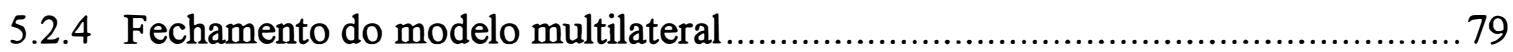

5.3 Processo de compilação do quadro insumo-produto multilateral do Mercosul .......81

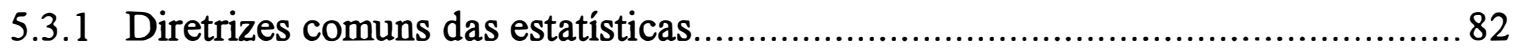

5.3.2 Definição da unidade de preços no sistema econômico ......................................82 
5.3.3 Definição da unidade monetária e ano base do sistema econômico .83

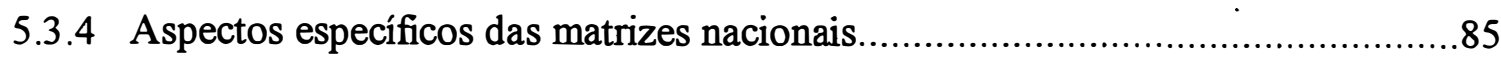

5.3.5 Compatibilização, classificação e agregação setorial uniforme..........................86

6 O PERFIL DAS ESTRUTURAS DE TRANSAÇÕES INTERNACIONAIS E OS SETORES-CHAVE NA ECONOMIA DO MERCOSUL EM 1990 ................89

6.1 A dimensão econômica e o perfil das estruturas de transações internacionais ........89

6.1.1 A integração espacial dos mercados...........................................................93

6.2 As ligações industriais e os setores-chave ................................................ 98

6.2.1 Os índices de Rasmussen - Hirschman .................................................... 100

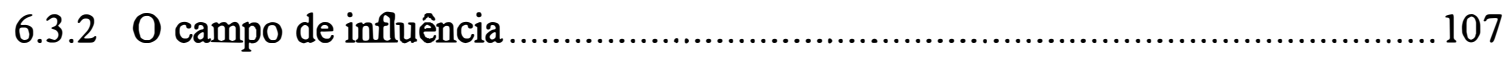

6.3.3 Os índices puros de ligações .............................................................. 111

7 A INFLUÊNCIA DAS DEMANDAS FINAIS SOBRE A PRODUÇÃO, O VALOR ADICIONADO E O COMÉRCIO EXTERNO NO MERCOSUL EM 1990 ............. 117

7.1 Demanda final e produção .................................................................... 118

7.1.1 Produção agregada induzida pelas demandas finais e pelas exportações para o

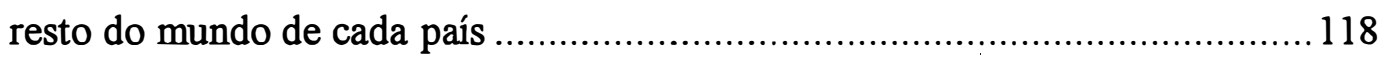

7.1.2 Coeficiente da produção induzida da demanda final para cada país parceiro ..... 122

7.1.3 Produção setorial induzida pelas demandas finais e pelas exportações para o resto do mundo de cada país

7.1.4 Importância relativa dos fluxos de comércio internacional para a produção induzida nos países do Mercosul

7.2 Demandas finais e valor adicionado

7.2.1 Valor adicionado agregado induzido pelas demandas finais e pelas exportações para o resto do mundo de cada país

7.2.2 Coeficiente do valor adicionado induzido pela demanda final de cada país parceiro 
7.2.3 Valor adicionado setorial induzido pelas demandas finais e pelas exportações para

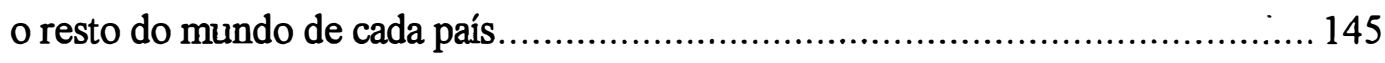

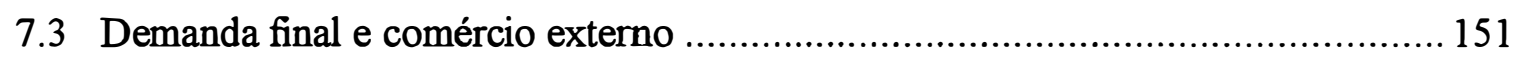

7.3.1 Importações agregadas induzidas pelas demandas finais de cada país............... 151

7.3.2 Coeficiente de importação indurida pela demanda final de cada país................ 154

7.3.3 Exportações induzidas pelas demandas finais de cada país ............................... 157

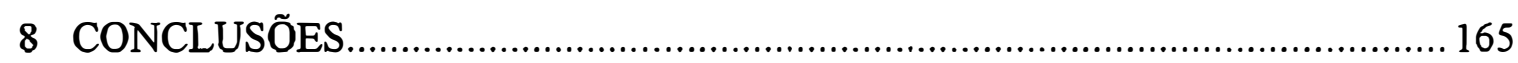

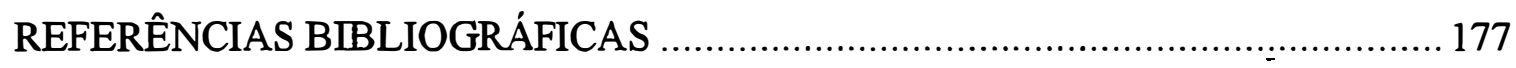

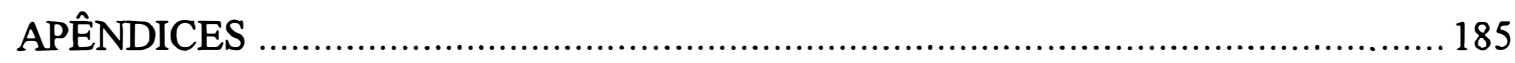




\section{LISTA DE FIGURAS}

Página

Figura 4.1 - Classificação dos modelos insumo-produto inter-regionais e sua extensão para os modelos de insumo-produto internacionais.

Figura 6.1 - Participação da produção exportada para o resto do mundo e para o Mercosul sobre o produto total .95

Figura 6.2 - Participação dos insumos importados de uso intermediário provenientes do resto do mundo e do Mercosul sobre o total de insumos.

Figura 6.3 - Síntese dos padrões de comportamento dos índices de Rasmussem e Hirschman para os países do Mercosul. 102

Figura 6.4 . Coeficientes setoriais com maior campo de influência no Mercosul.

Figura 6.5. Índice puro de ligações para frente no Mercosul

Figura 6.6 - Índice puro de ligações para trás no Mercosul. 114

Figura 7.1 - Participação da produção agregada induzida pelas demandas finais e pelas exportações para o resto do mundo sobre o total de produção induzida de cada país.

Figura 7.2 - Produção setorial induzida que depende da demanda final doméstica nos países-membros do Mercosul (oito grandes setores para cada país)

Figura 7.3 - Dependência setorial domética versus produção setorial na Argentina. .... 127

Figura 7.4 - Dependência setorial domética versus produção setorial no Brasil. 127 
Figura 7.5 - Dependência setorial domética versus produção setorial no Chile. 128

Figura 7.6 - Dependência setorial domética versus produção setorial no Uruguai 128

Figura 7.7 - Participação da produção induzida pelas demandas finais e pelas exportações para o resto do mundo sobre as exportações de cada país..... 133

Figura 7.8 - Participação do valor adicionado induzido pelas demandas finais e pelas exportações para o resto do mundo sobre o total de valor adicionado induzido de cada país

Figura 7.9 - Padrão de dependência e produção doméstica dos países do Mercosul....141

Figura 7.10 - Dependência doméstica versus coeficiente do valor adicionado induzido doméstico 


\section{LISTA DE TABELAS}

Página

Tabela 4.1. Estrutura básica geral do quadro insumo-produto.

Tabela 4.2. Quadro de insumo-produto simplificado segundo o modelo de Leontief. ....44

Tabela 5.1. Quadro simplificado do modelo insumo-produto multilateral proposto para o Mercosul.

Tabela 5.2. Taxa de Câmbio do dolar médio corrente (rf) em cada país e Índice de Preços ao Atacado dos Estados Unidos

Tabela 6.1. Matriz insumo-produto do Mercosul para 1990 em milhões de dólares correntes

Tabela 6.2. Integração espacial dos mercados do ponto de vista das exportações.

Tabela 6.3. Integração espacial dos mercados do ponto de vista das importações.

Tabela 6.4. Índices de ligações de Rasmussen e Hirschman para o Mercosul - 1990 ... 101

Tabela 7.1. Produção agregada induzida pelas demandas finais e pelas exportações para o resto do mundo de cada país (US\$ milhões correntes de 1990)......119

Tabela 7.2. Coeficiente de produção induzida da demanda final para cada país.

Tabela 7.3. Contribuição das demandas finais sobre a produção induzida setorial de cada país (acima de 1\%). 
Tabela 7.4. Total valor adicionado induzido pela demanda final de cada país e do resto do mundo, em milhões de dólares correntes de 1990.

Tabela 7.5. Dependência do valor adicionado induzido pela demanda final de cada país e do resto do mundo, em percentuais.

Tabela 7.6. Coeficiente do valor adicionado induzido pela demanda final para cada país.

Tabela 7.7. Contribuição das demandas finais e das exportações para o resto do mundo no valor adicionado setorial induzido da Argentina, em milhões de dólares correntes de 1990 .

Tabela 7.8. Contribuição das demandas finais e das exportações para o resto do mundo no valor adicionado setorial induzido do Brasil, em milhões de dólares correntes de 1990.

Tabela 7.9. Contribuição das demandas finais e das exportações para o resto do mundo no valor adicionado induzido setorial do Chile, em milhões de dólares correntes de 1990 .

Tabela 7.10. Contribuição das demandas finais e das exportações para o resto do mundo no valor adicionado setorial induzido do Uruguai, em milhões de dólares correntes de 1990 .

Tabela 7.11. Valor das importações intermediárias induzidas pela demanda final de cada país do Mercosul (em milhões de dólares de 1990).

Tabela 7.12. Coeficiente de importação induzida da demanda final para cada país. ..... 154

Tabela 7.13. Importações induzidas pela demanda final do Chile (acima de US\$10 milhões) 
Tabela 7.14. Importações induzidas pela demanda final do Uruguai (acima de US\$ 5 milhões).

Tabela 7.15. Exportações induzidas pela demanda final de cada país no Mercosul ......158

Tabela 7.16. Exportações inter-regionais induzidas das dez maiores indústrias da Argentina.

Tabela 7.17. Exportações inter-regionais induzidas das dez maiores indústrias do Brasil.

Tabela 7.18. Exportações inter-regionais induzidas das dez maiores indústrias do Chile.

Tabela 7.19. Exportações inter-regionais induzidas das dez maiores indústrias do Uruguai.

Tabela A1.1. Classificação setorial da demanda intermediária da matriz insumoproduto internacional do Mercosul 1990 189

Tabela A1.2. Classificação setorial da demanda finala da matriz insumo-produto internacional do Mercosul 1990 190

Tabela A1.3. "Coordenada" da matriz insumo-produto internacional do Mercosul: descrição das linhas 190

Tabela A1.4. "Coordenada" da matriz insumo-produto internacional do Mercosul: descrição das colunas. 190

Tabela A1.5. Matriz insumo-produto internacional do Mercosul - 1990 (em milhöes de dólares correntes) 
Tabela A2.1. Produção induzida setorial doméstica da demanda final de cada paísmembro do Mercosul (em milhões de dólares e percentuais)

Tabela A2.2. Valor adicionado induzido setorial da demanda final de cada país-membro do Mercosul (em milhões de dólares e percentuais)

Tabela A2.3. Valor das importações inter-regionais induzidas pela demanda final de cada país-membro do Mercosul (em milhões de dolares) 215 


\title{
A MATRIZ INSUMO-PRODUTO INTERNACIONAL DO \\ MERCOSUL EM 1990: A DESIGUALDADE REGIONAL E $O$ \\ IMPACTO INTERSETORIAL DO COMÉRCIO INTER-REGIONAL
}

\author{
Autor: MARCO ANTONIO MONTOYA RODRIGUEZ \\ Orientador: Prof. Dr. JOAQUIM J. M. GULHOTO
}

RESUMO

Este estudo analisa os processos de interdependência intersetorial entre os · países-membros do Mercosul, procurando caracterizar, de forma sistêmica, o perfil das estruturas de transações internacionais e setores-chave, bem como identificar e avaliar os possíveis efeitos da maior interdependência comercial na região. Com esses fins, foi construído e implementado, para o ano de 1990, um modelo insumo-produto internacional para o Mercosul do tipo multilateral.

Verificou-se que: a dimensão econômica dos mercados de cada país nas estruturas de transações insumo-produto aponta, inequivocamente, que a ampliação do potencial do mercado entre os países num processo integracionista é extremamente desigual; os níveis relativos da integração espacial dos mercados da Argentina e do Brasil e, em menor grau, do Chile e do Uruguai com o mercado mundial são limitados, adquirindo características dramáticas quando relacionados ao Mercosul; as ligações industriais apresentam dois padrões bem diferenciados, ou seja, ligações industriais fortes no Brasil e fracas na Argentina, Chile e Uruguai; os setores-chave de alcance interregional indicam que os principais elos de ligações inter-regionais da economia do Mercosul são dominados, em sua maior parte, pelos setores-chave vinculados à economia 
brasileira. Portanto, conclui-se que o processo de integração econômica do Mercosul não é conseqüência natural de fluxos de comércio intensos, mas, sim, de um processo provocado em função da conjuntura econômica internacional, na qual a integração é apenas uma alternativa plausível para a convivência com o processo de globalização das economias. Contudo, considerando que os mercados dos países mostram-se potencialmente complementares, o perfil de mais rápida e maior interdependência setorial na região será determinado pelo Brasil em virtude de sua melhor articulação industrial, processo que se fará principalmente a partir dos setores metalúrgica, têxtil e agropecuária, até porque estes setores participam nas cadeias-chave da Argentina, Chile e Uruguai.

Com respeito aos efeitos de maior interdependência comercial, verificouse que: os coeficientes de produção induzida indicam uma forte relação entre a demanda final dos países e a produção doméstica; o confronto entre a produção doméstica total per capita e a participação relativa do valor adicionado induzido doméstico sugere que a dependência externa do Chile e do Uruguai nos próximos anos, em termos relativos, aumentará bem mais que a dependência da Argentina e do Brasil; na geração de valor adicionado, a participação dos setores primários é mais relevante nas economias da Argentina, Chile e Uruguai do que no Brasil. Portanto, conclui-se que a economia brasileira será um supridor importante de produtos acabados de materiais básicos industriais e de bens de capital para os países do Mercosul. Nesse contexto, na complementaridade econômica dos mercados, existirá uma tendência à especialização no comércio inter-regional de setores que apresentam, radicionalmente, os maiores volumes negociados, havendo uma diversificação ampla do comércio em setores de menores volumes negociados, já que o intercâmbio neste nível processa-se entre setores primários e secundários da mais variada índole. 


\title{
THE INTERNATIONAL INPUT-OUTPUT TABLES OF MERCOSUR IN 1990: THE REGIONAL UNEQUALTY AND THE INTERSECTORAL IMPACT IN THE INTEREGIONAL MARKET
}

\author{
Author: MARCO ANTONIO MONTOYA RODRIGUEZ \\ Adviser: Prof. Ph.D. JOAQUIM J. M. GUILHOTO
}

SUMMARY

This study analyses the processes of intersectoral internal and external dependence sectors among the countries that form Mercosur. It is searched to characterize the international transaction outlines and a key-sector in a systemic way as well as to identify and to evaluate the possible effects of the biggest independent market of the region. Therefore, in 1990 it was built and improved an international input-output model of multilateral type for Mercosul.

It was noticed that the economic dimension of each country's market in the input-output structure precisely shows that the amplifying of the potencial market among the countries in a process of integration is extremely unequal; the relative degrees of integration between the Brazilian and Argentinian markets and, in a lower degree, the Chilean and the Uruguayan with the world market is pretty limited, obtaining impressive characteristics when related to Mercosul; the industrial chains show two patterns very distinct: the strong industrial chain in Brazil and the weak ones in Argentina, Chile and Uruguay; the key-sectors among the regional reach indicates that the main link of the midst chains of Mercosur economy are dominated, in its majority, by the key-sectors linked to the Brazilian economy. Therefore, it concludes that the process of economy 
integration of Mercosur is not a natural consequence of the intense market flux, but from a process provoked by the international economic conjuncture, in which the integration is only a plausible alternative for the acquaintance with the globalization process of the economies. Nevertheless, considering that the markets of the countries show themselves potentially complemented, the profile of a quicker and bigger section interdependence in the region will be determined by Brazil due to its better industrial articulation, a process that will be well-succeeded itself mainly what it concerns metallurgic, textile and agrocattle sectors. This is because these sectors take part of the Argentinian, Chilean and Uruguayan key-chains.

Considering the effects of a bigger commercial interdependence, it was verified that the induced production numbers indicate a strong relationship between the final demand of the countries and the domestic production; the parallel of the total domestic production per capit and the relative participation of the induced domestic added value, in a way, suggests the external dependence of Chile and Uruguay within the next years will grow more than the dependence of Argentina and Brazil; in the creation of induced added value, the participation of the primary sectors are more relevant in the Argentinian, Chilean and Uruguayan economies than in then Brazilian. Therefore, it concludes that the Brazilian economy will be an important supplier of finished products of basic industrial materials and capital assets for the countries that take part of Mercosur. In this context, in the complementary economy of the markets, will exist a tendency to the specialization in the interregional market of sectors that traditionally present the biggest negociated goods, since that the exchange in its level, processes within primary and secondary levels of a diversified propensity. 


\section{INTRODUÇÃO}

Muito se tem discutido sobre o processo de globalização econômica e as vantagens teóricas da formação de blocos econômicos, como é o caso do Mercosul. Porém, uma questão, de suma importância e ainda pouco discutida de forma empírica, é: dadas as gritantes desigualdades de desenvolvimento econômico nas estruturas de produção e consumo dos países da região, as relações intersetoriais que se estabelecem com a aceleração do comércio inter-regional resultarão num crescimento econômico conjunto dos países, ou irão promover um crescimento concentrado em alguns deles?

Esta pesquisa trata dessa questão, que, muitas vezes, passa desapercebida ou permanece na retórica dos discursos, apesar de ser de fundamental importância para que o processo de integração inter-regional obtenha sucesso; até porque as gritantes desigualdades de desenvolvimento econômico existentes entre os países têm sido uma das principais causas, senão a principal, de discórdias e conflitos no seio dos diversos esquemas de integração na América Latina.

A análise resgata alguns fatos mais evidentes que caracterizam a experiência integracionista do continente. Sob o enfoque da teoria clássica de equilíbrio geral e através da construção e implementação de um modelo insumo-produto internacional para o Mercosul, avaliam-se os processos de interdependência setorial dos países, analisando a dimensão econômica e a integração espacial dos mercados, o perfil das estruturas de transações internacionais, as ligações industriais e os setores-chave nacionais e de alcance inter-regional .

Levando em conta que o primeiro impacto da integração econômica regional modifica os componentes das demandas dos países, mensura-se também a influência das demandas finais sobre a produção, sobre o valor adicionado e sobre o 
comércio externo, de forma a buscar um melhor entendimento da integração econômica entre países com desenvolvimento econômico heterogêneo.

Em síntese, esta pesquisa identifica de forma sistêmica os efeitos de uma maior interdependência comercial, bem como fornece subsídios para a construção de políticas econômicas tendentes ao desenvolvimento econômico na região num processo de integração econômica. 


\section{MARCO GERAL DA PESQUISA}

Neste capítulo, faz-se o levantamento de algumas questões teóricas que delimitam o problema focalizado pela pesquisa, bem como salientam-se alguns elementos de juízo e antecedentes que dizem respeito à importância e atualidade do tema; levanta-se, também, uma hipótese, propõem-se objetivos e descreve-se a organização da pesquisa.

\subsection{Aspectos teóricos das desigualdades regionais versus a nova tendência da economia internacional}

Em nível internacional, as diferenças de renda per capita, produção, consumo, oportunidades de investimento, etc., entre países e regiões de um mesmo país são comumente tratadas pela teoria do crescimento econômico como desequilíbrios regionais, que levam, ao final, por assim dizer, à "concentração regional do desenvolvimento econômico". Este tratamento vem sempre associado a uma conotação negativa das desigualdades existentes.

Para entender o fenômeno, é fundamental saber se essas diferenças regionais são conseqüência lógica do funcionamento do sistema econômico de mercado, ou fruto de fatores políticos, ou de interesses de grupos sociais e/ou econômicos localizados em determinadas regiões ou países. Nesse sentido, estudos sobre o crescimento econômico apresentam-se sob duas visões antagônicas: a visão convergente, a qual considera que o desenvolvimento econômico será acompanhado pela diminuição das desigualdades regionais, e a visão divergente, segundo a qual o desenvolvimento econômico acabará aumentando as desigualdades (Azzoni, 1993). 
Estudos empíricos têm demonstrado que o processo divergente é predominante, principalmente porque, em geral, o crescimento econômico pode ocorrer de modo muito concentrado espacial e setorialmente, dando origem, em nível nacional, à região central ou pólo nacional urbano/industrial e à região periférica e, em nível internacional, aos países centrais desenvolvidos e aos países periféricos em desenvolvimento. ${ }^{1}$

A possibilidade de o pólo de crescimento nacional e pólos de crescimento internacional exercerem efeitos negativos sobre as regiões menos desenvolvidas foi salientada por Myrdal (1968). O autor afirma que o mecanismo que provoca e amplia as desigualdades entre regiões de um país e, por extensão, entre países reside, fundamentalmente, nos princípios da causação circular e da acumulação do circuito vicioso da pobreza ${ }^{2}$, princípios estes que explicam, no processo histórico, uma funcionalidade econômico-social descendente e ascendente.

Enquanto um pólo de crescimento nacional ou região central cresce com altas taxas, as demais regiões perdem participação no produto nacional; simultaneamente, a deterioração dos termos de troca, suscetível de ocorrer entre as nações, também pode reproduzir-se entre as diferentes regiões no interior dos países,

${ }^{1}$ Em nível internacional, a Comissão de Estudos para América Latina (Cepal), a partir dos trabalhos de Prebisch (1950), implementou um conjunto de estudos que discutiam os problemas dos países da região. As relações de troca entre os países desenvolvidos e os países em desenvolvimento foram salientadas como um problema fundamental para que se estabeleça um crescimento sustentado na região. Entretanto, a evidência empírica não foi conclusiva. Já a evidência empírica em nível nacional é mais conclusiva em alguns casos, como o da transição demográfica, mas pouco esclarecedora no tocante à distribuição do tamanho de cidades e, principalmente, à distribuição pessoal da renda e às desigualdades regionais. No âmbito da distribuição pessoal da renda, a evidência brasileira insiste em contrariar a tese da "convergência"(Azzoni, 1985); contudo, até 1985, segundo Ferreira \& Diniz (1995), existe uma tendência à convergência entre as rendas per capita dos estados no Brasil, apesar das brutais diferenças na distribuição interpessoal da renda, em nível nacional e por regiões.

${ }^{2}$ A causação circular acumulativa descencente pode, por exemplo, ser gerada pelo fechamento de uma grande fábrica em uma pequena comunidade, o que causa um impacto negativo de monta sobre o emprego, a renda e as finanças públicas locais. A perda de receitas públicas levaria a comunidade a aumentar os impostos, tornando a localidade menos atrativa para as atividades econômicas e desencadeando um processo cumulativo descendente de subdesenvolvimento. Conseqüentemente, os impactos diretos e indiretos sobre o emprego, as atividades interligadas (indústria agricultura, comércio, serviços), as finanças públicas e os fluxos migratórios, em razão dos efeitos multiplicadores, serão maiores do que a redução inicial da atividade. Por sua vez, a causação circular acumulativa ascendente pode, por exemplo, ser fornecida pela instalação de uma grande empresa em uma localidade, exercendo efeitos multiplicadores, diretos e indiretos, sobre o emprego e a produção local, interligados tecnologicamente, ou via demanda final. O aumento das receitas públicas locais levaria à instalação de infra-estruturas e à melhoria dos demais serviços prestados pelo setor público, gerando economias extemas tecnológicas e pecuniárias que atrairiam as atividades econômicas (Myrdal, 1968, p. 43). 
visto que o livre jogo das forças de mercado, principalmente nas "fases" iniciais do desenvolvimento, leva à concentração do crescimento na região central (Souza, 1993a, p.30). Nota-se, portanto, que as desigualdades regionais engendradas "dentro" de um país, também se produzem em nível internacional, certamente por causa das diversidades de vantagens comparativas e velocidades de desenvolvimento que cada país apresenta.

Nesse contexto, criadas as desigualdades inter-regionais em nível nacional ou internacional, de acordo com os níveis de desenvolvimento industrial das regiões, a teoria do crescimento distingue nas relações de troca regionais os chamados efeitos regressivos e propulsores. Os efeitos regressivos derivam, por exemplo, da troca desigual entre as regiões mais ricas, exportadoras de produtos manufaturados, e as mais pobres, especializadas na produção de matérias-primas e alimentos não processados. Esses efeitos regressivos, como produtos do maior dinamismo de crescimento dos centros maiores, criam também, simultaneamente, um processo seletivo de transferência da mão-de-obra e capital, com todas suas seqüelas negativas em detrimento das regiões mais pobres. Geralmente, as regiões desenvolvidas oferecem maiores oportunidades de empregos, taxas de retorno mais elevadas para os investimentos, melhor infra-estrutura de transporte e comunicação, serviços públicos, assistência social acessível, etc. Em contrapartida, os efeitos propulsores, derivados do crescimento do pólo urbanoindustrial, que provocam efeitos de encadeamento no conjunto das regiões do país e entre países, podem, nas regiões menos desenvolvidas, em decorrência de seu dinamismo, aumentar suas exportações de alimentos, matéria-prima, insumos industriais e manufaturas de consumo final para os pólos de crescimento nacionais e

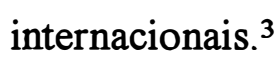

Quando os efeitos regressivos se apresentam maiores do que os efeitos propulsores, obviamente, determinadas regiões tendem a crescer mais lentamente, estabelecendo-se uma convivência "injusta" entre territórios estagnados e territórios

3 No Brasil, alguns exemplos podem ser citados: o estado de Rio Grande do Sul produz peças de reposição para a indústria automobilística paulista; Santa Catarina exporta aves congeladas para o centro do país; a Bahia produz produtos petroquímicos para as regiões Sul e Sudeste, etc. (Souza, 1993a, p. 41). Entre os países da Ásia, por exemplo, a Coréia e Taiwan produzem manufaturas leves para a indústria japonesa e norte-americana (Furukawa, 1986). 
desenvolvidos, isto é, fazendo, segundo Furtado (1961), com que o subdesenvolvimento se torne produto do desenvolvimento. ${ }^{4}$ Esta é a razão pela qual, tanto em países desenvolvidos como nos em desenvolvimento, existe protecionismo em relação às importações de produtos agrícolas e no que concerne às importações de produtos industriais, ou seja, os países, por questões estratégicas, precisam proteger suas regiões ou setores menos desenvolvidos.

Obviamente, para neutralizar os efeitos regressivos e promover o desenvolvimento das regiões menos favorecidas, é necessário intensificar os efeitos propulsores provenientes do pólo urbano-industrial. Pela teoria do crescimento polarizado, isso pode ser feito através da implementação de atividades interdependentes em pólos secundários nas regiões menos desenvolvidas, que servem de pontos de articulação, filtrando e promovendo a integração da hierarquia urbana e industrial, bem como pela neutralização dos efeitos regressivos produzidos pelos oligopólios e unidades dominantes do pólo central.

A criação de infra-estruturas e de pequenos projetos vinculados à agricultura no interior das regiões menos desenvolvidas, assim como de atividades industriais e de serviços em seus centros urbanos, pode contribuir para o aumento dos efeitos propulsores. Nesse sentido, dentre outros, alguns projetos específicos podem ser implementados: a) infra-estrutura para a produção, comercialização e agroindústria junto às zonas produtoras; b) abertura e asfaltamento de estradas secundárias, ligando as áreas agrícolas do interior com a grande malha rodoviária nacional; c) implantação de indústrias, incentivos físcais diversos e gastos públicos diferenciados por setores e regiões nos centros maiores da periferia (Souza, 1993a, p. 43). Toda essa reorientação da estrutura do mercado, associada a um processo de implementação e/ou de

\footnotetext{
${ }^{4} \mathrm{O}$ sul dos Estados Unidos, que se especializou na produção de algodão nos séculos XVII e XIX, esteve estagnado até 1955 e, por assim dizer, subdesenvolvido. O Mississipi, o mais pobre dos estados norteamericanos, que, na década do 1970 , se encontrava em fase de industrialização, adotou políticas no sentido da diversificação de sua base industrial, criando novas indútrias e distribuindo-as uniformemente por todo o estado, com o objetivo de neutralizar os fluxos de migração interestadual dirigida aos maiores centros urbanos (Williamson, 1977, p. 74). Na Itália, a coexistência do norte industrializado e do sul subdesenvolvido (Região do Mezzogiorno) apresentava-se como um problema sério do planejamento regional até há poucos anos. Na França, a Bretanha, até a década de 1970, ainda era uma regiãoproblema (Souza, 1993a, p. 42).
} 
aprimoramento do sistema de comercialização, dependerá, contudo, fundamentalmente, da escolha do tipo de atividade econômica para o desenvolvimento de uma dada região.

O grande problema da neutralização dos efeitos regressivos, em nível nacional ou internacional, diz respeito à possível redução de eficiência da economia: a taxa nacional de crescimento poderá diminuir quando for acelerada a desconcentração da atividade econômica dos pólos principais, na tentativa de redução das desigualdades regionais. Enfim, trata-se do tradicional conflito, nem sempre verdadeiro, entre eficiência e eqüidade: aumenta-se a eficiência, podendo-se reduzir a eqüidade, e viceversa.

Esse, entretanto, não é o único problema das economias com desenvolvimento polarizado e desequilíbrios regionais. Novas questões, pouco exploradas, nascem para a teorização e mensuração quando essas estruturas são confrontadas com as novas tendências da economia internacional, notadas através dos processos de globalização e regionalização.

\subsubsection{A globalização: assimetria e contradição}

A globalização econômica, entendida como uma crescente interdependência entre as distintas nações, por causa da expansão do comércio internacional, do investimento estrangeiro direto e dos fluxos financeiros, com uma taxa de crescimento que supera amplamente a do produto bruto mundial, expressa a conveniência da maior inserção das economias dos países no mercado internacional, ${ }^{5}$ a qual se fundamenta nas potencialidades de competitividade que cada país apresenta.

Nesse sentido, é importante assinalar que os fatores determinantes da estrutura de custos no contexto da globalização são, em geral, atributos construídos (qualificação da mão-de-obra, facilidades de comunicação, facilidades em termos de infra-estrutura, estabilidade macroeconômica e outros) e não estáticos (disponibilidade de recursos naturais, por exemplo), de tal maneira que a estratégia competitiva de cada

\footnotetext{
${ }^{5}$ De fato, os investimentos diretos mundiais cresceram entre 1983 e 1989 a uma taxa três vezes maior que
} as exportações mundiais e quatro vezes superior ao crescimento do PIB mundial (Guerra, 1993). 
país passa a ser a maximização da oferta desses atributos, como forma de atrair e reter o maior volume possível de investimentos estrangeiros (Baumann, 1996). Daí o consenso de que a estratégia exportadora e de abertura econômica, acompanhada da identificação de projetos nacionais e, neles, da necessidade efetiva de recursos externos, é mais favorável para a adoção de tecnologia e, portanto, para o desenvolvimento econômico do que a de um regime comercial orientado exclusivamente para o mercado interno.

No processo de globalização, contudo, apesar de sua natureza abrangente, existe um componente discriminatório em relação aos países em desenvolvimento, cujas caraterísticas podem ser resumidas em dois aspectos. O primeiro é o fato de que dois terços do comércio mundial se concentram atualmente nos Estados Unidos, na Comunidade Econômica Européia e no Japão, bem como de que mais de $80 \%$ do investimento externo direto foi canalizado, a partir da segunda metade da década de 1980, para esses países, o que realça, desde logo, o caráter assimétrico do comércio e dos investimentos em relação aos países menos desenvolvidos. Basta ver, nesse sentido, que os países em desenvolvimento somente receberam $17 \%$ do investimento estrangeiro total, dos quais dois terços foram canalizados para apenas dez países. Segundo, a presença de um significativo aumento de pressões protecionistas de novo tipo por parte dos países desenvolvidos, marcadas, fundamentalmente a partir de 1970, pelo incremento das barreiras não tarifárias, acordos voluntários de exportação, direitos compensatórios, cláusulas anti-dumping, etc., os quais, ao se estenderem para todos seus setores "maduros", como o sidenúrgico, o têxtil e os produtos agrícolas, afetaram especialmente o comércio com os países em desenvolvimento. Tem-se, assim, um fato contraditório com a interdependência comercial que prega a globalização, ${ }^{6}$ visto que existe uma situação de claro contraste entre esse protecionismo e a forte tendência, desde a década de 1980, para a abertura de suas economias por parte dos países em desenvolvimento (Bekerman \& Sirlin, 1996, p. 92-94).

${ }^{6}$ Estimativas indicam que, no ano de $1974,40 \%$ do comércio mundial encontrava-se controlado, ou seja, estava sujeito a alguma forma de restrição não tarifária; já, em 1980 , este controle passou para $48 \%$ (Grimwade, 1989). Nesse mesmo sentido, a Fuia (1994) indica que, na década do 1980, por exemplo, $44 \%$ das ações anti-dumping e $61 \%$ dos direitos compensatórios implementados nos Estados Unidos, na Comunidade Econômica Européia, na Austrália e no Canadá tiveram como objetivo restringir as exportações dos países em desenvolvimento. 
A questão é, portanto, como os países em desenvolvimento deverão enfrentar os problemas de assimetria e contradição que apresenta a globalização econômica mundial?

As posições mais otimistas consideram, em relação ao comércio, que, enquanto não existirem na OMC regras globais de regulamentação mais claras e efetivas contra as pressões protecionistas não tarifárias, a solução do problema está longe de ser definitiva a médio prazo; as posições mais realistas, por sua vez, defendem que não existirá uma solução global nem a longo prazo e que se deverá chegar apenas a soluções parciais.

Quanto ao movimento financeiro, parece razoável pensar que dependerá da capacidade de cada país identificar projetos nacionais que possibilitem a captação de investimentos estrangeiros. Isso para que o acesso ao capital internacional the seja menos exógeno dada a perspectiva assimétrica que apresenta a globalização quanto à alocação de recursos financeiros.

\subsubsection{A regionalização: integração econômica e desigualdade regional}

A retomada da integração econômica por parte dos países em desenvolvimento pode ser interpretada, na atualidade, como uma estratégia defensiva e de desenvolvimento econômico frente ao processo discriminatório que se engendra no processo de globalização. Isso porque, de um lado, a integração assegura em maior dimensão ganhos de competitividade, de escala produtiva e de acesso aos mercados; de outro, cria circunstâncias que permitem aos países integrantes se exporem menos a possíveis conflitos comerciais e terem melhor capacidade de capitalizar o investimento estrangeiro direto.

A integração dos países em desenvolvimento, contudo, encarada como uma estratégia de desenvolvimento econômico, deve ser repensada em relação aos possíveis efeitos benéficos e adversos que provocará nos países e nas regiões de cada país. 
Nesse sentido, um processo de integração econômica regional, qualquer que seja a forma adotada, inicia-se com a implementação de mecanismos destinados a eliminar a discriminação ao comércio intra-regional, enquanto se estabelecem tarifas externas comuns contra terceiros países. ${ }^{7}$ Conseqüentemente, é definido um espaço econômico no qual se torna possível, via fluxos de comércio, o aproveitamento das vantagens comparativas e das economias de escala que um mercado ampliado permite.

A implementação do novo mercado passa, necessariamente, por três grandes e bem definidas etapas: primeira, o estabelecimento de alguma forma aduaneira ou de livre comércio; segunda, a união tributária, que busca harmonizar gradativamente as tarifas internas e externas do comércio; terceira, a formação de um mercado comum que, em sua essência, agrega fluxos livres de fatores de produção à̀ duas etapas anteriores (Lizano, 19.73).

Nesse contexto, acredita-se que o processo de integração é um caminho alternativo para que um país atinja um maior desenvolvimento econômico, o qual, sendo bem-sucedido, proporcionará reais vantagens para todos os países-membros; contudo, isso não assegura, necessariamente, um aumento do bem-estar social mundial.

Teoricamente, do ponto de vista estático, os ajustes econômicos benéficos para a região, derivados de um esquema integracionista, estão associados à criação de comércio, que surge entre os países da união quando uma fonte de abastecimento a custos menores substitui outra menos eficiente. Já os efeitos adversos relacionam-se com o desvio de comércio, que ocorre quando uma fonte de abastecimento internacional a

\footnotetext{
7 Para implementar esquemas de integração econômica, geralmente, são usados diferentes mecanismos tarifários, os quais deram origem às diferentes formas de integração: a Área de Comércio Preferencial, que é a forma mais elementar e imperfeita da integração, caracterizada, basicamente, por reduções nas taxas alfandegárias, formada por uma preferência regional que se outorga aos países nos acordos denominados parciais (Conesa, 1987); a União Econômica, forma distinta do mercado comum, que combina a supressão das restrições ao comércio e aos fatores de produção com um certo grau de harmonização das políticas econômicas nacionais, com o objetivo de eliminar a discriminação resultante da disparidade dessas políticas; a Área de Comércio Livre, que consiste num grupo de países que aboliu todas as barreiras tarifárias entre si, mantendo suas tarifas individuais frente ao mundo exterior; a União Aduaneira, que é diferente de uma área de comércio livre pelo fato de ter uma tarifa extema comum que se aplica às importações do mundo exterior, realizadas por qualquer país-membro; sendo o movimento de mercadorias "dentro" da união livre; por último, o Mercado Comum, que não só permite o livre movimento de produtos como também de todos os fatores de produção; por isso, o mercado comum representa uma forma superior da integração econômica (Anderson, 1986).
} 
custos menores é substituída por uma de custos maiores provenientes da união (Viner, 1950).

Do ponto de vista dinâmico, a integração econômica pode forçar as indústrias tradicionais e conservadoras a adotarem medidas de aperfeiçoamento. Por exemplo, se uma indústria tradicional de um país usa técnicas ultrapassadas e, em outros países, a competição entre este tipo de indústria é intensa e as práticas de produção e comércio são modernas, uma vez implementada a união, aquela terá de se aperfeiçoar em sua estrutura econômica caso deseje permanecer no ramo: Em conseqüência, haverá ganhos tanto na poupança de recursos produtivos quanto na capacidade de gerenciamento empresarial em todos os níveis (Ellsworth, 1978, p. 578).

Simultaneamente, com o incremento das dimensões do mercado através da união, a demanda será maior; assim, se as empresas trabalham sem "capacidade ociosa" ou com pleno emprego, podem expandir o tamanho de suas fábricas de forma mais acelerada, gerando economias de escala (Camoy, 1977). Nesse sentido, quando bem definidas as necessidades do novo mercado, ocorrerão ganhos acelerados no campo da tecnologia e do investimento, tanto para produtos finais como para intermediários, o que não haverá na ausência de integração econômica. Tais efeitos, no mercado dos consumidores, traduzem-se em menores preços e na disponibilidade de diversos produtos no mercado ampliado.

Em resumo, qualquer que seja a natureza dos efeitos estáticos e dinâmicos da integração no tempo, a literatura sugere que ocorrerá, entre as regiões produtoras de matéria-prima e as indústrias existentes, uma redistribuição dos fatores de produção e da tecnologia disponível. Assim, algumas indústrias e regiões produtoras poderão se expandir, outras se contrair, enquanto os consumidores se beneficiarão com preços mais baixos em determinados produtos.

Disso se conclui, segundo Meade (1968) e Andic \& Teitel (1977), que existirão maiores beneficios quando todos os membros tiverem uma estrutura de produção desenvolvida e homogênea em termos de competitividade, mas forem, depois, potencialmente complementares não só no uso de tecnologia como na distribuição espacial de sua indústria. Isso porque, nessas circunstâncias, existem maiores 
probabilidades de suas atividades se tornarem interdependentes ao ponto de seus efeitos de encadeamento provocarem maior dinâmica de crescimento na região.

Essa, naturalmente, é uma experiência teórica, pensada para um grupo de países economicamente avançados, cujo objetivo fundamental centra-se na busca de ganhos de eficiência na produção e no consumo por meio do jogo das forças de mercado. Conseqüentemente, os "custos e beneficios" derivados da integração econômica, teoricamente, seriam distribuídos de "forma eqüitativa", de tal modo que o grupo atingiria desenvolvimento econômico e social em conjunto.

O que acontece, porém, quando se realiza a união de países que possuem marcados desequilíbrios regionais, pela presença significativa de desigualdades em suas estruturas de produção, fruto do crescimento polarizado de suas economias? Mais ainda, o que acontece quando esses países, através da integração econômica, procuram maior abertura do mercado interno, melhor capacidade de negociação com o resto do mundo, menor participação do setor público e, sobretudo, a modernização de suas estruturas produtivas, ou seja, um sistema que permita melhor realocação dos recursos produtivos e práticas de preços satisfatórios ao consumidor?8

Certamente, em razão da falta de evidência empírica sobre esta problemática, muito se pode especular a respeito, até porque não existe um corpo teórico integrado que analise tais aspectos.

Se, por exemplo, nas economias, os efeitos propulsores forem predominantes, espera-se que a ampliação da demanda intra-regional, resultante do incremento do número de consumidores, estimule os fluxos de abastecimento de produtos competitivos e complementares; o mesmo efeito poderá ocorrer pela redução

8 Essa procura no âmbito da integração econômica latino-americana encontra, em geral, sua fundamentação em três aspectos: primeiro, os países, em seu intento de industrializar suas economias. sob uma forte proteção tarifária e de subsídios e, portanto, de sacrifício da renda nacional, desenvolveram alguns setores produtivos de ponta favoráveis à aquisição de tecnologia moderna, atingindo hoje niveis de competitividade internacionais que podem dispensar em parte o protecionismo; segundo, que o sacrifício da renda nacional não se justifica mais em setores produtivos que não obtiveram, durante os últimos 45 anos de proteção tarifána e subsídios, ganhos significativos de eficiência na produção, fundamentalmente pela falta de concorrência do mercado intemo, ou simplesmente pela inexistência de vantagens comparativas (Montoya, 1993, p. 149) e, terceiro, o Estado, no início da pretendida industrialização, foi praticamente obrigado, pelas necessidades 
dos preços via eliminação das tarifas no comércio intra-regional. A interdependência comercial poderá provocar interdependência tecnológica que, por sua vez, gerará a reaglomeração territorial das atividades econômicas. Em virtude dessas interligações insumo-produto, as firmas terão condições concretas de revigorar os complexos industriais, integrando-os aos pólos de crescimento. Por sua vez, os pólos de crescimento, em virtude da distribuição geográfica dos efeitos de encadeamento e da magnitude de abrangência de sua área de influência, poderão provocar efeitos dinâmicos com mudanças estruturais no local onde estão implantados. Através de eixos de desenvolvimento, poderão também ser gerados pólos de integração em regiões-fronteira, que aumentem e consolidem as relações comerciais entre países. ${ }^{9}$

Por outro lado, se, num processo integracionista, os efeitos regressivos forem predominantes, como produto do maior dinamismo de crescimento dos centros maiores, indubitavelmente, as desigualdades regionais irão se aprofundar, com todas suas seqüelas negativas para o bem-estar das populações. Poder-se-á esperar, ainda, uma deterioração dos termos de troca entre os países, entre as regiões de um mesmo país e entre as diversas regiões dos países como um todo, isto é, engendrar-se-á um processo de empobrecimento de regiões menos desenvolvidas que chegará ao ponto de inviabilizar o próprio processo de integração econômica.

Enfim, essas especulações extremas, num contexto de desenvolvimento polarizado, desequilíbrios regionais e integração econômica, ilustram quão premente é a necessidade de se desenvolverem pesquisas nessa área para que melhor se compreendam os impactos econômico-sociais nos países em desenvolvimento. Tal é o caso dos países do Mercosul.

econômicas e forças políticas, a incorporar uma infra-estrutura tal que, nos tempos atuais, é onerosa ao ponto de desequilibrar as contas nacionais, sendo seu enxugamento um fato premente.

${ }^{9}$ Um pólo de crescimento é um complexo industrial localizado, formado por atividades interdependentes, que possui em seu meio, no mínimo, uma indústria motriz. Um eixo de desenvolvimento constitui-se por uma via de transporte e por centros de crescimento com infra-estruturas para atividades industriais e de prestação de serviços. Um pólo de integração é um pólo de crescimento localizado em uma região- 


\subsection{Mercosul: problema de pesquisa e sua justificativa}

O marco conceitual no processo do Mercosul, assim como os demais esquemas sub-regionais de integração da América Latina, atualmente está direcionado por uma filosofia diferente da que impulsionou os diversos projetos de integração no passado. De um conceito integracionista de caráter autárquico, com base numa forte proteção frente a terceiros países e com uma lenta e dificil eliminação recíproca de tarifas, passou-se a um esquema acelerado de integração que objetiva a implementação de um mercado comum.

Nessa dinâmica, as negociações entre Argentina, Brasil, Paraguai, Uruguai e, nos últimos tempos, Bolívia e Chile, com base no tratado de março de 1991, para a construção de um mercado comum, têm sido qualificadas como um ato político da maior importância, porquanto abrem amplas possibilidades de cooperação e articulação de políticas macroeconômicas e setoriais na busca do desenvolvimento econômico conjunto entre os países.

Embora não se conte com muito suporte em matéria de mensuração dos efeitos de um mercado comum para a construção de políticas macroeconômicas e setoriais, uma vez que não existe um corpo de pesquisas integrado, surgem as mais diversas reações, preocupações e esperanças sobre os seus efeitos, benéficos e adversos, na opinião pública, nos setores político, técnico e acadêmico.

No âmbito das esperanças benéficas, acredita-se que o novo mercado, para muitos setores produtivos, representará a troca do conforto propiciado por um mercado protecionista pelos riscos e vantagens existentes numa economia de mercado aberto. Isso porque a abertura de mercados promove novas concorrências que, inevitavelmente, provocam a necessidade de gestões mais eficientes não só da estrutura produtiva, mas também do consumo nacional. Em conseqüência, espera-se, nas economias dos países do Mercosul, uma realocação das atividades produtivas não só em função do aproveitamento das vantagens comparativas e economias de escala que o (Souza, 1993a, p. 37). 
mercado ampliado permite, mas também em razão da eficiência na produção, no sistema de comercialização e na localização geográfica dos mercados consumidores.

Do ponto de vista das preocupações com os efeitos adversos, talvez as mais destacadas sejam aquelas vinculadas aos desequilíbrios regionais e às desigualdades de desenvolvimento das estruturas de produção que existem entre os países do Mercosul e que coexistem nas diferentes regiões no interior de cada país. Nesse sentido, segundo Maldonado (1986), a experiência integracionista latinoamericana tem demonstrado que, quando as desigualdades das estruturas produtivas são importantes, tende a existir má distribuição dos "custos e beneficios" entre os países da região. Assim, por causa das questões econômicas, da pressão política interna e, conseqüentemente, da falta de maior participação dos agentes econômicos no processo, os países inviabilizam a unificação de seus mercados pelo não-cumprimento das obrigações de reciprocidade comercial.

Mesmo sendo evidentes as disparidades regionais e os problemas que implicam, é comum, no entanto, perceber uma acentuada insistência em integrar as economias dos países somente com a liberalização do comércio inter-regional, acreditando-se erroneamente que, com isso, as desigualdades econômicas existentes simplesmente serão superadas com tratamentos diferenciados do comércio em favor dos países que apresentam uma balança comercial deficitária. Isto é, os mecanismos de integração objetivam mais amenizar o sentido do comércio do que solucionar as disparidades regionais (Montoya \& Chaminade, 1994).

Não se questiona, por exemplo, qual é o nível de integração econômica e de articulação industrial existente entre as regiões de um determinado país, ou seja, não no que se refere à liberdade de circulação de mercadorias e fatores de produção que procuram os blocos regionais, mas, sim, no que diz respeito à "igualdade de oportunidades" das regiões de um país para que possam participar do desenvolvimento econômico nacional. Em razão disso, discute-se sua capacidade nacional de integração com outros países, de forma que a maioria dos setores produtivos de um país participe ativamente do novo mercado. 
Esse enfoque alternativo torna-se importante porque salienta que a acentuada desarticulação industrial existente "dentro" de um país pode ser visualizada como um processo de desintegração econômica, já que indústrias desarticuladas implicam ligações interindustriais fracas, desemprego, limitada capacidade de resposta às políticas de desenvolvimento, mercados restritos, fragilidade das economias frente a mudanças no mercado internacional, etc. Assim, as conseqüências desse processo, em nível nacional e internacional, comumente manifestam-se pela contínua transferência seletiva de capital de regiões menos desenvolvidas em favor de regiões-pólo mais desenvolvidas, o que, em casos extremos, provoca transtornos negativos para a comunidade, como acentuação das desigualdades entre os países e as regiões de cada país, desequilíbrio, desorganização, desajuste e crise econômica.

Frente a esse panorama, parece que a formação do novo mercado, produto de um processo de integração econômica entre países com características de crescimento polarizado, como é o caso dos países do Mercosul, poderá ser dinamizada fundamentalmente, em nível nacional, pelas regiões-pólo centrais de crescimento e, em nível internacional, pelos países que detêm as indústrias melhor articuladas. Assim, a integração econômica dos países com base num mercado comum poderá se dar em nível de regiões e países mais desenvolvidos e, em menor dimensão, nas regiões e países menos desenvolvidos.

Nos moldes do Mercosul, a integração econômica será factível somente com a participação substancial dos pólos centrais de crescimento nacionais e, em decorrêcia, pelas economias mais industrializadas? Qual será o nível de participação das regiões menos desenvolvidas no processo de integração econômica nos moldes de um mercado comum? Com a integração econômica, estimular-se-ão as economias para um crescimento mais polarizado ou mais desconcentrado? Serão as regiões menos desenvolvidas simplesmente corredores de passagem de mercadorias e fatores de produção entre os pólos de crescimento nacionais ou deverão elas participar ativamente da nova dimensão do mercado integrado? Se for maior a participação, qual deverá ser a estratégia básica no contexto do Mercosul para que as regiões menos desenvolvidas 
tenham maior participação ao lado das regiões-pólo centrais, de tal forma que uma fortaleça a outra?

Para dar resposta a essas questões, os diversos tratados que formaram a Associação Latino-Americana de Livre Comércio (Alalc) em 1960, a Associação Latino-Americana de Integração (Aladi) em 1980, o Grupo Andino (Gran) em 1969 e o Mercado Comum do Sul (Mercosul) em 1991 comumente contemplam a criação de uma estrutura de órgãos executivos que tomem providências e medidas concretas tendentes à aplicação do Programa de Liberação Comercial, à coordenação de políticas macroeconômicas, à negociação de acordos frente a terceiros países e de programas de trabalho que assegurem avanços para o estabelecimento da integração econômica regional. Porém, essas estruturas orgânicas encontram sérias limitações para estabelecer políticas bem-sucedidas, uma vez que não contam com um instrumental analítico sistêmico em matéria de medição dos efeitos de encadeamento entre os países e nas diferentes regiões de cada país, ou seja, não conseguem, através de um enfoque intersetorial, identificar, por exemplo, quais são as vantagens da integração econômica entre países para uma maior articulação das indústrias de cada país. $\mathrm{Na}$ verdade, os instrumentos de previsão comumente usados limitam-se à análise de um produto ou de um pequeno grupo de produtos quanto ao sentido do comércio e à alocação de recursos de acordo com sua competitividade ${ }^{10}$.

Nesse contexto, como primeiro passo para a discussão dessa ampla problemática, acredita-se ser importante estabelecer um instrumental analítico de equilíbrio geral que permita visualizar, entre os países-membros do Mercosul, as relações intersetoriais insumo-produto que se estabelecem com o comércio internacional. Essa abordagem se justifica na medida em que permite identificar de forma sistêmica os possíveis efeitos da maior interdependência comercial, bem como de políticas econômicas tendentes a harmonizar os fluxos de mercadorias e fatores de

10 Nessa linha de análise, alguns estudos relevantes têm implementado modelos espaciais de equilíbrio parcial de produtos, a fim de encontrar a alocação ótima de recursos em diferentes setores dos países do Mercosul. Por exemplo, o trabalho de Gutierres (1988) aborda a competitividade na produção de grãos entre Argentina e o Brasil; Stein (1991) confronta a produção vitivinicultora do RS e da Argentina; Vilwock (1993) analisa as cadeias de produção de trigo, soja, milho, suínos e aves, e Waquil (1995) estabelece a realocação ótima da produção animal e de grãos no setor agricultura do Mercosul. 
produção. Portanto, esta pesquisa objetiva o fornecimento de subsídios para que melhor se entendam as desigualdades regionais dentro de um processo de integração econômica, em particular no que diz respeito à mensuração dos efeitos de encadeamento entre as diferentes indústrias dos países-membros do Mercosul.

\subsection{Hipóteses}

No processo de implementação do Mercosul, os setores vinculados às economias que apresentam melhor articulação de suas indústrias possuem maior poder de encadeamento inter-regional para promover o crescimento econômico e maior interdependência comercial na região. Se essa hipótese for confirmada, as políticas que procuram incentivar o comércio inter-regional de forma harmônica serão altamente eficientes, porque induzirão o crescimento da produção, do valor adicionado e, em conseqüência, do próprio comércio internacional das economias do Mercosul, ou seja, uma melhor articulação das indústrias nacionais.

\subsection{Objetivos principais}

Descrever e analisar, em termos histórico-econômicos, os principais fatos que deram origem aos processos de integração econômica na América Latina e inferir como as desigualdades de desenvolvimento econômico dos países influenciaram no decorrer de sua implementação.

Com base num arcabouço teórico de equilíbrio geral, identificar, construir e implementar, para o ano de 1990, um modelo de insumo-produto internacional para o Mercosul.

Considerando o Mercosul como um só espaço econômico, identificar e avaliar a importância relativa das relações interindustriais, os setoreschave e a capacidade de indução das demandas finais sobre o crescimento 
econômico dos países da região, de forma a buscar um melhor entendimento da integração econômica entre países com desenvolvimento econômico heterogêneo.

\subsection{Organização da pesquisa}

No capítulo 3, chama-se a atenção, através de alguns fatos mais evidentes, que a experiência integracionista do continente possui uma tradição de mais de um século e salienta-se que as negociações no Mercosul vão muito além dos recentes acordos políticos de sua criação. Para tanto, resgatam-se os antecedentes da integração na região, desde a busca de uma identidade política até, nos últimos anos, a se constituir numa exigência da globalização econômica mundial. Salientam-se ainda quais são os novos desafios para a integração econômica regional e a necessidade de desenvolver um instrumental de análise sistêmico, o qual se propõe seja de equilíbrio geral e do tipo insumo-produto.

No capítulo 4, implementa-se um arcabouço teórico dos modelos de insumo-produto de equilíbrio geral. Para isso, primeiramente, apresenta-se a teoria básica dos modelos de insumo-produto; em seguida, estabelece-se uma classificação dos modelos inter-regionais e, por extensão, internacionais, a qual leva em consideração a natureza das informações estatísticas utilizadas e os métodos de estimação das matrizes; finalmente, discutem-se os alcances e as limitações dos principais modelos.

O capítulo 5 descreve a metodologia de construção e compilação do modelo insumo-produto internacional proposto para o Mercosul. As considerações metodológicas referem-se, além do processo de construção da matriz, à forma alternativa de estimar os coeficientes técnicos de abastecimento internacional. Discute-se também a qualidade dos dados disponíveis, citando-se algumas de suas limitações e descrevendose o tratamento implementado para sua utilização.

O capítulo 6 propõe-se a caracterizar o perfil das transações internacionais no Mercosul, comparando a dimensão econômica dos países e estabelecendo os níveis de integração espacial dos mercados. Efetua-se também a 
mensuração das ligações intersetoriais a fim de identificar setores-chave, sendo eles determinados por mais de um método de estimação. Dessa forma, torna-se possível avaliar e discutir por meio de que setores se pode promover maiores níveis de integração econômica na região.

O capítulo 7 propõe-se a estabelecer o grau de influência do comércio internacional sobre as economias do Mercosul. A sua primeira parte dedica-se a identificar e avaliar, em termos relativos, os fluxos de comércio que são relevantes na produção induzida agregada e setorial de cada país; a segunda destaca a capacidade de as demandas finais de cada país induzirem valor adicionado no próprio país e nos países parceiros e, ainda, a possível tendência do comércio inter-regional nos próximos anos; por último, na terceira parte, procura-se avaliar a composição das importações e exportações inter-regionais induzidas na região.

Finalizando, apresentam-se as principais conclusões obtidas ao longo da tese. 


\section{A INTEGRAÇÃO ECONÔMICA, OS NOVOS DESAFIOS E A NECESSIDADE DE UM INSTRUMENTAL DE ANÁLISE SISTÊMICO NA REGIÃO}

Comumente, a integração econômica na América Latina é tratada como um fato isolado e recente. Contrariando tal enfoque, este capítulo tem como objetivo chamar a atenção, através de alguns fatos mais relevantes, que a experiência integracionista no continente posșui uma tradição de mais de um século, seja como um movimento social na busca de afirmação de sua cultura, seja como uma estratégia de desenvolvimento econômico ou, nos últimos tempos, como uma exigência da globalização econômica mundial.

Nesse sentido, sabendo-se que as negociações do Mercosul vão muito além dos recentes acordos políticos de sua criação, já que ele representa um subgrupo de integração "dentro" da Aladi, acredita-se ser importante para a comprensão de seu processo uma análise da experiência integracionista no continente. Com essa perspectiva, discutem-se: a) os antecedentes da integração na região, desde a busca de uma identidade política até a política Cepalina de desenvolvimento; b) as experiências mais importantes das décadas de 1960 a 1980, bem como a influência do liberalismo econômico da década de 1990 e, por fim, c) os novos desafios impostos e a necessidade de um instrumental de análise sistêmico para a integração da região.

\subsection{Antecedentes da integração na América Latina: da busca de identidade política a uma política alternativa de desenvolvimento}

As primeiras idéias integracionistas na América Latina nasceram no século XVIII, durante a fase de luta pela independência política. Simón Bolívar (1783- 
1830), um dos principais defensores dessas idéias, não poupou esforços para que fosse assinado o Tratado de União, Liga e Confederação Perpétua em 26 de julho de 1826, visando à união das Repúblicas da Colômbia, Centro América, Peru, Estados Unidos e México, e pela Organização da Grã-Colômbia, para unir em uma só República os territórios da Colômbia, da Venezuela, do Equador e do Peru (Silva, 1990, p. 34). Tudo isso porque havia a forte convicção na época de que não existiria independência política segura no Novo Mundo sem uma confederação que a sustentasse (Ezcurra, 1988). Sobre a unidade política, Bolívar" afirmava: "era uma idéia grandiosa pretender formar de toda América hispânica e portuguesa por extensão uma só nação, com um só vínculo que ligasse suas partes entre si e com o todo... Já que tem uma origem, uma língua, os mesmos costumes e uma religião, deveria, por conseguinte, ter um só governo que confederasse os diferentes Estados que venham a formar-se" ${ }^{12}$.

Esses ideais integracionistas, porém, passaram a um segundo plano porque tanto a Inglaterra como os Estados Unidos, em sua luta pela hegemonia na região, patrocinaram a divisão da América Latina. Isso foi feito através de conflitos bélicos $^{13}$ ou, no mínimo, diplomáticos, no século XIX, até as décadas de 1920 e 1930, quando a hegemonia norte-americana, com a "política de boa vizinhança" de Roosevelt, predominou (Praxedes, \& Piletti, 1996, p.100-119).

Cabe salientar, contudo, que, apesar da hegemonia dos Estados Unidos, os ideais pela unidade latino-americana, iniciada por Bolívar, não sucumbiram. Na verdade, suas características de luta mudaram: primeiramente, de um confronto armado contra o colonialismo espanhol e português para uma corrente de resistência políticoeconômica em relação aos Estados Unidos, nas décadas de 1910 até 1960; depois, como

${ }^{11}$ Também conhecido como "O Libertador", por sua liderança na luta pela independência da Venezuela, Colômbia, Equador e Peru; seu nome era José Antonio de la Santisima Trinidade Bolívar y Palácios.

${ }^{12}$. Estas idéias, inicialmente, foram publicadas em Londres, na edição do dia 5 de setembro de 1810 do jornal The Morning Chronide, mas foram melhor explicadas e sistematizadas na famosa e extensa carta escrita na Jamaica, em 6 de setembro de 1915.

${ }^{13}$ A balcanização da América Central e do Caribe, dividida em pequenas nações, completou-se com a separação da Guatemala do México (com quem se articulara na fase colonial); a separação do Panamá da Colômbia; a divisão dos países andinos (antes unidos pelo Império Inca e pela política colonial); a expulsão e desintegração das missões jesuíticas e das províncias cisplatinas, unidas pela Bacia do Prata e pelas tradições gaúchas (Santos, 1993, p.110) e, finalmente, com o conflito armado da Argentina, 
uma forma de afirmação de uma cultura latino-americana ${ }^{14}$ e, nos últimos tempos, como uma estratégia de desenvolvimento por meio da integração econômica dè seus mercados.

A primeira proposta integracionista de caráter econômico na América Latina, embora tenha sido formulada na década de 1950, resulta de processos e constatações mais antigas, dentre as quais se destaca duas: a) a idéia de que a maior concentração demográfica do setor urbano propiciava condições naturais de escala para o desenvolvimento de uma indústria crescente no continente; b) a influência da percepção de Prebisch (1950), que, ao analisar a evolução dos preços dos produtos agrícolas e industriais num período de 65 anos (1880-1945), observou que existia uma clara tendência para a deterioração das relações de troca nos países subdesenvolvidos, ou seja, a relação preço-agricultura e preço-indústria, que era igual a 1 em 1850, caiu tendencialmente para 0,687 em 1945.

Com base nesse fato, alguns economistas latino-americanos ${ }^{15}$ argumentavam que os principais problemas socioeconômicos da região tenderiam a se agravar pela queda do poder de compra de suas exportações, predominantemente as originárias do setor primário. Argumentavam, ainda, que a deterioração das relações de troca nos países exportadores de produtos primários e a conseqüente impossibilidade de transferência dos ganhos do progresso técnico para a periferia deveriam ser neutralizadas através da industrialização de suas economias, via políticas de substituição de importações, como a única forma de desenvolvimento para países subdesenvolvidos. ${ }^{16}$

Brasil e Uruguai contra o Paraguai, que terminou a guerra quase totalmente destruido, tendo perdido três em cada quatro dos seus habitantes. (Praxedes, \& Piletti, 1996, p. 31).

${ }^{14}$ Isso fica evidente quando analisados os movimentos sociais liderados pelos liberais mais radicais, como Juárez, Eugênio, Maria de Hostos, Marti, Sandino e outros, que se consolidaram no pensamento populista latino-americano de Vargas, Perón, Cárbenas, ou assurniram expressões mais radicais, como o primeiro APRA de Haya de la Torre ou o socialismo chileno, afirmando-se, finalmente, no pensamento de uma tradição comunista que viera desde Mello e Mariategui (Santos, 1993, p. 121-122). Entretanto, os que mais se destacaram na elaboração de "programas de união político-cultural latinoamericana", pela repercussão de suas obras e pelo trabalho intemacional desenvolvido, foram o argentino Domingo Faustino Sarmento, o chileno Andrés Bello, o peruano Victor Raul Haya de la Torre, o mexicano José Vasconcelos e o uruguaio José Henrique Redo (Silva, 1990, p. 35).

15 Os economistas, fundamentalmente, compartilhavam das idéias da Comissão Econômica para a América Latina (Cepal), criada em 1947 como órgão organizador e de assessoria econômica no interior da Organização das Nações Unidas (ONU), que, prontamente, dentro do pensamento econômico gerariam a Escola Estruturalista ou da Cepal.

${ }^{16}$ Sob a teoria das vantagens comparativas de David Ricardo, manifestava-se que os países deveriam especializar-se naqueles produtos para os quais apresentassem vantagens comparativas de custos. Desse 
A constatação de um setor urbano crescente e a repercussão dos argumentos de Prebish foram tais que muitos países no continente, incorporando a nova postura teórica sobre os problemas ligados à situação de subdesenvolvimento da região, embarcaram na reestruturação de sua produção nacional através da industrialização acelerada de suas economias ${ }^{17}$, sempre com assessoria da $\mathrm{Cepal}^{18}$.

Por conseqüência, à medida que se intensificaram os meios de sustentação das indústrias (fundamentalmente, na Argentina, Brasil e México) e com o setor primário exportador em alta, a taxa média acumulada de crescimento do produto per capita chegou a $2,7 \%$ a.a. e a 3,3\% a.a. da renda per capita no período $1945-55$, taxas essas relativamente altas para a América Latina. Contudo, apesar desse sucesso, o modelo de industrialização enfrentava seu primeiro impasse entre $1955-5 \dot{8}$, com as taxas de crescimento, tanto do produto acumulado como da renda per capita, caindo para $1,1 \%$ e 0,5\%, respectivamente (Cepal, 1990, p.142). Desse modo, o continente, que tinha encontrado circunstâncias propícias à implementação do modelo de industrialização, começava a apresentar indícios recessivos em sua economia.

Argumentava-se, na época, que esses indícios de recessão estariam relacionados ao problema de insuficiência da demanda interna, que, por sua vez, limitava a adoção de tecnologias produtivas mais eficientes, capazes de gerar economias de escala. Considerava-se, assim, muito restrito o mercado interno para uma

modo, a América Latina produziria alimentos e matérias-primas para a exportação e importaria produtos manufaturados. A idéia era de que o processo técnico gerado nos países desenvolvidos (centrais), incorporado nas importações, difundir-se-ia nos países subdesenvolvidos (periféricos) através da redução dos preços dos produtos manufaturados importados. Ao mesmo tempo, a maior incorporação de tecnologia na produção primária e a maior demanda dos países centrais, em virtude do crescimento de sua renda, elevariam o preço dos produtos primários. As relações de troca melhorariam em beneficio dos países exportadores de produtos não industrializados. Desse modo, os países periféricos não precisariam industrializar-se para atingir o desenvolvimento (Souza, 1993 b).

17 Entre outras coisas, porque observavam em suas economias um aumento relativo maior da taxa de crescimento populacional em relação à taxa de progresso técnico, bem como o fenômeno migratório do campo para a cidade, frente à insuficiência do setor exportador para compensar o excesso de mão-deobra e os desequilíbrios do avanço tecnológico (Cepal, 1951).

18 Já na época, a Cepal tinha conquistado seu espaço no continente ao apoiar os governos populistas, como Perón na Argentina, Vargas no Brasil e os vários presidentes mexicanos do período. Na década de 1950, a Cepal assessorou o govemo revolucionário da Bolívia, que chegou ao poder em 1952, além de suas idéias terem tido uma influência decisiva no governo de Alibenz na Guatemala. Em fins da década de 1950, a Cepal constituía-se num órgão extremamente influente na maioria dos países latinoamericanos (Praxedes, \& Piletti, 1996, p. 120-121). 
industrialização de maior envergadura, ficando evidente a necessidade de maior ampliação do mercado interno (Tussie, 1981).

A saída para esse problema, afirmava a Cepal, era a reformulação do mercado interno, com a implementação de certas mudanças estruturais que facilitassem seu desenvolvimento, como a reforma agrária, melhor distribuição de renda, democratização do crédito, etc. Como tais reformas não tinham sustentação política, os esforços para solucionar a insuficiência da demanda interna, de 1955 a 1960, foram canalizados para duas políticas básicas: a) em nível nacional, na implementação de um conjunto de objetivos setoriais que priorizassem a integração vertical da indústria, o capital social básico e a continuidade da substituição de importações. Em conseqüência, os países em geral, em alguns casos com sucesso e em outros não, criaram mecanismos destinados ao tratamento favorável à entrada de capital estrangeiro e incentivos cambiais e creditícios para o investimento direto. O setor público, por sua parte, deveria encarregar-se da implementação de uma infra-estrutura de serviços públicos e financiamento dos investimentos industriais, estabelecendo algum tipo de reserva de mercado conveniente que incentivasse o investimento privado na diversificação industrial $^{19}$; b) em nivel de continente, dado que os indícios recessivos eram causados pela falta de demanda e sabendo-se que o primeiro impacto de um processo de integração econômica regional é o seu incremento, outra solução ao problema que se mostrava plausível e complementar às políticas industrializantes de cada país era a integração econômica da América Latina. Portanto, a integração apresentava-se como uma condição para a industrialização e esta, por sua vez, além de justificá-la, era sua mais importante motivação.

Em síntese, colocam-se duas questões básicas para a compreensão da proposta integracionista na América Latina: primeiro, a ênfase em acelerar a industrialização com base na tese de que, sem ela, o desenvolvimento econômico seria impossível e, segundo, a condição de que os problemas básicos da industrialização na

\footnotetext{
${ }^{19}$ Por exemplo, no Brasil, o Plano de Metas (1956-1960) objetivava esse tipo de atividades; na Argentina, o Plano Qüinqüenal de Perón.
} 
região estariam atrelados às limitações dos mercados nacionais a que as indústrias estão circunscritas.

\subsection{A experiência das décadas de 1960 e 1970: a atuação da Alalc e as inovações do Grupo Andino}

Objetivando promover a integração regional e avançar nas primeiras definições de uma fórmula que concretizasse esse processo, a Secretaria Executiva da Cepal criou, em 1957, o Grupo de Trabalho de Mercado Regional Latino-Americano e o Comitê de Comércio, o que resultou no documento intitulado $O$ Mercado Comum Latino-Americano, publicado em junho de 1959, que tinha por fim apoiar as negociações para a formação da Associação Latino-Americana de Livre Comércio (Alalc) em $1960^{20}$. Esta instituição tinha como objetivo gerar um processo de integração econômica no continente nos moldes de um mercado comum. Seus países-membros, em 1960, eram Argentina, Brasil, Uruguai, Chile, México, Paraguai, Peru e Uruguai; em 1961, nela ingressaram Colômbia e Equador; Venezuela, em 1966 e Bolívia, em 1967.

Com a abertura do mercado em nível regional, a Cepal e todos os países que aderiram à integração regional reconheciam que as facilidades criadas em cada país pela política de substituição de importações não tinham dado lugar a iniciativas significativas em matéria de exportações industriais para o restante do mundo. Mais ainda, o exagero das políticas protecionistas contra as importações, em muitos casos: tinha anulado a atmosfera de competitividade no mercado interno. Assim, com : eliminação de restrições ao comércio inter-regional, acreditava-se que se restabeleceria c espírito da competitividade, com notórias vantagens para a política de industrialização ${ }^{21}$.

\footnotetext{
${ }^{20} \mathrm{~A}$ esta altura, fica evidente que foi a Comissão Econômica para a América Latina (Cepal ) talvez : primeira instância formal e em nivel governamental com que o subcontinente contou para a sua atuaçã conjunta. Segundo Santos (1993, p. 120), até o pós-guerra, havia poucos instrumentos diplomático para uma atuação conjunta e funcional na região.

21 No documento O Mercado Comum Latino-Americano, de julho de 1959, publicado pela Cepa] manifesta-se claramente a necessidade de maior abertura dos mercados em nível regional par neutralizar o exacerbado protecionismo que os países, em seu empenho de industrializaçãc implementaram.
} 
O tratado estabeleceu a liberalização do comércio na região num prazo de transição de 12 anos, ou seja, até 1973 (que logo foi prolongado por mais oito anos, até 1980), para que se estabelecesse uma área de livre comércio pela redução de tarifas, eliminação de barreiras comerciais em praticamente todo o comércio existente e a unificação de suas tarifas em relação ao restante do mundo, como o fazem os participantes das uniões aduaneiras ${ }^{22}$.

A Alalc desenvolveu-se bastante no início já que conseguiu reverter a tendência declinante que registrava o comércio intra-regional, fazendo com que as exportações regionais quase dobrassem de 1961 a 1964, passando de 490 para 835 milhões de dólares (Sandroni, 1994, p. 12). Contudo, a década de 1970 mostrou o seu fracasso.

A participação relativa do comércio intra-regional sobre as exportações totais da Alalc cresceu em torno de $8 \%$ entre $1960-64 ; 11,4 \%$ até $1971-72$ e $13,8 \%$ até 1979-80, o que supõe um aumento proporcional do comércio intra-regional em relação às exportações totais de $29,8 \%$ no período $1960-72$ e de $17,4 \%$ para o período $1972-80$.

A tendência dos dados mostra, assim, que o crescimento do comércio intra-regional dos primeiros anos, 1960-72, não pôde ser sustentado entre 1972-80 por causa da desaceleração das transações comerciais na região. Verifica-se também que, de 1960 a 1970, foram aprovadas quase nove mil concessões tarifárias contra somente duas mil novas entre 1970 e 1980, fato que é notório na desaceleração do fluxo comercial desta década (Sandroni, 1994, p. 12).

${ }^{22}$ O Mecanismo de liberação do Comércio básico da Alalc, ou denominado também Programa de Liberação, era do tipo multilateral, sendo as negociações efetuadas produto por produto; cada paísmembro oferecia concessões tarifárias sobre a base de uma lista nacional. Os países-membros da Alalc comprometeram-se, inicialmente, a efetuar, na área de integração, reduções tarifárias de $8 \%$ a.a., o que, no entanto, logo foi modificado para $2.9 \%$ a.a. Ademais, das listas nacionais, a Alalc dispôs a confecção de uma lista comum para a qual todos os membros eliminariam totalmente as tarifas e barreiras comerciais até o final do periodo de transição para a área de livre comércio (inicialmente, 1972 e, depois, 1980). As negociações para estabelecer a lista comum se realizavam a cada três anos, estando previsto que, até fins do período de transição, ela contemplaria pelo menos $75 \%$ do valor do comércio intra-regional. Na verdade, os progressos obtidos na confecção da lista comum foram insuficientes para alcançar essas metas, porque era necessário um total acordo multilateral sobre cada produto, bem como pelo fato de ter que incluir produtos agrícolas considerados pelos países como críticos para a produção nacional, o que criou empecilhos insuperáveis nas negociações comerciais (Conesa, 1980). Desse modo, na prática, as listas nacionais constituíram-se no mecanismo efetivo da liberação comercial da associação. 
As negociações comerciais foram tão pouco frutíferas que em torno de $72 \%$ de todas as concessões outorgadas no período $1970-80$ já tinham sido concedidas nos primeiros quatro anos de negociações da Alalc. Desse modo, do universo de produtos contemplados para a liberação comercial ${ }^{23}$, somente $10 \%$ foram atingidos no transcurso de vinte anos de negociações, o que ilustra, claramente, o fracasso da Alalc (Cline, 1990, p. 349).

As causas da crise que ocasionou a desaceleração do processo de liberação comercial da Alalc nunca chegaram a ser exatamente definidas. Uma das explicações levantadas na literatura salienta que existia na Alalc um processo contraditório entre o impulso para a implementação via liberação do comércio interregional e a lógica protecionista do modelo de substituição de importações, com a qual os governos estavam acostumados a encarar a reserva e a proteção do mercado como estimulos ao crescimento, insistindo, por isso, em apresentar extensas listas de exceção nos programas de liberação comercial (Pereira, 1997, p.13-14). Outra explicações diz respeito à desigualdade de desenvolvimento econômico entre os membros da organização, isto é, os mais pobres não teriam condições de participar das negociações da Lista comum e da Lista nacional da mesma forma que os outros, dado que a rigidez do multilateralismo exigia que qualquer beneficio que dois ou mais países se concedessem deveria ser estendido aos demais membros da organização. Assim, pela ausência de mecanismos compensatórios de comércio na Alalc, os países menos desenvolvidos inviabilizaram a unificação de seus mercados quando observaram um saldo deficitário permanente na balança comercial, o que fizeram através do nãocumprimento das obrigações de reciprocidade comercial que o tratado exigia (Maldonado, 1986) e (Montoya, 1993).

Com base nesse argumento e acreditando que existia outro modelo de integração mais adequado às diferenças de desenvolvimento entre os países, em 1969, a Bolívia, a Colômbia, o Chile (que se separou em 1977), o Equador, o Peru e a Venezuela

${ }^{23}$ Os produtos correspondem às linhas tarifárias da Nabalalc, que era a nomenclatura comercial adotada pela Alalc, baseada na nomenclatura tarifária intemacional de Bruxelas. 
formaram o Grupo Andino cujo objetivo, em bases mais restritas e homogêneas que a Alalc, era melhorar a cooperação entre países da região andina.

O mecanismo comercial inovador da integração andina se assenta no princípio da redução tarifária automática de caráter irrevogável, flexível e seletivo, que corresponde à universalidade dos produtos negociados ${ }^{24}$, ou seja, abandonam-se as negociações produto por produto da Alalc e opta-se por um sistema mais acelerado de liberação comercial automática, que pretende obedecer à coordenação de uma política econômica global. Como resultado, e apesar das dificultades que levaram à implementação do Grupo Andino numa época de instabilidade econômica, especialmente na década de 1970, o comércio inter-regional foi multiplicado por dez (Sandroni, 1994, p. 156), além de ter sido criado um programa para desenvolver os setores metal-mecânico, petroquímico, automotriz e siderúrgico (Intal, 1981).

Apesar da expansão comercial acelerada, os países andinos estabeleceram uma lista de exceções que incluía um numeroso grupo de produtos. Do total de 3,322 tipos de produtos compreendidos nas linhas de negociação comercial da região estabelecidas com base na Nabandina, até 1980, mais de 920 continuaram fazendo parte dessa lista para que não fossem afetados pelas reduções tarifárias automáticas (Intal, 1981, P.80-81). Conseqüentemente, não pôde ser consolidada a integração sub-regional, apesar de ainda hoje os países continuarem insistindo nesse processo. Na década de 1980, contudo, ficou evidente que, para que se chegasse a um processo de integração econômica mais profundo no decênio de 1990, os próximos passos deveriam estar direcionados a uma reformulação de seus planos e metas de integração no tempo ${ }^{25}$.

\footnotetext{
${ }^{24}$ Para eliminar as restrições do comércio intemacional, estabeleceu-se que as tarifas deveriam diminuir automaticamente $7 \%$ ao ano a partir do nível tarifário inicial, com o fim de, em 1983, ser alcançada a eliminação total de tarifas na Colômbia, Peru e Venezuela; nos casos da Bolívia e Equador, nos mesmos termos, a redução deveria começar em 1981 e terminar em 1990 (Junta del Acuerdo de Cartagena, 1971). Simultaneamente, foram incluidas também negociações para fixar uma tarifa externa comum, mas sem muito sucesso. Dentre as reduções tarifárias automáticas, são aplicadas reduções tarifárias lineares que consistem na eliminação de tarifas em uma proporção uniforme, por exemplo, em $50 \%$, ou seja, uma tarifa qualquer que, inicialmente, era de $40 \%$, reduzia-se para $20 \%$ e, logo, para $10 \%$ e reduções tarifárias de harmonização, em que as tarifas mais elevadas são diminuídas em uma proporção maior que as mais baixas, objetivando a eliminação das disparidades nas estruturas tarifárias dos países (Grupo andino, 1978).

${ }^{25}$ Em 1988, com base no Protocolo Modificatório de Quito, deram-se os primeiros passos para a reformulação do Grupo Andino. Estes consistiam no aprofundamento das negociações bilaterais, na
} 
Apesar desses problemas, o Grupo Andino posșui o mérito de abandonar uma integração estritamente comercial e tentar, ainda que sem muito êxito, estabelecer um conjunto de medidas que permitam obter uma coordenação dos diferentes planos de desenvolvimento nacional para se chegar a um regime de planificação conjunta que objetive o desenvolvimento integrado da região. Nessa perspectiva, certamente o tratamento das desigualdades regionais apresenta-se teoricamente mais promissor, uma vez que a complementação dos mecanismos comerciais com o planejamento das atividades produtivas parece mais coerente com as especificidades dos países da América Latina.

Nada assegura, porém, que o planejamento integrado tenha sucesso em setores nos quais os governos nacionais, individualmente, fracassaram. Mesmo porque não existem, no Grupo Andino, políticas efetivas de redistribuição dos custos e benefícios da integração, nem mecanismos de distribuição da renda perante a realidade andina e/ou latino-americana, que apresenta uma grande concentração do desenvolvimento econômico em determinados núcleos regionais de industrialização, os quais, por sua vez, são os que realmente recebem grande parte dos benefícios da integração.

\subsection{A flexibilidade das ações na década de 1980 frente às desigualdades regionais}

Em virtude das dificuldades nas negociações comerciais da região, ficou evidente que se deveria dar vez a um processo de flexibilidade do multilateralismo radical da Alalc através de oura instituição em nível de continente, menos ambiciosa,

adaptação de um esquema ainda mais flexível de liberação comercial, na diminuição do regime rígido para o capital estrangeiro (que foi a causa da retirada do Chile em 1977) e na promoção de cooperação no desenvolvimento das fronteiras de seus países. Em 1989, na Declaração de Galápagos, os países andinos subscreveram um Compromisso Andino de Paz, Seguridade e Cooperação, no qual se fixou como meta a formação de uma união aduaneira entre Venezuela e Colômbia em 1995, o que, quatro anos depois, deveria funcionar plenamente com a Bolívia, Peru e Equador. E, finalmente, em 1990, o Grupo Andino anunciou na Ata de $\mathrm{La}$ Paz um novo prazo para a formação de uma Área de Livre Comércio e adaptação de uma tarifa extema comum em 1995. A partir dessas modificações, estabeleceu-se uma coordenação de calendários do Grupo Andino e do Mercosul (Hist \& Streb, 1993, p. 19-21). Simultaneamente, desde 1985, os membros do Grupo Andino, individualmente, vêm 
mais coerente com as desigualdades de seus países e que promovesse acordos bilaterais capazes de estimular as relações comerciais. Foi então criada, pelo Tratado de Montevidéu, de 12 de agosto de 1980, a Associação Latino-Americana de Integração (Aladi).

A nova instituição não abandona o objetivo de criar um mercado comum latino-americano, mas enfatiza que este deverá ser alcançado a longo prazo e ao qual se chegará de forma gradual. As principais modificações da Aladi em relação à Alalc, além da flexibilidade caracterizada pela capacidade de permitir a criação de acordos bilaterais, foram da os tratamentos diferenciados entre os paises, estabelecidos através do uso de mecanismos de compensação comercial de alcance regional e bilateral, e a multiplicidade, que permite a possibilidade de haver distintas formas de união econômica sub-regional entre os países-membros, em harmonia com os objetivos da integração latino-americana (Conesa, 1980).

O tratamento diferenciado entre os membros da associação se dá sobre a base de três categorias de países que se agrupam, levando em consideração seus níveis de desenvolvimento econômico: 1) os menos desenvolvidos, em que se incluem Bolívia, Equador e Paraguai; 2) os mais desenvolvidos, que agrupam Argentina, Brasil e México e 3) os de desenvolvimento intermediário, formado pela Colômbia, Chile, Peru, Uruguai e Venezuela. Contudo, chama a atenção a inexistência de uma autoridade supranacional atuante para a coordenação de políticas macroeconômicas, o que as disparidades econômicas de seus membros exige. Na verdade, a Aladi limita-se, passivamente, à criação de mecanismos de integração abrangentes que promovem acordos bilaterais, como se estivesse reconhecendo suas limitações e esperando a iniciativa dos países para uma integração mais profunda, através de acordos sub-regionais.

$\mathrm{O}$ principal instrumento de estímulo à integração por parte da Aladi é o mecanismo de Preferência Tarifária Regional ${ }^{26}$, que, partindo de um nível básico de 5\%

implementando programas de abertura econômica e ajuste estrutural, seguidos por processos de privatização e liberação para o investimento estrangeiro.

${ }^{26}$ A preferência tarifária regional aplica-se a todo o universo de produtos, menos a uma lista de exceções estabelecida por cada país de acordo com limites definidos segundo a categoria dos países. Outros mecanismos complementares são: os Acordos de Alcance Parcial, que implicam negociações entre dois países em matéria de comércio, complementação econômica ou matéria agropecuária,tendo sido 
em 1984, foi se incrementando até $10 \%$ em 1987, atingindo, finalmente, $20 \%$ em 1990. Essas preferências, no fundo, contemplam os problemas das desigualdades econômicas dos países a que o Grupo Andino chamara a atenção. Assim, os menos desenvolvidos recebem $40 \%$; os de desenvolvimento intermediário, $28 \%$ e os mais desenvolvidos, $20 \%$. Paraguai e Bolívia, por sua condição mediterrânea, têm uma margem adicional de $8 \%$.

Apesar das inúmeras possibilidades de integração apresentadas pela Aladi, as exportações de seus países evoluíram no sentido de expandir sua parcela exportadora para fora da região: 84\% em 1980 e 90,7\% em 1984 (Síntese Aladi, 1985). Observa-se também que, entre 1979 e 1982, as exportações intra-regionais caíram a uma taxa média anual de 8,2\%; as extra-regionais, por sua vez, caíram a uma taxa média anual menor de 3,2\% (Bid, 1984). Esses dados indicam a ocorrência de uma nova fase de desaceleração do comércio intra-regional, originada, talvez, da necessidade de se obter divisas para o pagamento do serviço da dívida externa. Entretanto, esse fato não necessariamente indica um processo de desintegração econômica na região, como alguns equivocadamente argumentam. Mesmo porque a retomada da integração econômica na década de 1980 obedeceu, fundamentalmente, a fatores político-econômicos ocorridos em nível regional e mundial, que apresentaram a integração regional como uma estrátegia alternativa e necessária para que os países pudessem enfrentar melhor a conjuntura internacional adversa.

Tais fatos são: a) a reabilitação das normas de convivência democrática em vários países da região, que resgataram as concretas oportunidades de complementação econômica oferecidas pela integração regional (Adams, 1990, p. 201); b) o segundo choque do petróleo, que, inicialmente, desestimulou a integração pela

negociados 130 deles; o Programa de Recuperação e Expansão do Comércio, que entrou em vigência em 1989 e tende a substituir importações de terceiros países através da negociação de uma lista de produtos que compreende $30 \%$ do que é comprado fora da região (até a atualidade, não existem resultados concretos de uso desse instrumento) e a Lista de Abertura de Mercado, que é parte do sistema de apoio aos países de menor desenvolvimento, compreendendo listas de produtos que são beneficiados com a eliminação total de tarifas, sem reciprocidade (este instrumento também não tem sido muito utilizado); por último, os Acordos Comerciais e Acordos de Complementação Econômica, que são também mecanismos bilaterais que não têm sido usados com freqüência, salvo por parte dos paises do Cone Sul (Berretta, 1993, p. 38-39). 
pressão exercida sobre a balança de pagamentos, mas que, depois, despertou renovados interesses dos países da Aladi pelo mercado intra-regional, seja por suas limitações de competitividade no mercado internacional ou por perceberam no intercâmbio regional uma forma de superar a crise econômica (Montoya, 1991, p. 165) e c) a nova tendência da economia internacional, que apresenta a integração econômica como uma condição necessária para a adoção de tecnologia, captação de investimentos estrangeiros e proteção seletiva dos mercados nacionais, como uma forma plausível de convivência com o processo de globalização financeira.

\subsection{A década de 1990: renovado vigor, a abertura e o liberalismo econômico}

A Aladi representa.a associação de comércio regional mais importante da América Latina. No entanto, seu protagonismo tem sido limitado às negociações bilaterais de comércio nas iniciativas de aprimoramento do Grupo Andino, à integração sub-regional do Mercosul e às discussões da formação da Área de Livre Comércio das Américas (Alca). Paradoxalmente, foi a mesma Aladi que estimulou o bilateralismo com sua correspondente realização de entendimentos comerciais seletivos entre alguns países-membros.

No contexto do renovado vigor que apresenta a integração econômica latino-americana nos tempos atuais, segundo Hisrt \& Streb (1993), destacam-se as seguintes características: a) todos os acordos preferenciais de comércio da região foram acompanhados pela implementação de políticas unilaterais de liberação comercial, acentuados através de reduções substanciais de tarifas e eliminação de barreiras não tarifárias; b) os interesses pelos acordos comerciais regionais foram também reforçados pelas melhores condições econômicas dos países da região ${ }^{27}$ e c) a influência crescente de critérios mais claros na formulação da política exterior tem convertido a cooperação e a integração regional nos elementos mais ativos para uma maior interdependência intra-

${ }^{27}$ O PIB da América Latina, em 1991, incrementou-se em 3\% depois de três anos de estancamento. Excluindo-se os países que sofreram níveis de inflação elevados e severos ajustes econômicos (Brasil, Peru, República Dominicana), a taxa de expansão do PIB passou para $4,5 \%$. Os níveis de inflação, que eram, em média, para 1990, de $1.200 \%$ a.a., passaram para $200 \%$ a.a. em 1991. 
regional. Isso porque as negociações comerciais não têm sido conduzidas somente por instituições governamentais, mas incluem também setores empresariais importantes, que facilitaram as reduções tarifárias.

Essas características expressam, claramente, o abandono do modelo de crescimento baseado na substituição de importações e a opção por um projeto de abertura liberal do mercado, que compatibiliza acordos regionais de comércio com certo grau de proteção. A razão disso está em se acreditar que uma maior interdependência inter-regional permite obter melhores condições de inserção no processo de globalização da economia internacional e que, através dos excedentes do comércio inter-regional, na ausência de capital estrangeiro, pode-se financiar e promover o desenvolvimento econômico regional. Até porque, nos níveis atuais de globalização financeira, o investimento direto internacional é alocado em países ou regiões que apresentam melhores atributos construídos, como, por exemplo, mão-de-obra qualificada, infra-estrutura, comunicação, estabilidade macroeconômica, etc.

Como resultado, por exemplo, o Mercosul apresenta um impacto econômico crescente e revela uma dinâmica expansiva no comércio inter-regional. As exportações de cada país para os outros, somadas, passaram de US $\$ 4.127,1$ milhões em 1990 para US\$10.027,8 milhões em 1993 e para US\$15.430,1 milhões em 1995 (Secex, 1997). Por sua vez, na década de 1990, os resultados do comércio inter-regional do Grupo Andino não são tão expressivos como os da época em que foi criado, em 1969. Por conta disso, seus membros, a partir de 1995, subscreveram o compromisso de fixar uma tarifa externa comum para a consolidação de uma União Aduaneira.

\subsection{Os novos desafios e a necessidade de um instumental sistêmico de análise que se colocam para a integração na região}

Da experiência da América Latina com a implementação de um processo de integração econômica, esperam-se três efeitos básicos: o primeiro é a ampliação da demanda inter-regional, resultante do aumento da renda dos consumidores; o segundo é $\mathrm{o}$ incremento de fluxos de abastecimento de produtos competitivos e complementares $\mathrm{e}$ 
o terceiro efeito é a redução dos preços dos produtos, fruto da eliminação das tarifas e do aumento da concorrência entre fornecedores (Montoya, 1993, p.145-150). Em conseqüência, com a simultaneidade de todos esses efeitos, espera-se uma realocação de recursos financeiros e fatores de produção que permitam o aproveitamento das vantagens comparativas dos países e as economias de escala que o novo mercado ampliado permite.

Seria ingênuo, contudo, acreditar, dadas as disparidades entre os países, que, para consolidar a integração, seja suficiente a utilização de mecanismos comerciais, deixando-se de lado as desigualdades econômicas regionais. No entanto, desde a Alalc até o Mercosul, observa-se que os mecanismos de integração efetivamente implementados têm uma orientação estritamente comercial, ou seja, as preocupações objetivam mais amenizar o sentido do comércio do que solucionar disparidades regionais.

Não surpreende, por isso, que as experiências integracionistas, frente aos objetivos propostos e às expectativas de desenvolvimento que geram, sejam frustrantes já que, inicialmente, apresentam uma expansão comercial espetacular, mas, a médio prazo, sofrem uma desaceleração rápida em virtude da imposição de barreiras não tarifárias (não-cumprimento dos acordos de integração) pelos países menos desenvolvidos. Nesse sentido, dadas as brutais desigualdades econômicas entre os países e perante a necessidade de se manter um balanço comercial equilibrado, as barreiras não tarifárias se justificam por constituírem um mecanismo eficiente para compensar as limitações dos mercados nacionais. Portanto, fica evidente que não existe, nos esquemas de integração, uma autoridade supranacional que coordene políticas macroeconômicas e implemente políticas de redistribuição dos custos e beneficios através de mecanismos de redistribuição de renda ${ }^{28}$.

Com a ausência desse tipo de mecanismo na região perante uma realidade concentradora do desenvolvimento econômico, certamente, os que mais se beneficiam

\footnotetext{
${ }^{28}$ Segundo Lizano (1973, P. 16-21), as medidas corretivas da má distribuição dos custos e benefícios, bem como da redistribuição da renda, podem ser classificadas em sete grupos: medidas comerciais, medidas monetárias e de pagamentos, medidas na esfera dos movimentos das faturas, medidas fiscais, medidas
} 
são alguns núcleos de consumo e pólos regionais industriais. Assim, de nada adiantam instrumentos que levem à unificação dos mercados, se não existem outros que redistribuam os benefícios dessa união. $\mathrm{O}$ que fazer frente a essa problemática?

A resposta, apesar de parecer extremamente difícil para sua implementação, é direta: deve-se criar uma autoridade supranacional autônoma que possa gerenciar, entre outras, políticas de redistribuição dos custos e benefícios da integração, e captar recursos financeiros comunitários. Tal autonomia significa deixá-la fora do "controle dos países", pois a experiência integracionista mundial tem demonstrado que esse instrumento acaba sendo impraticável ou utilizado com fins individuais, já que exige uma renúncia do Estado a uma receita que, em princípio, seria nacional. Existindo uma autoridade supranacional, essas receitas podem se constituir num orçamento comunitário destinado a financiar o desenvolvimento da região integrada. Para que isso funcione de forma harmônica entre os países, deve ficar bem definido quem tem que pagar e quem tem que receber. Deve-se pensar em termos de regiões mais ricas apoiando as mais pobres, como o faz o Mercado Comum Europeu (MCE), até porque, nesta instituição, acredita-se que o desenvolvimento cada vez "mais homogêneo", setorial e espacialmente, expande a interdependência intersetorial (comércio entre setores) e intra-industrial (fusão ou divisão de atividades entre as empresas), gerando maiores benefícios econômico-sociais para todos os sócios.

É evidente que, entre os países latino-americanos, não há uma distinção tão clara entre ricos e pobres e, em princípio, por exemplo, resultaria extremamente difícil que os mais desenvolvidos (no caso do Mercosul, Brasil e Argentina) transferissem renda para os menos desenvolvidos. Isso porque, entre outras razões, não só se está falando de países ricos e pobres, mas, também, de países que apresentam sérios desequilíbrios internos que se traduzem num desenvolvimento econômico concentrado e desorganizado.

Desde que se consiga, entretanto, aumentar a interdependência intersetorial e intra-industrial de suas economias de forma harmônica, essas indefinições

na esfera dos serviços comuns, medidas financeiras e medidas para a designação direta de atividades econômicas. Todas essas objetivam compensar ou corrigir os desequilibrios regionais entre os países. 
poderão ser superadas. Basta ver que, num sistema econômico integrado, por exemplo, as ligações interindustriais para trás e para frente, os multiplicadores setoriais, os efeitos de transbordamento e a renda gerada pelo setor serviços, entre outros, se expandem ao ponto de promoverem o crescimento econômico conjunto dos países. Portanto, financiar o desenvolvimento da região integrada, seja com os excedentes do comércio intraregional seja com a arrecadação do movimento de mercadorias, etc., significa construir melhores atributos nos mercados (capital humano, infra-estrutura, comunicações, estabilidade macroeconômica), que possibilitarão o fortalecimento econômico da região.

A questão, então, é: como convencer os países com desenvolvimento altamente heterogêneo de que as transferências de renda, no sistema econômico integrado, lhes trarão beneficios concretos num futuro próximo?

Com base na perspectiva empírica, parece razoável pensar que isso poderá ser alcançado através da visualização pelos países das reais vantagens de financiar políticas de integração econômica regional. Certamente, para isso, é preciso desenvolver um instrumental analítico integrado em matéria de medição dos efeitos de encadeamento entre os países. Esse instrumental, propõe-se, deve ser do tipo insumoproduto, pois, em sua concepção, ao considerar que cada produto pode ser interpretável como um insumo, à medida que seja aproveitado por outro sistema em cadeia, permite, intersetorialmente, uma análise econômica sistêmica de equilíbrio geral.

Com esse tipo de instrumental, que considera a realidade econômicocontábil dos países, a coordenação de políticas macroeconômicas e a implementação de políticas redistributivas por parte de uma autoridade supranacional deverão ser facilitadas. Obviamente, não se espera que exista consenso sobre o tipo de instrumental analítico que se deva utilizar, entretanto deve ficar claro que, para definir as diretrizes de um processo de integração, é necessária uma autoridade supranacional autônoma ciente das gritantes desigualdades regionais, haja vista que ficou notório, desde a Alalc até o Mercosul, que a distribuição dos "custos e benefícios" tem sido o calcanhar de Aquiles dos processos de integração econômica na região. 



\section{TEORIA E QUADRO GERAL DOS MODELOS INSUMO-PRODUTO}

No capítulo anterior, foi salientado, entre outros, a necessidade de desenvolver um instrumental analítico intersetorial que considere as desigualdades de desenvolvimento econômico dos países-membros do Mercosul. Nesse sentido, o presente tem por objetivo, sob a ótica estática, estabelecer um arcabouço teórico básico para a construção e implementação empírica de um modelo de insumo-produto na região. Para isso: a) faz uma breve apresentação da teoria básica dos modelos de equilíbrio geral de insumo-produto e de seu quadro simplificado; b) realiza uma classificação dos modelos de insumo-produto que incorporam varias regiões e países, bem como discute seus alcances e limitações para mensurar as relações inter-regionais que se estabelecem com o comércio internacional.

\subsection{A teoria básica dos modelos de insumo-produto}

A teoria de insumo-produto é o resultado dos estudos publicados no final da década de 1930 pelo economista Wassily Leontief, que desenvolveu, pela primeira vez, a análise dos grandes agregados macroeconômicos em termos de insumo-produto. Para isso, utilizou o sistema de equilíbrio geral de Walras, dando-lhe, porém, um conteúdo e aplicabilidade empírica através da simplificação de equações que a tornaram mais inteligível (Langoni in Leontief, 1983, vii apr.). A partir disso, a análise de insumoproduto passou a se constituir numa extensão prática da teoria clássica de interdependência geral, que vê a economia inteira de uma região, de um país ou, inclusive, do mundo como um só sistema, propondo que se interpretem todas as suas 
funções em termos das propriedades específicas mensuráveis de sua estrutura (Leontief, 1983, p.5).

Para desenvolver o modelo teórico de insumo-produto, Leontief estabeleceu, à maneira de Quesnay, um quadro econômico em que a economia é descrita em termos de circulação, isto é, como um sistema integrado de fluxos e transferências de insumos e produtos de um setor a outro. Cada setor absorve insumos de outros setores, além de produzir bens e serviços que, por sua vez, serão utilizados por outros setores para serem processados ou para um consumo final (Miller e Blair, 1985, p.2). Assim, todas as vendas são igualmente compras; todas as saídas são, a um tempo, também entradas; todos os produtos são genuinamente insumos à medida que sejam aproveitáveis por outro sistema em cadeia.

Com esse raciocínio, a construção do quadro insumo-produto para um conjunto de setores, para as diversas regiões de um país e/ou conjunto de países representa um elemento de análise econômica materialmente consistente e empiricamente instrumentável. Com seu uso, é possível detectar as conseqüências que uma mudança num setor da economia acarreta para outro setor e para o conjunto, o que permite, em essência, o planejamento econômico tanto no enfoque macroeconômico como no microeconômico.

Nesse contexto, Leontief (1951), ao elaborar a teoria de insumo-produto, assume que existe, num dado nível de preços, equilíbrio simultâneo entre os mercados consumidor e produtor, isto é, equilíbrio geral na economia. Tudo isso dentro dos pressupostos da microeconomia clássica, na qual não existe ilusão monetária dos agentes econômicos.

Considere-se a seguinte identidade, na qual a economia é dividida em $n$ setores:

$$
\sum_{i=1}^{n} x_{i j}+C_{i}+G_{i}+I_{i}+E_{i}-M_{i}=X_{i} \quad i=1,2, \ldots, n
$$

onde: 
$x_{i j}$ é a produção do setor $i$ que é utilizada como insumo intermediário pelo setor $j$;

$C_{i}$ é a produção do setor $i$ que é consumida pelas famílias;

$G_{i}$ é a produção do setor $i$ que é consumida pelo governo;

$I_{i}$ é a produção do setor $i$ que é destinada ao investimento;

$E_{i}$ é a produção do setor $i$ que é exportada;

$M_{i}$ é o volume de importações do setor $i$;

$X_{i}$ é a produção doméstica total do setor $i$ (produção total do setor $i$

utilizada como insumo intermediário e como demanda final).

Assumindo que os fluxos intermediários por unidade do produto final são fixòs, pode-se derivar o sistema aberto de Leontief, ou seja,

$$
\sum_{j=1}^{n} a_{i j} X_{j}+Y_{i}-M_{i}=X_{i}
$$

onde:

$Y_{i}$ é a demanda final da produção do setor $i$, isto é, $C_{i}+G_{i}+I_{i}+E_{i}$;

$a_{i j}$ é a produção necessária do setor $i$ para a produção de uma unidade de produção total do setor $j$, sendo $a_{i j}<1$ e $\left(1-a_{i j}\right)>0$.

O conjunto de coeficientes $a_{i j}$ constitui a matriz $A$, de modo que os $a_{i j}$ descrevem, em cada coluna da matriz $A$, a estrutura tecnológica do setor correspondente. Seus valores são fixos e definem funções de produção lineares e homogêneas para os setores $j$, que podem ser representados, genericamente, pela seguinte equação (uma relação técnica entre variáveis):

$$
x_{i j}=a_{i j} X_{j} \quad(i, j=1,2, \ldots n)
$$

A equação (4.2) pode ser escrita em forma matricial como: 


$$
A X+Y-M=X
$$

onde:

$A$ é a matriz de coeficientes técnicos diretos de insumos de ordem $(n \times n)$; $Y$ e $M$ são vetores colunas de ordem $(n \times 1)$.

Assumindo que as variações da demanda final, $Y$, são determinadas exogenamente, resolvendo a equação (4.4), é possível se obter a produção total, $X$, que é necessária para satisfazer a demanda final menos importação, ou seja,

$$
X=(I-A)^{-1}(Y-M)
$$

onde $(I-A)^{-1}$ é a matriz de coeficientes técnicos de insumos diretos e indiretos, ou a matriz de Leontief, sendo que, em $B=(I-A)^{-1}$, cada elemento $b_{i j}$ da matriz inversa de Leontief deve ser interpretado como os requisitos diretos e indiretos da produção total do setor $i$, que são necessários para produzir uma unidade de demanda final do setor $j$. Estes elementos têm as seguintes características:

a) $b_{i j} \geq a_{i j}$, ou seja, cada elemento da matriz inversa de Leontief é maior ou igual ao respectivo elemento na matriz tecnológica, uma vez que o elemento $b_{i j}$ indica os efeitos diretos e indiretos sobre a produção do setor $i$ para atender a uma unidade monetária de demanda final no setor $j$, enquanto o elemento $a_{i j}$ indica apenas os efeitos diretos; a igualdade entre os dois coeficientes ocorre no caso particular em que os efeitos indiretos são nulos;

b) $b_{i j} \geq 0$, vale dizer, como os coeficientes técnicos de produção são fixos, não há possibilidade de substituição de insumos, de tal forma que uma expansão na demanda final do setor $j$ irá provocar um efeito positivo ou nulo sobre a produção do setor $i$, nunca um efeito negativo; o efeito nulo surgirá se não houver interdependência direta entre os setores $i$ e $j$;

c) $b_{i j} \geq 1$, se $i=j$, isto é, os elementos da diagonal principal da matriz inversa de Leontief serão sempre iguais a 1 ou maiores do que 1 , uma vez que o 
acréscimo de uma unidade monetária na demanda final de um setor deverá provocar uma expansão na produção deste setor de pelo menos uma unidade monetária.

Cabe salientar que as variáveis utilizadas nesta teoria são originalmente expressas em termos de relações físicas entre insumos e produto, porém, em termos empíricos, para viabilizar sua utilização, a construção do quadro insumo-produto que serve para estimar as matrizes $A$ e $B$ está baseada em fluxos monetários.

$\mathrm{O}$ fato de as matrizes $A$ e $B$ serem estimadas a partir de fluxos monetários pode afetar os valores dos coeficientes técnicos dadas as mudanças dos preços relativos (Nações Unidas, 1966). Para resolver este problema, o que se faz usualmente, em termos analíticos, é assumir que os preços são constantes (Miller e Blair, 1985).

Apesar desses problemas, a análise de insumo-produto se constitui numa ferramenta poderosa, talvez a. melhor disponível, quando se faz necessário o desenvolvimento de um estudo intersetorial em nível regional, em nível inter-regional (Guilhoto, 1995, p. 6) e em nível internacional. Essa, talvez, tenha sido a razão mais importante do porquê de, no início da década de 1960, mais de quarenta nações terem adotado modelos baseados na teoria de insumo-produto e, na atualidade, serem poucos os países que não a usam para o planejamento de suas economias.

\subsubsection{O Quadro do Insumo-Produto}

A descrição que, por si, representa o quadro insumo-produto de um sistema econômico em um determinado período de tempo permite evidenciar a estrutura produtiva de um sistema econômico, a forma de sua organização e a consistência contábil das estatísticas. No quadro insumo-produto, a estrutura do sistema econômico aparece, em geral, dividida em oito seções (Tabela 4.1).

As seções, respectivamente, descrevem as seguintes atividades interdependentes: 1) os produtos intermediários, compostos por bens e serviços produzidos nos setores industriais e consumidos como produtos intermediários pelo próprio setor ou por outros setores industriais; 2) os produtos dos setores industriais que se destinam a consumo final, formação de capital, consumo do governo, exportações e 
variação de estoques; 3) o valor total da produção em cada setor industrial; 4) os custos primários em cada setor industrial, compostos pela remuneração aos serviços dos fatores de produção, depreciação do capital fixo, etc.; 5) os bens e serviços finais não produzidos nos setores industriais: valor adicionado pelo setor público, importação de bens e serviços finais, etc.; 6) o valor de cada categoria de custo primário; 7) o consumo total de cada setor industrial; 8) o valor de cada categoria de demanda final.

Tabela 4.1. Estrutura básica geral do quadro insumo-produto.

\begin{tabular}{c|c|c}
\hline $\begin{array}{c}(1) \\
\text { produção intermediária }\end{array}$ & $\begin{array}{c}(2) \\
\text { produção final }\end{array}$ & $\begin{array}{c}(3) \\
\text { produção total }\end{array}$ \\
\hline (4) & $(5)$ & $(6)$ \\
insumo primário & insumo primário/produto final & $(8)$ \\
\hline insumos totais & custo primário total \\
\hline
\end{tabular}

Fonte: Haddad (1976, p.99).

As relações contábeis existentes entre essas seções, na prática, podem ser visualizadas por meio do quadro de insumo-produto simplificado da Tabela 4.2.

Tabela 4.2. Quadro de insumo-produto simplificado segundo o modelo de Leontief.

\begin{tabular}{|c|c|c|c|c|c|c|c|c|c|c|c|}
\hline \multirow{2}{*}{\multicolumn{2}{|c|}{ Setores }} & \multicolumn{9}{|c|}{ Compras () } & \multirow{4}{*}{$\begin{array}{c}\begin{array}{l}\text { Total } \\
\text { produto } \\
\left(X_{i}\right)\end{array} \\
X_{1}\end{array}$} \\
\hline & & \multicolumn{4}{|c|}{ Demanda intermediária } & \multicolumn{5}{|c|}{ Demanda final } & \\
\hline & & Setor & Setor & Setor & $\bar{\Sigma}$ & $\mathrm{C}$ & $\mathbf{G}$ & 1 & $E$ & $\Sigma$ & \\
\hline \multirow{4}{*}{$\begin{array}{c}\mathrm{V} \\
\mathrm{e} \\
\mathrm{n} \\
\mathrm{d} \\
\mathrm{a} \\
\mathrm{s} \\
(\mathrm{I})\end{array}$} & $\begin{array}{c}\text { Setor } \\
1\end{array}$ & $x_{11}$ & $x_{12}$ & $x_{13}$ & $\overline{W_{1}}$ & $\overline{C_{1}}$ & $\overline{G_{1}}$ & $I_{1}$ & $\overline{E_{1}}$ & $\overline{Y_{1}}$ & \\
\hline & $\begin{array}{c}\text { Setor } \\
2\end{array}$ & $x_{21}$ & $x_{22}$ & $x_{23}$ & $\overline{W_{2}}$ & $\overline{C_{2}}$ & $\overline{G_{2}}$ & $I_{2}$ & $E_{2}$ & $Y_{2}$ & $X_{2}$ \\
\hline & $\begin{array}{c}\text { Setor } \\
3\end{array}$ & $x_{31}$ & $x_{32}$ & $x_{33}$ & $W_{3}$ & $\overline{C_{3}}$ & $\overline{G_{3}}$ & $I_{3}$ & $\overline{E_{3}}$ & $Y_{3}$ & $X_{3}$ \\
\hline & $\Sigma$ & $U_{1}$ & $\overline{U_{2}}$ & $\overline{U_{3}}$ & ${ }_{j}=W_{i}$ & $\overline{C_{j}}$ & $\overline{G_{j}}$ & $\bar{I} I_{j}$ & $\overline{E_{j}}$ & $Y_{j}$ & $\sum_{j} X_{i}$ \\
\hline \multicolumn{2}{|c|}{$M$} & $\bar{M}_{1}$ & $M_{2}$ & $\overline{M_{3}}$ & $M_{j}$ & & & & & & \\
\hline \multicolumn{2}{|c|}{$T M$} & $T M_{1}$ & $T M_{2}$ & $T M_{3}$ & $T M_{4}$ & & & & & & \\
\hline \multicolumn{2}{|c|}{$\bar{V}$} & 1 & 2 & 3 & $j$ & & & & & & \\
\hline \multicolumn{2}{|l|}{$\begin{array}{l}\text { Total } \\
\text { insumo }\end{array}$} & $X_{1}$ & $X_{2}$ & $X_{3}$ & $\sum_{i} X_{j}$ & & & & & & \\
\hline
\end{tabular}


Por exemplo, na Tabela 4.2, os setores produtivos do sistema econômico estão agregados em três grandes grupos: agricultura, indústria e serviços. Os valores do sistema podem ser expressos a preços básicos (compreende as despesas com matériaprima e mão-de-obra), a preços de mercado ou de consumidor (preço básico + margens de comercialização + impostos sobre a comercialização) e a preços de produtor (preço básico + impostos).

As variáveis do quadro insumo-produto simplificado são definidas da seguinte maneira:

$$
W_{j}=\text { produção do setor } i \text { utilizada como insumo intermediário, }
$$
$W_{i}=\sum_{j} x_{i j}$

$Y_{i}=$ demanda final da produção do setor $i$ (está composta por $\mathrm{C}_{i}+\mathrm{G}_{i}+\mathrm{I}_{i}$ $\left.+\mathrm{E}_{i}\right)$

$X_{i}=$ oferta total do setor $i$ ou valor bruto da produção $i$, ou seja, $X_{i}=\sum_{j}\left(W_{i}+Y_{i}\right)$

$U_{j}=$ despesas com insumos intermediários $i$ pelo setor $j$;

$M_{j}=$ volume de importações do setor $j$;

$T M_{J}=$ tributos pagos pelo setor $j$ devido a suas importações;

$V_{j}=$ valor adicionado gerado pelo setor $j$ (está composto pelo somatório das remuneração do trabalho no setor $j\left(R L_{j}\right)$, da remuneração do capital no setor $j\left(R k_{j j}\right)$ e dos tributos pagos pelo setor $j\left(T r_{j}\right)$;

$X_{j}=$ custo de produção total do setor $j$;

$n=$ número de setores produtivos.

Todas as outras variáveis já foram definidas anteriormente.

$\mathrm{O}$ quadro de insumo-produto simplificado mostra na linha horizontal, por exemplo, que o setor agricultura produz $X_{1}$ de unidades monetárias, as quais foram consumidas na fase de demanda intermediária por ele mesmo, pelos setores indústria e serviços e o restante pelos componentes da demanda final, $Y_{1}$; na linha vertical, por sua 
vez, mostra as despesas de matérias-primas, $U_{1}$, de origem agrícola, industrial e serviços; outra com os insumos importados e, finalmente, uma com os componentes do valor adicionado bruto, $V_{1}$ do setor.

Generalizando essas relações contábeis entre as variáveis, tem-se

$$
X_{i}=\sum_{j} x_{i j}+Y_{i}=W_{i}+Y_{i} \quad(i=1,2, \ldots, n)
$$

isto é, para cada mercadoria $i$, o total da oferta é igual ao total da demanda, a qual se compõe da demanda intermediária e da demanda final. Da mesma forma, tem-se

$$
X_{j}=\sum_{i} x_{i j}+V_{i}=U_{j}+V_{j} \quad(j=1,2, \ldots, n)
$$

ou seja, a produção total em cada setor é igual ao valor de insumos comprados de outros setores mais o valor adicionado nesse setor.

Para mostrar as relações existentes entre os valores que compõem o quadro de insumo-produto e os agregados dos contas nacionais de uma região em um mesmo período, somamos os elementos de todas as linhas:

$$
\sum_{i} X_{i}=\sum_{j} \sum_{i} X_{i j}+\sum_{i} Y_{i} \quad(i, j=1,2, \ldots, n)
$$

Somando igualmente os elementos de todas as colunas, temos

$$
\sum_{j} X_{j}=\sum_{j} \sum_{i} X_{i j}+\sum_{j} V_{j}
$$

Como se trata de um sistema de equilíbrio geral, então, 


$$
\sum_{i} X_{i}=\sum_{j} X_{j}
$$

Portanto, o quadro insumo-produto, em termos contábeis, será consistente.

\subsection{Os modelos inter-regionais e internacionais de insumo-produto}

$\mathrm{Na}$ literatura, os modelos que utilizam as relações básicas de insumoproduto são classificados como estáticos ou dinâmicos. Tais modelos, por sua vez, segundo Guilhoto (1995, p.6-9), são denominados de otimização ou não, quando se utilizam de qualquer forma de programação linear ou não linear para obter os resultados do sistema. Os modelos estáticos, geralmente, baseiam-se nos coeficientes da matriz de Leontief, sendo usados para prever o uso de fatores das mais diversas políticas econômicas. Já os modelos dinâmicos incorporam no modelo estático de insumoproduto uma teoria de investimentos que coloca o sistema em movimento, na qual a demanda atual por bens de investimento depende das expectativas futuras com relação ao aumento em nível de produção. Discussões sobre esses modelos podem ser encontradas em Haddad (1976), Miller e Blair (1985).

A tipificação de modelos estáticos ou dinâmicos, de otimização ou não, torna-se, entretanto, extremamente genérica quando se deseja visualizar a estrutura de construção das matrizes inter-regionais. Com vistas a superar este problema, passa-se a classificar de forma menos genérica os diferentes modelos de insumo-produto, levandose em consideração a natureza das informações estatísticas utilizadas e os métodos de estimação das matrizes. Espera-se, através deste enfoque, que fiquem evidentes as limitações e alcances dos diferentes modelos inter-regionais e internacionais para a construção da matrizes insumo-produto do Mercosul. 


\subsubsection{Quadro geral e classificação}

Não há dúvida de que, desde que Isard (1951) e Leontief (1951) perceberam extensões inter-regionais e internacionais ao modelo insumo-produto possivelmente por influência do trabalho de Metzler (1950) sobre a teoria da determinação da renda num sistema de regiões -, ficou evidente que as limitações de dados dos fluxos inter-regionais e internacionais de mercadorias ou o custo de sua obtenção seriam sérios obstáculos a serem enfrentados. Não surpreende, portanto, na literatura, o interesse quase que espontâneo em desenvolver métodos que se utilizam de informações não provenientes de um processo censitário para estimar e facilitar o uso de matrizes insumo-produto inter-regionais e seus multiplicadores setoriais que evitem incorrer em custos financeiros elevados. Esses métodos alternativos de estimação são denominados em geral como métodos sem informação censitória ${ }^{29}$

Para Roundt (1983), os termos sem informação censitária e com informação censitária sugerem a existência de dois grupos bem definidos e mutuamente excludentes; na prática, porém, o autor afirma que todas as matrizes insumo-produto são matrizes híbridas construídas por meio de técnicas com informação semi censitária, que empregam dados primários e secundários em uma extensão maior ou menor. Dessa maneira, pode haver poucas matrizes insumo-produto inter-regionais, ou nenhuma, que não tenham sido confiadas a um certo uso de indicadores ou a algumas técnicas que tornem os dados mais sensíveis.

$\mathrm{Na}$ literatura, contudo, quando as observações diretas não são disponíveis, ou quando os dados do censo são inconsistentes, qualquer técnica que gere coeficientes dos fluxos comerciais ou ajuste estimadores consistentes baseados diretamente em dados censitários é denominada, indistintamente, como método sem informação censitária ou com informação semi censitária, ou seja, não existe um padrão predefinido aceitável para diferenciar, com clareza, os dois métodos.

${ }^{29}$ Em geral, a técnica de estimação desses métodos consiste em calcular a proporção de suprimentos de mercadorias localnente produzidas e importadas, a partir de uma matriz de coeficientes técnicos de produção ou, às vezes, de uma matriz de insumo-produto para uma nação como um todo (Roundt, 1978). 
Nessas circunstâncias, como forma mais adequada de distinguir os métodos empregados na construção de matrizes, que permita uma classificação precisa dos diversos modelos inter-regionais e sua extensão para os modelos internacionais, passamos a classificar os métodos, na Figura 4.1, de acordo com a natureza dos dados utilizados e suas respectivas técnicas de estimar coeficientes interindustriais como:

a) métodos com informação censitária, quando as informações estatísticas utilizadas são diretas;

b) métodos com informação censitária limitada, quando as informações utilizadas são estimativas das informações diretas requeridas. Desse modo, os métodos denominados na literatura como sem informação censitária e com informação semi censitória estarão agrupados dentro da segunda categoria.

Note-se, nessa classificação, que os métodos com informação censitária limitada podem ser divididos, de acordo com as técnicas de estimação utilizadas na construção de matrizes insumo-produto, em três grupos: métodos do quociente, métodos do balanço de mercadorias e métodos iterativos. Na prática, porém, quando se implementa uma matriz insumo-produto, com freqüência, esses métodos não são excludentes entre si, já que podem ser utilizados de forma combinada.

Sob o particular, Roundt (1972), ao avaliar o desempenho das técnicas de estimação desses métodos, conclui que os métodos do quociente e do balanço de mercadorias pertencem a uma mesma classe de técnica. Os métodos iterativos e de balanço de mercadorias também são formalmente similares ${ }^{30}$, de tal forma que os métodos do quociente devem ser considerados como sendo típicos da classe geral desses três métodos.

${ }^{30}$ Os métodos iterativos, também conhecidos como métodos RAS, utilizam melhor os dados e as informações que, geralmente, estão disponíveis em nível regional e, especialmente, quando são usadas para atualizar matrizes com intervalos de tempo que oscilem em torno de uma década e quando não tenham ocorrido mudanças significativas na estrutura produtiva. 


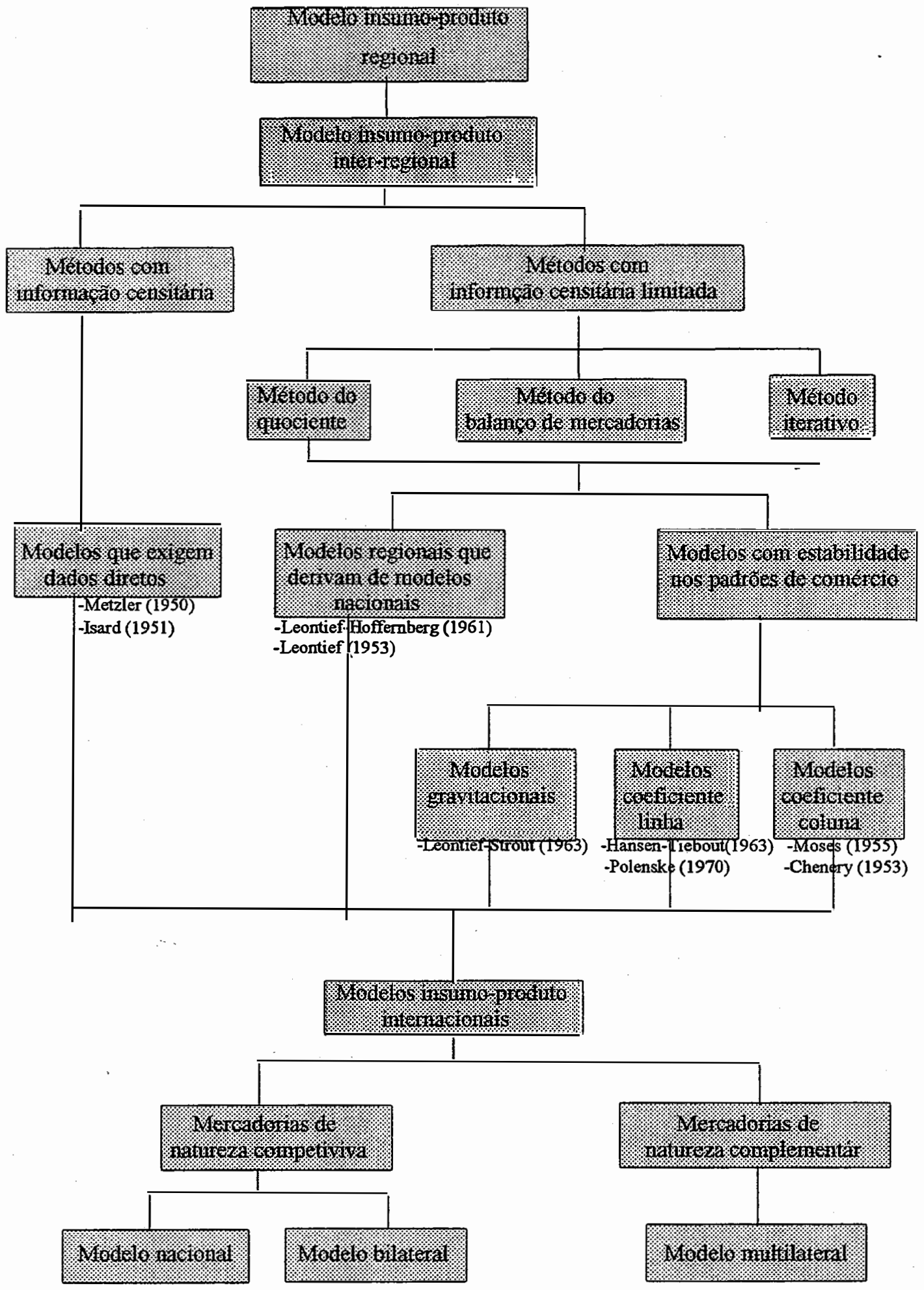

Figura 4.1 - Classificação dos modelos insumo-produto inter-regionais e sua extensão para os modelos de insumo-produto internacionais. 
O procedimento geral do método do quociente consiste em comparar a participação percentual da mercadoria de uma região em um setor particular com a participação percentual da mesma mercadoria regional e com o total da produção de bens nacionais. $\mathrm{O}$ valor do quociente indica uma orientação do produto à importação, quando for menor que 1; à exportação, quando for maior que 1, e à auto-suficiência, quando for igual a $1^{31}$.

Com base na diferenciação dos métodos com informação censitária e com informação censitária limitada e seguindo os trabalhos de Bom (1984) e Cavalcanti (1994), os modelos inter-regionais podem ser classificados, de acordo com o enfoque ou maneira de calcular os coeficientes técnicos, em três grupos diferentes (Figura 4.1):

1) modelos que exigem a utilização de dados diretos na construção de matrizes insumo-produto para cada região, além de uma matriz dos fluxos interregionais, tal como o proposto por Isard (1951);

2) modelos nos quais os totais regionais derivam do modelo de insumoproduto nacional. Estes modelos também são denominados intranacionais, tal como foi proposto por Leontief (1953) e Leontief-Hoffernberg (1961);

3) modelos que assumem uma certa estabilidade nos padrões de comércio inter-regional, representando uma simplificação do modelo de Isard.

Ainda, dentro deste último grupo, de acordo com as proporções delimitadas para comprar ou vender, os modelos podem ser classificados em três subgrupos:

a) modelos gravitacionais, propostos inicialmente por Leontief-Strout (1963), nos quais os fluxos de comércio estão associados a custos de transferência e os setores produtores e compradores não fazem referência à origem ou destino dos insumos desde que sejam idênticos;

${ }^{31}$ Duas variantes-padrão de quocientes são freqüentemente utilizadas na construção de matrizes: o quociente de locação e o quociente de "indústria cruzada". Estes quocientes são expressos em termos de produtos brutos de setores regionais ou nacionais. A variável emprego tem sido usada com freqüência; já a variável produto é preferida como uma medida do tamanho do setor, uma vez que isso evita os problemas de se assumir como constante a produtividade das regiões (Roundt, 1978) e (Miller \& Blair, 1985). 
b) modelos de coeficientes linha, apresentados por Hansen \& Tiebout (1963) e Polensk (1970), que enfocam em sua construção a distribuição da produção regional que se destina ao mercado doméstico ou à exportação para outras regiões. A característica principal deste modelo é que a proporção do produto vendida pelas diversas regiões é a mesma, independentemente do nível de demanda das regiões compradoras;

c) modelos de coeficiente coluna, nos quais o número de regiões e de setores é dado e cada região importa uma proporção fixa de suas necessidades, de um dado produto, de uma região específica; assim, cada setor segue o mesmo padrão da região como um todo. Os pioneiros na utilização destes modelos foram Chenery (1953) e Moses (1955).

Independentemente da classificação de métodos com informação censitária ou métodos com informação censitária limitada, os modelos insumo-produto internacionais são uma extensão dos modelos inter-regionais que, por sua vez, derivam do primeiro modelo insumo-produto regional de Leontief (1951). Entretanto, dois pressupostos fundamentais devem ser adicionados para distinguir os modelos internacionais: as taxas de câmbio dos países permanecem constantes e as relações interindustriais entre os países parceiros deverão ser expressas, de acordo com conceito de construção, a preços CIF ou FOB, independentemente de os fluxos serem de importações ou exportações.

Para a implementação de um modelo internacional, inicialmente, é definido um sistema econômico unitário constituído por dois ou mais países que apresentam relações comerciais, para os quais não implica, necessariamente, que exista vizinhança geográfica. A partir desse ponto, cada país do novo sistema econômico representa uma região, ficando evidente, conseqüentemente, a idéia de um modelo interregional.

Nesse contexto, as estruturas de construção de matrizes no âmbito internacional podem ser classificadas em dois grupos, de acordo com o tratamento que se dá às mercadorias importadas (Figura 4.1). O primeiro grupo assume que os bens importados e os bens domésticos são competitivos entre si e o segundo grupo, que os 
bens importados e os bens domésticos são complementares, porque diferem em suas características, isto é, eles não são substitutos e há uma necessidade, na estrutura do modelo, de diferenciar os fluxos entre os bens domésticos e os importados. Uma discussão detalhada sobre esses modelos pode ser encontrada em Furukawa (1986).

Os modelos do tipo importações competitivas desdobram-se em modelos nacionais e modelos bilaterais. Estes modelos não diferenciam as estruturas de transações entre diferentes indústrias de dois ou mais países. Dessa maneira, no caso de modelos nacionais (regional), não existe distinção entre bens domésticos e importados já que, na matriz, eles aparecem agregados. No caso de modelos bilaterais, os insumos intermediários entre dois países são desagregados entre bens importados e domésticos, porém não se conhecem as relações interindustriais entre os dois países. Portanto, se o objetivo é tornar clara a estrutura de transações entre as indústrias de dois ou mais países, esses modelos não são adequados visto que não desagregam as importações e as exportações em nível de país e indústria.

Já os modelos do tipo não competitivo, ou também denominados modelos multilaterais, apresentam os fluxos de importação desagregadas por origem e destino, de modo que as importações das indústrias de um país constituem-se nas exportações das indústrias de outro país. Assim, se, eventualmente, todos os países dispusessem de uma matriz insumo-produto, poder-se-ia construir uma matriz internacional para todo o mundo.

É óbvio que algumas variáveis novas são adicionadas à matriz internacional, como, por exemplo, setores de seguro e frete internacional, setores de importação e exportações do restante do mundo, setores de mercadorias em trânsito, setores de impostos sobre as importações, etc. Contudo, o funcionamento do modelo internacional é semelhante ao do modelo inter-regional de Isard.

\subsection{Os modelos com informação censitária: alcance e limitações}

Em seqüência, discutem-se os modelos insumo-produto inter-regionais com informação censitáría mais representativos da literatura, com o objetivo de 
estabelecer o grau de especificidade de suas relações intersetoriais, sua coerência com a teoria do equilíbrio geral e sua perspectiva empírica.

\subsubsection{O modelo de Metzler}

Os modelos inter-regionais ou multirregionais que se utilizam da teoria do insumo-produto têm sua origem no artigo clássico de Metzler (1950) sobre a teoria da determinação da renda num sistema de regiões sem comércio internacional. Nesse sentido, para avaliar os efeitos do investimento nas diversas regiões, o autor analisa os impactos dos efeitos de transbordamento inter-regional decorrentes de uma variação autônoma da demanda final em uma das regiões e suas conseqüentes implicações nas transações comerciais entre as regiões.

Com o objetivo de captar as variações de emprego e de renda real, o modelo pressupõe que todos os preços, custos e taxas de câmbio permanecem constantes no período de análise e que as importações de uma região ou país são limitadas apenas pelo seu nível de renda. O modelo é de curto prazo, não considerando, portanto, os efeitos dos investimentos líquidos sobre a capacidade produtiva da região ou as repercussões de uma variação nessa capacidade sobre a demanda para novas inversões.

Tendo em vista que as exportações de uma região constituem as importações das outras regiões do mesmo sistema, as transações inter-regionais no modelo são expressas em termos de funções de importação. Assim, dependendo do grau de agregação, é possível distinguir entre multiplicadores da região como um todo (quando as exportações são determinadas de forma autônoma e a análise das suas repercussões se restringe aos efeitos que impactam o nível de renda e de emprego da região exportadora) e multiplicadores inter-regionais (quando as exportações de uma região são função da renda em todas as demais regiões com que mantém transações externas).

O sistema econômico que representa o modelo é, entretanto, limitado na análise de problemas regionais já que não discrimina os efeitos inter-regionais por setor produtivo de cada região onde ocorrem as despesas. Trata-se, portanto, de um modelo 
inter-regional do tipo agregado, pelo qual não é possível visualizar os efeitos econômicos nos setores produtivos de cada região, ou seja, nesse nível, não se sabe quem compra ou quem vende insumos e produtos.

No Brasil, esse modelo foi utilizado por Haddad e Andrade (1974) para analisar a política fiscal e os desequilíbrios regionais que ocorreriam em razão da mudança do Imposto de Vendas e Consignações (IVC) para o Imposto de Circulação de Mercadorias (ICM). A conclusão fundamental dos autores foi de que há necessidade de que seja reexaminada a tese de que "gastando-se nas áreas desenvolvidas do país, acabase, em última instância, trazendo grandes beneficios para as áreas menos desenvolvidas", visto que o efeito de "transbordamento" parece operar no sentido inverso à tese referida.

\subsubsection{0 modelo de Isard}

O modelo de Isard (1951 ou 1960), na literatura de insumo-produto, apresenta-se como o ideal para que se possa mensurar relações inter-regionais "dentro" de um país ou em situações que envolvem diferentes países. Isard parte do princípio de que os fluxos geográficos de mercadorias podem ser atribuídos, de modo geral, a dois conjuntos básicos de fatores: primeiro, os relacionados com as desigualdades na distribuição espacial da população, renda e recursos, e segundo, os que envolvem a indivisibilidade de produção e conseqüentes economias de escala. Assim, argumenta que a elaboração de um modelo inter-regional deve reconhecer a existência dessas desigualdades geográficas, bem como a heterogeneidade das áreas dos mercados existentes. Em conseqüência, considera que uma determinada mercadoria, ou serviço, produzida numa região, em seu modelo, será considerada como diferente da mesma mercadoria, ou serviço, produzida em outra região.

Desse modo, os supostos básicos que norteiam o modelo são: a) há uma função de produção do tipo Leontief específica para cada setor de cada região; b) os coeficientes técnicos dependerão não somente da tecnologia utilizada e da estrutura de 
preços relativa, mas, também, da organização atual dos fluxos regionais de abastecimento em cada setor.

Com base nisso, as relações contábeis da matriz de Isard indicam que o número de células no quadrante das relações interindustriais será igual ao número de setores multiplicado pelo número de regiões, uma vez que o modelo especifica a distribuição da produção de cada setor em cada região, para os diversos setores de todas as regiões, ou seja, o modelo estabelece que existem relações interindustriais em nível intra-regional e inter-regional

Analogamente ao modelo básico de insumo-produto de Leontief, o modelo de Isard estabelece uma matriz inversa, ṇa qual não só a estrutura tecnológica permanecerá constante, mas também a estrutura de abastecimento inter-regional em nível de cada setor. Assim, sendo conhecida a demanda final de cada região, o modelo permite a análise de problemas que envolvem efeitos de transbordamento inter-regional; implicações inter-regionais, quando ocorre variação exógena na demanda final de uma determinada região; incremento das exportações para outros países; programas de investimentos; aumento do consumo autônomo, etc.

$\mathrm{Na}$ implementação desse modelo a partir da perspectiva empírica, exigese a coleta de um imenso e diversificado volume de informações estatísticas. Dessa forma, seu uso se restringe a alguns países, como, por exemplo, USA, Holanda e Japão, pois os recursos financeiros e humanos exigidos para a coleta de dados dessa natureza são elevados (Miller \& Blair, 1985). Porém, na evolução da teoria do insumo-produto, os modelos inter-regionais alternativos, considerando as limitações de dados, tendem a aproximar-se do modelo de Isard.

\subsection{Os modelos com informação censitária limitada: alcance e limitações}

O objetivo desta parte é estabelecer o grau de especificidade das relações intersetoriais que apresentam os modelos, sua coerência com a teoria do equilíbrio geral e sua perspectiva empírica. Nesse sentido, a seguir, discutem-se os modelos insumo- 
produto inter-regionais com informação censitária limitada mais representativos da literatura.

\subsubsection{0 modelo de Leontief-Hoffernberg}

O modelo intranacional de Leontief-Hoffernberg (1961 ou 1983) supera, em parte, o problema da falta de especificação dos efeitos inter-regionais, característica do modelo de Metzler, tratando de diminuir a necessidade de dados que o modelo de Isard requer. Para isso, combina a estrutura conceitual da análise de insumo-produto com a observação empírica de que algumas mercadorias são produzidas em lugares próximos do consumo, enquanto outras são transportadas a longas distâncias entre o local de origem e o de sua utilização.

Em síntese, o modelo inter-regional construído deriva de uma matriz nacional. As mercadorias são classificadas de acordo com o tamanho de seus mercados: para algumas mercadorias, o equilíbrio entre produção e consumo ocorre no nível local ou regional, enquanto, para outras, esse equilíbrio é atingido no nível nacional ou internacional.

O objetivo do modelo de Leontief-Hoffenberg é calcular, em etapas sucessivas, qual será a quantidade de cada mercadoria (regional e nacional) que deverá ser produzida em cada região, sendo dados os valores da demanda final. Para simplificar a necessidade de dados, o modelo utiliza uma matriz de coeficientes de distribuição que indica as diversas percentagens da produção de cada uma das mercadorias nacionais que serão atribuídas às diferentes regiões. Esses coeficientes supõem que os padrões locacionais de produção de todas as mercadorias nacionais são conhecidos e permanecem constantes. Dessa maneira, a distribuição da produção nacional entre as regiões de uma nação é dada, e uma expansão ou contração da produção se dão de forma proporcional para todas as regiões.

O modelo não apresenta equações de comportamento que permitam identificar os caminhos preferenciais que as mercadorias percorreriam no seu movimento entre as diversas regiões. É como se as mercadorias fossem colocadas num 
fundo nacional comum para serem retiradas pelos vários consumidores, sem referência específica às regiões de origem. Segundo Haddad (1976, p.225), essa é a razão básica pela qual este modelo de Leontief é denominado de intranacional e não de interregional.

Do ponto de vista empírico, os problemas conceituais e as dificuldades estatísticas, para classificar os diversos tipos de mercadorias e para obter uma hierarquia significativa de regiões, se destacam na implementação desse modelo. Contudo, sua aplicação mostra-se adequada quando não se sabe de antemão o padrão de localização de uma nova capacidade produtiva a ser instalada através de uma política de investimentos ou de comércio internacional. Nesse sentido, Leontief et al. (1965) utilizaram uma versão adaptada desse modelo para determinar o efeito sobre a composição industrial e a distribuição regional do emprego nos EUA, através da diminuição hipotética da demanda bélica.

\subsubsection{0 modelo de Leontief-Strout}

O modelo inter-regional de Leontief-Strout (1963) introduz equações de comportamento das exportações de mercadorias por origem e destino, sendo sua característica principal a utilização do modelo gravitacional para predizer fluxos interregionais de mercadorias. Pressupõe que as exportações de uma mercadoria de uma região a outra são diretamente proporcionais à sua produção total na região de origem e ao seu consumo total na região de destino e são inversamente proporcionais à distância entre as duas regiões.

No fundo, o modelo tem como base de predição a capacidade de produção e consumo de cada região, bem como seus custos de transferência de região para região. Assim, as matrizes com as quais é implementado o modelo não representam coeficientes de produção propriamente ditos, mas, sim, uma mistura de coeficientes de produção e distância.

Do ponto de vista empírico, essa forma de estimativa dos fluxos interregionais, além de exigir poucas informações estatísticas e de ser simples em sua 
operacionalização computacional, permite a existência de comércio simultâneo de uma mesma mercadoria entre duas regiões. Nesse sentido, Polenske (1970) fói quem realizou a primeira implantação completa desse modelo para a economia do Japão, com o objetivo de avaliar as repercussões econômicas na produção e fluxos de comércio da excessiva concentração de indústrias nas áreas que já eram mais desenvolvidas. Como não se dispunha de dados completos sobre os fluxos de comércio inter-regionais para 1963, o trabalho serviu apenas para avaliar os erros de estimativas na projeção das produções setoriais para o país e regiões.

\subsubsection{O modelo de Hansen e Tiebout}

O modelo foi apresentado pela primeira vez por Hansen \& Tiebout (1963) e se enquadra nos modelos-linha, enfocando a distribuição da produção regional que se destina ao mercado doméstico ou à exportação. Segundo seus coeficientes técnicos, a proporção do produto vendido pelas diversas regiões é a mesma, independentemente do nível de demanda das regiões compradoras.

Como Richardsom (1972, p.67) salientou, essa é uma suposição inaceitável, pois infringe o pressuposto walrasiano dos modelos de insumo-produto, segundo o qual variações no produto são causadas por mudanças na demanda e por variações nos preços por mudanças na oferta. Além disso, a utilização desse enfoque implica que os coeficientes de venda não sejam afetados pelas importações.

Polenske (1970) utilizou este modelo, entre outros, em seus estudos sobre a economia japonesa.

\subsubsection{O modelo de Chenery}

Este modelo, desenvolvido por Chenery (1953), tinha como objetivo básico analisar o impacto regional e nacional de políticas de investimento na Itália. Considera uma economia sem comércio internacional e parte do princípio de que são conhecidos os coeficientes de produção de cada região. No entanto, desconhece-se, para 
cada mercadoria produzida, quanto dos seus insumos são produzidos na região e quanto deles são produzidos em outras regiões, ou seja, a estrutura de abastecimento intra e inter-regional é desconhecida.

Chenery argumenta que, a partir das exportações e importações agregadas em nível regional, que são conhecidas, pode-se estimar a estrutura de abastecimento inter-regional em nível interindustrial, utilizando-se, para isso, no modelo proposto, uma matriz de coeficientes de abastecimento intra e inter-regional. Essa matriz é construída levando em consideração proporções fixas coluna: por exemplo, se um quinto do total de aço consumido pela região " $A$ " for proveniente da região " $B$ ", então, a todo o aço consumido em cada um dos setores produtivos de " $\mathrm{A}$ " será aplicado um coeficiente igual a 0,20 para destacar a parcela que se supõe seja importada de "B". A hipótese de Chenery indica, assim, que os coeficientes de abastecimento são iguais à participação de cada região nos fluxos intra e inter-regionais.

Esse pressuposto reduz significativamente o volume de informações necessárias para que seja implementado o modelo. Na operacionalização do modelo, são combinadas as matrizes de coeficientes de produção e as de coeficientes de abastecimento, que resultam numa matriz consolidada, parecida com a do modelo de Isard, do tipo que indica os fluxos de produção entre os diferentes setores das diferentes regiões do sistema econômico nacional.

Apesar de haver uma distinção fundamental entre os coeficientes de abastecimento de Isard e os de Chenery, ambos os modelos, ao projetarem os efeitos de alterações na demanda final sobre os setores produtivos de cada região, em condições ceteris paribus, utilizam o pressuposto de que as estruturas tecnológicas e de comércio entre as regiões permanecem constantes. Isso os torna muito próximos. É óbvio que será sempre possível incorporar ao modelo informações que indiquem mudanças nos processos técnicos de produção e nos padrões das transações inter-regionais, para que se possa trabalhar com coeficientes marginais diferentes dos coeficientes médios. Entretanto, esses coeficientes marginais teriam que ser estimados fora do modelo, por meio de técnicas de "calibragem" que ajustam os valores das linhas e das colunas da matriz $A$. 
No Brasil, uma aplicação deste modelo foi realizada por Haddad e Andrade (1974), com o objetivo de examinar a hipótese de que a substituição do antigo Imposto de Vendas e Consignações (IVC) para o atual Imposto de Circulação de Mercadorias (ICM) estaria prejudicando os estados menos desenvolvidos do país. $\mathbf{O}$ modelo possibilitou que a hipótese fosse rejeitada, bem como apontou, apesar da limitação dos dados disponíveis, que a hipótese de Chenery é consistente.

Cavalcanti (1994) também fez uso deste modelo para analisar a hipótese de Ter havidos mudanças estruturais na economia nordestina no período 1975-80, tendo obtido como resultado que, na verdade, não houve mudanças significativas na estrutura produtiva daquela região.

\subsection{Os modelos internacionais: alcance e limitações}

Se, para construir um modelo regional ou inter-regional, há necessidade de informações volumosas, na implementação de um modelo internacional, este problema se aprofunda ainda mais, na medida em que as estatísticas dos diferentes países diferem nos seguintes aspectos: a) classificação e agregação das estatísticas; b) base de dados e intervalos de tempo; c) disponibilidade de dados; d) consistência das estatísticas nos fluxos comerciais, etc.

Apesar desses problemas, os modelos internacionais, teoricamente, apresentam os mesmos alcances e limitações dos modelos inter-regionais analisados anteriormente; entretanto, em termos empíricos, observa-se que o sistema econômico, em geral, é representado com um número relativamente pequeno de setores, pois, para compatibilizar os dados das mais diversas fontes, os estudiosos são freqüentemente obrigados a construir matrizes insumo-produto multilaterais agregadas em poucos setores, o que não ocorre, necessariamente, com as matrizes regionais. Certamente, essa característica limita, de alguma maneira, a análise econômica direta em nível de produto, já que se faz necessário um estudo de caso através do desdobramento de seu setor específico. Contudo, em nível setorial, os alcances para analisar de forma integrada as relações comerciais entre países, blocos econômicos e as mais diversas políticas de 
cunho interno ou externo consagraram os modelos internacionais de insumo-produto como uma ferramenta de análise poderosa e confiável para a maioria dos estudosós.

$\mathrm{Na}$ Ásia, por exemplo, uma aplicação deste tipo de modelo foi aplicada por Furukawa (1986), com o objetivo de examinar o processo de substituição de importações e as relações interindustriais entre os países asiáticos e as economias norteamericana e japonesa. Os resultados, entre outros, indicaram que, para o crescimento econômico dos países asiáticos, existe uma grande dependência com as demandas finais dos Estados Unidos e do Japão. 


\section{METODOLOGIA DE CONSTRUÇÃO DO MODELO INSUMO-PRODUTO INTERNACIONAL DO MERCOSUL E SEU PROCESSO DE COMPILAÇÃO}

Como as próprias estatísticas dos dados disponíveis determinam aspectos centrais da orientação metodológica dos modelos insumo-produto, parece oportuno salientar estes aspectos. Para isso, este capítulo, tomando por base a classificação geral dos modelos insumo-produto discutidos no capítulo anterior, tem dois objetivos básicos: a) apresentar a estrutura teórica e de construção do modelo insumo-produto internacional proposto para o Mercosul e b) descrever brevemente seu processo de compilação para o ano de 1990.

\subsection{Considerações gerais sobre a seleção do modelo de construção}

A idéia de construir uma matriz insumo-produto internacional para o Mercosul está atrelada à necessidade de desenvolver um instrumental que permita, intersetorialmente, vizualizar os efeitos econômicos de seu processo de integração econômica. Isso porque, com a abertura regional dos mercados, a intensificação do comércio na região, associada às respectivas vantagens comparativas e economias de escala dos países, tende a modificar, aceleradamente, em todas as direções, a composição do consumo de insumos e produtos nacionais e importados.

Portanto, a questão a resolver é: qual dos tipos de modelos discutidos no capítulo anterior apresenta delineamentos mais adequados para a construção e implementação do modelo insumo-produto internacional do Mercosul?

De acordo com a classificação geral dos modelos inter-regionais e sua extensão para os modelos internacionais (Figura 4.1), o modelo a ser escolhido 
certamente deverá ser do tipo multilateral, uma vez que sua construção deve satisfazer, fundamentalmente, o objetivo de tornar clara a estrutura de transações interindustriais entre os países para que seja possível mensurar e qualificar os impactos econômicos da integração regional.

Nesse sentido, estabelecem-se três critérios básicos de seleção:1) nível de especificação elevado na estrutura intersetorial do modelo que permita testar políticas econômicas das mais diversas; 2), disponibilidade de dados estatísticos para sua implementação e 3) consistência com a teoria do equilíbrio geral.

Com base na Figura 4.1, três grupos de modelos convergem para a construção de modelos insumo-produto internacionais: a) os modelos que exigem dados diretos; b) os modelos regionais que derivam dos modelos nacionais; c) os modelos com estabilidade nos padrões de comércio.

No primeiro grupo, o modelo de Metzler esbarra no primeiro critério de seleção posto que sua estrutura não permite especificar setorialmente os efeitos interregionais para cada setor produtivo regional, ou seja, trata-se de um modelo agregado.

Já o modelo "ideal” de Isard não apresenta problemas de especificação, entretanto sua implementação com dados censitários é dificil uma vez que, em nível de Mercosul, só existem: a) matrizes insumo-produto individuais para a maior parte de seus países e b) dados sobre os fluxos de comércio inter-regionais (exportação e importação) por origem e destino em nível de países. Não se conhece, porém, a distribuição setorial desses fluxos nas estruturas de demanda intermediária e final de cada país parceiro. Portanto, apesar de ficar evidente que o modelo de Isard não atende ao segundo critério de seleção, na construção do modelo internacional para o Mercosul, esse será usado como o referencial teórico básico.

Quanto ao segundo grupo, os modelos intranacionais apresentam uma exigência de dados bastante crítica, além de que, neles, a dicotomia local-nacional não é muito realista porque a maioria das indústrias vende seus produtos em nível local e nacional. $\mathrm{Na}$ condição de um modelo insumo-produto, estes não preenchem todas as condições de um mercado de equilíbrio geral, visto que não determinam os fluxos de comércio inter-regional e não fazem referência às regiões de procedência das 
mercadorias. Desse modo, os modelos possuem problemas de especificação e consistência teórica, ou seja, não respeitam o primeiro e terceiro critério de seleção.

Portanto, a seleção do modelo restringe-se ao terceiro grupo, que se caracteriza por trabalhar com coeficientes fixos de comércio. Para o problema de falta de dados, os modelos inter-regionais deste grupo comumente apresentam, na construção de matrizes, hipóteses simplificadoras que impõem uma menor necessidade de informação.

Nesse sentido, os modelos na ótica gravitacional de Leontief-Strout tornam-se atrativos porque exigem poucas informações estatísticas. A estrutura de tais modelos, no entanto, apresenta problemas quanto à mensuração dos coeficientes de comércio, já que estes são funções de custos de transferência do produto de uma região para outra. Dessa maneira, os setores produtivos do modelo não fazem referência à origem dos insumos, desde que sejam idênticos; também os setores vendedores não especificam o destino de seu produto. Com base nessas considerações, pode-se afirmar que o modelo não obedece ao primeiro critério de seleção, ou seja, o da especificação intersetorial.

Quanto aos modelos tipo coeficiente linha de Hansen \& Teibuot, como já foi salientado anteriormente, estes infringem o critério de consistência teórica posto que consideram para todas as regiões uma mesma estrutura de demanda. Contudo, se este problema fosse superado, o que é factível (se a estrutura da demanda de cada país for diferente), certamente se constituíria num modelo adequado para o Mercosul, até porque exige poucos dados e a especificação setorial do modelo é elevada.

Por sua vez, os modelos da ótica de Chenery, conhecidos também como modelos coeficientes coluna, apesar de sua hipótese simplificadora ser considerada "forte", têm um uso flexível na medida em que podem ser utilizados somente em setores ou regiões com falta de dados, isto é, a hipótese não necessariamente tem que ser generalizada para toda a matriz insumo-produto. Cabe salientar, ainda, que o grau de especificação das relações interindustriais e a consistência teórica que o modelo apresenta permitem uma análise altamente desagregada do sistema econômico.

Portanto, de acordo com os critérios de seleção estabelecidos, o modelo proposto para o Mercosul tem como paradigma o modelo "ideal" de Isard, ainda que, 
neste caso, em virtude da limitação das informações, se utilize uma combinação das estruturas que apresentam as matrizes de importações de cada país com as hipóteses simplificadoras linha e/ou coluna. Em suma, trata-se de um modelo do tipo multilateral com características próprias, o qual se passa a descrever, em seqüência.

\subsection{0 modelo de insumo-produto multilateral, proposto para o Mercosul}

Considerando que, para definir uma área de integração econômica, são eliminadas as restrições tarifárias ao comércio intra-regional, sendo fixada uma tarifa externa contra terceiros países, pressupõe-se que o total da área geográfica dos países do Mercosul representa um sistema econômico unitário. Em conseqüência, as taxas de câmbio, os preços e os. custos de produção dos países permanecem constantes no período de análise.

Pressupõe-se que o modelo representa uma economia aberta na qual as exportações e importações de bens com países do restante do mundo são componentes da demanda final e da demanda intermediária, respectivamente.

Dadas as desigualdades existentes entre os países na tecnologia de produção, na distribuição espacial da população, renda, recursos, etc., assume-se, na linha de Isard, que há uma função de produção do tipo Leontief específica para cada região, isto é, cada país possui uma matriz insumo-produto individual. E, finalmente, pressupõe-se, em razão da integração espacial das economias, que os coeficientes de produção dependerão não somente da tecnologia utilizada e da estrutura de preços relativa, mas, também, da estrutura de abastecimento inter-regional em cada setor.

Nesse contexto, o quadro insumo-produto internacional para o Mercosul representa um sistema econômico mundial que especifica seis países (Argentina, Brasil, Bolívia, Chile, Paraguai e Uruguai), sendo outros países designados como o resto do mundo. A estrutura deste quadro multilateral é mostrada na Tabela 5.1. 
67

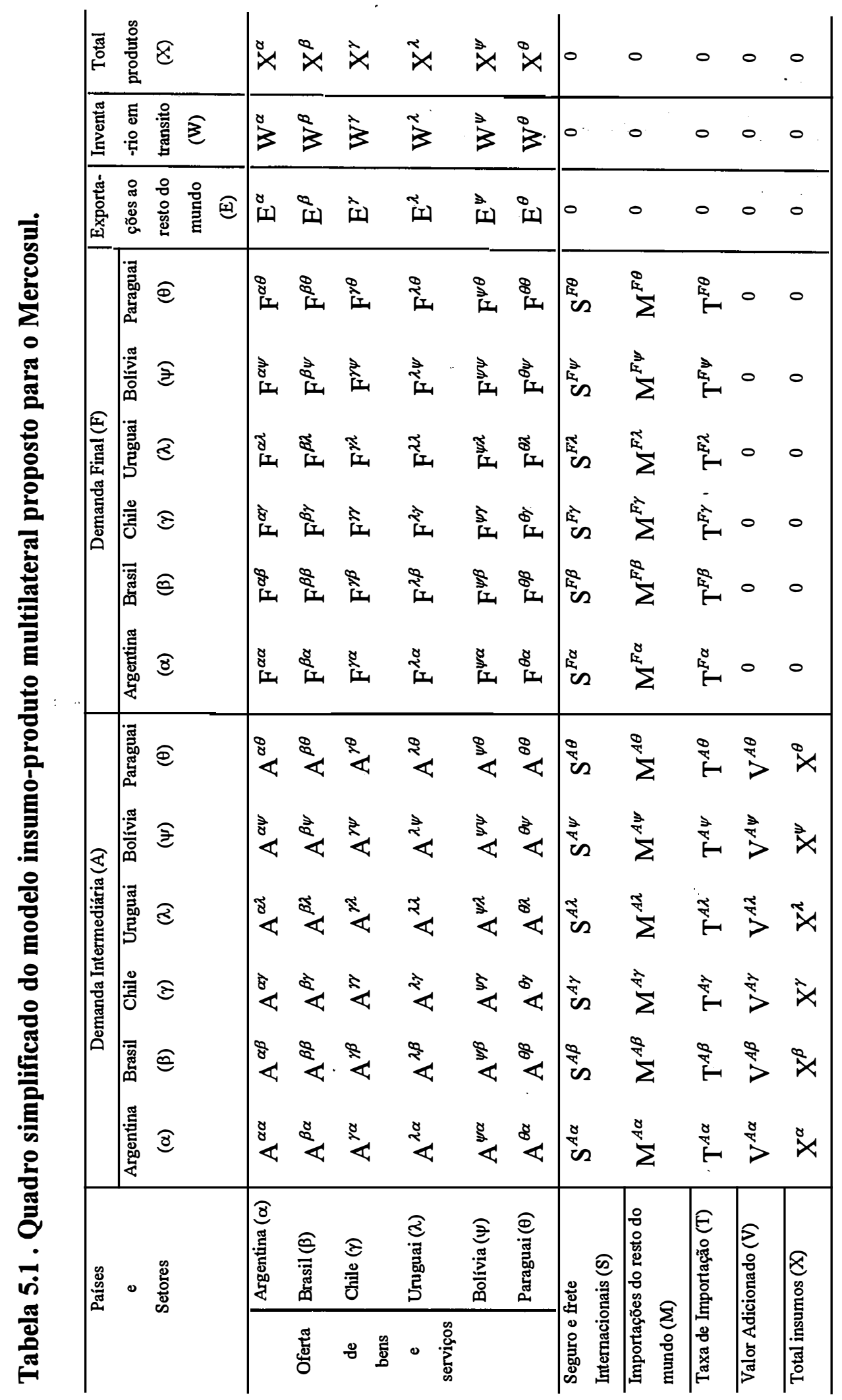


Nessa tabela, os setores de demanda localizados nas colunas são internacionalmente divididos em setores de demandas intermediárias (A), setores de demanda final $(F)$, setor do resto do mundo ou de exportações para o resto do mundo (E) e um setor de alterações no inventário em trânsito (W). Os setores de demanda intermediária e os setores de demanda final são subdivididos em Argentina ( $\alpha$ ), Brasil $(\beta)$, Chile $(\gamma)$, Uruguai $(\lambda)$, Paraguai $(\theta)$ e Bolívia $(\psi)$.

Por sua vez, os setores de suprimentos estão compostos pelo setor de seguros e frete internacional (S), setores de importações do resto do mundo (M), setor de taxas de importação (T) e um setor de valor adicionado (V). O setor de demanda intermediária e o setor de suprimentos de bens e de serviços são divididos entre os seis países em estudo.

Note-se que a tabela-resumo apresentada não mostra o número de setores industriais em cada país, pois esta questão será tratada em detalhes mais adiante. Entretanto, para fins didáticos, cabe mencionar que, no lado da demanda intermediária, as indústrias de cada país estão divididas em 31 setores comuns, e, no lado da demanda final, cada país apresenta $K=1,2,3$ e 4 setores consumidores. Por exemplo, a estrutura de insumos do setor industrial da Argentina, no bloco de transação $A^{\alpha \beta}$, mostra quanto as indústrias do Brasil compram das indústrias da Argentina, o que pode ser representado como $\sum_{i} \sum_{j} A_{i j}^{\alpha \beta}(i=1,2,3, \ldots, 31 ; j=1,2,3, \ldots, 31)$. Aqui, $i$ significa as indústrias da Argentina e $j$, as indústrias do Brasil. Similarmente, a quantidade de produtos que a indústria da Argentina ( $j$ ) comprou da indústria de Chile ( $i$ ) é representada como $A_{i j}^{\gamma \alpha}$. Dessa maneira, a estrutura de insumo para a indústria da Argentina (j) pode ser expressa através da seguinte relação contábil:

$$
X_{j}^{\alpha}=\sum_{i} A_{i j}^{\alpha \alpha}+\sum_{i} A_{i j}^{\beta \alpha}+\ldots+\sum_{i} A_{i j}^{\theta \alpha}+S_{j}^{A \alpha}+\sum_{i} M_{i j}^{A \alpha}+T_{j}^{A \alpha}+\sum_{n} V_{h j}^{A \alpha}
$$

onde:

$$
S_{j}^{A \alpha} \text { é o frete e o seguro internacional; }
$$


$M_{i j}^{A \alpha}$ são as importações da $j$-ésima indústria da Argentina do $i$-ésimo setor do resto do mundo;

$T_{j}^{A \alpha}$ é a taxa de importação paga pela j-ésima indústria da Argentina;

$V_{h j}^{A \alpha}$ é o $h$-ésimo componente de valor adicionado gerado pela $j$-ésima indústria da Argentina.

As estruturas de insumo das indústrias dos outros países também podem ser expressas de forma similar.

Quanto à estrutura da demanda para os produtos da indústria argentina (i), pode ser expressa através da seguinte relação contábil:

$$
X_{i}^{\alpha}=\sum_{j} A_{i j}^{\alpha \alpha}+\sum_{j} A_{i j}^{\alpha \beta}+\ldots+\sum_{j} A_{i j}^{\alpha \theta}+\sum_{K} F_{i K}^{\alpha \alpha}+\sum_{K} F_{i K}^{\alpha \beta}+\ldots+\sum_{K} F_{i K}^{\alpha \theta}+E_{i}^{\alpha}+W_{i}^{\alpha}
$$

onde:

$F_{i K}^{\alpha \beta}$ é a demanda final para o $i$-ésimo setor de produtos da Argentina através do $K$-ésimo setor (consumo das famílias, consumo do governo, formação de capital e variação de estoque) de demanda final do Brasil;

$E_{i}^{\alpha}$ são as exportações do $i$-ésimo setor da Argentina para o resto do mundo;

$W_{i}^{\alpha}$ representa o inventário em-trânsito do $i$-ésimo setor da Argentina.

As estruturas da demanda das indústrias dos outros países podem ser expressas de maneira similar.

Generalizando a estrutura de insumos para a j-ésima indústria do $q$-ésimo país $(q=\alpha, \beta, \gamma, \ldots, \theta)$, a equação (5.1) pode ser expressa da seguinte maneira:

$$
X_{j}^{q}=\sum_{r} \sum_{i} A_{i j}^{r q}+S_{j}^{A q}+\sum_{i} M_{i j}^{A q}+T_{j}^{A q}+\sum_{h} V_{h q}^{A q} \quad ; \quad \text { para } q \neq r
$$

onde $r=\alpha, \beta, \gamma, \ldots, \theta$ representa o $i$-ésimo setor do $r$-ésimo país em estudo. 
Simultaneamente à generalização da estrutura de demanda do $i$-ésimo setor, a equação (5.2) pode ser expressa da seguinte maneira:

$$
X_{i}^{r}=\sum_{q} \sum_{i} A_{i j}^{r q}+\sum_{q} \sum_{K} F_{i K}^{r q}+E_{i}^{r}+W_{i}^{r}
$$

Observe-se que as variáveis das equações (5.3) e (5.4) já foram definidas anteriormente. Assim, desde que o valor total de insumos utilizados seja igual ao valor total da produção $\left(X_{j}^{q}=X_{i}^{r}\right)$, o quadro insumo-produto multilateral será consistente.

Cabe salientar que, na matriz, o número de células no quadrante das relações interindustriais será igual ao número de setores multiplicado pelo número de países, uma vez que o modelo especifica a distribuição da produção de cada setor em cada país para os diversos setores de todos os países. Desse modo, o quadro simplificado do insumo-produto multilateral serve também de referência para a coleta de dados.

\subsubsection{Estimativa das relações interindustriais entre países parceiros}

De acordo com o quadro simplificado multilateral (Tabela 5.1), fica evidente que as importações de um país são as exportações do outro. As matrizes originais de cada país normalmente indicam, no lado da demanda intermediária, que os insumos comprados do $i$-ésimo setor pela $j$-ésima indústria estão decompostos em insumos domésticos $\left(A_{i j}^{d}\right)$ e insumos importados $\left(A_{i j}^{M}\right)$; pelo lado da demanda final, os produtos comprados do $i$-ésimo setor estão decompostos em produtos domésticos $\left(F_{i K}^{d}\right)$ e produtos importados $\left(F_{i K}^{M}\right)$.

Portanto, há necessidade de desagregar as matrizes de importação de insumos e produtos em dois níveis, transações interpaíses e transações com o resto do mundo, o que é válido também para o vetor de exportações de cada país. Mesmo porque as matrizes de bens importados não contemplam as relações interindustriais entre os diferentes países. $\mathrm{Na}$ verdade, com relação ao quadro simplificado multilateral, que, a rigor, representa o modelo "ideal"de Isard, só conhecemos as diagonais principais da 
demanda intermediária de insumos domésticos $\left(A^{d}\right)$ e insumos importados $\left(A^{M}\right)$ e a demanda final de produtos domésticos $\left(F^{d}\right)$ e produtos importados $\left(F^{M}\right)$, ou seja,

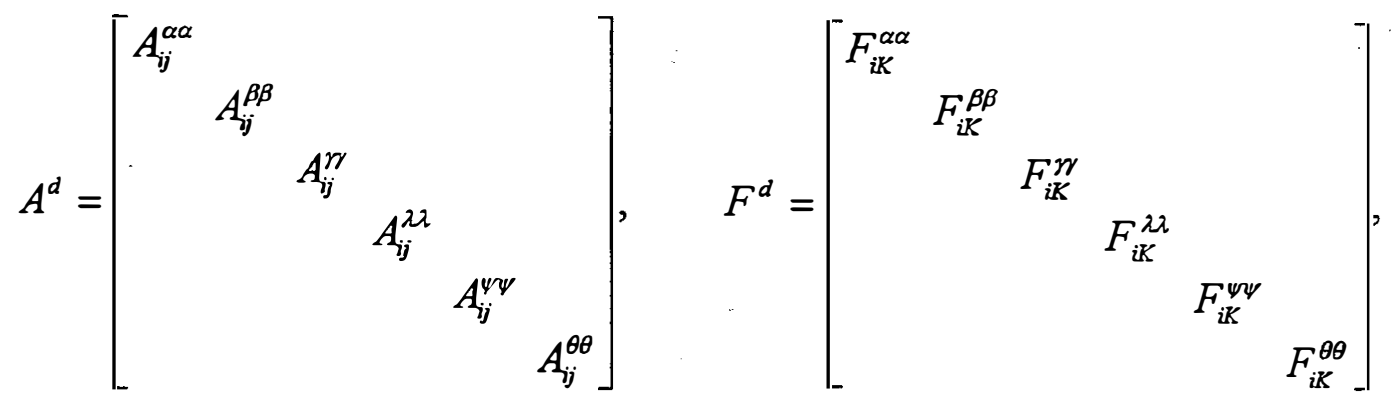

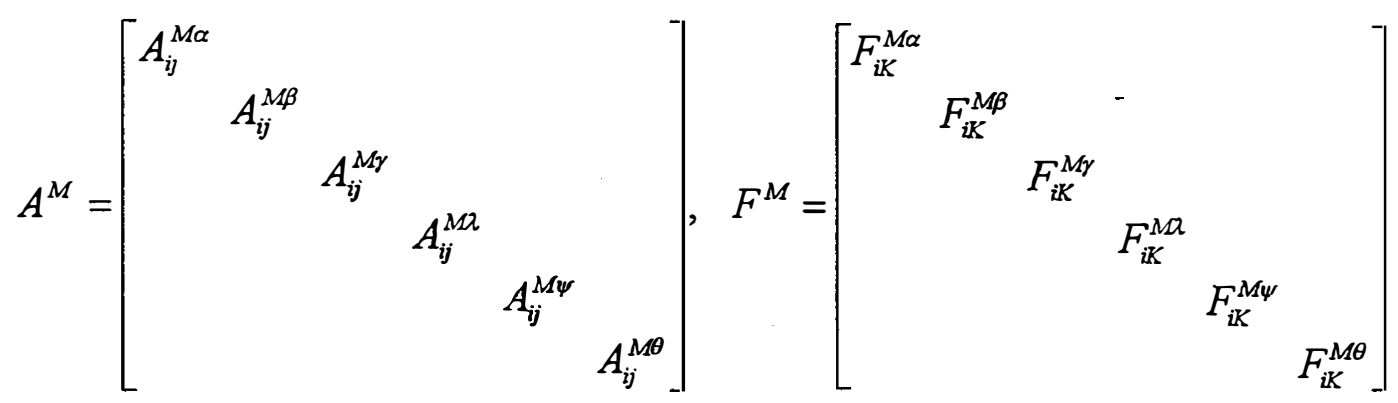

Desse modo, o problema crucial do sistema econômico a ser construído se resume em determinar quanto dos bens importados tem sua origem em cada país parceiro e qual é a distribuição desses bens entre as estruturas da demanda intermediária e da demanda final. É preciso, assim, determinar os blocos de transação tipo $A^{\beta \alpha}$, que representam, na Tabela 5.1, quanto as indústrias da Argentina importam das indústrias do Brasil no lado da demanda intermediária e os blocos tipo $F^{\beta \alpha}$, na Tabela 5.1, que indicam quanto dos bens exportados das indústrias do Brasil são destinados para a demanda final da Argentina.

Lembrando a classificação dos modelos de insumo-produto inter-regional e sua extensão para modelos de insumo-produto internacionais (Figura 4.1), o problema pode ser resolvido através de coeficientes-linha e/ou coeficientes-coluna, desde que se saiba quais as importações das $j$-ésimas indústrias argentinas que têm origem no $i$-ésimo setor do Brasil. Nesse sentido, é necessário propor uma hipótese sobre as fontes de 
abastecimento interpaíses que permita estimar a distribuição das exportações entre a demanda intermediária e a demanda final.

Utilizando como exemplo o bloco $A_{i j}^{\beta \alpha}$ da demanda intermediária, que indica as importações de insumos da indústria argentina $j$ originários da indústria do Brasil $i$, pressupomos que esses fluxos correspondem a um conjunto de proporções fixas, do tipo linha da matriz de importação total argentina, ou seja,

$$
A_{i j}^{\beta \alpha}=\hat{E}_{i}^{A \beta \alpha} \cdot B_{i j}^{A M \alpha} \quad \operatorname{com}(i=1,2,3, \ldots, 31 \text { e } j=1,2,3, \ldots 31)
$$

onde:

$$
\hat{E}_{i}^{A \beta \alpha} \text { é um vetor coluna de ordem (3Ixl) diagonalizado que representa as }
$$
exportações FOB do Brasil para Argentina, as quais são utilizadas como insumos;

$B_{i j}^{A M \alpha}$ é uma matriz de proporções linha, de ordem (31x31), que corresponde à estrutura da matriz de insumos importados consumidos pela demanda intermediária da Argentina.

$\mathrm{Na}$ equação (5.5), o vetor coluna de insumos exportados pelo Brasil para a Argentina é estimado da seguinte maneira,

$$
\hat{E}_{i}^{A B \alpha}=\hat{E}_{i}^{\beta \alpha} \cdot \frac{\hat{A}_{i}^{M \alpha}}{\hat{M}_{i}^{A F \alpha}}
$$

onde:

$\hat{E}_{i}^{\beta \alpha}$ é um vetor coluna de ordem $(31 \times 1)$ conhecido e diagonalizado, que representa o total de exportações (insumos e produtos) FOB do Brasil para Argentina;

$$
\hat{A}_{i}^{M \alpha} \text { é um vetor coluna de ordem }(31 \times 1) \text { diagonalizado que representa o }
$$

total CIF de insumos importados consumidos pelos setores da demanda intermediária argentina, ou seja, o consumo de insumos importados das indústrias argentinas $\left(\sum_{j} A_{i j}^{M \alpha}\right)$ 
$\hat{M}_{i}^{A F \alpha}$ é um vetor coluna de ordem $(31 \times 1)$ diagonalizado que expressa o total CIF de insumos e produtos importados consumidos, respectivamente, pelos setores da demanda intermediária e da demanda final argentina $\left(\sum_{j} A_{i j}^{M \alpha}+\sum_{j} F^{M \alpha}\right)$.

Ainda, na equação (5.5), a matriz de proporções linha de insumos importados pela Argentina é estimada da seguinte forma,

$$
B_{i j}^{A M \alpha}=\frac{A_{i i}^{M \alpha}}{\hat{M}_{i}^{A F \alpha}}
$$

onde $A_{i j}^{M \alpha}$ é uma matriz de ordem (31x31) que representa os insumos importados consumidos pelos setores ou indústrias da demanda intermediária argentina.

Note-se, na equação (5.5), quando o vetor diagonalizado $\hat{E}_{i}^{A \beta \alpha}$ prémultiplica a matriz $B_{i j}^{A M \alpha}$, que se está estimando a matriz de importações $A_{i j}^{\beta a}$ em preços FOB do país parceiro. Note-se, ainda, sendo conhecido o vetor de exportações, que indica o sentido do comércio de um país para outro, e utilizando-se como fator de ponderação a matriz de insumos importados, que se está preservando também a estrutura real da demanda intermediária de cada país. Portanto, fica evidente no modelo que a estrutura de demanda e de oferta de cada país é diferente.

Por sua vez, no bloco $F_{i K}^{\beta \alpha}$ da demanda final, os pressupostos e operacionalização para sua estimação são similares, de modo que

$$
\begin{gathered}
F_{i K}^{\beta \alpha}=\hat{E}_{i}^{F \beta \alpha} \cdot B_{i K}^{F M \alpha} \quad \operatorname{com}(i=1,2,3, \ldots, 31 \text { e } K=1,2,3,4) \\
\operatorname{com} \quad \hat{E}_{i}^{F \beta \alpha}=\hat{E}_{i}^{\beta \alpha} \cdot \frac{\hat{F}_{i}^{M \alpha}}{\hat{M}_{i}^{A F \alpha}} \quad \text { e } \quad B_{i K}^{F M \alpha}=\frac{F_{i K}^{M \alpha}}{\hat{M}_{i}^{A F \alpha}}
\end{gathered}
$$

onde: 
o termo $\hat{F}_{i}^{M \alpha}$ é um vetor coluna $(31 \times 1)$ diagonalizado que representa o total CIF linha de produtos importados consumidos pelos setores da demanda final da Argentina, $\sum_{K} F_{i K}^{M \alpha} \mathrm{e}$;

$B_{i K}^{F M \alpha}$ representa a estrutura de proporções linha da matriz de produtos importados pela demanda final da Argentina de ordem $(31 \times 4)$. Desse modo, $F_{i K}^{\beta \alpha}$ expressa as relações intersetoriais (matriz de importação) da demanda final entre os dois países a preços FOB.

Para que se mantenha consistência contábil entre as exportações e importações, deve ser respeitada a seguinte identidade para cada país parceiro:

$$
E_{i}^{\beta \alpha}=\sum_{j} A_{i j}^{\beta \alpha}+\sum_{K} F_{i K}^{\beta \alpha}
$$

ou seja, o total de exportações que o Brasil destina para a Argentina deverá ser igual à somatória das importações de insumos e produtos consumidos pela demanda intermediária e final, respectivamente, que a Argentina faz do Brasil.

Pelo exposto, fica evidente que as relações interindustriais deverão ser estimadas país a país. Oberva-se, ainda, que esse processo de estimação salienta a característica principal do modelo: as proporções de bens exportados pelos diversos países são diferentes de acordo com a estrutura de demanda de cada um deles. Desse modo, o pressuposto walrasiano dos modelos insumo-produto, segundo o qual variações no produto são causadas por mudanças na demanda e variações nos preços são causadas por mudanças na oferta, é respeitado. Esta característica, por sua vez, marca uma diferença fundamental com os modelos clássicos de coeficiente-linha de Hansen e Tiebout (1963), que não respeitam esse pressuposto de equilíbrio geral, sendo, por isso, criticados por Richardson (1972, p. 67). 


\subsubsection{Estimativa do frete e do seguro internacional}

Originalmente, as matrizes de importação de cada país têm como base de construção os preços CIF (cost insurance and freight: FOB + transporte internacional + seguro internacional) e as exportações dos países parceiros, os preços FOB (free on board: preço do produto colocado no navio, com o fornecedor arcando com-os custos referentes ao transporte da origem ao porto, além das taxas operacionais e burocráticas portuárias). Se as atividades de comércio exterior dos países fossem idênticas e se não houvesse inventário de bens em trânsito, certamente, a diferença direta dos relatórios de comércio entre os valores CIF e os valores FOB forneceria o valor do frete e do seguro internacional; porém, na prática, não ocorre isso.

$\mathrm{Na}$ verdade, existem atividades de comércio diferentes; existe descompasso entre as importações e as exportações; existem, às vezes, entradas falsas nos relatórios estatísticos; ainda, alguns bens exportados não são recebidos pelo país importador devido a acidentes em trânsito e, em casos de comércio entrepôt, o destino da exportação na declaração da importação pode não corresponder ao país produtor (Furukawa,1986, p.27). Tudo isso indica que, para a construção da matriz internacional do tipo multilateral, é importante que sejam preservadas o quanto possível as estruturas de insumos e produtos das matrizes de importações, que apresentam as matrizes nacionais dos países, visto que elas representam a parte real das economias e, sobretudo, a consistência contábil das estatísticas.

Nesse contexto, dada a inexistência de uma contabilidade do frete e do seguro internacional entre os países do Mercosul, que tenha por base a Classificação Uniforme de todas as Atividades Econômicas (CIIU) que as matrizes nacionais seguem, faz-se necessário estimar essas variáveis. Seguindo o exemplo das relações interindustriais entre a Argentina e o Brasil, as equações para esse propósito são as seguintes:

$$
A_{i j}^{S \beta \alpha}=A_{i j}^{\beta \alpha} \cdot t_{i}^{\beta \alpha} \quad \operatorname{com}(i=1,2,3, \ldots, 31 \text { e } j=1,2,3, \ldots 31)
$$




$$
F_{i K}^{S \beta \alpha}=F_{i K}^{\beta \alpha} \cdot t_{i}^{\beta \alpha} \quad \operatorname{com}(i=1,2,3, \ldots, 31 \text { e } K=1,2,3, \ldots 5)
$$

onde:

$A_{i j}^{S \beta \alpha}$ é a matriz de seguro e frete internacional (S) pago pelas $j$-ésimas indústrias argentinas, devido à demanda intermediária de insumos importados originários dos $i$-ésimos setores do Brașil;

$t_{i}^{\beta \alpha}$ representa a proporção do frete e do seguro internacional sobre os preços FOB que será acrescentada aos insumos e produtos que a Argentina importou do $i$-ésimo setor do Brasil;

$F_{i K}^{S B \alpha}$ representa o seguro e frete internacionais provenientes da demanda final argentina de produtos dos $i$-ésimos setores do Brasil. As demais variáveis já foram definidas anteriormente.

Observe-se que, para implementar as equações (5.8) e (5.9), tudo depende de que se obtenha a proporção $t_{i}^{\beta \alpha}$. Sob o particular, geralmente, sabe-se que as taxas de frete e de seguro têm, em média, $10 \%$ a $15 \%$ dos valores mundiais do preço FOB. Assim, se não existem censos nem estudos que especifiquem esses serviços numa região, por meio do tipo de bens e atividades ou do país que paga e recebe tais pagamentos, as matrizes multilaterais construídas para diferentes nações, como, por exemplo, as dos países asiáticos, utilizam-se, com freqüência, desses percentuais para estabelecer setorialmente o nível de seguros e frete internacional.

Nesse sentido, buscando-se trazer a realidade dos seguros e fretes pagos para a matriz do Mercosul, foi utilizada uma taxa média de $13 \%$ sobre os preços FOB, a qual se baseia em depoimentos de profissionais do setor aduaneiro e de agentes que participam de operações de comércio internacional. Desse modo, o total pago de seguro e frete internacional pela Argentina, pelas transações intermediárias $\left(S^{A \alpha}\right)$ e demanda final $\left(S^{F \alpha}\right)$ com os países parceiros será:

$$
S_{j}^{A \alpha}=\sum_{i} A_{i j}^{S \beta \alpha}+\sum_{i} A_{i j}^{S \gamma \alpha}+\sum_{i} A_{i j}^{S \lambda \alpha}+\sum_{i} A_{i j}^{S \psi \alpha}+\sum_{i} A_{i j}^{S \theta \alpha}
$$




$$
S_{j}^{F \alpha}=\sum_{i} F_{i K}^{S \beta \alpha}+\sum_{i} F_{i K}^{S \gamma \alpha}+\sum_{i} F_{i K}^{S \lambda \alpha}+\sum_{i} F_{i K}^{S \psi \alpha}+\sum_{i} F_{i K}^{s \theta \alpha}
$$

Por último, cabe salientar que, de acordo com Furukawa (1986, p.28), essa forma de estabelecer os seguros e fretes internacionais se mostra consistente, sendo, por isso, preferível a uma diferença direta dos preços CIF e dos preços FOB dos relatórios de comércio exterior.

\subsubsection{Reconciliação do quadro insumo-produto multilateral}

De acordo com a metodologia interindustrial descrita nos itens anteriores, são estimados, seqüencialmente: a) os blocos de transações domésticas de cada país, isto é, $A^{q q}$ e $F^{q q} \quad(q=\alpha, \beta, \gamma, \ldots, \theta$, símbolos usados na Tabela 5.1$) ;$ b) os blocos de transações de bens importados, isto é, $A^{r q}$ e $F^{r q}(r=\alpha, \beta, \gamma, \ldots \theta ; r \neq q)$ e c) os blocos dos custos de frete e seguro internacionais, isto é, $S^{A q}$ e $S^{F q}$.

Em continuação, com base nessas estimativas, os blocos das importações do restante do mundo a preços $\mathrm{CIF}$, tanto da demanda intermediária como da demanda final, podem ser estabelecidos por diferença:

$$
\begin{aligned}
& M^{A q}=A^{M q}-\left(A^{r q}+S^{A q}\right) \\
& M^{F q}=F^{M q}-\left(F^{r q}+S^{F q}\right)
\end{aligned}
$$

ou seja, as importações do restante do mundo no lado da demanda intermediária $\left(M^{A q}\right)$ serão iguais ao total de insumos importados $\left(A^{M q}\right)$ menos a somatória dos insumos importados entre os países parceiros $\left(A^{r q}\right)$ e os custos de frete e seguro $\left(S^{A q}\right)$ que isso implica. Para as importações de produtos, no lado da demanda final $\left(M^{F q}\right)$, o procedimento operacional será o mesmo. 
Do mesmo modo, o vetor das exportações para o restante do mundo, $E^{r}$, pode ser obtido pela diferença de dois vetores conhecidos: um que representa o total de exportações $\left(E^{r t}\right)$ e outro que expressa as exportações entre os países parceiros $\left(E^{r q}\right)$. Por sua vez, o bloco das tarifas e taxas de importação dos países, $T^{A q}$ e $T^{F q}$, e o bloco do valor adicionado $V^{q}$ para cada país são estabelecidos de forma direta, com base nas matrizes insumo-produto nacionais.

Considerando, entretanto, todos os blocos de transações, o balanço contábil entre a demanda total estimada $\left(X_{j}^{q}\right)$ não é, necessariamente, consistente com a estrutura de suprimento total de cada país $\left(X_{i}^{r}\right)$. Isso ocorre porque não foi considerada ainda a alteração do inventário em trânsito ocorrida durante o transporte de bens entre os países $\left(W^{r}\right)$. Assim, para que os dados de importação e de exportação sejam consistentes, deve ser seguida a seguinte equação entre blocos:

$$
A^{r q}+F^{r q}=E^{r q}+W^{r}
$$

isto é, a somatória das importações do comércio inter-regional de insumos $\left(A^{r q}\right)$ e produtos $\left(F^{r q}\right)$ deverá ser igual às exportações do comércio inter-regional $\left(E^{r q}\right)$ mais o inventário em trânsito $\left(W^{r}\right)$. Caso a estimativa exata de $W^{r}$ com base nas estatísticas oficiais seja impossível, na prática, este bloco é obtido a partir da seguinte equação:

$$
W^{r}=A^{r q}+F^{r q}-E^{r q}
$$

Note-se que as equações (5.14) e (5.15) dependem, fundamentalmente, da confiabilidade das estatísticas do mercado internacional, porém não há garantia de que não ocorram discrepâncias nos blocos $A^{r q}$ e $F^{r q}(\operatorname{com} r \neq q)$, que são estimados com base nas combinações das matrizes de importação de todos os países parceiros.

Nesse sentido, o bloco $W^{r}$ também representa uma variável de ajuste que inclui as discrepâncias nas estatísticas do mercado internacional dos países, assim como há margens de erro na estimativa dos blocos $A^{r q}$ e $F^{r q}$, visto que é extremamente raro 
que as estatísticas do mercado internacional de diferentes países sejam "consistentes dólar a dólar" umas com as outras. Contudo, como é impossível a construção de uma matriz multilateral com tal grau de precisão, a magnitude dos valores de uma coluna ou linha de ajuste indicará o nível de erros e de discrepância estatística existente.

\subsubsection{Fechamento do modelo multilateral}

Uma vez concluída a construção da matriz insumo-produto do Mercosul, suas informações permitem estimar coeficientes do tipo:

$$
a_{i j}^{\alpha \beta}=\frac{A_{i j}^{\alpha \beta}}{X_{j}^{\beta}}
$$

os quais indicam a participação do insumo $i$, produzido na Argentina ( $\alpha$ ), por unidade de produção do $j$-ésima indústria do Brasil $(\beta)$. Em conjunto, esses coeficientes formaram a matriz $A$

$$
A=\left[\begin{array}{cccc}
a_{i j}^{\alpha \alpha} & a_{i j}^{\alpha \beta} & \cdots & a_{i j}^{\alpha \theta} \\
a_{i j}^{\beta \alpha} & a_{i j}^{\beta \beta} & \cdots & a_{i j}^{\beta \theta} \\
\vdots & \vdots & \cdots & \vdots \\
a_{i j}^{\theta \alpha} & a_{i j}^{\theta \beta} & \cdots & a_{i j}^{\theta \theta}
\end{array}\right] \quad(i, j=1,2,3, \ldots, 31)
$$

Essa matriz indica, simultaneamente, a estrutura tecnológica de cada país e a estrutura de abastecimento interpaíses. Por exemplo: qual será o coeficiente técnico de produção do setor $j=4$ da Argentina $(\alpha)$ em suas relações interindustriais (coluna) com o setor $i=3$ de seus países parceiros $\alpha, \beta, \delta, \gamma, \psi$ e $\theta$, ou seja, $a_{34}^{\alpha}$ ?

Para obter esse coeficiente, faz-se necessário o seguinte procedimento: calcular os coeficientes da participação do setor $i=3$ dos diferentes países no abastecimento do setor $j=4$ da Argentina $(\alpha) a_{34}^{\alpha \alpha}=\frac{A_{34}^{\alpha \alpha}}{X_{4}^{\alpha}} ; a_{34}^{\beta \alpha}=\frac{A_{34}^{\beta \alpha}}{X_{4}^{\alpha}} ; \ldots ; a_{34}^{\theta \alpha}=\frac{A_{34}^{\theta \alpha}}{X_{4}^{\alpha}}$ 
e somar os coeficientes abastecimento $a_{34}^{\alpha}=a_{34}^{\alpha \alpha}+a_{34}^{\beta \alpha}+\ldots+a_{34}^{\theta \alpha}$. O coeficiente técnico de produção $a_{34}^{\alpha}$ indica quantos centavos de insumos do setor $i=3$ são necessários por dólar de produção do setor $j=4$ do país $\alpha$, independentemente de se saber em que país foi produzido o insumo $i=3$.

Utilizando a matriz $A$ e o quadro simplificado do Mercosul, de forma análoga ao modelo básico de Leontief, pode-se representar o sistema de equações da seguinte forma:

$$
\sum \sum a_{i j}^{r q} X_{j}^{q}+F_{i}^{r}=X_{i}^{r}
$$

$\operatorname{com} i, j=1,2,3, \ldots 31 \mathrm{e} ; \quad r, q=\alpha, \beta, \ldots \theta$ alternativamente

Ou pode ser descrita também como

$$
X_{i}^{r}-\sum \sum a_{i j}^{r q} X_{j}^{q}=F_{i}^{r}
$$

A equação (5.18b) indica, por exemplo, a produção do setor $i$ do país $\alpha$ e a demanda intermediária dos 31 setores produtivos dos países $\alpha, \beta, \ldots, \theta$, ou seja,

$$
X_{i}^{\alpha}=F_{i}^{\alpha}+\sum_{j=1}^{31} a_{i j}^{\alpha q} X_{j}^{q} \quad \text { com } \quad q=\alpha, \beta, \ldots \theta
$$

Fatorizando a equação (5.19), esta pode ser expressa em termos dos componentes da demanda final, isto é:

$$
X_{i}^{r}=\left(I-\sum \sum a_{i j}^{r q}\right)^{-1} \cdot F_{j}^{q} \text { sendo }\left\{\begin{array}{l}
i, j=1,2,3, \ldots, 31 \\
r, q=\alpha, \beta, \ldots \theta
\end{array}\right.
$$

ou 


$$
X_{i}^{r}=\sum_{q} \sum_{j} b_{i j}^{r q} \cdot F_{j}^{q}
$$

onde $b_{i j}^{r q}$ é um elemento da matriz inversa de Leontief $\left(I-\sum \sum a_{i j}^{r q}\right)^{-1}$ e indica os requisitos diretos e indiretos de produção do setor $i$ dos países $q$, por unidade de demanda final à atividade $j$ no país $r$.

Finalmente, note-se que a demanda final do modelo é exógena, o que permite que se analisem de forma sistêmica o perfil das estruturas de transações, diferentes tipos de problemas que envolvem efeitos de transbordamento interpaíses, programas de investimentos, aumento do consumo, tributação, mudança tecnológica, etc.

\subsection{Processo de compilação do quadro insumo-produto multilateral do Mercosul}

Os dados necessários para a implementação do modelo insumo-produto do Mercosul são de natureza secundária e incluem as matrizes insumo-produto de cada país, o nível de importação e exportação por origem e destino interpaíses e com o resto do mundo; o valor bruto da produção setorial dos países; taxas de câmbio nacionais, etc. Em geral, as estatísticas utilizadas representam as últimas informações disponíveis em matéria de insumo-produto de cada país. Nesse sentido, o presente estudo, baseado nas fontes empregadas, tem o grau máximo de atualização possível.

Como ficou evidente que as próprias características dos dados disponíveis determinam aspectos centrais da orientação do trabalho, considera-se oportuno explicar tais aspectos. Para isso, como forma de sistematizar a heterogeneidade e o volume elevado de informações de cada país, inicialmente, descrevem-se os aspectos centrais das estatísticas utilizadas e, num segundo momento, estabelece-se uma compatibilização e classificação uniforme setorial comum dos dados. 


\subsubsection{Diretrizes comuns das estatísticas}

As matrizes de insumo-produto utilizadas neste trabalho representam o panorama mais detalhado sobre a oferta e a demanda de bens e serviços que incluem relações intersetoriais das diversas atividades econômicas. Tendo em vista o especial esforço que demanda a definição das variáveis que fazem parte das atividades, bens e serviços e a mensuração dos fluxos de oferta e demanda, só é possível desenvolver pesquisas para a construção de matrizes insumo-produto nacionais a cada certo número de anos. Dessa maneira, as diretrizes internacionais das Nações Unidas, que sugerem sua realização no máximo a cada década, apesar de salientarem a necessidade de sua elaboração a cada qüinqüênio, nem sempre foram cumpridas plenamente pelos países do Mercosul na medida em que os recursos financeiros não o permitiram.

Cabe, porém, observar que as matrizes insumo-produto dos países do Mercosul podem ser compatibilizadas entre si já que estabelecem suas bases conceituais, definições, classificação, coerência contábil e econômica nas diretrizes das Nações Unidas, as quais são indispensáveis para que se iniciem e implementem estudos empíricos na área.

\subsubsection{Definição da unidade de preços no sistema econômico}

As matrizes insumo-produto disponíveis em cada país nem sempre coincidem com as unidades de preços, sendo publicadas ou a preços básicos, ou a preços de produtor, ou a preços de consumidor. A questão é, então, que unidade de preço deverá ser usada na matriz do Mercosul?

Se a análise de insumo-produto pretende avaliar a quantidade de produção induzida pelas demandas finais, uma matriz estimada a preços de consumidores não é a mais adequada para a definição de coeficientes de insumo já que a estabilidade destes é quebrada. Isso porque o preço ao consumidor inclui margens de comercialização e custos de transporte (Furukawa, 1986, p.12). Por essa razão, as matrizes insumo-produto estimadas são apresentadas a preços básicos ou a preços do produtor. 
A tendência da literatura, entretanto, a partir da década de 1980, assinala que as matrizes a preços básicos são mais populares porque simplesmente consideram as despesas com matéria-prima e mão-de-obra, deixando de lado as cargas tributárias relacionadas com a produção e a dupla contagem que isso implica.

As matrizes de insumo-produto internacionais do tipo multilateral têm acompanhado essa tendência, porém é freqüente observar, em sua implementação, a utilização alternativa de matrizes nacionais com unidades de preço diferentes. Certamente, isso ocorre pela indisponibilidade de ourras estatísticas e se justifica desde que se leve em consideração que a análise econômica através do instrumental insumoproduto nunca pretendeu resultados absolutos. Entretanto, o bom senso indica que, quanto mais se possa evitar o uso de unidades de preço diferentes, melhor será.

Nesse sentido, a matriz multilateral do Mercosul é construída, na medida do possível, a preços básicos, para que se possa captar com melhor clareza as mudanças na produção dos diferentes países.

\subsubsection{Definição da unidade monetária e ano-base do sistema econômico}

Como a matriz internacional contém as matrizes nacionais de diferentes moedas, fez-se necessária a conversão de seus valores em uma moeda comum. Assim, para a matriz do Mercosul, foi usado o dólar americano como a moeda comum para todos os países. Os índices utilizados para esse processo foram as taxas de câmbio médias de cada país (Tabela 5.2).

Espera-se que a definição dos anos-base para a construção de cada matriz nacional obedeça a mudanças significativas nas estruturas econômicas, porém, na prática, essa decisão está condicionada à conjuntura econômica, à disponibilidade de recursos e à dinâmica de projetos complementares de insumo-produto. Em conseqüência, o ano-base de elaboração das matrizes nacionais não coincide, já que estas são desenvolvidas a intervalos de tempo diferentes.

Fica evidente, assim, que as possibilidades de eleição de um ano-base comum para todos os países são consideravelmente limitadas e, mais ainda, quando se 
busca que a implementação da matriz multilateral coincida com a maior disponibilidade relativa de dados e com o início das negociações da formação do Mercosul no ano de 1990.

Tabela 5.2 . Taxa de câmbio do dólar americano médio corrente (rf) em cada país e Índice de Precos ao Atacado dos Estados Unidos.

\begin{tabular}{llccc}
\hline Anos & Países & $\begin{array}{c}\text { Taxa de câmbio } \\
\text { média }\end{array}$ & $\begin{array}{c}\text { Relação de moedas } \\
\text { Indice preço atacado. USA } \\
(1990=100)\end{array}$ \\
\hline 1983 & Uruguai & 34,54 & Novo Peso/\$USA & 87,1 \\
1984 & Argentina & 0,00000676 & Peso/\$USA & 89,2 \\
1986 & Chile & 193,016 & Peso/\$USA & 86,2 \\
1990 & Brasil & 68,30 & Cruzeiro/\$USA & 100,0
\end{tabular}

Fonte: Estatísticas Financeiras Internacionais. Anuario de 1992, 1993 e 1994. Fundo Monetário Internacional, 1995.

Julgou-se conveniente, contudo, para a construção da matriz do Mercosul, estabelecer o ano-base de 1990, pelas seguintes justificativas: a) na literatura econômica, encontra-se que, na década de 1980, não ocorreram mudanças significativas nas economias da região; b) da perspectiva do insumo-produto, as matrizes nacionais correspondem a anos bastante próximos e, em média, têm como ano-base o segundo qüinqüênio da década de1980; c) a matriz nacional mais importante do Mercosul (Brasil representando mais do 79\% do sistema econômico) tem como base o ano de 1990.

Em síntese, argumenta-se que as estruturas interindustriais de cada país para o ano de 1990 são compatíveis; por isso, não foi preciso atualizar as estruturas interindustriais das matrizes nacionais ${ }^{32}$. Entretanto, para que as matrizes nacionais apresentem dados contemporâneos, optou-se por atualizar seus valores através do Índice de Variação de Preços ao Atacado do Mercado Americano (Tabela 5.2). Finalmente, deve-se salientar que, após a realização desse conjunto de operações, as discrepâncias estatísticas entre exportações e importações foram pequenas (ver Apêndice 1 coluna 144 da Tabela A1.5).

32 Se necessária essa atualização, a indisponibilidade de estatísticas confiáveis, tempo e, fundamentalmente, recursos financeiros inviabilizariam esse processo no curto e médio prazo. 


\subsubsection{Aspectos específicos das matrizes nacionais}

As informações elaboradas e publicadas pelos órgãos oficiais de cada país apresentam particularidades específicas que salientam aspectos mais importantes de suas economias, sendo, por isso, importante uma breve descrição desses dados.

A matriz insumo-produto da Argentina foi elaborada para o ano de 1984 pela Dirección Nacional de Análisis e Proyecciones Sectoriales da Subsecretaría de Programación del Desarrollo e publicada em 1989. Algumas estruturas setoriais de oferta e demanda utilizadas, entretanto, datam de 1986 e 1987. As informações básicas da matriz foram as Contas Nacionais da Argentina de 1985 (BCA, 1986).

As informações publicadas correspondem a dois volumes: um que trata dos produtos nacionais e o outro, dos produtos importados. Os dados estão em mil pesos de 1984, e a construção da matriz é do tipo enfoque setor por setor a preços de produtor. As dimensões das matrizes são de 218 por 218 setores, e a metodologia de sua elaboração corresponde a um conjunto de documentos produzidos pela Secretaria de Planificación do BCA (BCA, 1986), que correspondem às matrizes insumo-produto de 1963 e 1973.

No caso brasileiro, a matriz insumo-produto data do ano de 1990 e foi elaborada pelo Instituto Brasileiro de Geografia e Estatística (IBGE) com base nos dados das Contas Nacionais do Brasil de 1990 (IBGE, 1996). O total de informações publicadas engloba um conjunto de vinte tabelas, cujos dados estão em milhões de cruzeiros de 1990; as diferenças eventualmente encontradas entre as tabelas decorrem de arredondamentos.

As informações são apresentadas numa abordagem do tipo enfoque produto por setor a preços básicos, permitindo que cada produto seja produzido por mais de um setor e que cada setor produza mais de um produto, ou seja, existe uma matriz de produção e outra de insumos, chamada também de uso. A dimensão da matriz de produção é de 46 setores por 81 produtos e a da matriz de uso, de 81 produtos por 46 setores. Essa metodologia de tratamento dos dados está estabelecida num conjunto de 
documentos produzidos pelo Departamento de Contas Nacionais do IBGE (IBGE, 1979, 1984, dez. 1988, 1989, jul. 1991 e 1995).

A matriz de insumo-produto para a economia chilena corresponde ao ano de 1986 e foi elaborada pela Gerência de Divisão de Estudos do Banco Central de Chile (GDE/BCC), com base nas estatísticas sobre as contas nacionais e tributações do imposto ao valor agregado e renda do Instituto Nacional de Estatísticas (INE) e Serviços de Impostos Internos (SII), respetivamente (BCC, 1992).

$\mathrm{O}$ total de informações publicadas soma trinta e cinco tabelas, cujos dados estão em milhões de pesos de 1986. A dimensão da matriz de produção é de 75 setores por 75 produtos; da matriz de uso, de 75 produtos por 75 setores.

As matrizes têm uma apresentação sob o enfoque setor por produto a preços básicos, permitindo que cada setor produza mais de um produto e que cada produto seja produzido por mais de um setor. Toda a metodologia de tratamento dos dados está exposta na própria publicação da matriz de 1986 (BCC, 1992).

A matriz de insumo-produto do Uruguai corresponde ao ano de 1983 e foi elaborada pelo Banco Central do Uruguai (BCU) com base nas Contas Nacionais do Uruguai de 1983 (BCU, 1991). As informações são apresentadas numa abordagem do tipo setor por setor, a preços de comprador, com tecnologia baseada na indústria, ou seja, os preços incorporam preços básicos, impostos de comercialização e margens de comércio. $\mathrm{O}$ total de informações publicadas abrange nove tabelas, e a dimensão das matrizes é de 55 por 55 setores. Note-se que o fato da matriz ser construída com o enfoque setor por setor faz com que não existam as matrizes de produção e de uso, ou seja, elas já estão incorporadas nessa abordagem.

\subsubsection{Compatibilização, classificação e agregação setorial uniforme}

Todas as matrizes foram transformadas para o enfoque tecnológico original de Leontief, setor por setor, com tecnologia baseada na indústria, ou seja, cada setor produz um único produto e cada produto é produzido por um único setor. Para isso, 
fez-se uso das metodologias conhecidas na literatura apresentadas no capítulo 5 , de Miller e Blair (1985), e no capítulo 2, de Dixom et al. (1992).

Dada a relativa importância que cada atividade econômica representa para cada país, alguns subitens aparecem publicados desagregados de seus setores correspondentes, o que deixa em evidência a heterogeneidade das informações básicas. Verificou-se também que alguns setores originais das matrizes não podiam ser desagregados em um nível maior, fundamentalmente porque os dados necessários para isso eram indisponíveis, especialmente no referente às estruturas de demanda. Para solucionar esses problemas, optou-se por um nível de agregação setorial maior em todos os países, de forma que se obtivesse para cada país uma matriz ( $\boldsymbol{n} \times \boldsymbol{n}$ ) na qual os setores correspondentes às linhas e colunas fossem comuns. Assim, quando da estimação dos coeficientes inter-regionais, foi possível obter o máximo de relações intersetoriais de um país com os diferentes setores dos diferentes países.

Para facilitar a agregação ou desagregação consistente das matrizes insumo-produto nacionais, foram necessárias uma compatibilização e classificação setorial uniforme específicas para o Mercosul. $\mathrm{Na}$ compatibilização setorial, foram utilizadas as tabelas que correlacionam a Nomenclatura da Associação LatinoAmericana de Integração (Naladi) e a Classificação Industrial Internacional Uniforme de todas as atividades econômicas (CIIU-Rev.2). A classificação setorial objetivou simplificar a leitura das matrizes e salientar os setores mais importantes das economias, o que coincidiu num nível de agregação de 31 setores. Desse modo, os critérios usados na implementação da matriz multilateral resumiram-se a três: a) manter as características básicas das classificações originais das matrizes insumo-produto nacionais que obedecem a diretrizes básicas da CIIU-Rev.2; b) reduzir o número de setores para 31; c) salientar as características do mercado internacional do Mercosul, deixando desagregados setores mais importantes.

Feitas todas essas considerações gerais sobre as informações utilizadas, deve-se salientar que a matriz insumo-produto internacional construída para o Mercosul1990, que representa um sistema econômico mundial, não especifica as economias da Bolívia e do Paraguai, pois as informações necessárias para sua especificação no 
sistema, tais como as matrizes insumo-produto nacionais e matrizes de importação, no caso boliviano, não estão disponíveis e, no do Paraguai, não existem. Entretanto, como estes dois países em conjunto representam apenas $1,72 \%$ do produto total da economia do Mercosul, os resultados provavelmente não foram afetados em sua essência, até porque os fluxos de comércio desses países com a Argentina, Brasil, Chile e Uruguai estão considerados no que foi denominado de resto do mundo.

No Apêndice 1, é listada a classificação setorial da demanda intermediária e da demanda final, a descrição sucinta das linhas e colunas da matriz insumo-produto, apresentando-se, finalmente, a matriz insumo-produto internacional do Mercosul para 1990. 


\section{O PERFIL DAS ESTRUTUTAS DE TRANSAÇÕES INTERNACIONAIS E OS SETORES-CHAVE NA ECONOMIA DO MERCOSUL EM 1990}

O estudo dos processos de interdependência das relações intersetoriais do Mercosul se justifica, na medida em que permite identificar os possíveis efeitos econômicos de determinadas ações públicas e privadas sobre as estruturas de produção de um ou mais países. Porém, dada a abrangência dessas interdependências em um sistema econômico, torna-se necessário delimitar um campo analítico próprio para o problema.

A teoria do insumo-produto atende a essa necessidade analítica, e seu quadro simplificado, que apresenta propriedades sistêmicas (como dependência e independência, hierarquia e circulação entre setores), constitui-se na base empírica fundamental para identificar as ligações intersetoriais mais importantes para o desenvolvimento econômico dos países. Faz-se, então, necessário caracterizar no Mercosul: a dimensão econômica dos mercados e o perfil das estruturas de ransações internacionais dos países; as ligações industriais e os setores-chave.

Nesse sentido, o objetivo básico que norteia o desenvolvimento deste capítulo centra-se na identificação dos padrões de comportamento intersetoriais das economias, considerando o Mercosul como um só espaço econômico.

\subsection{A dimensão econômica e o perfil das estruturas de transações internacionais}

Um dos propósitos da análise de insumo-produto é o esclarecimento das relações que se estabelecem com o comércio internacional, entre a estrutura industrial e a estrutura de mercado dos diferentes países. Isso porque a interdependência comercial 
faz com que as indústrias de um dado país usem bens importados como insumos, mesmo que estes estejam disponíveis domesticamente, acarretando a realocação da produção em diversas direções.

Certamente, para que ocorram as transações comerciais e, em conseqüência, se estabeleça a competição pelo mercado internacional, deve existir, entre outros fatores, diferença no preço de algum bem em questão. Porém, dadas as mudanças traumáticas que podem ocorrer nas estruturas produtivas por causa do comércio internacional, os países tomam várias medidas para restringir e até proibir importações. A razão fundamental disso é simples: buscam proteger as indústrias domésticas, ainda que se saiba que, a médio e longo prazo, com a queda das barreiras, a estrutura de algum mercado internacional predominará com suas mercadorias, mesmo porque o protecionismo, que implica o sacrifício da renda nacional no tempo, torna-se insustentável.

Para analisar esses processos, os mercados predominantes e os não predominantes podem ser incorporados numa matriz de insumo-produto internacional; contudo, pelo fato de este instrumental não relacionar as estruturas de mercado com as estruturas industriais, não é possível abordar esse tipo de problema de forma direta. Considerando, entretanto, que, na matriz de insumo-produto internacional, os mercados e as indústrias estão ligados através de coeficientes técnicos de insumo, é possível, do ponto de vista da dimensão econômica, visualizar a estrutura do mercado como uma conseqüência lógica das atividades de produção existentes e a estrutura industrial (ou tecnologia industrial) como um determinante dos fluxos de comércio.

Sob essa perspectiva, as transações entre as indústrias dos países do Mercosul em 1990, resumidas na Tabela 6.1, mostram as demandas intermediárias por insumos e as demandas finais por produtos de um setor por país. Essas informações permitem, inicialmente, que se estabeleçam alguns parâmetros sobre a dimensão econômica dos mercados a fim de caracterizar as situações mais prováveis do comportamento dos agentes econômicos. 


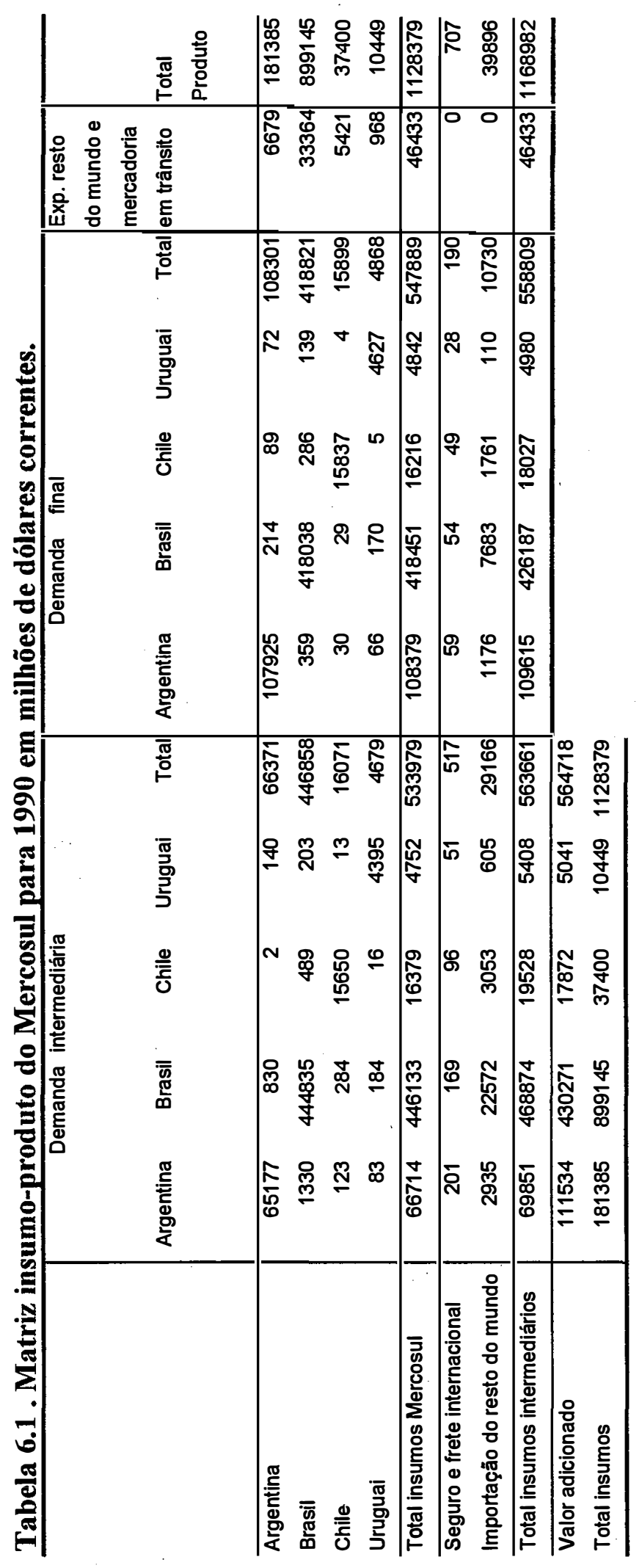


A dimensão econômica, entendida como a capacidade de mercado que representa uma economia nacional, traz implícita a idéia macroeconômica de que o tamanho do mercado permite o uso de tecnologias produtivas direcionadas para magnitudes cada vez maiores. Assim, dependendo da dimensão econômica individual ou em conjunto dos países, as possibilidades de desenvolvimento da indústria, do comércio e da capacidade de negociação serão maiores ou menores

Nesse sentido, segundo Salgado $\left(1990\right.$, p.164) ${ }^{33}$, variáveis, tais como o PIB, a população, o PIB per capita, a estrutura setorial do produto, o valor adicionado, o grau de abertura do mercado e a estrutura da demanda, constituem-se em indicadores "proxi" da dimensão econômica dos países. Com base nisso, para a presente análise, serão usados o valor adicionado e a população, variáveis com as quais se visa caracterizar as situações mais prováveis da demanda potencial dos mercados no marco de um mercado comum

Observa-se, na Tabela 6.1, que a dimensão econômica relativa dos países do Mercosul, estabelecida pelo valor adicionado, indica, para 1990, que a Argentina, o Chile e o Uruguai, em relação ao Brasil, representam 19,75\%, 3,16\% e 0,90\%, respectivamente. A integração econômica desses países - que implica a eliminação de tarifas ao comércio inter-regional e a harmonização tributária destinada a igualar as legislações, os impostos e as práticas comerciais - evidencia que a ampliação do potencial do mercado é extremamente desigual; em conseqüência, a criação e a implementação de uma base competitiva comum para os agentes econômicos, na qual a distribuição dos "custo e beneficios" seja eqüitativa, tornam-se dificeis. Isso porque, por exemplo, com base na população de $1990^{34}$, percebe-se que a ampliação do potencial dos mercados foi da ordem de: para a Argentina, 5 vezes; para o Brasil, 32,87\%; para o

33 Chama-se-a atenção para algumas variáveis básicas do processo de integração entre países em desenvolvimento, com as quais se estabelece, em função da dimensão econômica e o grau de industrialização, quais são suas motivações econômicas principais para envolver-se na união de suas economias, isto é, dentro de um processo de integração, os países não necessariamente perseguem os mesmos objetivos; tudo dependerá do nivel de desenvolvimento econômico que, individualmente, apresentem.

${ }^{34}$ Segundo o Anuário Estatístico de América Latina e o Caribe de 1991 da Cepal, a população dos países do Mercosul em 1990 era: Argentina, 32,55 milhões; Brasil, 148,48 milhões; Chile 13,17 milhões e Uruguai, 3,09 milhões. 
Chile, 14 vezes e, para o Uruguai, 63 vezes. Já, com base no valor adicionado, foi: para a Argentina, 4 vezes; para o Brasil, 31,25\%; para o Chile, 30 vezes e, para o Uruguai 111, vezes.

Com esses indicadores e considerando que o efeito inicial derivado de um processo de integração econômica é a ampliação da demanda inter-regional resultante do incremento do número de consumidores, pode-se argumentar, num primeiro momento, que as oportunidades relacionadas à demanda parecem substancialmente maiores para as outras economias do que para o Brasil, o que é real. Por exemplo, o fato de o Brasil "capturar" $90 \%$ do mercado consumidor uruguaio representaria atender ao equivalente a $1,87 \%$ de seu próprio mercado; já, se o Uruguai "capturasse" $90 \%$ do mercado brasileiro, isso significaria incrementar sua economia em 57 vezes. Num exemplo menos dramático, uma empresa argentina que quisesse conquistar $10 \%$ do mercado brasileiro deveria, no mínimo, faturar o equivalente a $45,62 \%$ do mercado argentino.

A Tabela 6.1 mostra também o nível de produção que ocorre em cada país. Note-se que o produto bruto total (igual ao insumo total) dos quatro países foi de US $\$ 1,128.38$ bilhões e, como no caso do valor adicionado, as grandes desigualdades na dimensão dos mercados refletem hiatos nas estruturas econômicas e, portanto, nas escalas de produção dos países em questão.

\subsubsection{A integração espacial dos mercados}

Com base na Tabela 6.1, pode-se estabelecer alguns índices de integração espacial dos mercados: a) do ponto de vista da produção doméstica exportada, pressupondo que as atividades do mercado nacional são proporcionais à produção total, a distribuição dos coeficientes de produção da Tabela 6.2 permite identificar o grau de dependência por exportações para cada país; b) do ponto de vista dos insumos domésticos e insumos importados, assumindo que as atividades do mercado nacional e as importações são proporcionais ao total de insumos utilizados, a Tabela 6.3 fornece o grau de dependência por insumos nacionais e importados para cada país. 

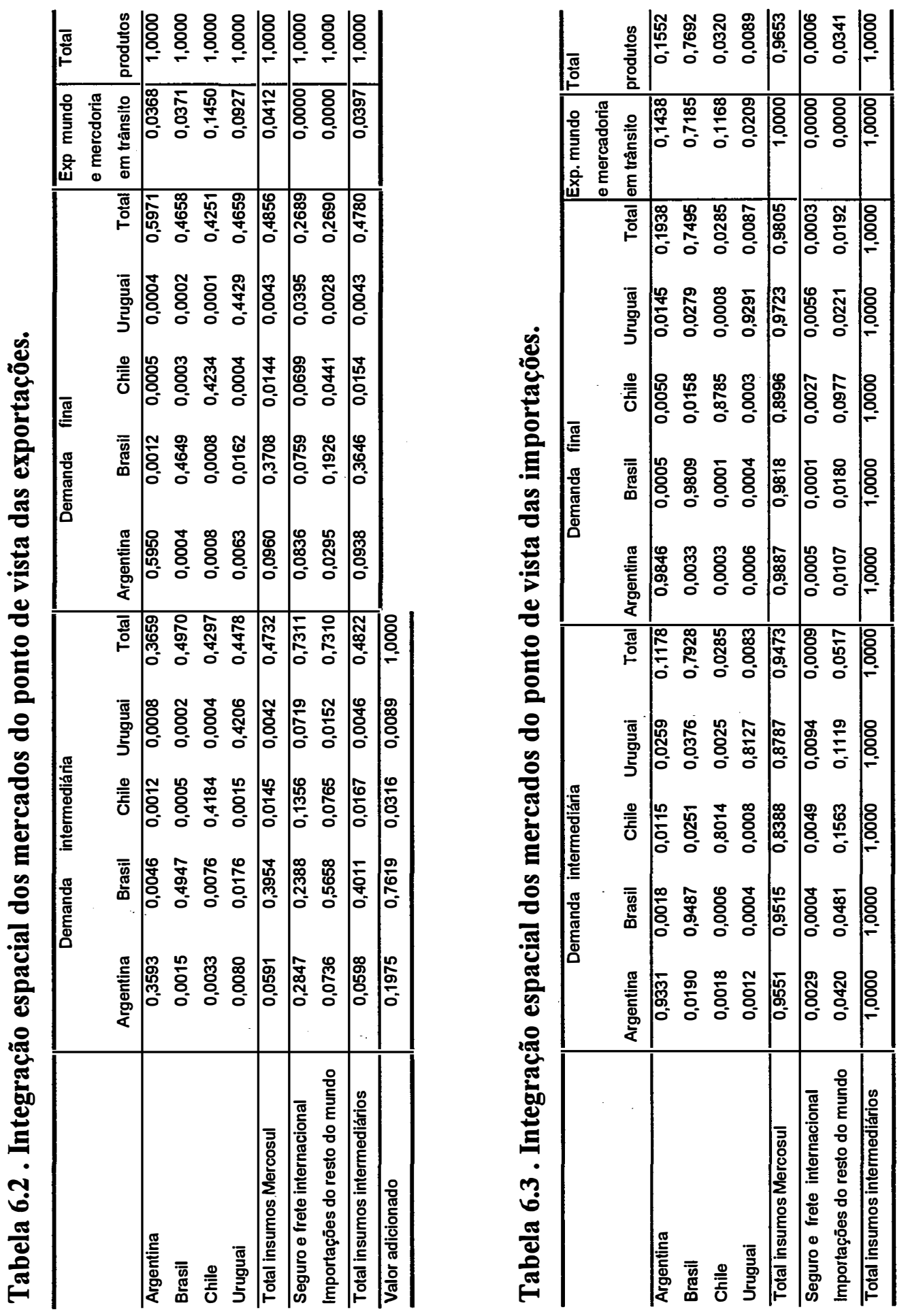
O somatório dos coeficientes de produção de cada país, que corresponde aos blocos das exportações (no lado da demanda intermédiaria, da demanda final e das exportações para o resto do mundo e mercadorias em trânsito) da Tabela 6.2, mostradas na Figura 6.1, indica que o país com uma maior taxa relativa de dependência de exportações é o Chile, com $15,79 \%$ de sua produção doméstica, dos quais $91,83 \%$ são destinados para o resto do mundo (principalmente para os Estados Unidos e a Comunidade Européia) e somente 8,17\%, para os países do Mercosul.

O Uruguai tem a segunda maior proporção de dependência de exportações $(14,50 \%)$ e, como no caso do Chile, ainda que em menor magnitude, do total de suas exportações, $64,92 \%$ vai para o resto do mundo. Porém, cabe mencionar que o Uruguai detém a maior taxa relativa de exportações $(35,08 \%)$ com os países do Mercosul.

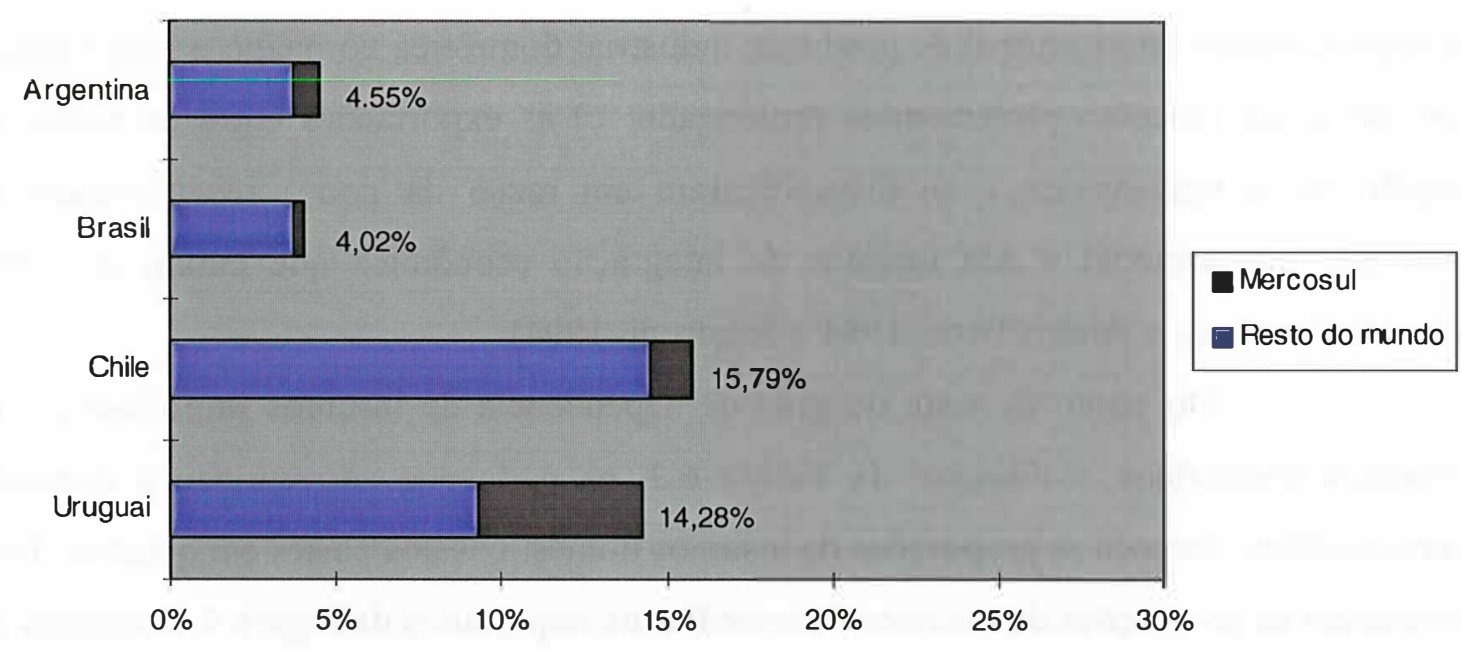

\section{Figura 6.1 - Participação da produção exportada para o resto do mundo e para o Mercosul sobre o produto total.}

As proporções de exportações na produção total do Brasil $(4,02 \%)$ e da Argentina (4,55\%), por sua vez, mostram níveis inferiores com relação às economias do Chile e Uruguai. Contudo, a participação relativa de suas respectivas exportações para o resto do mundo (Brasil, 92,23\% e Argentina, 80,88\% de suas exportações totais) e para 
o Mercosul (Brasil, 7,77\% e Argentina, 19,12\%) apresenta padrões relativos similares aos do Chile.

Em síntese, o quadro geral da distribuição dos coeficientes do produto (Tabela 6.2) evidencia um baixo grau de dependência de exportações. Isso significa que os mercados analisados, do ponto de vista das exportações, apresentam uma integração espacial limitada com o mercado mundial, adquirindo características dramáticas quando relacionadas ao Mercosul.

Essa baixa dependência de exportações dos países da região encontra sua explicação, entre outros, nos seguintes fatores: a) as políticas de substituição de importações do passado, que promoveram o desenvolvimento da estrutura de produção industrial, canalizaram, também, o sentido do comércio para abastecer o consumo doméstico e consolidar a pauta de exportação tradicional de matéria-prima e produção agrícola para o resto do mundo, o que, em última instância, forneceu divisas para a formação do setor industrial (Prebisch, 1950 e Cepal, 1951); b) a falta de competitividade internacional da produção industrial doméstica no médio e longo prazo, devido a um processo protecionista prolongado; c) as exportações entre os países da região só se mantiveram e se diversificaram em razão da pouca receptividade do mercado internacional e dos intentos de integração econômica que datam de 1960, quando foi criada a Alalc (Tussi, 1981 e Sandroni, 1994).

Do ponto de vista do grau de dependência de insumos importados e de insumos domésticos, a diagonal da Tabela 6.3, na parte que corresponde à demanda intermediária, fornece as proporções de insumos domésticos dos países em questão. Isso, associado às proporções de insumos intermediários importados da Figura 6.2 (obtidas do somatório dos blocos de importações da demanda intermediária), permite identificar algumas características gritantes das transações internacionais ligadas à produção doméstica.

O Chile, com uma população pequena, recursos naturais agrícolas limitados, pouca área e, desde a época colonial, caracterizando-se como um típico exportador de minerais, apresenta uma proporção de insumos domésticos de 80,64\%; conseqüentemente, importa uma considerável porção de insumos para a produção 
doméstica (19,36\%), dos quais $80,73 \%$ vêm do resto do mundo e somente $19,27 \%$, dos países do Mercosul.

O Uruguai apresenta a segunda proporção mais baixa de insumos domésticos $(82,22 \%)$ e similar à do Chile; contudo, na estrutura de importações, apesar da predominância do resto do mundo, com $62,94 \%$, os restantes $37,06 \%$ de insumos para a produção doméstica vêm do Mercosul, o que o configura como o país que mais importa das economias da região.

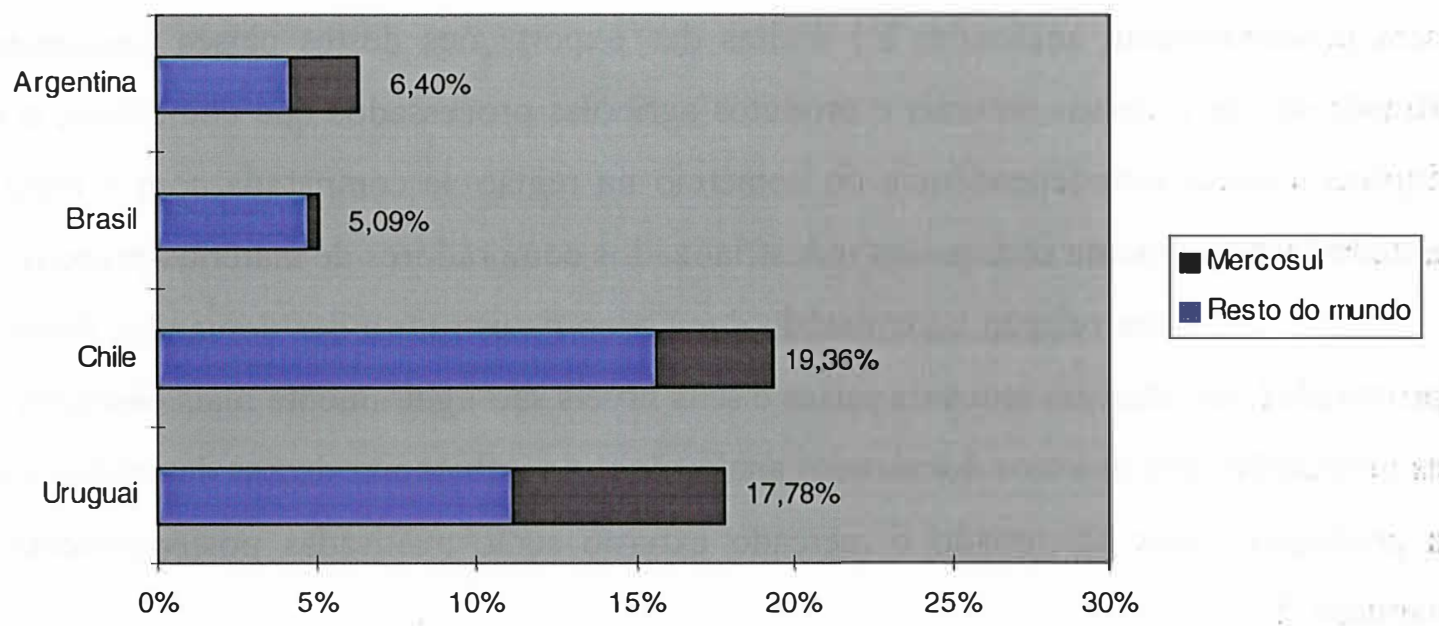

Figura 6.2 - Participação dos insumos importados de uso intermediário provenientes do resto do mundo e do Mercosul sobre o total de insumos.

As proporções de insumos domésticos do Brasil $(94,91 \%)$ e da Argentina $(93,60 \%)$ assinalam uma taxa de dependência com o resto do mundo relativamente mais baixa que a do Chile e Uruguai. No entanto, a estrutura da taxa de dependência da Argentina se mostra similar à do Uruguai e, em menor grau, à do Chile: do total de importações, $65,62 \%$ se originam dos países do resto do mundo e os restantes $34,38 \%$, do Mercosul. Já a estrutura de dependência do Brasil apresenta-se completamente diferente: $94,50 \%$ são importações do resto do mundo, e somente 5,50\%, dos países parceiros. Apesar disso, no contexto do Mercosul, na estrutura de importações da 
Argentina, Chile e Uruguai (Tabela 6.3), em virtude do volume das transações internacionais, os insumos de origem brasileira são os mais predominantes.

Enfim, as importações intermediárias, em geral, reafirmam as ponderações anteriores: os mercados das economias do Mercosul apresentam uma limitada integração espacial inter-regional e mundial. Vários são os fatores que contribuem para isto: a) além da política de substituição de importações do passado e dos níveis elevados de protecionismo, mencionados anteriormente, há uma necessidade relativamente pequena de insumos intermediários importados devido aos baixos níveis de industrialização do Uruguai e do Chile e, em menor dimensão, da Argentina, o que será posteriormente analisado; b;) muitas das exportações destes países (incluindo o Brasil) são de recursos naturais e produtos agrícolas processados que coincidem, o que explica a baixa interdependência do comércio na região se comparada com o resto do mundo (especialmente com países industrializados compradores de matérias-primas).

Com relação ao conteúdo doméstico na estrutura das demandas finais, as proporções são altas em todos os países e seus níveis são ligeiramente mais elevados que as proporções dos insumos domésticos analisados. As influências dessas demandas sobre a produção, valor adicionado e mercado externo serão analisadas posteriormente no capítulo 7.

\subsection{As ligações industriais e os setores-chave}

A análise do processo de interdependência das relações intersetoriais de um conjunto dos países está baseada no fato de que os produtos não servem somente para as indústrias, mas, também, para satisfazer as necessidades dos setores de demanda final. Assim, visto que, no modelo insumo-produto, cada demanda final de um país é exógena, a quantidade que deveria ser produzida em cada país e a força relativa dos efeitos de repercussão nas diferentes indústrias (ligações intersetoriais) podem ser determinadas.

Nesse sentido, diversos métodos procuram mensurar as ligações intersetoriais com o objetivo de identificar setores-chave, na definição de Rasmussem 
(1956) e Hirschman (1958), ou pólos de crescimento, na definição de Perroux (1955) e Myrdal (1957). Esses métodos, que permitem caracterizar as estruturas de transações nacionais e internacionais, estão também associados à idéia de estabelecer prioridades na alocação de recursos e na estratégia de promoções industriais. Isso porque se espera que os recursos alocados em setores-chave, dependendo da política a ser implementada, estimulem um crescimento mais rápido da produção, do emprego e da interdependência econômica do que se fossem alocados em outros setores.

Parece, no entanto, haver pouco acordo entre os métodos com relação à identificação precisa dos setores-chave, uma vez que: a) não levam em consideração variáveis determinantes no desenvolvimento dos países, como, por exemplo, os custos comparativos, a eficiência na produção e no consumo e a disponibilidade de recursos naturais na decisão sobre que tipo de setor deve ser promovido a setor-chave; b) apresentam, segundo Guilhoto et al. (1994), a dificuldade de identificar quais seriam os setores que contribuem acima da média para a economia, tanto dentro de uma perspectiva ex-post como ex-ante e c) segundo Bulmer (1982), não garantem que os estímulos potenciais induzidos pelos encadeamentos em uma economia aberta irão se realizar. Discussões a esse respeito podem ser encontradas em McGilvray (1977), Hewings (1982) e Haddad (1989).

Nesse contexto, os argumentos de Guilhoto et al. (1994), para que se considerem os métodos que mensuram índices de ligações como complementares na análise e não excluentes no sentido de uma técnica como sendo superior às outras, são válidos na medida em que esse tipo de conciliação permite determinar setores-chave num espectro de premissas mais amplo. Nesse sentido, os índices de ligações relevantes que podem ser extraídas das matrizes insumo-produto devem ser considerados como um primeiro passo para o desenho de estratégias setoriais de desenvolvimento dos países.

Com base nesses fatos, esta seção pretende identificar, através de mais de um método, os setores que mais dinamizam a economia do Mercosul. A idéia básica consiste em visualizar, considerando o Mercosul como um só espaço econômico, o nível de relações intersetoriais existentes entre os países, estabelecendo até que ponto a 
integração dos mercados terá um carro-chefe em nível de indútrias, ou seja, quais serão os setores que determinarão o perfil de uma maior interdependência comercial na região.

\subsubsection{Os índices de Rasmussen - Hirschman}

Considerando estritamente a estrutura interna da economia, com base no modelo insumo-produto internacional e seguindo a metodologia de Rasmussen (1956) e Hirschman (1958), pode-se estabelecer os setores que teriam o maior poder de encadeamento dentro da economia, ou seja, os índices de ligações para trás, que estimam o quanto um setor demanda dos outros, e os índices de ligações para frente, que estimam o quanto este setor é demandado pelos outros. Desse modo, define-se $b_{i j}$ como sendo um elemento da matriz inversa internacional de Leontief $B ; B^{*}$ como sendo a média de todos os elementos de $B$ e $B_{*_{j}} ; B_{i^{*}}$ como sendo, respectivamente, a soma de uma coluna e de uma linha típica de $B$. Têm-se, então, os índices.

Índices de ligações para trás (poder de dispersão):

$$
U_{j}=\left[B_{*_{j}} / n\right] / B^{*}
$$

Índices de ligações para frente (sensibilidade da dispersão):

$$
U_{i}=\left[B_{i *} / n\right] / B^{*}
$$

Rasmussen e Hirschman estabeleceram que índices para frente ou para trás maiores do que 1 indicam setores acima da média, portanto, setores-chave para 0 crescimento da economia. Os índices de ligações para frente e para trás do Mercosul são mostrados na Tabela 6.4 . 


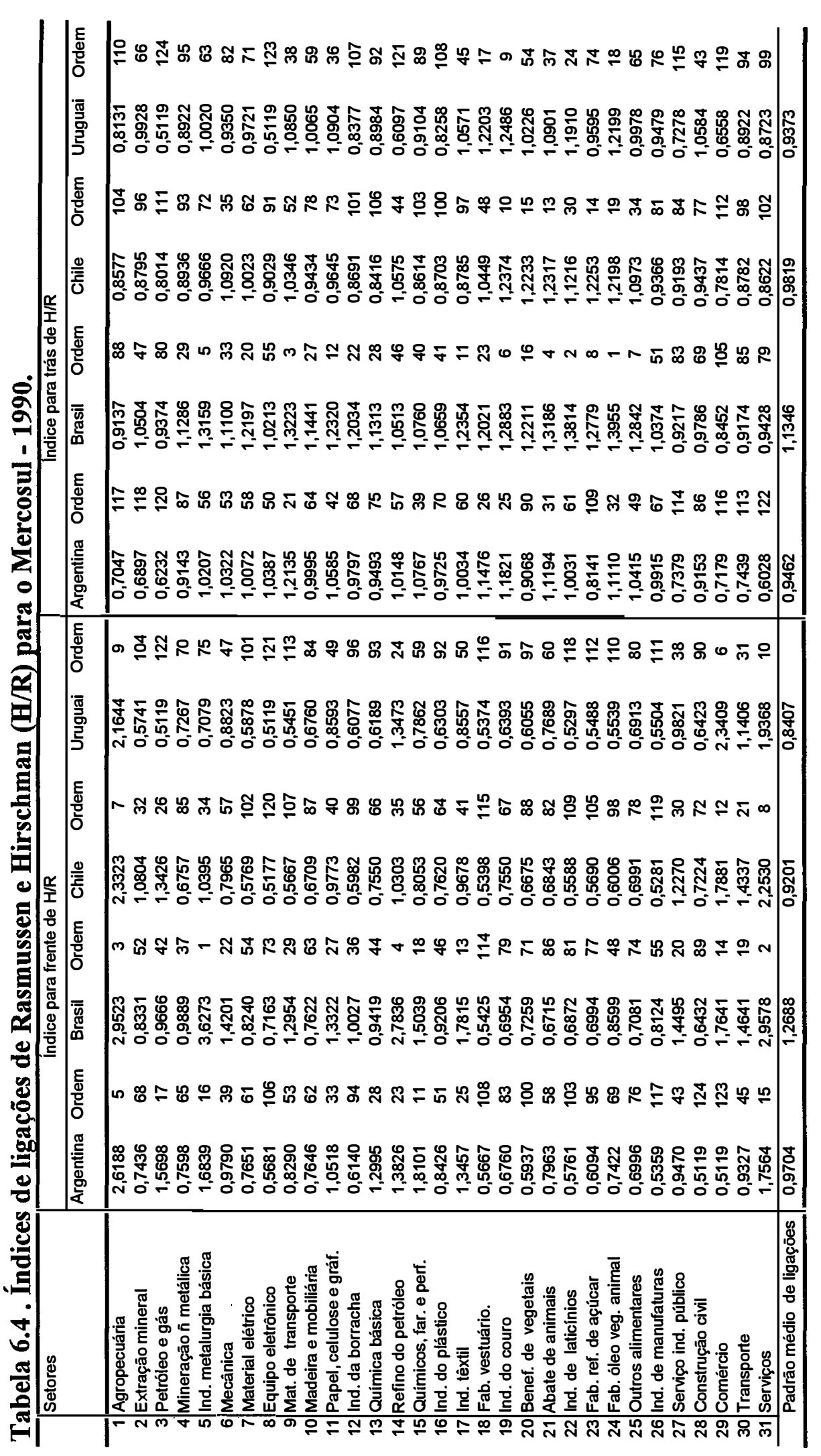


Entretanto, antes de discutir as informações da Tabela 6.4, é importante uma breve descrição de sua organização. Note-se que existe um total de 124 índices para frente e de 124 índices para trás, o que indica que o tamanho da matriz inversa do Mercosul é da ordem de (124x124) setores, ou seja, 31 setores para cada país. Assim, esperar-se-ia que, na coluna que contém o nome dos setores, normalmente, fossem listados 124 setores; contudo, lembrando que em cada país os setores correspondentes às linhas e colunas são comuns, faz sentido simplesmente listar 31 setores, até porque este tipo de organização dos dados permite que se visualizem as diferenças de comportamento dos países "dentro" de Mercosul. Note-se, ainda, que, de acordo com o tamanho que apresentam os índices, foi-lhe associada uma ordem de importância que vai da maior à menor.

Feitas essas considerações, a partir da Tabela 6.4, é possível resumir e padronizar os índices para frente e os índices para trás de cada país (Figura 6.3), os quais incluem o grau de ligações internacionais de cada país.

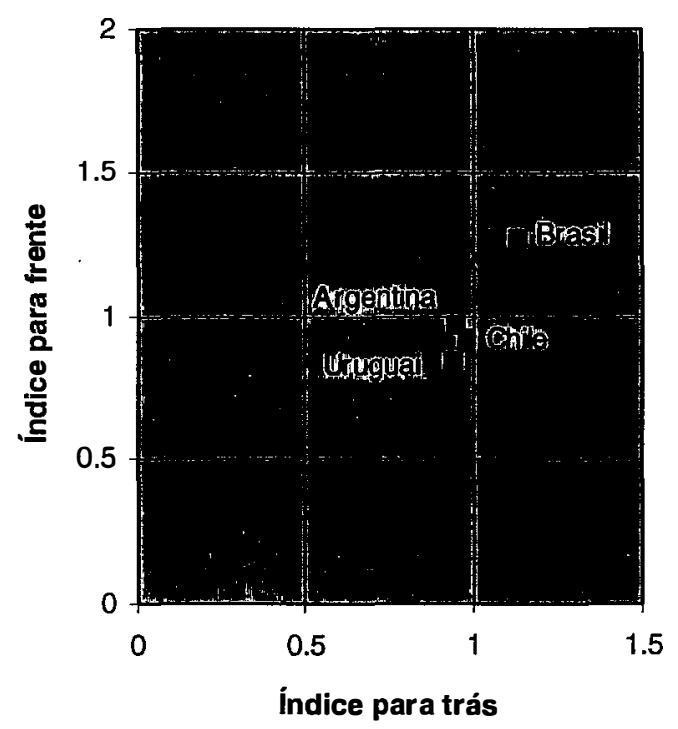

Figura 6.3 - Síntese dos padrões médios de comportamento dos índices de Rasmussem e Hirschman para os países do Mercosul. 
Na Figura 6.3, dois padrões distintos emergem "dentro"do Mercosul: a) um país com uma estrutura industrial melhor articulada (Brasil) e b) aqueles países (Argentina, Chile e Uruguai) que estariam tentando ainda implementar e consolidar sua indústria.

O Brasil apresenta maiores índices de ligações para frente e para trás em relação à média das indústrias do Mercosul, o que indica que as negociações de sua economia estão melhor articuladas com o mercado doméstico e internacional. Contudo, considerando os níveis de integração espacial encontrados nas Tabelas 6.2 e 6.3, isso não significa ligações internacionais mais fortes com seus países parceiros ou com o resto do mundo; na verdade, é o resultado de ligações fortes entre as indústrias brasileiras.

Contrariamente, a Argentina, o Chile e o Uruguai exibem os padrões típicos de ligações fracas entre as indústrias domésticas, refletidos pelos baixos índices, ou seja, os índices médios para frente oscilam entre 0,8407 e 0,9704 e os índices médios para trás, entre 0,9373 e 0,9819 (Tabela 6.4).

No contexto de uma definição estrita de setor-chave (Mcgilvray, 1977), como aquele que apresenta, simultaneamente, índices de ligações para frente e para trás maiores que 1, os resultados da Figura 6.3, associados a uma análise mais detalhada dos padrões de ligações interindustriais e de como elas variam entre os países (Tabela 6.4), sugerem algumas diretrizes básicas para o desenho de políticas de promoção industrial de cada país.

Para o Brasil, por exemplo, os resultados sugerem que seria mais conveniente implementar políticas de desenvolvimento através de setores-chave com altos poderes de ligações para frente do que naqueles com altos níveis de ligações para trás, pois o nível de suas ligações para frente $(1,2688)$ se mostra ligeiramente superior aos índices de ligações para trás $(1,1346)$. Desse modo, dos oito setores-chave identificados (setores 5, 6, 9, 11, 12, 14, 15 e 17), o desenvolvimento econômico baseado em setores com ligações fortes para frente, tais como da metalurgia básica (setor 5), mecânica (setor 6), papel (11), têxtil (setor 17) e, portanto, de exportação, é altamente desejável. 
Objetivando caracterizar de forma mais clara o perfil das estruturas, de transações internacionais, o "relaxamento" do conceito restrito de setores-chave permite a construção de uma amostra maior de indústrias que se coloquem nesta classificação. Assim, seguindo os critérios de Rasmussem (1956) e Hirschman (1958), índices maiores do que 1 constituem setores-chave para o crescimento da economia.

Nessa perspectiva menos restrita, o Brasil apresenta 37 setores-chave (13 com ligações para frente e 24 com ligações para trás), que evidenciam as seguintes características de sua economia: a:) o fato de os índices de ligações para trás serem elevados na maior parte das indústrias manufatureiras - como, por exemplo, nos setores de material elétrico, equipamento eletrônico, material de transporte, entre outros - e, simultaneamente, o fato de os índices de ligações para frente serem ainda mais elevados em setores, tais como metalurgia básica, agropecuária, serviços, etc., permitem afirmar que o Brasil possui uma indústria diversificada que está centrada ao redor das indústrias de produção de matéria-prima e manufatureiras; b:) em virtude de, na estrutura de setores-chave, o número de setores com ligações para trás quase que duplicar o número dos setores com ligações para frente, fica evidente que as políticas dirigidas a estimular a demanda por insumos intermediários também são plausíveis, sobretudo se essa demanda for atendida por insumos domésticos e, no contexto internacional, por insumos da região (no capítulo 7, quando é analisado o comércio inter-regional induzido pela demanda final, esse processo fica mais evidente); c) o Brasil, em razão de sua melhor articulação industrial em relação aos outros países, certamente, apresenta uma maior capacidade para induzir "dentro" do Mercosul uma maior integração espacial dos mercados.

Foi mencionado anteriormente que a Argentina, o Chile e o Uruguai se enquadram no padrão de ligações industriais fracas. A isso se deve acrescentar que uma análise mais detalhada, com base na Tabela 6.4, mostra que existem claras diferenças neste grupo de economias.

No caso da Argentina, a Figura 6.3 evidencia que as ligações médias para frente $(0,9704)$ de sua indústria são ligeiramente predominantes sobre as ligações médias para trás $(0,9462)$ e, sob a definição estrita de setores-chave, a partir da Tabela 6.4, apresentam-se cinco setores (setores 5, 11, 14, 15 e 17). Portanto, se este país desejar e 
adotar, por exemplo, políticas de crescimento industrial, os dados sugerem que seria realista utilizar setores-chave com altos poderes de ligações para frente, tais como a indústria metalúrgica básica, refino de petróleo e derivados, fabricação de químicos e indústria têxtil e promoção de exportações.

Ao se considerar, porém, setores-chave aqueles que apresentam apenas um índice maior do que 1, emergem 25 deles. Este fato e a estrutura de setores-chave (9 setores com ligações para frente e 15 setores com ligações para trás), em que predominam as indústrias manufatureiras, permitem afirmar que se trata de uma economia diversificada e assemelhada à do Brasil, já que também apresenta índices de ligações para frente elevados nas indústrias que produzem matéria-prima; porém, isso tudo dentro de um padrão médio industrial de ligações fracas (Figura 6.3).

A indústria orientada para a exportação (Tabela 6.2), tanto do Chile como do Unuguai, tem induzido à utilização de produtos intermediários predominantemente domésticos; em conseqüência, na Tabela 6.4 e Figura 6.3, as ligações médias para trás (para o Chile, 0,9819 e para o Uruguai, 0,9373) apresentam-se maiores que as ligações médias para frente (para o Chile, 0,9201 e para o Uruguai, 0,8407). No entanto, na definição estrita de setor-chave, só foi identificado um setor-chave para o Chile (setor 4) e nenhum para o Uruguai. Apesar disso, os índices de ligações sugerem que, para a implementação de políticas de desenvolvimento industrial, setores com ligações para trás devem ser priorizados nessas economias.

Com o "relaxamento" do conceito restrito de setores-chave, o número de setores-chave com ligações para frente do Chile (9 setores) coincide com o da Argentina, existindo, porém, claras diferenças: o Chile apresenta como setores com poder de ligações para frente as atividades de extração mineral, serviços industriais, comércio e transporte; já a Argentina mostra-se diferente porque destaca os setores de papel, química básica, indústria farmacêutica e perfumaria e a indústria têxtil. Nessa linha de análise, o Uruguai apresenta um padrão distanciado do da Argentina e próximo ao do Chile, já que seus cinco setores-chave com ligações para frente assemelham-se aos nove setores que apresenta este último. 
Quando analisado o número de setores-chave com índices para trás entre os três países, verifica-se que a Argentina detém quinze deles; o Chile e o Uruguai, doze cada um. Duas características básicas podem ser resgatadas: a) os índices de ligações médios do Chile são ligeiramente superiores aos da Argentina e do Uruguai; b) na maioria das vezes, o tipo de setores-chave para os países coincide. Portanto, a importância relativa das ligações para trás se mostra bastante parecida, o que não significa uma estrutura de demanda de insumos intermediários similar no "interior" de cada indústria.

Em síntese, pode-se afirmar que os baixos índices de ligações para frente de algumas indústrias pesadas, tais como a metalurgia básica, mecânica, material elétrico, material eletrônico e material de transporte, apresentados pelos três países, com maior ênfase pelo Chile e Uruguai, indicam que as bases para a implementação de um processo amplo de industrialização de suas economias não são consistentes. Certamente, esta particularidade explica o padrão de fracas relações interindustriais, tão evidentes na Figura 6.3.

Por outro lado, e ainda com base na Tabela 6.4, pode-se estabelecer, de acordo com o tamanho dos índices de ligações, os setores com maior capacidade para dinamizar a economia do Mercosul. Considerando os quinze maiores índices de ligações para frente, observa-se que a oferta de insumos se processa através dos setores $5,31,1$, 14, 1729 do Brasil; dos setores 1, 15 e 31 da Argentina; dos setores 1, 29, e 31 do Chile e dos setores 1, 29, e 31 do Uruguai. Com essas informações, duas características podem ser salientadaș: a) as relações intersetoriais para frente estão dinamizadas principalmente através dos setores agropecuários e de serviços de todos os países; b) dos quinze setores, seis são da economia brasileira e, dentre eles, quatro fazem parte dos quatro maiores indices para frente do Mercosul.

Por sua vez, considerando no Mercosul os quinze maiores índices para trás, dez deles são da economia do Brasil ( setores 5, 9, 11, 17, 19, 21, 22, 23, 24 e 25), quatro fazem parte da economia chilena (setores 19, 20, 21 e 23) e somente um pertence ao Uruguai (setor 19). A demanda de insumos para o processamento industrial 
concentra-se, então, em sua maior parte na economia brasileira. Note-se ainda, nesta categorização, que a Argentina não apresenta setores.

Deve-se considerar, contudo, que as informações, tanto dos quinze maiores índices para frente como dos índices para trás, não mostram se a importância das ligações intersetoriais derivam preponderantemente do comércio entre países ou do comércio entre as indústrias de cada país, ou seja, não mostram os elos que processam as ligações intersetoriais mais relevantes na economia.

\subsubsection{0 campo de influência}

Um dos problemas dos índices de ligações é que, apesar de estes avaliarem a importância do setor em termos dos seus impactos no sistema como um todo, torna-se difícil visualizar os principais elos de ligações dentro da economia, ou seja, quais seriam os coeficientes que, se alterados, teriam um maior impacto no sistema como um todo. Para suprir essa deficiência do índice de ligação de RasmussenHirschman, utilizou-se o conceito de campo de influência desenvolvido por Sonis e Hewings (1989). Cabe, porém, mencionar, que a noção deste conceito não está dissociada dos índices de ligações de Rasmussen-Hirschman, já que, também para seu cálculo, somente se considera a estrutura interna da economia.

$\mathrm{O}$ conceito de campo de influência descreve como se distribuem as mudanças dos coeficientes diretos no sistema econômico como um todo, permitindo, dessa forma, que se determinem quais as relações entre os setores que seriam mais importantes dentro do processo produtivo. O procedimento para o cálculo do campo de influência do Mercosul requer a matriz de coeficientes diretos $A=\left|a_{i j}\right|$, sendo preciso definir a matriz de variações incrementais nos coeficientes diretos de insumo $E=\left|\varepsilon_{i j}\right|$. As correspondentes matrizes inversas internacionais de Leontief são dadas por $B=[I-A]^{-1}=\left|b_{i j}\right|$ e por $B(\varepsilon)=[I-A-\varepsilon]^{-1}=\left|b_{i j}(\varepsilon)\right|$. Segundo Sonis \& Hewings $(1989 \mathrm{e}$ 1994), caso a variação seja pequena e só ocorra num coeficiente direto, isto é, 


$$
\varepsilon_{i j}=\left\{\begin{array}{cc}
\varepsilon & i=i_{1}, j=j_{1} \\
0 & i \neq i_{1}, o u, j \neq j_{1}
\end{array}\right.
$$

tem-se que o campo de influência dessa variação pode ser aproximado pela expressão,

$$
F\left(\varepsilon_{i j}\right)=\frac{\left[B\left(\varepsilon_{i j}\right)-B\right]}{\varepsilon_{i j}}
$$

onde $F\left(\varepsilon_{i j}\right)$ é uma matriz (nxn) do campo de influência do coeficiente $a_{i j}$. -

Para se determinar quais seriam os coeficientes que possuem o maior campo de influência, é necessário associar-se a cada matriz $F\left(\varepsilon_{i j}\right)$ um valor, o qual é dado por

$$
S_{i j}=\sum_{k=1}^{n} \sum_{l=1}^{n}\left[f_{k l}\left(\varepsilon_{i j}\right)\right]^{2}
$$

onde $S_{i j}$ é o valor associado à matriz $F\left(\varepsilon_{i j}\right)$; portanto, os coeficientes diretos que possuírem os maiores valores de $S_{i j}$ serão aqueles com o maior campo de influência dentro da economia como um todo. Na Figura 6.4, apresentam-se os resultados desses cálculos.

A questão a saber é: quais dos setores-chave identificados causam maiores mudanças inter-regionais na economia do Mercosul ao imprimirem pequenas mudanças nos coeficientes de produção?

Os 124 coeficientes setoriais com maior campo de influência selecionados indicam uma característica marcante no sistema econômico: em geral, os principais elos de ligações da economia do Mercosul são dominados, em sua maior parte, por setores vinculados à economia brasileira. Certamente, a melhor articulação das indústrias do Brasil, a elevada escala de produção e, fundamentalmente, a complementaridade dos fluxos de comércio com as cadeias produtivas dos países parceiros explicam esse fato. 
Nesse sentido, dentre os setores-chave identificados anteriormente, as relações de comercialização que envolvem principalmente os setores da indústria metalúrgica básica (setor 36), indústria têxtil (setor 48) e agropecuária (setor 32) do Brasil podem gerar grandes impactos sobre o restante das economias, os quais podem ser distinguidos de acordo com o sentido do comércio.

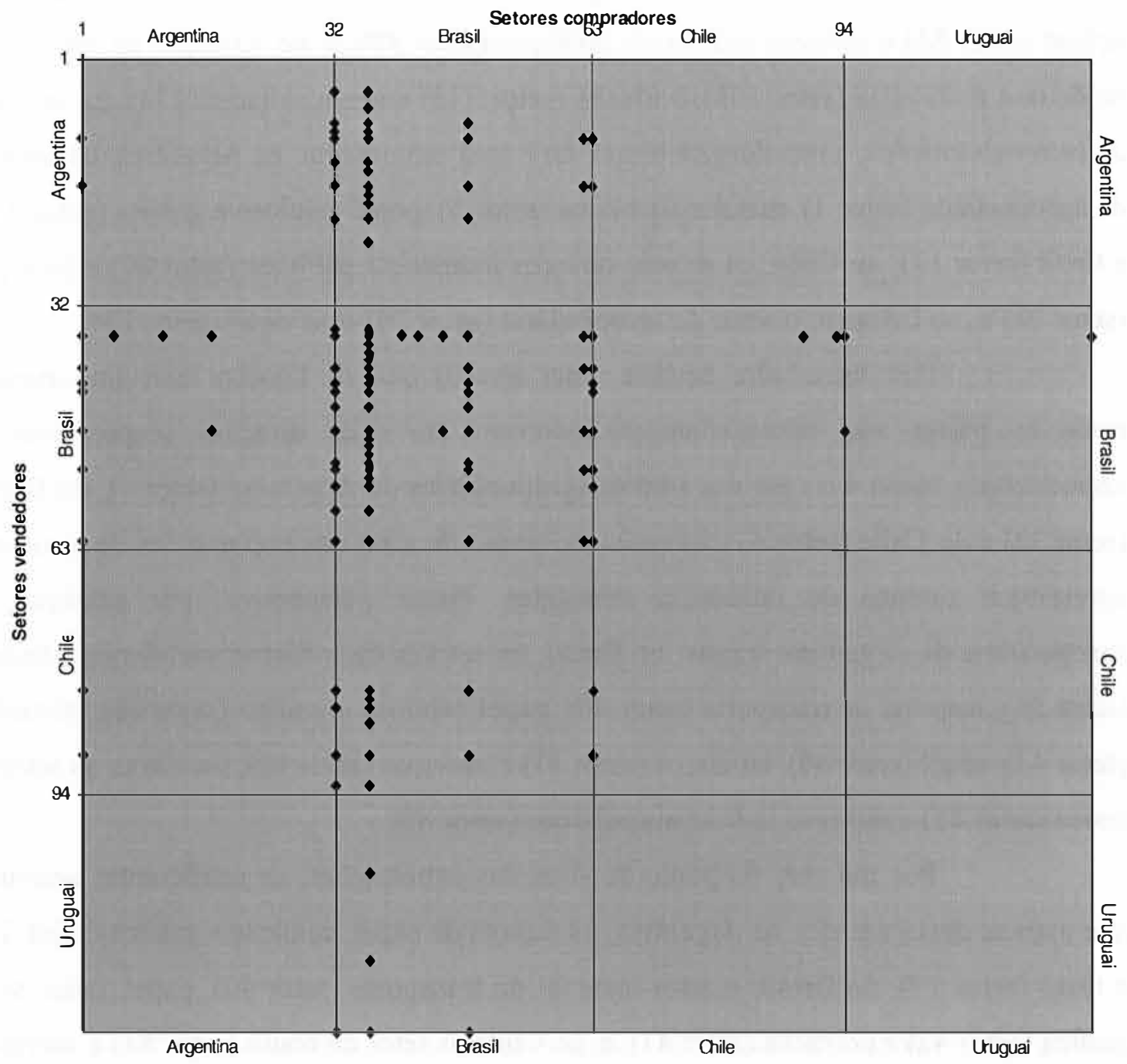

Figura 6.4 . Coeficientes setoriais com maior campo de influência no Mercosul. 
Por exemplo, a metalurgia básica brasileira movimenta, através de suas importações, principalmente: na Argentina, os setores da metalurgia básica (setor 5), material elétrico (setor 7), material de transporte (setor 9), madeira e mobiliária (setor 10), papel celulose e gráfica (setor 11), refino do petróleo (setor 14), farmácia e perfumaria (setor 15), têxtil (setor 17), vestuário (setor 18), couro (setor 19), abate de animais (setor 21) e óleo vegetal e animal (setor 24); no Chile, os setores da indústria do couro (setor 81), beneficiamento de vegetais (setor 82), serviços (setor 93), refino de açúcar (setor 85) e serviços industriais públicos (setor 89); e, no Uruguai: os setores da madeira e mobiliária (setor 103), borracha (setor 115) e serviços (setor 124). Já, através de suas exportações, a metalurgica básica do Brasil movimenta: na Argentina, os setores da agropecuária (setor 1), metalurgia básica (setor 5), papel celulose e gráfica (setor 11), e têxtil (setor 17); no Chile, os setores serviços industriais públicos (setor 89) e serviços (setor 93) e, no Uruguai, o setor da agropecuária (setor 94) e serviços (setor 124).

Por outro lado, deve-se notar que os elos de ligação mais importantes entre os países não necessariamente ocorrem em duas direções (exportações e importações), como é o caso dos setores agropecuários da Argentina (setor 1), do Brasil (setor 32) e do Chile (setor 63), os quais, do ponto de vista das importações de insumos, apresentam campos de influência relevantes. Nessa perspectiva, por exemplo, a agropecuária da Argentina aciona: no Brasil, os setores da indústria metalúrgica básica (setor 36), material de transporte (setor 40), papel celulose e gráfica (setor 42), borracha (setor 43), têxtil (setor 48), laticínios (setor 53) e serviços (setor 62); no Chile, os setores couro (setor 81) e serviços industriais públicos (setor 89).

Por sua vez, do ponto de vista das exportações, os coeficientes setoriais que mais se destacam são: na Argentina, os setores de papel, celulose e gráfica (setor 11) e têxtil (setor 17); no Brasil, o setor material de transporte (setor 40), papel, celulose e gráfica (setor 42) e borracha (setor 43), e, no Chile, o setor de couro (setor 81) e serviços industriais públicos (setor 89).

Em suma, os coeficientes com maior campo de influência no Mercosul sugerem que existem grandes possibilidades de intensificar a interdependência industrial, através da promoção de importações ou exportações, nos setores da 
metalurgia básica e têxtil do Brasil e setores agropecuários da Argentina, Brasil e Chile. Porém, ficou evidente que esse processo, em suas diretrizes básicas, necessariamente, terá que ser liderado pelo Brasil, até porque, nos coeficientes setoriais de maior abrangência, está implícita a idéia de uma participação ativa das indústrias brasileiras nas cadeias-chave dos países do Mercosul tanto quando importa como quando exporta.

\subsubsection{Os índices puros de ligações}

Baseado nas críticas de Cella (1984), de que os índices de RasmussenHirschman não levam em consideração os diferentes níveis de produção em cada setor da economia, o índice puro de ligações intersetoriais para frente, para trás e total desenvolvido por Guilhoto et al. (1996) visa medir a importância de um dado setor para a economia em termos de valor da produção gerado por este. Este índice corrige um erro de decomposição de Cella (1984) e Clements (1990) e aprimora uma versão inicial do índice puro de ligações apresentado por Guilhoto et al. (1994).

Procedendo à decomposição da matriz de coeficientes técnicos, tem-se que

$$
A=\left(\begin{array}{cc}
A_{j j} & A_{j r} \\
A_{r j} & A_{r r}
\end{array}\right)=\left(\begin{array}{cc}
A_{j j} & A_{j r} \\
A_{r j} & 0
\end{array}\right)+\left(\begin{array}{cc}
0 & 0 \\
0 & A_{r r}
\end{array}\right)=A_{j}+A_{r}
$$

onde a matriz $A_{j}$ representa o setor $j$ isolado do resto da economia e a matriz $A_{r}$ representa o resto da economia.

Da equação (6.6), pode-se chegar a

$$
B=(I-A)^{-1}=\left(\begin{array}{cc}
B_{i j} & B_{j r} \\
B_{r j} & B_{r r}
\end{array}\right)=\left(\begin{array}{cc}
\Delta_{i j} & 0 \\
0 & \Delta_{r r}
\end{array}\right)\left(\begin{array}{cc}
\Delta_{j} & 0 \\
0 & \Delta_{r}
\end{array}\right)\left(\begin{array}{cc}
I & A_{j r} \Delta_{r} \\
A_{r j} \Delta_{j} & I
\end{array}\right)
$$


onde os elementos da equação (6.7) são definidos como:

$$
\begin{aligned}
& \Delta_{j}=\left(I-A_{j j}\right)^{-1} \\
& \Delta_{r}=\left(I-A_{r r}\right)^{-1} \\
& \Delta_{j j}=\left(I-\Delta_{j} A_{j r} \Delta_{r} A_{r j}\right)^{-1} \\
& \Delta_{r r}=\left(I-\Delta_{r} A_{r j} \Delta_{j} A_{j r}\right)^{-1}
\end{aligned}
$$

Desse modo, a partir da equação (6.7), é possível verificar como ocorre o processo de produção na economia e também derivar um conjunto de multiplicadores e/ou ligações.

Com as informações contidas na equação (6.7) e usando $X=(I-A)^{-1} F$, pode-se derivar um conjunto de índices que permitem: a) ordenar as regiões em termos de sua importância no valor da produção que gera; b) verificar como ocorre o processo de produção na economia. Esses índices podem ser obtidos por

$$
\left(\begin{array}{c}
X_{j} \\
X_{r}
\end{array}\right)=\left(\begin{array}{cc}
\Delta_{j j} & 0 \\
0 & \Delta_{r r}
\end{array}\right)\left(\begin{array}{cc}
\Delta_{j} & 0 \\
0 & \Delta_{r}
\end{array}\right)\left(\begin{array}{cc}
I & A_{j r} \Delta_{r} \\
A_{r j} \Delta_{j} & I
\end{array}\right)\left(\begin{array}{c}
F_{j} \\
F_{r}
\end{array}\right)
$$

Através da multiplicação dos três últimos termos da expressão (6.8), chega-se a

$$
\left(\begin{array}{c}
X_{j} \\
X_{r}
\end{array}\right)=\left(\begin{array}{cc}
\Delta_{j j} & 0 \\
0 & \Delta_{r}
\end{array}\right)\left(\begin{array}{c}
\Delta_{j} F_{j}+\Delta_{j} A_{j r} \Delta_{r} F_{r} \\
\Delta_{r} A_{j j} \Delta_{j} F_{j}+\Delta_{r} F_{r}
\end{array}\right)
$$

onde $A_{j r} \Delta_{r} F_{r}$ é o impacto direto da demanda final do resto da economia sobre a região $j$, isto é, fornece o nível de importações da região $j$ necessário para 
satisfazer o nível de produção do resto da economia dada uma demanda final $\left(F_{r}\right)$; por sua vez, $A_{r j} \Delta_{j} F_{j}$ é o impacto direto da demanda final da região $j$ sobre o resto da economia, ou seja, indica o nível de importações do resto da economia que é necessário para satisfazer a necessidade de produção da região para uma determinada demanda final $\left(F_{\nu}\right)$. Portanto, a nova definição do índice puro de ligações para trás $(P B L)$ será

$$
P B L=\Delta_{r} A_{r j} \Delta_{j} F_{j}
$$

O PBL representa o impacto puro do valor da produção total do setor $j$ na economia dissociada: a) da demanda de insumos que o setor $j$ realiza do próprio setor $j$ e b) dos retornos da economia para o setor $j$ e vice-versa.

Por sua vez, a nova definição do índice puro de ligações para frente $(P F L)$ é dada por

$$
P F L=\Delta_{j} A_{j r} \Delta_{r} F_{r}
$$

O PFL indica o impacto puro da produção total no restante da economia no setor $j$.

Para saber qual é o índice puro do total das ligações (PTL) de cada setor na economia, é possível adicionar o $P B L$ ao $P F L$, visto que estes índices, como se definiu anteriormente, são expressos em valores correntes. Portanto,

$$
P T L=P B L+P F L
$$

Os resultados de tais cálculos se encontram expressos nas Figuras $6.5 \mathrm{e}$ 6.6. Observa-se, com base no valor da produção gerada pelas economias setoriais e nacionais, que a importância dos países para a economia do Mercosul é extremamente diferenciada. 

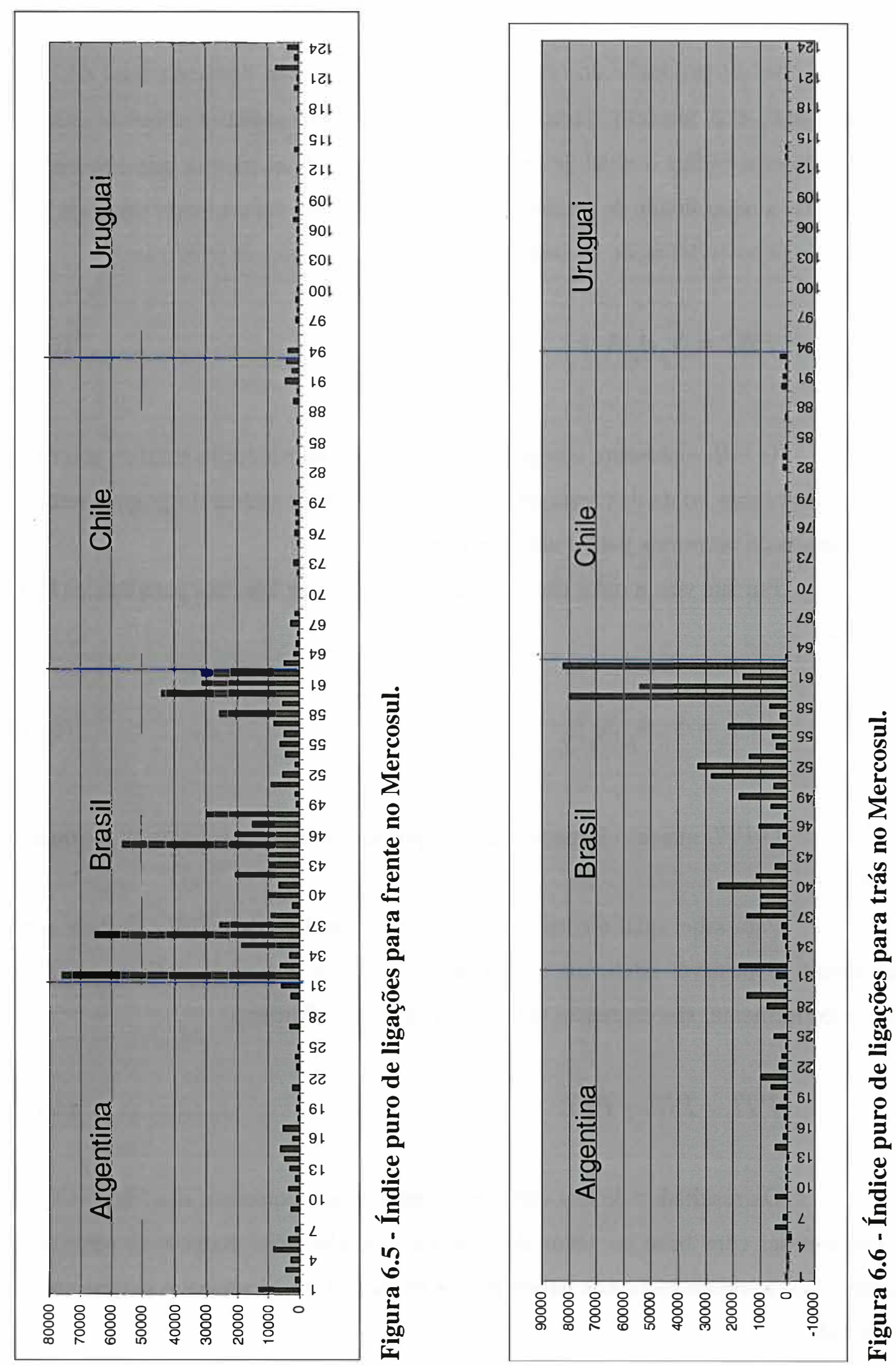
Em nível setorial, os setores que mais destacam o índice puro de ligações para frente, obviamente, estão vinculados à economia brasileira, sendo, em ordem de importância: agropecuária (setor 32), metalurgia básica (setor 36), refino de petróleo (setor 45), comércio (setor 60), transporte (setor 61), serviços (setor 62), têxtil (setor 48) e serviços industriais públicos (setor 58). Frente à dimensão continental da economia brasileira, a participação relativa da Argentina, Chile e Uruguai pode, assim, ser considerada marginal.

O valor da produção para frente gerado dos países parceiros não é, contudo, desprezível. Assim, podem ser destacados os seguintes setores: na Argentina: agropecuário (setor 1), metalurgia básica (setor 5), farmácia e perfumaria (setor 15), têxtil (setor 17) e serviços (setor 31); no Chile: agropecuário (setor 63), comércio (setor 91) e serviços (setor 93) e, no Uruguai: os setores comércio (setor 122), serviços (setor 124) e agropecuário (setor 94 ).

Com relação aos índices puros de ligações para trás, novamente os setores da economia brasileira são os mais relevantes, dos quais se destacam: serviços (setor 62), construção civil (setor 59), comércio (setor 60), abate de animais (setor 52), beneficiamento de vegetais (setor 51) e material de transporte (setor 40). Note-se, porém, que, na maioria dos casos, os índices puros para frente e para trás, os índices de Rasmussem-Hirschman e o campo de influência coincidem ao identificar os setores da indústria metalúrgica, têxtil $\mathrm{e}$, especialmente, o da agropecuária como os mais relevantes, ainda que com uma ordem de importância diferente. Portanto, do ponto de vista das estruturas de produção e do valor da produção gerada, esses setores devem ser considerados para uma mais rápida e maior interdependência inter-regional.

Em síntese, de acordo com o valor da produção que geram os países, os índices puros destacam a importância relativa do Brasil sobre as economias da Argentina, Chile e Uruguai. Esse fato, combinado com os padrões de ligações fortes expressos pelos índices de Rasmussem-Hirschman e os coeficientes setoriais com maior campo de influência que mostra a economia brasileira no Mercosul, reafirma que o perfil de uma maior interdependência ou integração econômica na região será determinado e/ou induzido pelo mercado brasileiro. 
Contudo, essas ligações intersetoriais, que salientam a importância da economia do Brasil, especialmente as assinaladas pelo índice puro, não necessariamente implicam que, na distribuição dos prováveis custos e benefícios derivados do comercio inter-regional, os beneficios se concentrem na economia brasileira, até porque este tipo de interpretação dos resultados levaria a incorrer em um erro "contra-intuitivo", por não se estar distinguindo os resultados absolutos dos relativos. $\mathrm{Na}$ verdade, as relações intersetoriais de alcance inter-regional identificadas no Brasil através dos coeficientes do campo de influência resgatam, nitidamente, a predominância de elos de ligações para trás (importações brasileiras), e esses, por sua vez, associados às maiores potencialidades de ampliação da demanda para a Argentina, Chile e Uruguai que a dimensão econômica dos mercados mostrou (Tabela 6.1), sugerem, pelo contrário, que os benefícios poderão ser maiores nestes países do que no Brasil ou, no mínimo, os mercados serão potencialmente complementares.

Resta saber, portanto, se o Mercosul poderá, efetivamente, vir a representar para o Brasil uma opção de ampliação do espaço de produção e de circulação de mercadorias, e qual é o tipo de complementaridade vigente e potencial entre os setores-chave dos países parceiros em nível de produto, de valor agregado e de comércio inter-regional. 


\section{A INFLUÊNCIA DAS DEMANDAS FINAIS SOBRE A PRODUÇÃO, O VALOR ADICIONADO E O COMÉRCIO EXTERNO NO MERCOSUL EM 1990}

As análises apresentadas nas seções do capítulo anterior mostraram que a dimensão econômica dos países é extremamente desigual; que, na Argentina e no Brasil, os níveis relativos de integração espacial com o mercado internacional e da região são bem mais limitados que os do Chile e Uruguai e que as ligações industriais evidenciam dois padrões bem diferenciados: ligações industriais fortes no Brasil e fracas na Argentina, Chile e Uruguai. Destacam, também, com base nos campos de influência setoriais e índices puros, que, no processo de integração econômica do Mercosul, existem setores-chave com efeitos de alcance inter-regional ligados a setores-chave nacionais, os quais mostram possibilidades concretas de ser intensificada a interdependência setorial através da economia brasileira.

Nesse contexto, este capítulo tem por objetivo caracterizar os níveis de complementariedade econômica vigentes e potenciais dos países do Mercosul e, em decorrência, a possível tendência do comércio na região. Para tanto, em nível agregado e setorial, procura-se, através das demandas finais, identificar e avaliar a importância relativa do comércio internacional, que é relevante na produção induzida, no valor adicionado induzido e no comércio externo induzido de cada país. A idéia básica é aprofundar o conhecimento sobre as estruturas de transações internacionais do Mercosul e caracterizar, na medida do possível, os ajustes interindustriais mais prováveis derivados do processo de integração econômica regional. 


\subsection{Demanda final e produção}

De acordo com a estrutura de transações da matriz insumo-produto internacional do Mercosul, quando a demanda de um país varia, a produção se modifica mais que proporcionalmente pelo fato de seus multiplicadores setoriais, que incluem as transações domésticas e internacionais, excederem a unidade. Nesse sentido, mensurar esse processo, que implica efeitos diretos e indiretos nas cadeias produtivas, é da maior relevância porquanto permite visualizar e qualificar as vantagens de uma maior ou menor interdependência setorial em nível nacional e/ou internacional.

\subsubsection{Produção agregada induzida pelas demandas finais e pelas exportações para o resto do mundo de cada país}

Para examinar a influência do comércio internacional e nacional sobre a produção, é necessário estimar a produção induzida causada pela demanda final e exportações para o resto do mundo de cada país, que é definida da seguinte maneira:

$$
X^{*}=(I-A)^{-1} F
$$

onde:

$X^{*}$ é o vetor da produção induzida;

$A$ é a matriz de coeficientes técnicos do Mercosul que permitem derivar a matriz inversa internacional de Leontief $(I-A)^{-1} \mathrm{e}$

$F$ é o vetor que representa a demanda final de cada país e as exportações para o resto do mundo.

A Tabela 7.1 sintetiza as quantidades de produção induzida pelas demandas finais de cada país e pelas exportações para o resto do mundo. A organização da tabela indica: nas linhas, o montante de produção de um determinado país que foi induzida pelas demandas finais de cada país parceiro; nas colunas, o montante de 
produção que a demanda final de um país induz sobre cada país parceiro; já a consistência dos cálculos pode ser verificada, comparando-se a coluna dos totais de produção induzida com a coluna dos totais de produção de cada país da Tabela 6.1. As diferenças eventualmente encontradas decorrem de arredondamentos e do nível de agregação da matriz.

Tabela 7.1 Produção agregada induzida pelas demandas finais e pelas exportações para o resto do mundo de cada país (US\$ milhões correntes de 1990).

\begin{tabular}{lrrrrrr}
\hline & Argentina & Brasil & Chile & Uruguai & $\begin{array}{r}\text { Resto do } \\
\text { mundo }\end{array}$ & Total induzido \\
\hline Argentina & 166857,35 & 1535,14 & 479,30 & 318,91 & 12127,55 & 181318,25 \\
Brasil & 3761,63 & 817548,48 & 1540,35 & 722,91 & 75336,52 & 898909,89 \\
Chile & 252,52 & 431,51 & 27387,41 & 26,81 & 9286,29 & 37384,54 \\
Uruguai & 266,25 & 592,28 & 35,76 & 7825,92 & 1829,34 & 10549,55 \\
\hline
\end{tabular}

Ainda, a quantificação da produção induzida causada pela demanda final da Tabela 7.1 permite, utilizando-se os valores das linhas, que se estabeleçam os graus de dependência doméstica e de dependência externa na produção $\left(D P^{r q}\right)$ do $r$-ésimo país sobre as demandas finais do $q$-ésimo país, ou seja,

$$
D p^{r q}=X^{* r q} / X^{* r}
$$

onde:

$r$ denota o país induzido e $q$, o país indutor;

$X^{*} r q$ é a produção induzida em $r$ pela demanda final de $q$ e

$X^{*} r$ é a produção induzida total em $r$.

Com esses cálculos, é possível examinar e distinguir o grau de influência que o comércio internacional e o comércio doméstico exercem na produção de um determinado país. Os resultados expressos na Figura 7.1 indicam que a dependência da produção dos países em relação à demanda externa apresenta dois padrões: um grupo 
com uma participação elevada da demanda externa (Chile e Uruguai) e outro com uma participação relativamente pequena (Argentina e Brasil).

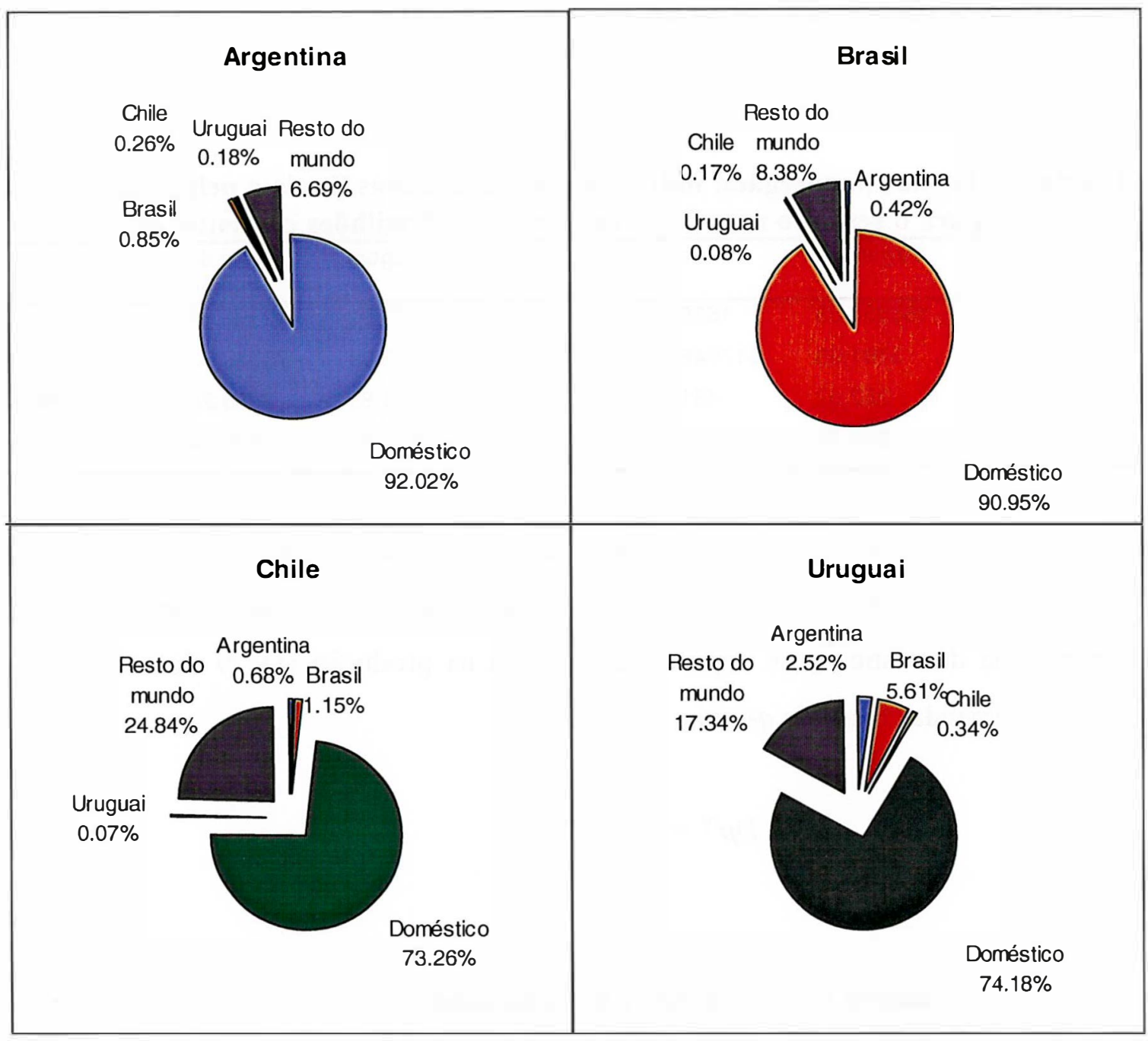

Figura 7.1 - Participação da produção agregada induzida pelas demandas finais e pelas exportações para o resto do mundo sobre o total de produção induzida de cada país.

O Chile mostra uma alta dependência em comparação com o Brasil e a Argentina, pois aproximadamente $27 \%$ da sua produção total é induzida através de exportações. O Uruguai apresenta níveis similares de dependência (24\%). Assim, para países com esse tipo de estrutura econômica, parece razoável a concepção de que o 
gerenciamento de suas economias domésticas deve ser implementado, levando em consideração os efeitos dos mercados externos. Por exemplo, quando os mercados internacionais adotam políticas protecionistas tarifárias ou não tarifárias, esses países sentem mais o impacto de tais políticas do que os outros. Assim, para amortecer tais efeitos nas estratégias do comércio internacional, há a necessidade de que esses países incrementem suas parcerias no mercado externo, priorizando o aumento da competitividade internacional de suas indústrias domésticas.

Nesse contexto, o padrão de dependência externa do Chile mostra que $1,15 \%$ de sua produção é induzida pelas exportações destinadas ao Brasil; $0,68 \%$, pelas exportações para a Argentina; $0,07 \%$, para o Uruguai e em torno de $25 \%$ através das exportações para o resto do mundo. Ainda, cabe mencionar que, na estrutura de exportações para o resto do mundo, não existe uma dependência específica concentrada num determinado país. Já o Uruguai, em relação ao Chile, mostra uma dependência maior com a Argentina (2,52\%) e com o Brasil $(5,61 \%)$, mas em menor grau com o resto do. mundo (17,34\%); contudo, sua dependência externa em geral caracteriza-se pelos mesmos padrões que o Chile apresenta.

A dependência da produção da Argentina (7,98\%) e do Brasil (9,05\%) por demanda externa apresenta um notório contraste com o Chile e o Uruguai. Porém, considerando-se que tanto a Argentina como o Brasil detêm uma dimensão econômica elevada, uma estrutura industrial diversificada e abundantes recursos naturais, essas características de economias fechadas não deveriam ser surpreendentes. Contudo, nos últimos tempos, também nesses países existem preocupações no sentido de que seja implementada uma maior inserção de suas economias no mercado internacional pelo fortalecimento da competitividade de suas indústrias domésticas. 


\subsubsection{Coeficiente da produção induzida da demanda final para cada país parceiro}

A questão é: em cada país-membro do Mercosul, quais são as características desses impactos na produção decorrentes de sua própria demanda final e das demandas finais dos países parceiros?

Para caracterizar esses impactos na produção, faz-se, então, uso dos coeficientes da produção induzida de demanda final para cada país. A definição do coeficiente de produção induzida da demanda final é

$$
\widetilde{\mathrm{X}}=(I-A)^{-1} F
$$

onde:

$\sum \widetilde{\mathrm{X}}$ é o somatório da produção induzida;

$\sum F$ é o somatório da demanda final e

$\Sigma \tilde{\mathrm{X}} / \sum F$ é definido como o coeficiente de produção induzida da demanda final.

Note-se, ainda, que os coeficientes são calculados como proporções da produção induzida por uma dada demanda final em relação ao somatório de todas as demandas finais. Em outras palavras, trata-se dos coeficientes agregados da matriz inversa internacional de Leontief.

Desse modo, os coeficientes da Tabela 7.2 mostram a produção de um país induzida por uma unidade adicional na demanda final de cada país. Assim, observase, entre todos os totais de coeficientes de produção induzidos, que o do Brasil é o mais elevado ( 1,984$)$ quando comparado com os dos outros países. O mesmo ocorre em relação aos coeficientes de produção doméstica $(1,979)$, localizados para cada país na diagonal da Tabela 7.2 e na participação relativa do coeficiente de produção doméstica sobre o coeficiente de produção total $(99,77 \%)$. Isso possibilita a afirmação de que 
aumentos na demanda final resultam em grandes aumentos na produção doméstica brasileira.

A estrutura de produção da Argentina, por sua vez, apresenta um coeficiente total $(1,587)$ e um coeficiente doméstico $(1,561)$ baixos em relação ao Brasil; a participação doméstica elevada $(98,37 \%)$, contudo, evidencia que há uma forte relação entre a demanda doméstica final e a produção doméstica, o que faz com que aumentos no consumo total de bens domésticos acarretem aumentos na produção das indústrias domésticas.

As inferências em torno da Argentina também são válidas para o Chile e o Uruguai, embora seja necessário ressaltar, em relação à Argentina, que os coeficientes totais e os coeficientes domésticos são maiores e as participações domésticas, menores.

Tabela 7.2 . Coeficiente de produção induzida da demanda final para cada país.

\begin{tabular}{l|cccc}
\hline & Argentina & Brasil & Chile & Uruguai \\
\hline Argentina & 1,56094 & 0,00288 & 0,01617 & 0,03623 \\
Brasil & 0,02275 & 1,97924 & 0,04478 & 0,06699 \\
Chile & 0,00184 & 0,00108 & 1,71959 & 0,00377 \\
Uruguai & 0,00124 & 0,00070 & 0,00130 & 1,72602 \\
\hline Total & 1,58677 & 1,98390 & 1,78183 & 1,83301 \\
\hline Participação doméstica \% & 98,37 & 99,77 & 96,51 & 94,16 \\
\hline
\end{tabular}

Finalmente, algumas características gerais podem ser destacadas sobre os impactos de produção das demandas finais dos países do Mercosul: a) os coeficientes de produção induzida total, ou capacidade de resposta das economias a uma variação das demandas finais, são diferenciados; b) as participações dos coeficientes de produção doméstica sobre o coeficiente de produção total são elevadas em todos os países parceiros, indicando que a capacidade de induzir a produção, em termos agregados, entre os países parceiros é limitada; c) nesse contexto, o Brasil e a Argentina lideram a capacidade de induzir maiores níveis de produção no Mercosul, isso, certamente, devido à dimensão, à diversificação e à complementariedade de seus mercados com os dos países parceiros. 


\subsubsection{Produção setorial induzida pelas demandas finais e pelas exportações para o resto do mundo de cada país}

Estabelecidas as características gerais das economias do Mercosul, cabe uma análise mais desagregada das relações entre as demandas finais e a produção dos diversos setores de cada país, a fim de se distinguir com maior clareza a individualidade das relações intersetoriais dos países. Com esse fim, a partir da equação (7.1), foi estimada a produção induzida pelas demandas finais de cada país e do resto do mundo, considerando-se, no entanto, oito grandes setores para cada país-membro do Mercosul. Em seqüência, utilizando-se esses resultados na equação (7.2), são calculados em nível setorial e para cada país, a participação da produção induzida pela demanda final doméstica sobre o total da produção induzida pela demanda final do país, dos países parceiros e exportações para o resto do mundo, denominada também como grau de dependência doméstica.

Como mostra a Figura 7.2, os níveis de dependência doméstica encontrados exibem características diferentes entre países com dimensão econômica grande (Argentina e Brasil) e aqueles com dimensão econômica pequena (Chile e Unuguai). Na Argentina e no Brasil, percebe-se, em geral, um grau de dependência doméstica elevado, porém uma comparação de seus setores primários indica diferenças substanciais. Por exemplo, a Argentina, dotada de recursos naturais apropriados para atividades agropecuárias, é um grande exportador de produtos agrícolas no mundo, portanto, sua demanda doméstica é baixa. Já o Brasil, apesar de seus recursos naturais abundantes, apresenta uma dependência doméstica alta no setor agropecuário, em virtude de sua produção ser destinada preponderantemente às indústrias de processamento do mercado interno. Com relação aos setores secundários e terciários, entretanto, não existem diferenças gritantes entre os dois países. 

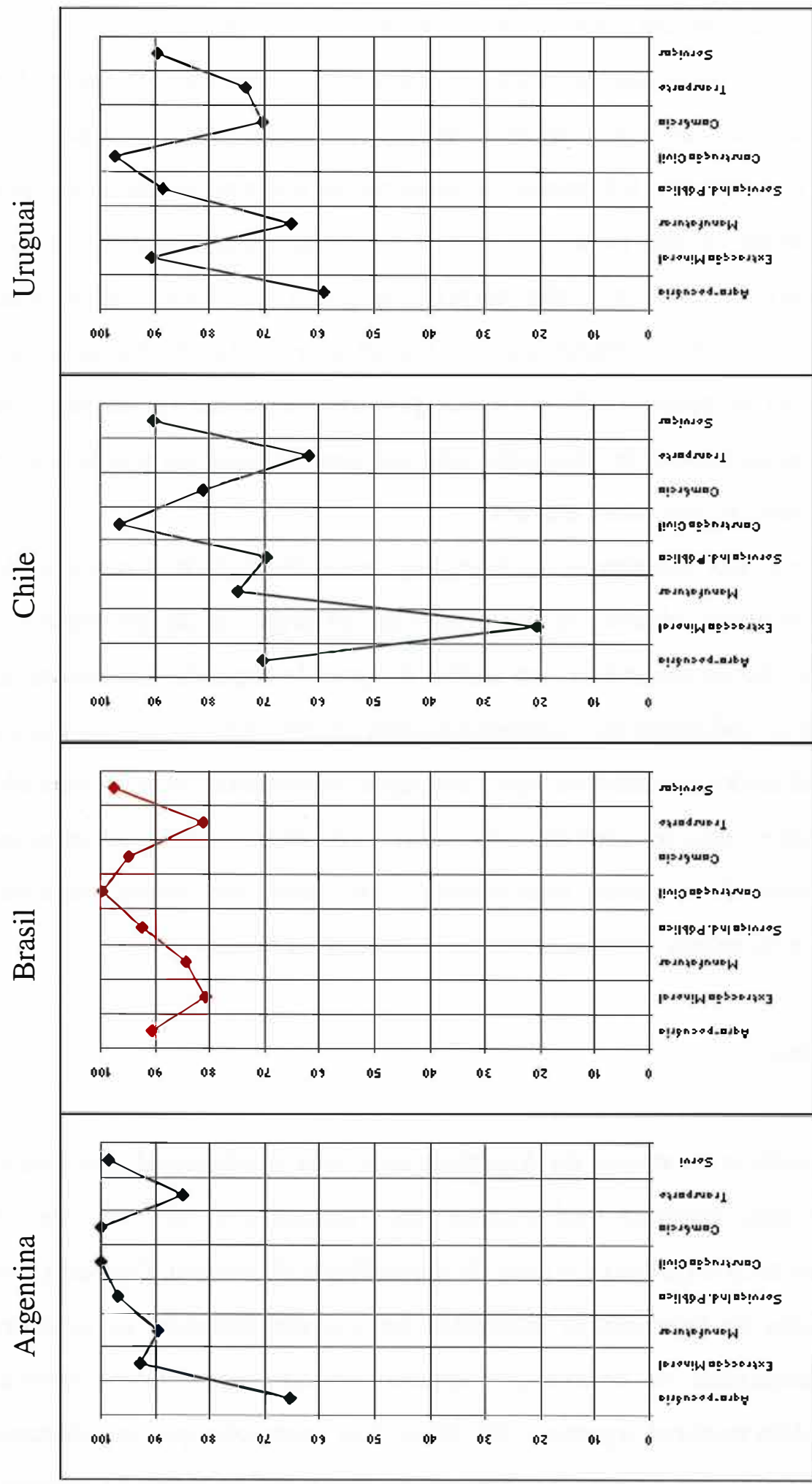

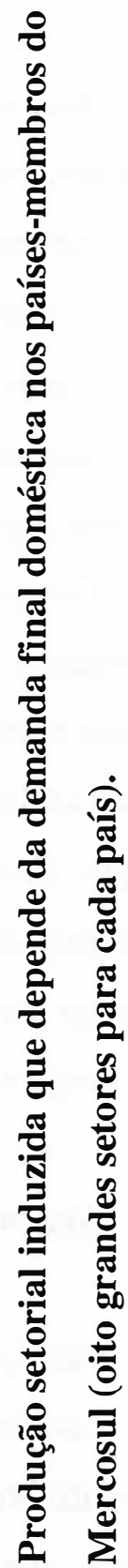


Por sua vez, no Chile e no Uruguai, a dependência doméstica, em geral, é relativamente baixa, se comparada com a da Argentina ou do Brasil, e o grau de dependência doméstica varia, às vezes, de forma considerável de um setor para outro. Em particular, a dependência é baixa nos setores da agropecuária, serviços industriais públicos, manufaturas e transporte. Entretanto, a indústria de mineração determina uma diferença fundamental entre os dois países, ou seja, a demanda doméstica do Chile por minérios é extremamente baixa, o que não surpreende posto que, neste setor, suas indústrias estão tradicionalmente voltadas para a exportação de tal forma que, nos últimos anos, o país vem se constituindo no maior produtor de cobre do mundo; em oposição, no Uruguai, as atividades de mineração não apresentam essas características, o que acarreta uma dependência doméstica elevada.

Em síntese, nas economias do Mercosul, pela diversidade dos níveis do grau de dependência doméstica, observa-se que o mercado externo, em alguns setores, é relevante. Nesse sentido, faz-se necessária uma análise do grau de dependência externa de cada país sobre as diversas indústrias que conformam cada um dos oito setores da Figura 7.2 , até porque, identificando as indústrias que têm laços importantes com o mercado externo, simultaneamente, está-se identificando setores produtivos que apresentam conhecimento ou "cultura de comércio internacional", os quais, em última instância, determinarão uma maior ou menor interdependência comercial na região.

\section{Argentina}

Para identificar os setores da Argentina com uma considerável quantidade de produção induzida pela demanda final externa, são relacionados, em nível de 31 setores, o produto bruto total argentino e o grau de dependência doméstica. Contudo, em razão dos níveis elevados de dependência doméstica setorial identificados, na presente análise, só foram considerados os setores que apresentam uma dependência setorial doméstica abaixo da média nacional argentina (92,02\%). Isso pressupõe que as indústrias a serem examinadas destinam uma parte importante de sua produção ao mercado externo. 


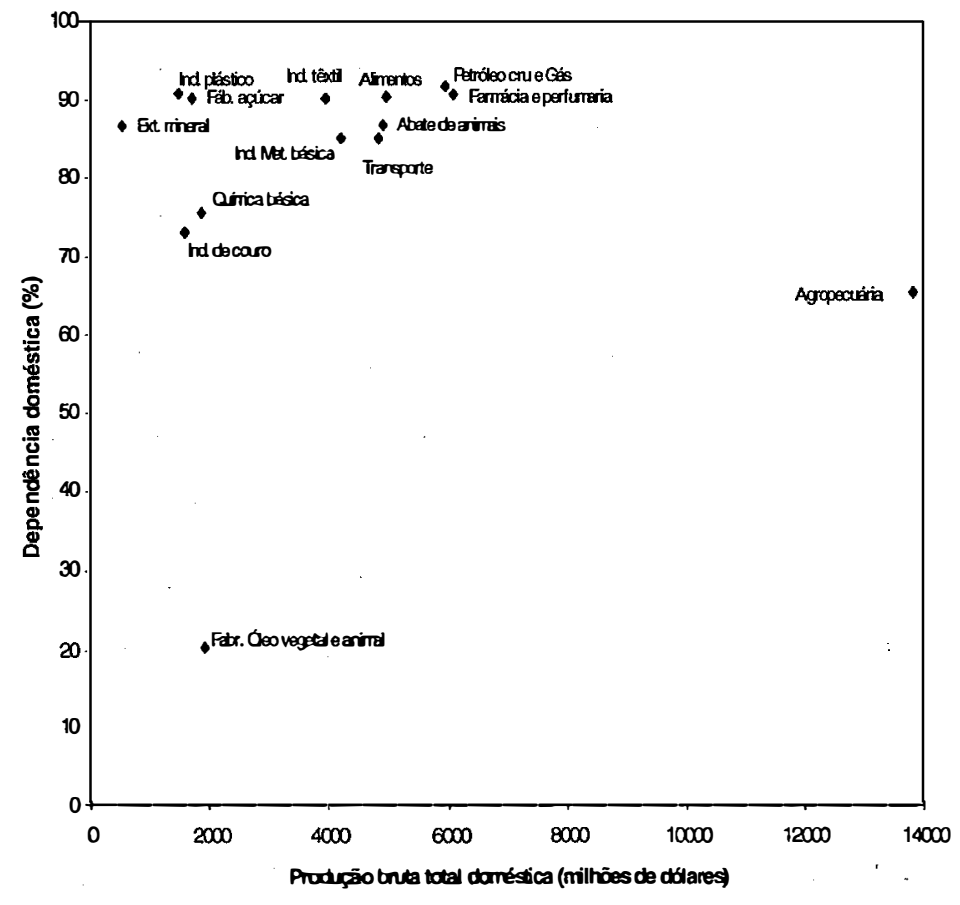

Figura 7.3 - Dependência setorial doméstica versus produção setorial na Argentina.

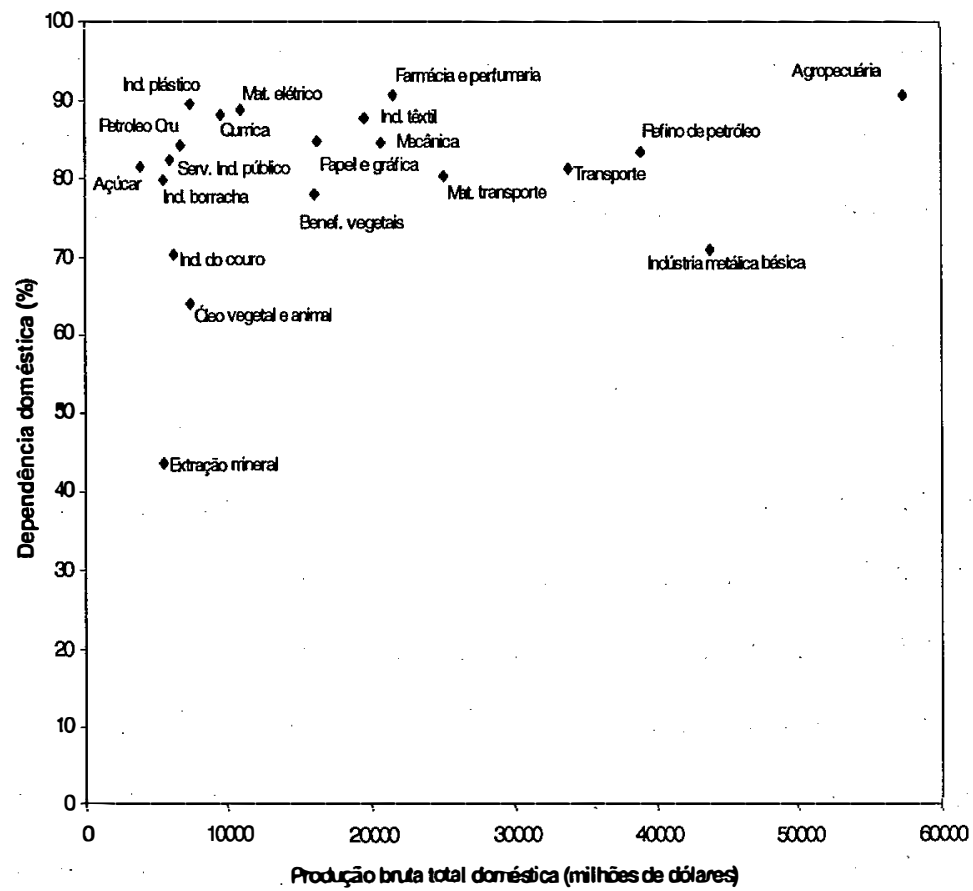

Figura 7.4 - Dependência setorial doméstica versus produção setorial no Brasil. 


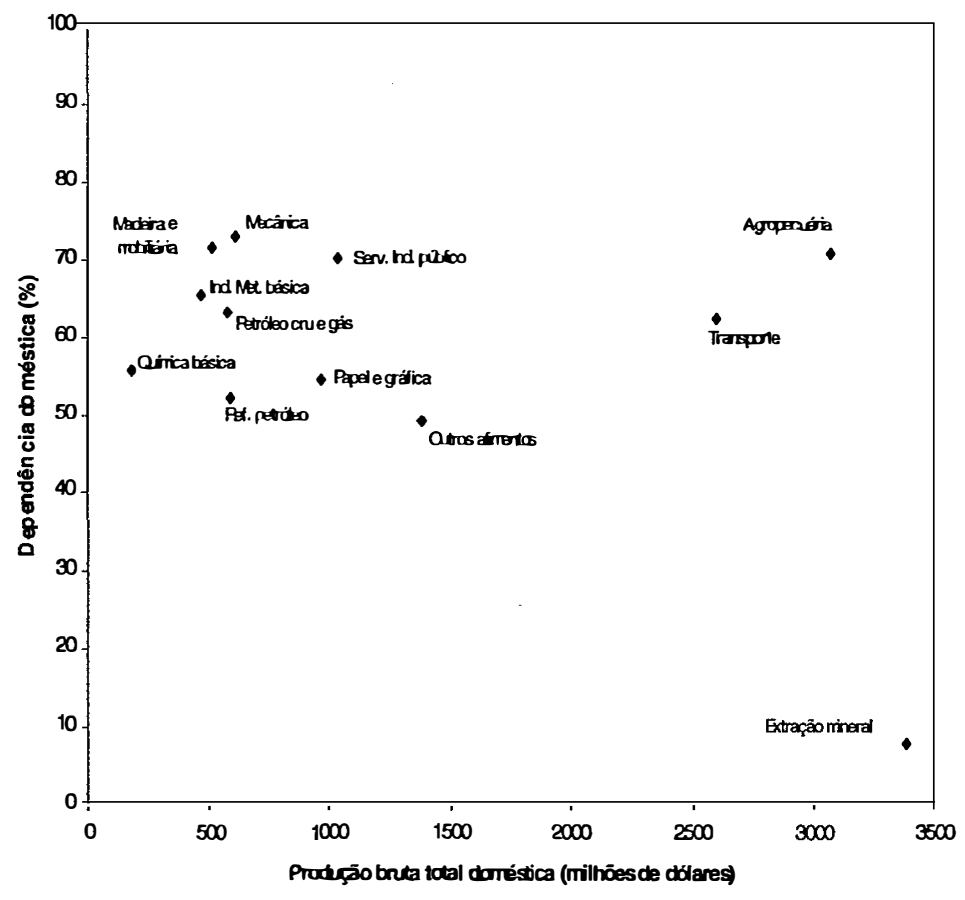

Figura 7.5 - Dependência setorial doméstica versus produção setorial no Chile.

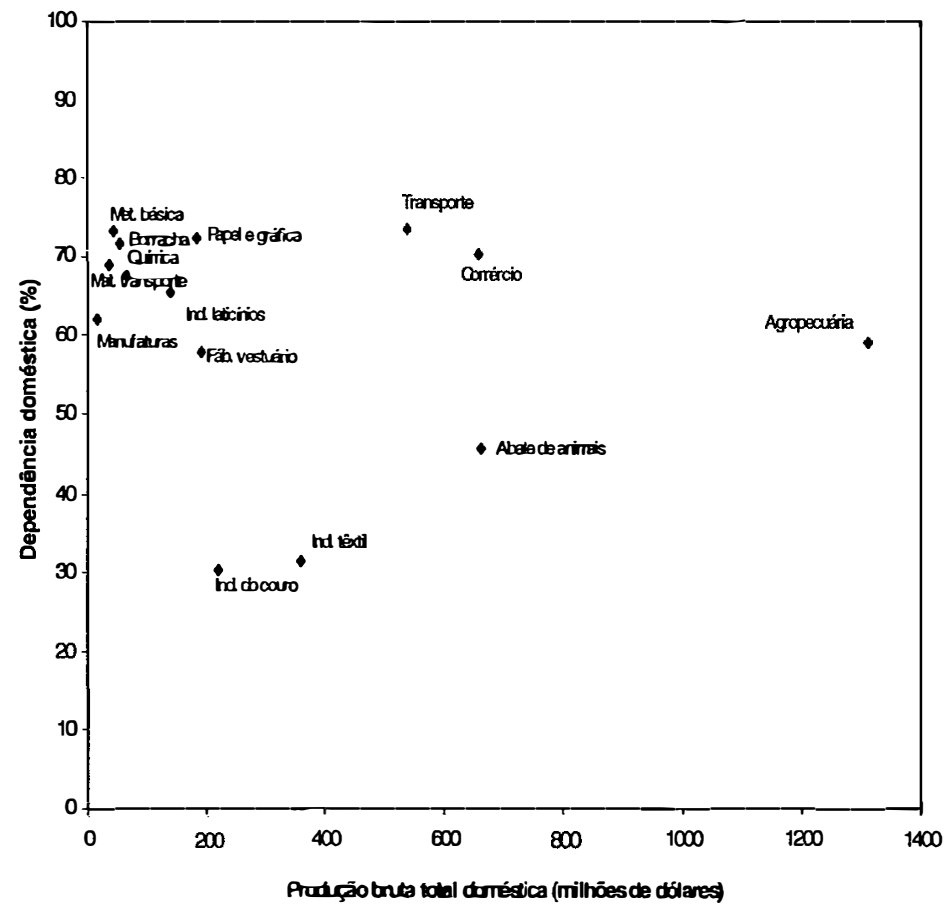

Figura 7.6 - Dependência setorial doméstica versus produção setorial no Uruguai. 
Dentre os setores da Argentina que destinam sua produção para o mercado externo, são quatorze os que se destacam. Na Figura 7.3, os setores localizados na extremidade inferior esquerda, tais como óleo vegetal e animal, têm um alto grau de dependência externa e contam com uma porção relativamente pequena da produção bruta total doméstica. Por sua vez, os setores com um baixo grau de dependência externa (ou elevada dependência doméstica) e que contam com uma pequena porção de produção bruta total doméstica, tal como o setor da indústria de extração mineral, estão localizados no lado superior esquerdo.

O setor agropecuário, no entanto, posicionado no lado superior direito, tem um papel extremamente importante nas exportações da Argentina uma vez que o grau de dependência externa é de $34,74 \%$ e seu volume de produção é elevado. Outros setores posicionadas no lado superior esquerdo, que dependem consideravelmente das exportações, são os de couro, química básica, metalúrgica, abate de animais, têxtil, outros alimentos, farmácia e perfumaria, etc. Contudo, deve-se notar que, em sua maioria, trata-se de setores que apresentam indústrias de recursos e/ou de processamento de recursos primários.

\section{Brasil}

Os critérios de seleção para os setores brasileiros são similares aos aplicados à Argentina, de maneira que, na Figura 7.4, aparecem os vinte setores que contam com uma grande porção da produção bruta e que também exibem níveis de dependência doméstica relativamente menores que a média brasileira $(90,94 \%)$.

Pelo número de setores identificados e o valor da produção, fica em evidência que as exportações brasileiras são diversificadas e que, entre as mais relevantes, por exemplo, se encontram a indústria metalúrgica básica, agropecuária, refino de petróleo, transporte, material de transporte, mecânica, têxtil, beneficiamento vegetal, couro, óleo vegetal e animal, química e extração mineral. Note-se, assim, que os setores de exportação não só estão limitados a setores de extração de matéria-prima de larga 
escala e a setores de processamento de matéria-prima, como também que existe, na verdade, um forte componente de setores que apresentam indústrias secundárias leves e pesadas de larga escala que estão vinculadas a setores-chave de sua economia.

Nesse contexto, pode-se afirmar que possíveis flutuações nas exportações brasileiras poderão afetar sua economia, contudo não devem criar problemas de crise nacional imediatos, já que existe uma pauta de exportações diversificada e uma dependência doméstica elevada.

\section{Chile}

Como indica a Figura 7.5, os setores chilenos com elevados níveis de dependência da demanda externa totalizam o número de doze, dos quais os que se destacam são extração mineral, transporte, agropecuária, petróleo cru e gás, outros alimentos, celulose e refino de petróleo. A maioria dessas atividades são de indústrias primárias ou de processamento de matérias cruas, cujas taxas de dependência de exportações são, em média, maiores que $42 \%$. Isso, combinado com o fato de que a produção total desses setores conta com, aproximadamente, $40 \%$ do produto bruto total doméstico chileno, deixa claro que flutuações do comércio exterior nas indústrias do setor primário ou de processamento primário criarão sérios problemas em sua economia, sobretudo se essas flutuações se concentrarem nas atividades de mineração (localizado no lado inferior direito da Figura 7.5), cuja produção bruta apresenta padrões internacionais de grande escala.

Nota-se, ainda, que os setores da Figura 7.5 apresentam um índice de dependência doméstica inferior à média setorial geral de Chile, que é de 73,26\%. Isso, comparado com os índices de dependência domésticos médios da Argentina (92,02\%) e do Brasil $(90,94 \%)$, indica que grande parte da economia chilena se desenvolve em função do mercado externo. 


\section{Uruguai}

As atividades com elevados níveis de dependência da demanda externa são setores de processamento de matérias-primas de origem vegetal e animal, das quais se destacam, na Figura 7.6, a indústria de couro, têxtil, abate de animais, agropecuária, vestuário e laticínios. $\mathrm{O}$ grau de dependência doméstica média do Uruguai $(74,18 \%)$ é similar ao do Chile, contudo sua pauta de exportações e o volume do produto bruto doméstico de cada setor não indicam atividades pesadas de larga escala. Talvez seja por isso que o setor comércio apresente uma taxa de dependência externa da ordem de $29,62 \%$.

Observa-se também que a taxa de dependência da pauta de exportações desses setores oscila em torno de $40 \%$ e que sua participação relativa no produto bruto total doméstico é de $42,45 \%$. Assim, as inferências sobre o comércio exterior do Chile são válidas também para o Uruguai, especialmente se ocorrem nas atividades agropecuárias que, simultaneamente, são abastecedores de matéria-prima de suas indústrias processadoras.

\subsubsection{Importância relativa dos fluxos de comércio internacional para a produção induzida nos países do Mercosul}

Com base na Figura 7.1, mencionou-se, em termos agregados, que a dependência externa total da Argentina e do Brasil é pequena e que a do Chile e do Uruguai é relativamente maior. Afirmou-se também que a dependência externa dos países com o Mercosul, exceto a do Uruguai, é extremamente limitada se comparada à do resto do mundo. No entanto, em razão dos consideráveis níveis de dependência externa identificados em alguns setores (Figuras 7.3 a 7.6), faz-se necessário, em termos de efeitos diretos e indiretos na produção, qualificar melhor a importância relativa dos fluxos do comércio internacional dos países do Mercosul. 
Para isso, por exemplo, comparar-se-á a quantidade de produção induzida na Argentina pela demanda final do Brasil $\left(X^{* \alpha \beta}\right)$ com a quantidade das exportações que a Argentina fez para o Brasil $\left(A^{\alpha . \beta}\right)$, ou seja:

$$
X^{* \alpha \beta} / A^{\alpha \beta}
$$

devendo ser lembrado que $\alpha$ denota a Argentina e $\beta$, o Brasil.

Com essa proporção, é possível mensurar a importância relativa do mercado brasileiro para as exportações argentinas em termos de efeitos diretos e indiretos. Os resultados desses cálculos para todos os países do Mercosul em relação ao comércio inter-regional e com o resto do mundo são dados na Figura 7.7.

Em geral, as estruturas de transações dos países mostram que existe uma hierarquia na importância relativa dos fluxos de exportações na região (o padrão médio de importância no Mercosul, sem incluir o resto do mundo, é: para o Brasil, 2,2; para o Uruguai, 1,8 e, para o Chile e Argentina, 1,6 cada um). Em decorrência disso, produz-se uma distribuição assimétrica nos impactos econômicos que os países se concedem, particularmente entre o Brasil e a Argentina, os quais são analisados a seguir.

Por um lado, a produção induzida na economia brasileira, por causa da demanda final dos países parceiros e do resto do mundo, é a mais ampla já que está entre 2 a 2,3 vezes o tamanho das exportações do Brasil. Contrariamente, o efeito na produção induzida dos países parceiros derivada da demanda final brasileira é consideravelmente mais baixo em relação àquela que lhe é concedida: para a Argentina, 1,5; para o Chile, 1,4 e, para o Uruguai, 1,7 vezes o volume de suas respectivas exportações que fazem ao Brasil. Certamente, esse comportamento se deve às diferenças existentes entre as estruturas de exportação do Brasil e de seus países parceiros: enquanto o volume das exportações brasileiras é de produtos industriais pesados e leves que têm grande repercussão na produção em virtude do valor adicionado, as exportações dos países parceiros são, predominantemente, de recursos naturais e produtos primários processados, que têm efeitos de ligações relativamente fracas. 


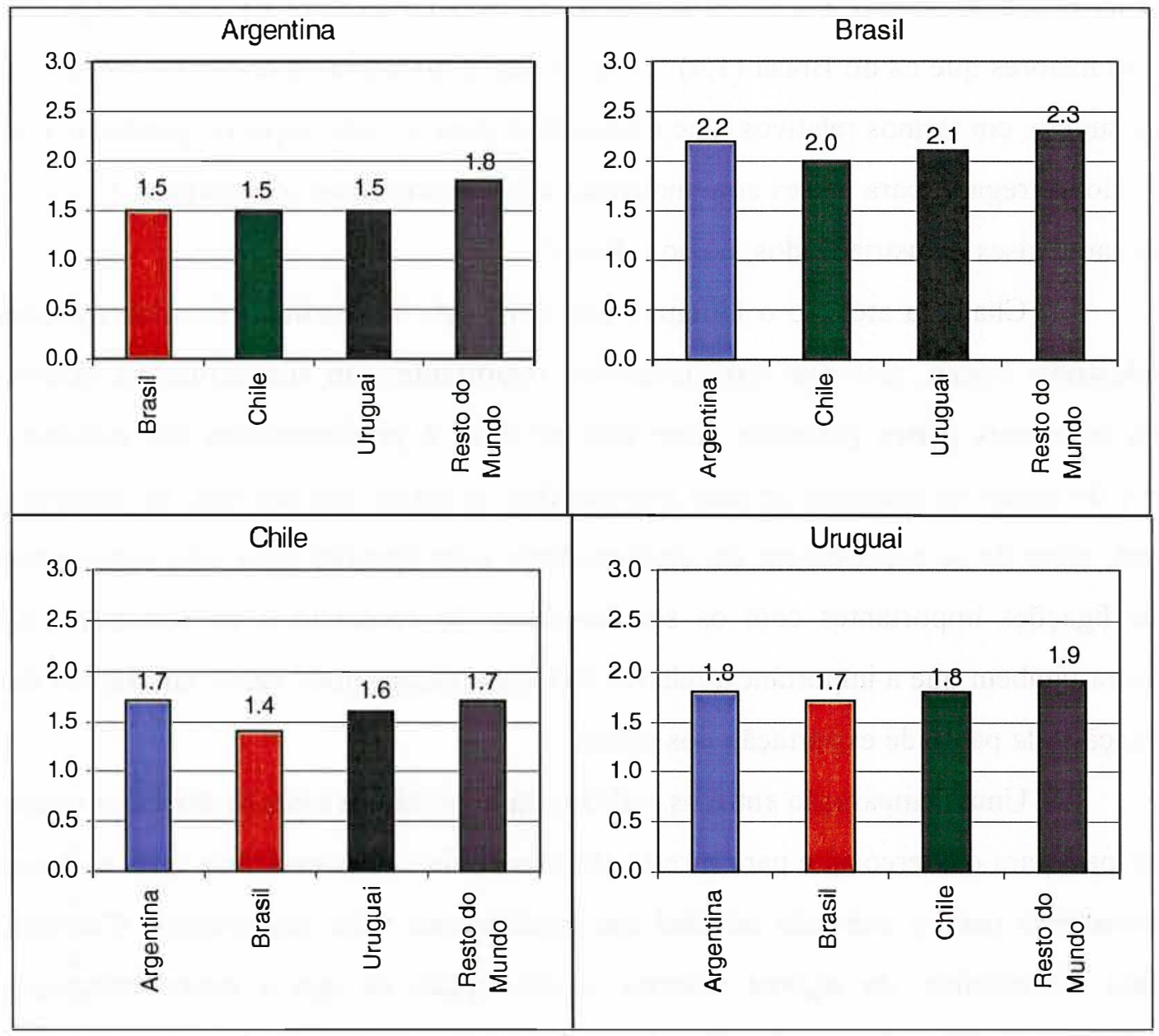

Figura 7.7 - Participação da produção induzida pelas demandas finais e pelas exportações para o resto do mundo sobre as exportações de cada país.

Por sua vez, a importância relativa das exportações argentinas para todos os países coincide em 1,5, e o efeito na produção induzida que este país concede aos demais é, particularmente, o mais elevado dentro do Mercosul: para o Brasil, 2,2; para o Chile, 1,6, e, para o Uruguai, 1,8 vezes o tamanho de suas respectivas exportações destinadas à Argentina. Portanto, pode-se afirmar que, na pauta de exportação de 1990, os efeitos dos fluxos de exportação destinados para a Argentina repercutem com maior força benéfica nas economias dos países parceiros.

A importância relativa dos mercados da região para as exportações chilenas se assenta num padrão médio $(1,6)$ semelhante ao da Argentina; contudo, os 
efeitos na produção induzida que lhe é concedida pelo Uruguai $(1,6)$ e pela Argentina $(1,6)$ são maiores que os do Brasil $(1,4)$. Note-se que a estrutura de dependência externa setorial sugere, em termos relativos, que é mais fácil para o Chile exportar produtos com maior valor agregado para países com indústrias não consolidadas (Argentina e Uruguai) do que para países industrializados, como o Brasil.

Chama a atenção o Uruguai, que apresenta um padrão médio de ligações interindustriais fracas, mas que tem beneficios importantes em sua economia quando exporta para seus países parceiros. Esse fato se deve à predominância das indústrias têxteis e de couro na estrutura de suas exportações, as quais, por sua vez, na economia uruguaia, além de se constituírem em setores-chave com ligações para trás, apresentam elos de ligações importantes com os setores-chave de comércio e de serviços. Isso demonstra também que a importância relativa das exportações pode variar em função das modificações da pauta de exportação dos países.

Uma comparação entre os padrões da importância relativa das exportações de cada país para o Mercosul e para o resto do mundo deixa em evidência que os fluxos de mercadorias para o mercado mundial são ligeiramente mais importantes. Contudo, esse fato desmistifica, de alguma maneira, a concepção de que a maior integração espacial com o resto do mundo (Tabelas 6.2 e 6.3 e Figuras 6.1 e 6.2) implica, necessariamente, uma importância relativa nos mesmos níveis. Na verdade, em termos de efeitos diretos e indiretos, tudo dependerá da pauta de exportação associada a setoreschave de cada país.

Nesse sentido, resta identificar na pauta de exportações inter-regionais do Mercosul em quanto as demandas finais de um país contribuem para a produção dos diferentes setores de seus países parceiros. Com esse fim, inicialmente, a partir da equação (7.1), foi estimada exclusivamente a produção induzida pelas demandas finais de cada país parceiro, porém considerando 31 setores para cada um. Após, utilizando os resultados na equação (7.2), calcularam-se as contribuições das demandas finais de cada país sobre seus respectivos parceiros. Os resultados finais são apresentados na Tabela 7.3. 


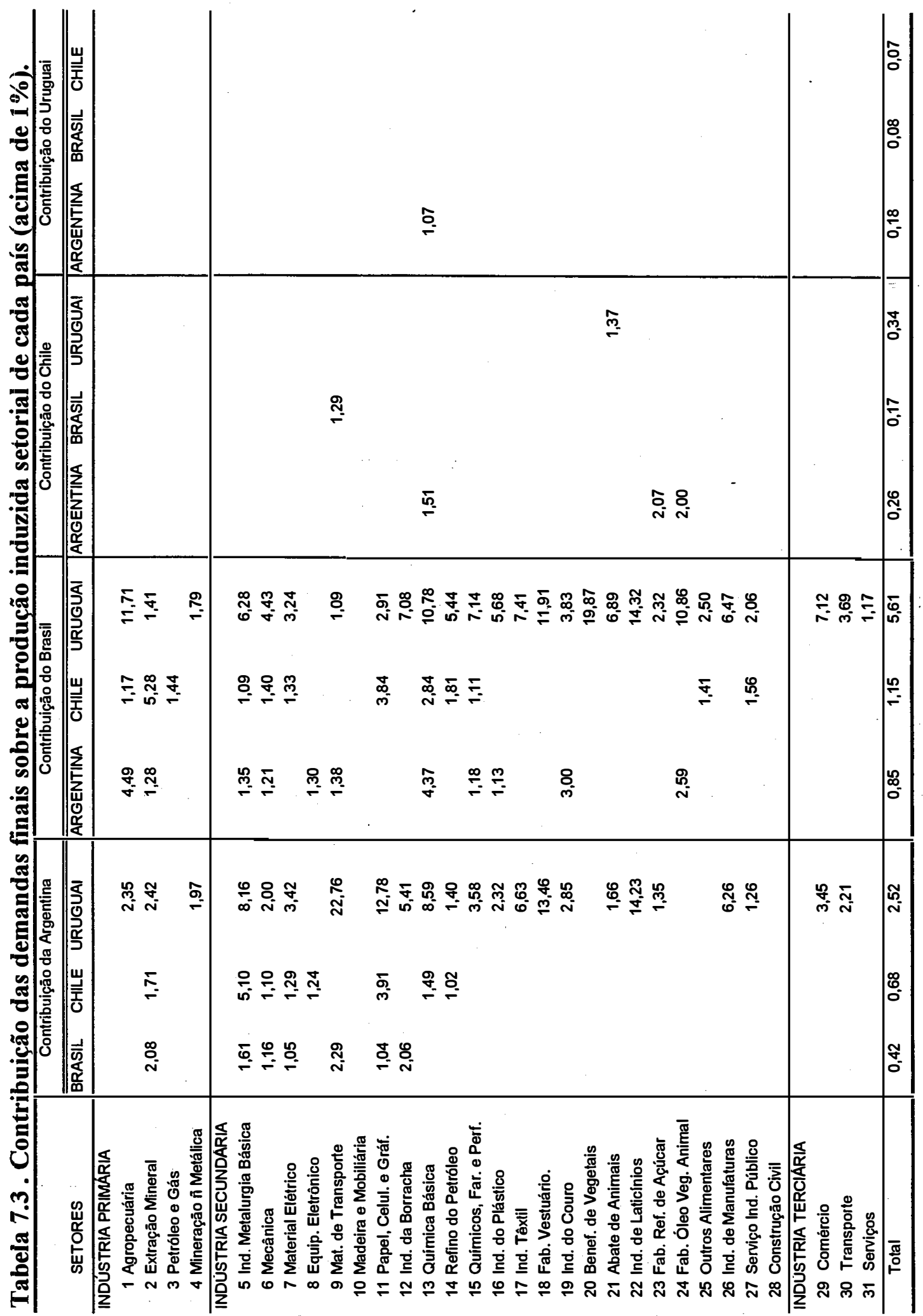


Observa-se que as economias da Argentina e do Brasil induzem as maiores quantidades na produção em relação a seus países parceiros, sendo essas contribuições diferenciadas de setor para setor. Por exemplo, a Argentina induz a produção brasileira e chilena no setor primário de extração mineral e, principalmente, em setores que apresentam indústrias secundárias pesadas, tais como metalúrgica básica, mecânica, material elétrico, equipamento eletrônico, material de transporte, celulose, borracha, química e refino de petróleo. Já, no caso do Uruguai, a produção induzida pela demanda final argentina é significante em quase todos os setores que compreendem as indústrias do setor primário, secundário e terciário. Certamente, nesse país, as contribuições argentinas se tornam mais evidentes devido à sua pequena dimensão econômica e, também, por tratar-se de um país que apresenta uma maior dependência externa com o Mercosul, além de ựa maior vizinhança geográfica de seu pólo central de crescimento (Montevidéu) com o da Argentina (Buenos Aires).

O Brasil, por outro lado, induz níveis de produção setorial bem mais diversificados que os da Argentina; entretanto, os setores primários de recursos naturais e de processamento de recursos são predominantes, especialmente nos setores agropecuários e extração vegetal, extração mineral, química, refino de petróleo, couro, celulose e óleo vegetal e animal. A contribuição do Brasil sobre o Uruguai, em virtude do volume de comércio, é significativa e se mostra superior às contribuições da Argentina.

A contribuição do Uruguai, por sua vez, só é significativa através das indústrias do setor química, uma vez que esta atividade na economia do país está relacionada de forma direta com setores de produção e de processamento de matériasprimas de origem agropecuária.

Quanto às contribuições de Chile e Uruguai na indução da produção, essas podem ser consideradas marginais. As indústrias com que o Chile contribui significativamente são material de transporte, química, abate de animais, açúcar e óleo vegetal e animal. 
Em síntese, as características gerais encontradas no comércio interregional permitem afirmar que: a) a Argentina e o Brasil lideram as alterações econômicas na região; b) enquanto a economia argentina induz à produção em setores secundários de ligações interindustriais relativamente fortes, o Brasil induz à produção em setores de recursos naturais e de processamento de recursos, com ligações interindustriais relativamente fracas; c) para o Chile e Uruguai, é conveniente a intensificação de uma maior interdependência setorial na região por causa dos impactos benéficos e diversificados que as ligações interindustriais geram em suas economias.

\subsection{Demandas finais e valor adicionado}

Na seção anterior, foram analisadas, por meio do enfoque da produção induzida, as características das transações comerciais de cada país, bem como a dependência mútua que existe entre suas indústrias. As análises implementadas mostram, na produção agregada induzida pelas demandas finais dos padrões diferenciados, uma participação elevada da demanda externa nas economias do Chile e do Uruguai e relativamente pequena nas economias da Argentina e do Brasil; no entanto, em virtude da dimensão econômica, estes últimos lideram a capacidade de induzir maiores níveis de produção no Mercosul. Os coeficientes de produção induzida indicaram que aumentos na demanda final dos países resultam em grandes aumentos na produção doméstica. Nesta seção, examinar-se-á que tipo de impactos tais ligações industriais têm na geração de valor adicionado induzido, ou seja, as características do valor adicionado induzido pelas demandas finais de cada país.

\subsubsection{Valor adicionado agregado induzido pelas demandas finais e pelas exportações para o resto do mundo de cada país}

O valor adicionado induzido pode ser obtido subtraindo-se da produção induzida os valores dos insumos intermediários: 


$$
V^{*}=\hat{V}(I-A)^{-1} F
$$

onde:

$V^{*}$ é o vetor do valor adicionado induzido;

$\hat{V}$ é a matriz diagonalizada das proporções do valor adicionado para o total de insumos $\left(\hat{V}_{j}=V_{j} / X_{j}\right)$;

$A$ é matriz de coeficientes técnicos do Mercosul e

$F$ é o vetor da demanda final de cada país.

Assim, o valor adicionado induzido pode ser obtido pela multiplicação da proporção do valor adicionado pela produção induzida.

A Tabela 7.4 resume as quantidades de valor adicionado induzido pelas demandas finais de cada país e pelas exportações para o resto do mundo: as colunas mostram quanto valor adicionado as demandas finais de um dado país geraram em cada país parceiro; as linhas indicam quanto valor adicionado de um determinado país foi induzido pelas demandas finais de cada país e pelas exportações para o resto do mundo.

Tabela 7.4 . Total valor adicionado induzido pela demanda final de cada país e do resto do mundo, em milhões de dólares correntes de 1990.

\begin{tabular}{lrrrrrr}
\hline & Argentina & Brasil & Chile & Uruguai & $\begin{array}{r}\text { Resto do } \\
\text { mundo }\end{array}$ & Total \\
\hline Argentina & 103680 & 868 & 237 & 152 & 6571 & 111508 \\
Brasil & 1436 & 397515 & 570 & 272 & 30400 & 430193 \\
Chile & 109 & 201 & 13226 & 11 & 4319 & 17866 \\
Uruguai & 116 & 273 & 16 & 3863 & 824 & 5092 \\
\hline Total & 105340 & 398857 & 14049 & 4298 & 42114 & 564658 \\
\hline Demanda final & 109615 & 426187 & 18027 & 4980 & 46433 & 605242 \\
\hline
\end{tabular}

A partir da Tabela 7.4, é possível identificar os níveis de dependência do valor adicionado $\left(D v^{r s}\right)$ do $r$-ésimo país sobre as demandas finais do $s$-ésimo país (Tabela 7.5),

$$
D v^{r s}=V^{* r s} / V^{*}
$$


onde:

$r$ denota o país indurido e $s$ é o país indutor;

$V^{* r s}$ é o valor adicionado induzido em $r$ pela demanda final de $s$ e

$V^{* r}$ é o valor adicionado induzido total em $r$.

Tabela 7.5 . Dependência do valor adicionado induzido pela demanda final de cada país e do resto do mundo, em percentuais.

\begin{tabular}{lrrrrrr}
\hline & Argentina & Brasil & Chile & \multicolumn{2}{c}{ Uruguai Resto do mundo } & Total \\
\hline Argentina & 92,98 & 0,78 & 0,21 & 0,14 & 5,89 & 100,00 \\
Brasil & 0,33 & 92,40 & 0,13 & 0,06 & 7,07 & 100,00 \\
Chile & 0,61 & 1,12 & 74,03 & 0,06 & 24,17 & 100,00 \\
Uruguai & 2,27 & 5,36 & 0,31 & 75,87 & 16,19 & 100,00 \\
\hline
\end{tabular}

As contribuições dos países para o valor adicionado induzido na Figura 7.8, obtidas da Tabela 7.5, evidenciam dois padrões de comportamento diferenciados no Mercosul: dependência das demandas finais domésticas elevadas na Argentina (92,98\%) e no Brasil $(92,40 \%)$ e demandas relativamente baixas no Chile $(74,03 \%)$ e no Uruguai $(75,87 \%)$. Isso, associado aos padrões de comportamento semelhantes que apresenta a produção induzida doméstica da Figura 7.1, permite afirmar, em termos relativos, que a influência exercida pelo comércio internacional sobre as atividades econômicas da Argentina e do Brasil é pequena e, sobre o Chile e o Uruguai, é elevada.

A Figura 7.9, onde é plotada, para cada país, a produção doméstica total per capita e a dependência doméstica do valor adicionado (participação do valor adicionado induzido doméstico de um determinado país sobre o total de valor adicionado que o mesmo gera com sua demanda final, Tabela 7.4), permite, ainda, caracterizar, se associado o nível de desenvolvimento industrial dos países, a possível tendência do comércio inter-regional. Isso porque, modificações na estrutura de dependência doméstica do valor adicionado de um país implicam mudanças em seus processos de produção, em suas relações intersetoriais nacionais e/ou internacionais e, finalmente, em sua produção total per capita. Certamente, dependendo do nível de desenvolvimento 
econômico, a relação entre dependência doméstica e produto per capita que pode ser direta ou inversamente proporcional, indicará as tendências do comércio na região.

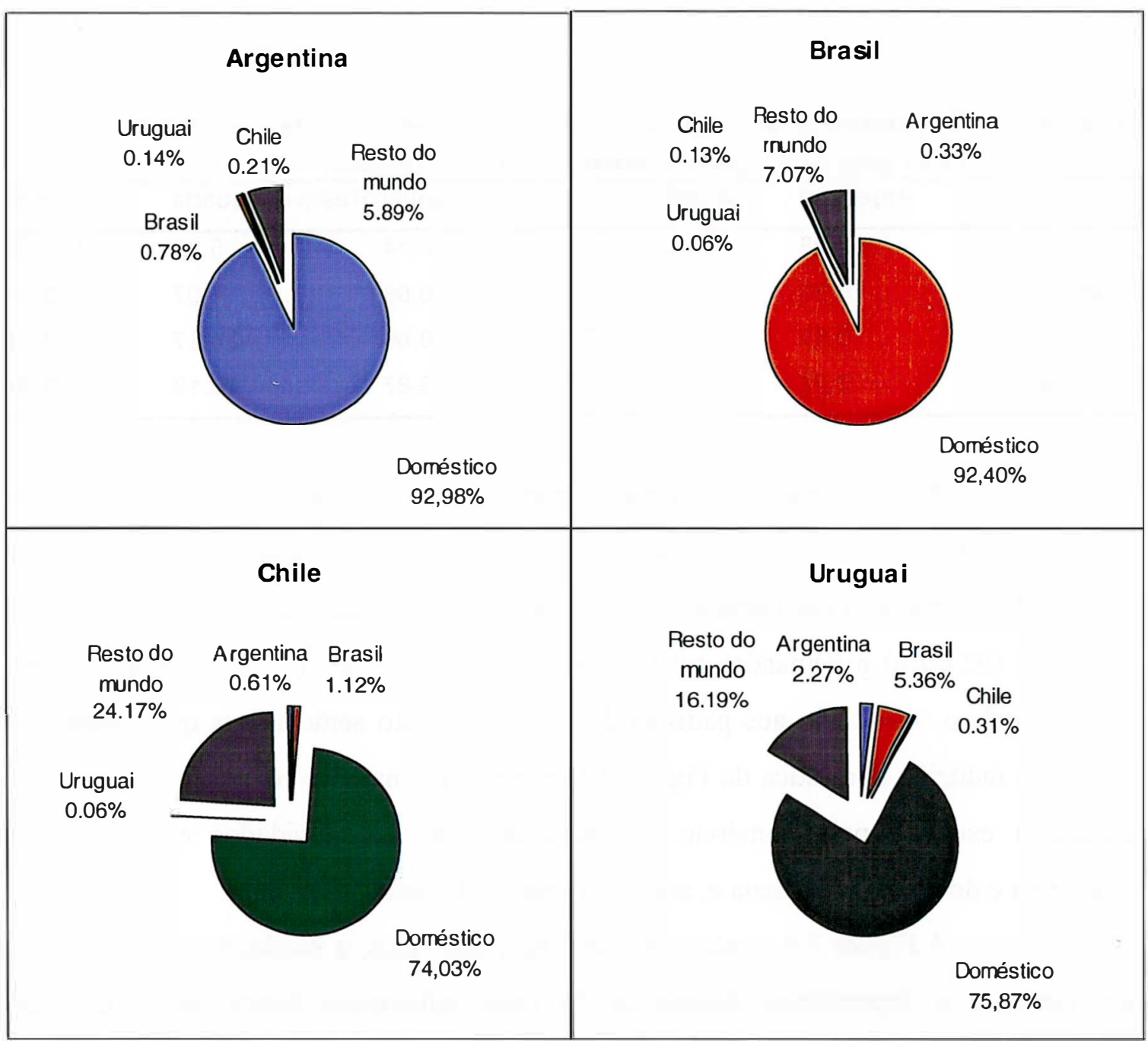

Figura 7.8 - Participação do valor adicionado induzido pelas demandas finais e pelas exportações para o resto do mundo sobre o total de valor adicionado induzido de cada país.

Nesse contexto, notam-se três características adicionais: primeiro, entre os países com dimensões econômicas pequenas e um nível de industrialização menor (Chile e Uruguai), a produção doméstica total per capita de cada país e a dependência doméstica do valor adicionado são inversamente relacionadas; segundo, dentre os países de dimensões econômicas elevadas e um nível de industrialização maior (Argentinae Brasil), 
o inverso é verdadeiro, ou seja, a produção doméstica total per capita e a dependência doméstica do valor adicionado estão positivamente correlacionadas; terceiro, os níveis de produção doméstica total per capita são mais elevados no segundo grupo de países (Argentina e Brasil) que no primeiro grupo (Chile e Uruguai).

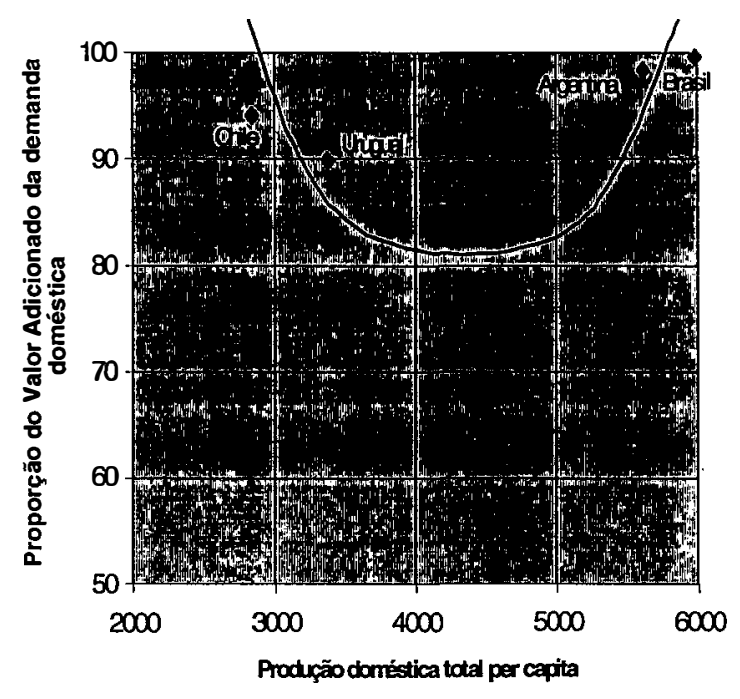

Figura 7.9 - Padrão de dependência e produção doméstica dos países do Mercosul.

Esses dados, associados à "tendência de uma linha média" mostrada na Figura 7.9, indicam que economias, tais como as do Chile e Uruguai, devido à imaturidade que apresentam nos setores de materiais básicos industriais, normalmente importam bens de capital e materiais intermediários para estimular a produção de suas indústrias que estão orientadas para a exportação. Certamente, à medida que se intensifica esse processo, espera-se uma diminuição da dependência doméstica do valor adicionado já que as importações desse tipo de mercadorias são incrementadas. Contudo, se, simultaneamente, as economias chilena e uruguaia vêm alcançando, graças às importações de bens de capital e materiais intermediários, um certo nível de desenvolvimento industrial que aumenta a produção total per capita, como, por exemplo, o da Argentina, a estrutura econômica torna-se mais articulada e a demanda por materiais básicos industriais aumenta. Nessas circunstâncias, programas de substituição de 
importações, como aquele que foi aplicado no Brasil, podem aumentar a rede de suprimentos domésticos; em conseqüência, a economia torna-se mais orientada pelas atividades de serviço (a participação relativa do setor serviços no valor da produção nacional tende a se incrementar), o peso relativo do mercado internacional diminui (a dependência doméstica do valor adicionado aumenta) e as ligações interindustriais domésticas para frente e para trás se intensificam e/ou estreitam.

Se os padrões da Figura 7.9 fossem usados para prever a tendência das economias do Mercosul, a dependência externa do Chile e do Uruguai nos próximos anos, em termos relativos, provavelmente aumentaria bem mais que a dependência externa da Argentina e o do Brasil. Portanto, as perspectivas de uma maior interdependência comercial nas regiões, em virtude da complementariedade de suas economias, são promissoras a menos que a estrutura e o nível do comércio se alterem drasticamente.

\subsubsection{Coeficiente do valor adicionado induzido pela demanda final de cada país parceiro}

Ainda com base na Tabela 7.4, pode-se estabelecer o coeficiente do valor adicionado induzido pela demanda final $\left(C V T^{F}\right)$, definido da seguinte maneira:

$$
C V V^{F r}=V^{* s} / F^{s}
$$

onde:

$$
\begin{aligned}
& r \text { denota o país induzido e } s \text { o país induzidor; } \\
& V^{* s} \text { é o valor adicionado induzido em } r \text { pela demanda final de } s \text { e } \\
& F^{s} \text { é a demanda final de } s,
\end{aligned}
$$

isto é, a divisão do valor adicionado que induz a demanda final de um país pela respectiva demanda final do mesmo. 
Os coeficientes do valor adicionado da Tabela 7.6 permitem analisar em quanto o valor adicionado é induzido por uma unidade adicional de demanda final para cada país. Nela, as colunas mostram a quantia do valor adicionado induzido em cada país por unidade de demanda final de um certo país. Por exemplo, uma unidade adicional na demanda final do Uruguai induzirá um aumento no valor adicionado de 0,7757 unidades em sua economia; de 0,0305 na Argentina; de 0,0546 no Brasil e de 0,0022 no Chile, o que perfaz um total de 0,8631 unidades nos quatro países.

Tabela 7.6 . Coeficiente do valor adicionado induzido pela demanda final para cada país.

\begin{tabular}{lcccccc}
\hline & Argentina & Brasil & Chile & Uruguai & $\begin{array}{r}\text { Resto do } \\
\text { mundo }\end{array}$ & Total \\
\hline Argentina & 0,9459 & 0,0020 & 0,0131 & 0,0305 & 0,1415 & 0,1842 \\
Brasil & 0,0131 & 0,9327 & 0,0316 & 0,0546 & 0,6547 & 0,7108 \\
Chile & 0,0010 & 0,0005 & 0,7337 & 0,0022 & 0,0930 & 0,0295 \\
Uruguai & 0,0011 & 0,0006 & 0,0009 & 0,7757 & 0,0178 & 0,0084 \\
\hline Total & 0,9610 & 0,9359 & 0,7793 & 0,8631 & 0,9070 & 0,9329 \\
\hline Demanda final & 1,0000 & 1,0000 & 1,0000 & 1,0000 & 1,0000 & 1,0000 \\
\hline
\end{tabular}

Antes de continuar a análise, algumas considerações sobre os coeficientes do valor adicionado induzido devem ser feitas. Se não houvesse comércio com o resto do mundo, o valor adicionado para os quatro países seria igual a suas respectivas demandas finais e o coeficiente total desses seria igual a 1. Certamente, isso não ocorre na matriz do Mercosul, porque os denominados paises resto do mundo existem, sendo, no modelo, tratados como exógenos. Entretanto, numa matriz insumo-produto para todo o mundo, as exportações e importações mundiais deveriam ser iguais; portanto, o coeficiente total mundial tornar-se-ia 1.

Entendidas essas características básicas do coeficiente do valor adicionado induzido, nota-se, na Tabela 7.6, que o coeficiente total mais alto é o da Argentina $(0,9610)$. Desse, o coeficiente doméstico é 0,9459 e todos os coeficientes dos países parceiros se igualam a 0,0151 . Quanto ao coeficiente total do Brasil, é o segundo mais 
alto $(0,9359)$, do qual o coeficiente doméstico é 0,9327 ; os coeficientes dos países restantes somam 0,0031. Em ambos os casos, as porções de valor adicionado induzido sobre os países parceiros são pequenas, principalmente a do Brasil, que é cinco vezes menor que a da Argentina.

Por outro lado, o Chile tem um coeficiente total de somente 0,7793 , do qual o coeficiente doméstico é de 0,7337 e o somatório dos coeficientes restantes ascendè a 0,0456 . Com base nisso, pode-se afirmar que as porções de valor adicionado induzido sobre os países parceiros são grandes, visto que representam de três e quatorze vezes a capacidade de indução da Argentina e do Brasil, respectivamente.

No caso uruguaio, o coeficiente total apresenta um nível intermediário entre a Argentina e o Chile, porém sua capacidade de induzir valor adicionado na região é relativamente superior em relação a todos os países parceiros.

Nesse contexto, uma característica comum da Argentina, Chile e Uruguai é que os coeficientes de valor adicionado induzido com relação ao Brasil são os mais altos. Esse fato, associado aos níveis de industrialização alcançados pelo Brasil, mostra a importância relativa da economia brasileira como um supridor de produtos acabados, de matérias básicas industriais e de bens de capital para os países do Mercosul. Assim, tornase claro que, à medida que o processo de desenvolvimento seja implementado na região, acompanhado de uma maior interdependência industrial, o nível do valor adicionado no Brasil aumentará.

Cabe salientar que os coeficientes do valor adicionado induzido pelos países parceiros sobre a Argentina são os segundos mais altos, entretanto, na atual estrutura das transações, os niveis de valor adicionado não devem ser tão expansivos quanto os do Brasil, uma vez que a industrialização ampla de sua economia não está consolidada. Enfim, a Figura 7.10, na qual estão plotadas as proporções de dependência doméstica (Tabela 7.5) e o coeficiente do valor adicionado induzido doméstico (Tabela 7.6), permite sintetizar a análise até aqui implementada. 


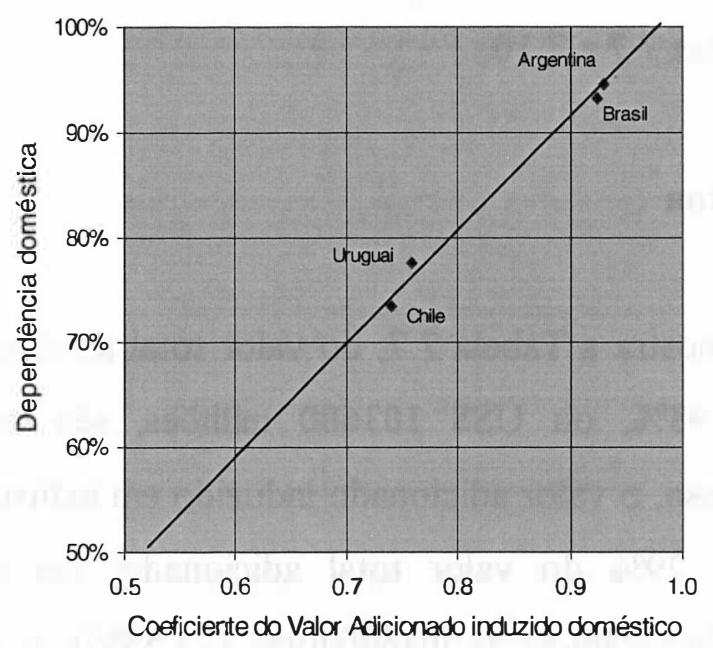

Figura 7.10 . Dependência doméstica versus coeficiente do valor adicionado induzido doméstico.

Como a "linha média de dispersão" está positivamente inclinada, pode-se concluir que: a) quanto mais alto for o coeficiente doméstico do país, mais alta é a proporção de dependência doméstica; b) os países com elevados coeficientes de valor adicionado induzido e de dependência doméstica (Argentina e Brasil) apresentam maiores possibilidades de incrementar o nível do valor adicionado em suas economias pela intensificação de seus fluxos de exportações.

\subsubsection{Valor adicionado setorial induzido pelas demandas finais e pelas exportações para o resto do mundo de cada país}

Analisaram-se, anteriormente, os efeitos da demanda final sobre o valor adicionado induzido, bem como suas características, através de seu respectivo coeficiente. Ressalva-se, contudo, que essa análise foi feita em termos agregados, restando saber, então, quais são os principais setores que processam tais efeitos nas economias. Assim, nesta seção, utilizando a equação (7.5), tem-se como propósito principal fazer uma análise desagregada do valor adicionado induzido. Para isso, as 
indústrias foram desagregadas em oito grandes setores, sendo os resultados dos cálculos apresentados nas Tabelas 7.7 a 7.10.

\section{Argentina}

Como mostra a Tabela 7.7, do valor total adicionado da Argentina (US\$ 111508 milhões), 92,98\%, ou US\$ 103680 milhões, são induzidos pela demanda doméstica final. Com isso, o valor adicionado induzido em indústrias, tais como serviços, é grande, totalizando $29 \%$ do valor total adicionado; em seguida, em ordem de importância relativa, destacam-se as manufaturas $(23,58 \%)$, o comércio $(20,60 \%)$ e a agropecuária $(9,58 \%)$.

Tabela 7.7 . Contribuição das demandas finais e das exportações para o resto do mundo no valor adicionado setorial induzido da Argentina, em milhões de dólares correntes de 1990.

\begin{tabular}{lrrrrrr}
\hline Setores & Argentina & Brasil & Chile & Uruguai & $\begin{array}{r}\text { Resto do. } \\
\text { mundo }\end{array}$ & Total \\
\hline 1 Agropecuária & 6971 & 479 & 48 & 19 & 3165 & 10682 \\
2 Extração mineral & 6036 & 43 & 31 & 27 & 412 & 6549 \\
3 Manufaturas & 23748 & 277 & 131 & 88 & 2048 & 26291 \\
4 Serviço ind. público & 3120 & 9 & 4 & 2 & 85 & 3220 \\
5 Construção civil & 5033 & 0 & 0 & 0 & 0 & 5033 \\
6 Comércio & 22968 & 0 & 0 & 0 & 0 & 22968 \\
7 Transporte & 2986 & 17 & 5 & 3 & 503 & 3514 \\
8 Serviços & 32818 & 43 & 18 & 12 & 359 & 33250 \\
\hline Total & 103680 & 868 & 237 & 152 & 6571 & 111508 \\
\hline
\end{tabular}

Nesse contexto, nota-se que as exportações para o resto do mundo em relação à região têm contribuído significativamente para a criação de valor adicionado. Isso ocorre porque as exportações de produtos agropecuários e de produtos manufaturados para o resto do mundo seguem a conta de US\$ 3165 milhões $(2,84 \%)$ e US\$ 2048 milhões $(1,84 \%)$ do total de valor adicionado induzido (US\$ 111508 milhões), 
o que equivale a dizer, respectivamente, $48,17 \%$ e $31,17 \%$ de valor adicionado gerado pelo total de exportações para o resto do mundo (US\$ 6571 milhões).

$\mathrm{Na}$ região, como se esperava, as ligações da Argentina com as economias do Mercosul são bem fracas, sendo o Brasil o parceiro que induz maior valor adicionado em sua economia. Note-se, entretanto, que a estrutura de contribuições inter-regionais se assemelha à do resto do mundo

Em geral, o valor adicionado induzido pelas demandas estrangeiras é importante para as indústrias agropecuárias da Argentina, bem como para as manufatureiras. Entretanto, uma análise ainda mais desagregada, com base na Tabela A2.3 do Apêndice 2, focalizando as indústrias com maior quantidade de valor adicionado induzido, indica que a maior parte do valor adicionado concentra-se em torno de produtos primários de simples processamento.

\section{Brasil}

De acordo com a Tabela 7.8, mais de $92 \%$ (US\$ 397515 milhões) do valor total adicionado no Brasil é induzido por demandas finais domésticas; em consequiência, a dependência de demandas estrangeiras é extremamente baixa (8\%). As indústrias primárias, todavia, contam com pouco mais de $10 \%$ do valor adicionado total induzido, o que significa que essa proporção tem um peso relativamente pequeno na economia brasileira se comparada com a dependência de exportações da Argentina, que oscila em torno de $16 \%$.

Os montantes mais elevados do valor adicionado induzido por demandas estrangeiras se concentram, basicamente, no setor manufatureiro, ainda que o tamanho dessas proporções varie de país para país. Assim, do total de valor adicionado induzido que gera a Argentina no Brasil (US\$ 1436 milhões), o setor manufatureiro conta com 65,74\% (US\$ 944 milhões). Tais proporções, no Chile, são de 70,35\% (US\$ 401 milhões); no Uruguai, de $67.28 \%$ (US\$ 183 milhões) e, no resto do mundo, somente de $48,75 \%$ (US\$ 14819 milhões). 
Tabela 7.8 . Contribuição das demandas finais e das exportações para o resto do mundo no valor adicionado setorial induzido do Brasil, em milhões de dólares correntes de 1990.

\begin{tabular}{lrrrrrr}
\hline Setores & Argentina & Brasil & Chile & Uruguai & $\begin{array}{r}\text { Resto do } \\
\text { mundo }\end{array}$ & Total \\
\hline 1 Agropecuária & 104 & 30996 & 27 & 23 & 3109 & 34259 \\
2 Extração mineral & 100 & 9551 & 28 & 12 & 2220 & 11910 \\
3 Manufaturas & 944 & 90470 & 401 & 183 & 14819 & 106818 \\
4 Serviço ind. público & 45 & 10946 & 18 & 8 & 837 & 11854 \\
5 Construção civil & 5 & 38516 & 2 & 1 & 123 & 38647 \\
6 Comércio & 79 & 43710 & 32 & 15 & 2293 & 46130 \\
7 Transporte & 47 & 14494 & 19 & 9 & 3313 & 17881 \\
8 Serviços & 112 & 158832 & 43 & 20 & 3686 & 162693 \\
\hline Total & 1436 & 397515 & 570 & 272 & 30400 & 430193 \\
\hline
\end{tabular}

No setor manufaturas, com base na Tabela A2.3 do Apêndice 2, as indústrias com um grau relativamente alto de dependência externa são refino de petróleo, mecânica, material de transporte, beneficiamento de vegetais, indústria têxtil e química farmacêutica e perfumaria.

\section{Chile}

Como fica claro na Tabela 7.9, em torno de 74\% (US\$ 13226 milhões) do total do valor adicionado do Chile (US\$ 17866 milhões) são induridos pela demanda final doméstica, isto é, a dependência por exportações é elevada já que corresponde, aproximadamente, a $26 \%$ (US\$ 4640 milhões) do total de seu valor adicionado induzido.

$\mathrm{Na}$ estrutura do valor adicionado induzido que depende da demanda final doméstica, o setor de extração mineral apresenta a menor dependência doméstica ( $20,81 \%$ ou US\$ 465 milhões); em oposição, no setor de manufaturas, pouco mais de três quartos (US\$ 2074 milhões) do valor adicionado dependem da demanda doméstica. Note-se que o grau de dependência doméstica do setor de mineração, associado às contribuições do resto do mundo no mesmo setor ( $37,86 \%$ ou US\$ 1635 milhões do total de valor adicionado induzido por exportações para o resto do mundo, US\$4319 milhões) 
e à produção induzida doméstica da Figura 7.2, deixa em evidência novamente que, na economia chilena, existe um alto grau de especialização nas atividades de mineração.

Tabela 7.9 . Contribuição das demandas finais e das exportações para o resto do mundo no valor adicionado induzido setorial do Chile, em milhões de dólares correntes de 1990.

\begin{tabular}{lrrrrrr}
\hline Setores & Argentina & Brasil & Chile & Uruguai & $\begin{array}{r}\text { Resto do } \\
\text { mundo }\end{array}$ & Total \\
\hline 1 Agropecuária & 14 & 20 & 1215 & 1 & 476 & 1726 \\
2 Extração mineral & 33 & 99 & 465 & 3 & 1635 & 2234 \\
3 Manufaturas & 36 & 30 & 2074 & 4 & 557 & 2702 \\
4 Serviço ind. público & 4 & 9 & 387 & 0 & 155 & 555 \\
5 Construção civil & 1 & 2 & 1040 & 0 & 35 & 1079 \\
6 Comércio & 7 & 14 & 2248 & 1 & 499 & 2768 \\
7 Transporte & 6 & 10 & 732 & 1 & 432 & 1180 \\
8 Serviços & 8 & 17 & 5066 & 1 & 530 & 5622 \\
\hline Total & 109 & 201 & 13226 & 11 & 4319 & 17866 \\
\hline
\end{tabular}

Por sua vez, o conjunto de exportações do Chile para os países parceiros é de $1,80 \%$ (US $\$ 4640$ milhões) do valor adicionado total induzido (US\$ 17866 milhões), o que significa que suas ligações na região são fracas. Nessa perspectiva, os setores de mineração, manufaturas e agropecuária são os que mais se destacam e, dentre eles, com base na Tabela A2.3 do Apêndice 2, as indústrias mais relevantes na geração de valor adicionado são as de produtos alimentares, serviços industriais públicos, papel celulose e gráfica, petróleo e gás e de plástico.

\section{Uruguai}

De acordo com a Tabela 7.10, à semelhança do Chile, o Uruguai apresenta uma dependência doméstica de 75,86\% (US\$ 3863 milhões). A participação do setor agropecuário, entretanto, é de $15,34 \%$ (US\$781 milhões) do valor adicionado total induzido (US\$5092 milhões), o que indica um peso elevado e semelhante ao da Argentina. 
O setor manufaturas do Uruguai apresenta uma participação de $28,16 \%$ (US\$ 1434 milhões) no total do valor adicionado induzido. A característica mais marcante nesse setor é que as indústrias são típicas processadoras de matérias-primas de origem agropecuária (Tabela A2.3 do Apêndice 2). Nota-se, ainda, que 34,02\% (US\$164 milhões) do total de exportações do setor (US\$1434 milhões) são destinadas ao Brasil e à Argentina, ou seja, grande parte das atividades de processamento do Uruguai depende das demandas do Brasil e da Argentina.

Tabela 7.10 . Contribuição das demandas finais e das exportações para o resto do mundo no valor adicionado setorial induzido do Uruguai, em milhões de dólares correntes de 1990.

\begin{tabular}{lrrrrrr}
\hline Setores & Argentina & Brasil & Chile & Uruguai & $\begin{array}{r}\text { Resto do } \\
\text { mundo }\end{array}$ & $\begin{array}{r}\text { Total } \\
\hline \text { 1 Agropecuária }\end{array}$ \\
2 Extração mineral & 18 & 91 & 4 & 462 & 205 & 781 \\
3 Manufaturas & 2 & 2 & 0 & 89 & 5 & 98 \\
4 Serviço ind. público & 56 & 108 & 7 & 953 & 311 & 1434 \\
5 Construção civil & 2 & 4 & 0 & 167 & 15 & 189 \\
6 Comércio & 1 & 1 & 0 & 242 & 5 & 249 \\
7 Transporte & 19 & 39 & 2 & 385 & 102 & 546 \\
8 Serviços & 6 & 10 & 1 & 202 & 56 & 275 \\
\hline Total & 12 & 18 & 1 & 1362 & 126 & 1519 \\
\hline
\end{tabular}

Enfim, a participação do setor primário (agropecuário e extração mineral) sobre o total de valor adicionado de cada país sintetiza a natureza do valor adicionado induzido no Mercosul, já que dele emergem dois padrões de comportamento diferenciados: um grupo com uma participação elevada (Chile, 22,17\%; Uruguai, 17,26\% e Argentina, 15,4\%) e outro com uma participação relativa pequena (Brasil, 10,7\%). Portanto, fica evidente, na geração de valor adicionado, que a importância relativa de atividades de produção primária é mais relevante no primeiro grupo de países, até porque os níveis de articulação ou industrialização de suas economias (Figura 6.3) são bem menos desenvolvidos que os do segundo grupo. 


\subsection{Demanda final e comércio externo}

Os itens das seção anterior destacaram, em relação ao valor adicionado induzido pelas demandas finais, que, nos próximos anos, o Chile e o Uruguai aumentarão sua dependência externa bem mais que a Argentina e o Brasil. Contudo, nesse processo, os fluxos de comércio industrial na região tenderão a especializar-se: nas exportações brasileiras, predominaram produtos acabados de matérias básicas industriais e bens de capital; nas exportações do Chile e do Uruguai e, em menor grau, da Argentina, predominaram produtos primários de simples processamento.

Em virtude desses prováveis aumentos de interdependência setorial na região, esta seção tem por objetivo identificar e avaliar as importações e exportações inter-regionais induzidas pelos diferentes componentes da demanda final de cada paísmembro do Mercosul.

\subsubsection{Importações agregadas induzidas pelas demandas finais de cada país}

Para obter a quantidade de importações intermediárias induzidas pelas demandas finais de cada país, deve-se considerar a identidade básica do modelo insumoproduto:

$$
X=A X+F+E
$$

onde:

$X$ é o valor da produção dos quatro países;

$A$ é a matriz de coeficientes técnicos dos quatro países;

$F$ é a matriz de demanda final dos quatro países e

$E$ representa as exportações para o resto do mundo. 
Resolvendo a equação (7.8) em relação a $X$, obtém-se

$$
X=(I-A)^{-1}(F+E)
$$

Em seqüência, subtraindo os blocos de transações domésticas da matriz de coeficientes técnicos $(A)$, ou seja, os blocos que constituem a diagonal principal da matriz $A$, obtém-se a matriz de coeficientes de importação inter-regional $\left(A^{m}\right)$. Assim, a quantidade de importação induzida em cada indústria dos países $\left(M^{*}\right)$ será

$$
M^{*}=A^{m} X
$$

Também pode ser definida da seguinte maneira:

$$
M^{*}=A^{m}(I-A)^{-1}(F+E)
$$

A Tabela 7.11 dá uma visão geral das quantidades de importações induzidas pelas demandas finais de cada país. As colunas mostram quanto de importações a demanda final de um dado país gerou em cada um dos seus parceiros. As linhas indicam a quantidade de importações de um país que foram induzidas pelas demandas finais de cada país parceiro, ou seja, as exportações induzidas.

Em termos relativos, a participação do total de importações induzidas sobre o total de importações intermediárias reais mostra que as demandas domésticas finais com maior capacidade para indurir importações são as da Argentina $(92,1 \%)$ e do Brasil (85,6\%). Contrariamente, as demandas domésticas finais que menos importações induzem são as do Chile $(68,1 \%)$ e do Uruguai $(77,1 \%)$.

Essas características das demandas finais no Mercosul mostram, contudo, padrões de influência diferentes. As proporções de importações inter-regionais induzidas, no total de importações intermediárias reais para 1990, indicam que as economias da Argentina (30,47\%), do Uruguai $(26,46 \%)$ e do Chile $(13,67 \%)$ apresentam, em relação 
ao Brasil (4,56\%), maior capacidade relativa para induzir importações no Mercosul. Entretanto, essa particularidade não deve ser interpretada como se as transações do Brasil "dentro" do Mercosul fossem pouco importantes; ao contrário, para seus países parceiros, são da maior relevância já que, do total de importações inter-regionais induzidas (US\$ 3315 milhões), pouco mais de 33\% (US\$ 1095 milhões) correspondem à influência da demanda final brasileira. Na verdade, a baixa participação inter-regional do Brasil nas importações induzidas simplesmente está indicando que sua capacidade de induzir importações está canalizada, em sua maior parte, para o resto do mundo (US\$ 2852 milhões).

Tabela 7.11 . Valor das importações intermediárias induzidas pela demanda final de cada país do Mercosul (em milhões de dolares de 1990).

Argentina Brasil Chile Uruguai Total

\begin{tabular}{lrrrrr}
\hline Argentina & 0 & 709 & 167 & 96 & 972 \\
Brasil & 1232 & 0 & 349 & 161 & 1742 \\
Chile & 114 & 226 & 0 & 11 & 351 \\
Uruguai & 78 & 160 & 14 & 0 & 252 \\
\hline Total importações inter-regionais & 1424 & 1095 & 530 & 269 & 3316 \\
\hline Frete e seguro internacional & 27 & 23 & 13 & 7 & 70 \\
Importações do resto do mundo & 2852 & 19453 & 2098 & 505 & 24909 \\
Total importações domésticas induzidas & 4303 & 20570 & 2641 & 781 & 28225 \\
\hline Total importações intermediárias & 4673 & 24039 & 3878 & 1013 & 33603 \\
\hline Participação inter-regional (\%) & 30,5 & 4,6 & 13,7 & 26,5 & 9,9 \\
Participação doméstica (\%) & 92,1 & 85,6 & 68,1 & 77,1 & 84,0 \\
\hline
\end{tabular}

Os valores das estruturas inter-regionais induzidas da Tabela 7.11 permitem, por outro lado, que se estabeleça um balanço das influências das demandas de cada país na região como país indutor (coluna) e país induzido (linha). Em termos absolutos, a capacidade de induzir importações na região segue a seguinte ordem de importância: Argentina com US\$ 1424 milhões; Brasil com US\$ 1095 milhões; Chile com US\$ 530 milhões e Uruguai com US\$ 268 milhões. Por sua vez, a ordem dos países que foram mais induzidos é: Brasil com US\$ 1742 milhões; Argentina com US\$ 972 milhões; 
Chile com US\$ 351 milhões e Uruguai com US\$252 milhões. Nota-se, com isso, que o Brasil é o único dos quatro países que apresenta um saldo positivo em seu favor (US\$ 647 milhões). Esse fato em particular leva, em termos relativos, a afirmar que o Brasil, na região, apresenta uma maior capacidade para exportar do que para importar; o inverso é verdadeiro para a Argentina, o Chile e o Uruguai. Resta, portanto, avaliar e caracterizar tais processos.

\subsubsection{Coeficiente de importação induzida pela demanda final de cada país}

Com base nas Tabelas 7.4 (valores da demanda final) e 7.11, pode-se estabelecer também o coeficiente de importação induzida pela demanda final $\left(C M^{F r}\right)$ :

$$
C M^{F r}=M^{r s} / F^{s}
$$

isto é, a divisão das importações induzidas de um país $\left(M^{* r s}\right)$ pela respectiva demanda final de cada país $\left(F^{\circ}\right)$. Os resultados são apresentados na Tabela 7.12.

Tabela 7.12 . Coeficiente de importação induzida da demanda final para cada país.

Argentina Brasil Chile Uruguai Total

\begin{tabular}{llllll}
\hline Argentina & 0,0000 & 0,0017 & 0,0092 & 0,0193 & 0,0017 \\
Brasil & 0,0112 & 0,0000 & 0,0194 & 0,0324 & 0,0031 \\
Chile & 0,0010 & 0,0005 & 0,0000 & 0,0022 & 0,0006 \\
Uruguai & 0,0007 & 0,0004 & 0,0008 & 0,0000 & 0,0005 \\
\hline Frete e seguro internacional & 0,0002 & 0,0001 & 0,0007 & 0,0014 & 0,0001 \\
Importações do resto do mundo & 0,0260 & 0,0456 & 0,1164 & 0,1015 & 0,0446 \\
Total importações domésticas & 0,0393 & 0,0483 & 0,1465 & 0,1568 & 0,0505 \\
induzidas & & & & & \\
\hline Total importações intermediárias & 0,0426 & 0,0564 & 0,2151 & 0,2034 & 0,0601 \\
\hline Demanda final & 1,0000 & 1,0000 & 1,0000 & 1,0000 & 1,0000 \\
\hline
\end{tabular}

Os coeficientes de importações induzidas para Argentina e Brasil são 
0,0426 e 0,0564 , respectivamente, sendo consideravelmente mais baixos que os coeficientes para Chile $(0,2151)$ e Uruguai $(0,2034)$. Os pequenos coeficientes de importação argentinos e brasileiros, associados a seus respectivos coeficientes de produção doméstica induzida elevados (Tabela 7.2), indicam novamente que alterações em suas demandas finais não exercem muita influência sobre as importações, mas, sim, um grande impacto sobre as produções domésticas. Contudo, frente a essas características, parece razoável pensar que estímulos elevados nas importações, sem uma contrapartida, darão origem a sérios problemas para as indústrias domésticas, já que existirá uma redução na produção desses.

O Chile e o Uruguai, particularmente, mostram altos coeficientes de importação induzida. $\mathrm{O}$ coeficiente do Chile é pouco mais de cinco vezes o da Argentina e quase quatro vezes o do Brasil; por sua vez, o coeficiente do Uruguai é quase cinco vezes o da Argentina e um pouco mais que três vezes o do Brasil. Os elevados coeficientes do Chile e Uruguai, em parte, devem-se ao fato de as importações de bens de capital e de diversos materiais para o funcionamento de suas indústrias serem uma necessidade estrutural de suas economias. Essa necessidade, certamente, deve-se à imaturidade de suas indústrias. As Tabelas 7.13 e 7.14, que listam as principais importações que induzem esses países no Mercosul, tornam esse ponto claro. As estimativas foram estabelecidas a partir da equação (7.10), considerando-se, no entanto, 31 setores para cada país.

O Chile induz uma grande quantia de materiais industriais básicos, tais como produtos metalúrgicos, materiais têxteis, produtos químicos derivados do petróleo, material de transportes e mecânica. Por exemplo, as importações induzidas nos produtos metalúrgicos de transporte e têxteis brasileiros contam, respectivamente, com 19,9\%, $15,4 \%$ e $5,8 \%$ do total de importações inter-regionais induzidas. Do mesmo modo, a Argentina induz importações em produtos do petróleo, químicos básicos e têxteis, que participam com $5,5 \%, 3,3 \%$ e $1,8 \%$, respectivamente. 
Tabela 7.13 . Importações induzidas pela demanda final do Chile (acima de US\$ 10 milhões).

\begin{tabular}{|c|c|c|c|c|c|}
\hline Setores & Países e indústrias & $\begin{array}{r}\text { Importações } \\
\text { induzidas } \\
\text { (US\$ milhōes) }\end{array}$ & $\begin{array}{r}\text { Participação } \\
\text { percentual }\end{array}$ & $\begin{array}{l}\text { Percentual } \\
\text { acumulado }\end{array}$ & $\begin{array}{r}\text { Percentual } \\
\text { acumulado } \\
\text { do país }\end{array}$ \\
\hline & Argentina & & & & \\
\hline 1 & Agropecuária & 11 & $2,2 \%$ & $2,2 \%$ & \\
\hline 13 & Química Básica & 18 & $3,3 \%$ & $5,5 \%$ & \\
\hline 14 & Refino do Petróleo & 29 & $5,5 \%$ & $11,0 \%$ & \\
\hline 17 & Indústria Têxtil & 10 & $1,8 \%$ & $12,8 \%$ & \\
\hline 23 & Fab. e Refino de Açúcar & 11 & $2,0 \%$ & $14,7 \%$ & \\
\hline 24 & Fab. Óleo Vegetal e Animal & 34 & $6,4 \%$ & $21,1 \%$ & $21,1 \%$ \\
\hline & Brasil & & & & \\
\hline 36 & Ind. Metalúrgica Básica & 106 & $19,9 \%$ & $41,0 \%$ & \\
\hline 37 & Mecânica & 12 & $2,2 \%$ & $43,2 \%$ & \\
\hline 40 & Material de Transporte & 82 & $15,4 \%$ & $58,6 \%$ & \\
\hline 42 & Papel, Celulose e Gráfica & 19 & $3,7 \%$ & $62,3 \%$ & \\
\hline 45 & Refino do Petróleo & 16 & $3,1 \%$ & $65,4 \%$ & \\
\hline 46 & Químicos, Farmácia e Perf. & 14 & $2,6 \%$ & $67,9 \%$ & \\
\hline 48 & Indústria Têxtil & 31 & $5,8 \%$ & $73,8 \%$ & $52,7 \%$ \\
\hline \multicolumn{2}{|c|}{ Total importação inter-regional induzida } & 532 & $100,0 \%$ & & $73,8 \%$ \\
\hline
\end{tabular}

Tabela 7.14 . Importações induzidas pela demanda final do Uruguai (acima de US\$ 5 milhões).

\begin{tabular}{|c|c|c|c|c|c|}
\hline Setores & Países e indústrias & $\begin{array}{r}\text { Importações } \\
\text { induzidas } \\
\text { (US\$ milhöes) }\end{array}$ & $\begin{array}{r}\text { Participação } \\
\text { percentua }\end{array}$ & $\begin{array}{l}\text { Percentual } \\
\text { acumulado }\end{array}$ & $\begin{array}{r}\text { Percentual } \\
\text { acumulado } \\
\text { do país }\end{array}$ \\
\hline & Argentina & & & & \\
\hline 1 & Agropecuária & 7 & $2,8 \%$ & $2,8 \%$ & \\
\hline 9 & Material de Transporte & 7 & $2,8 \%$ & $5,5 \%$ & \\
\hline 13 & Química Básica & 10 & $3,8 \%$ & $9,3 \%$ & \\
\hline 14 & Refino do Petróleo & 21 & $7,9 \%$ & $17,2 \%$ & \\
\hline 15 & Químicos, Farmácia e Perfumaria & 14 & $5,2 \%$ & $22,4 \%$ & \\
\hline 17 & Indústria Têxtil & 5 & $2,0 \%$ & $24,4 \%$ & \\
\hline 19 & Indústria do Couro & 6 & $2,3 \%$ & $26,7 \%$ & $26,7 \%$ \\
\hline & Brasil & & & & \\
\hline 32 & Agropecuária & 5 & $1,8 \%$ & $28,5 \%$ & \\
\hline 33 & Extração Mineral & 6 & $2,1 \%$ & $30,6 \%$ & \\
\hline 36 & Ind. Metalúgica Básica & 47 & $17,6 \%$ & $48,2 \%$ & \\
\hline 37 & Mecânica & 5 & $1,8 \%$ & $50,0 \%$ & \\
\hline 38 & Material Elétrico & 6 & $2,1 \%$ & $52,1 \%$ & \\
\hline 40 & Material de Transporte & 33 & $12,1 \%$ & $64,2 \%$ & \\
\hline 42 & Papel, Celulose e Gráfica & 12 & $4,5 \%$ & $68,8 \%$ & \\
\hline 46 & Químicos, Farmácia e Perfumaria & 16 & $5,8 \%$ & $74,5 \%$ & \\
\hline 48 & Indústria Têxtil & 9 & $3,4 \%$ & $77,9 \%$ & $51,2 \%$ \\
\hline \multicolumn{2}{|c|}{ Total importação inter-regional induzida } & 269 & $100,0 \%$ & & $77,9 \%$ \\
\hline
\end{tabular}

A economia chilena também induz na Argentina importações de produtos agropecuários (grãos e carnes vermelhas) e alimentos processados de consumo humano e 
animal. Dentre estes, destacam-se as importações reduzidas de óleo vegetal e animal e de açúcar, que contam, respectivamente, com $6,4 \%$ e $2 \%$ do total de importações interregionais induzidas.

Em resumo, pode-se afirmar que o Chile induz importações consideráveis de materiais industriais básicos e, em menor grau, de produtos alimentícios. Essa característica, por outro lado, associada ao percentual acumulado da Argentina $(21,1 \%)$ e do Brasil (52,7\%), indica que a economia brasileira, num processo de maior interdependência comercial, será um grande fornecedor de bens de capital e materiais industriais básicos para o Chile.

O Uruguai, em relação ao Chile, induz importações num número maior de setores, as quais, entretanto, se concentram principalmente em materiais industriais básicos e em bens de capital de origem brasileira e argentina. Por exemplo, a participação das importações induzidas na metalúrgica básica, nos materiais de transporte, produtos químicos e farmacêuticos, produtos de celulose e têxteis do Brasil, conta, respectivamente, com $17,6 \%, 12,1 \%, 5,8 \%, 4,5 \%$ e $3,4 \%$ do total de importações induzidas na região. $\mathrm{Na}$ Argentina, os que mais se destacam são refino do petróleo, produtos químicos e farmacêuticos, química básica, materiais de transporte e extração mineral, com $7,9 \%, 5,2 \%, 3,8 \%, 2,8 \%$ e $2,1 \%$, respectivamente.

A economia uruguaia também induz na Argentina e no Brasil importações de produtos agropecuários (grãos, extração vegetal, silvicultura). Contudo, dado que, no conjunto, só representam 4,6\% dos $77,9 \%$ de importações induzidas acumuladas, essas parecem não ser muito relevantes. Nota-se ainda, de acordo com o percentual acumulado em cada país, que o Brasil (51,2\%) novamente aparece como sendo um grande fornecedor de bens de capital e de materiais industriais básicos.

\subsubsection{Exportações induzidas pelas demandas finais de cada país}

De acordo com a estrutura da matriz insumo-produto do Mercosul, as importações que cada país induz são as exportações dos países parceiros. Para os países 
exportadores, os fluxos de comércio geram atividades de produção doméstica, bem como de valor adicionado. Contudo, em função dos multiplicadores setoriais, o efeito total de uma unidade adicional de exportações na economia não se obtém numa primeira etapa, mas num conjunto de etapas contínuas até que a demanda e o suprimento estejam equilibrados. Desse modo, quando é modificada a demanda final em um país, surgirá um processo que traz efeitos de repercussão na produção e no mercado com os países com os quais aquele mantém relações comerciais. Assim, dado que, na seção anterior, foram examinadas as importações induridas pelas demandas finais, nesta seção, será examinado quanto de exportações induzidas são geradas pelas demandas finais dos países parceiros.

Com base na Tabela 7.15, dentre as exportações agregadas induzidas pelas demandas finais, fica notório que a Argentina e o Brasil têm uma participação elevada no Mercosul. Isso ocorre porque grande parte dos fluxos de exportação dos países parceiros têm como destino a Argentina (42,7\%) e o Brasil (32,5\%), os quais, somados, ascendem a $76,2 \%$ do total de exportações induzidas na região. Em contraste, a parte combinada do Chile $(15,8 \%)$ e Uruguai $(8,0 \%)$ é somente de $23,8 \%$.

Tabela 7.15: Exportações induzidas pela demanda final de cada país no Mercosul.

\begin{tabular}{lrrrrr}
\hline & Argentina & Brasil & Chile & Uruguai & Total \\
& & & & & \\
\hline Argentina & $1,3 \%$ & $72,0 \%$ & $16,9 \%$ & $9,8 \%$ & $100,0 \%$ \\
Brasil & $69,4 \%$ & $1,9 \%$ & $19,6 \%$ & $9,1 \%$ & $100,0 \%$ \\
Chile & $32,2 \%$ & $64,0 \%$ & $0,6 \%$ & $3,2 \%$ & $100,0 \%$ \\
Uruguai & $31,0 \%$ & $63,3 \%$ & $5,6 \%$ & $0,2 \%$ & $100,0 \%$ \\
\hline Total & $42,7 \%$ & $33,5 \%$ & $15,8 \%$ & $8,0 \%$ & $100,0 \%$ \\
\hline
\end{tabular}

A estrutura por origem e destino das exportações assinala, na economia chilena, que $64 \%$ de suas exportações são induzidas pelo Brasil; 32,2\%, pela Argentina e somente $3,2 \%$, pelo Uruguai. No caso da economia uruguaia, a estrutura de suas exportações apresenta-se bastante semelhante: 63,3\% correspondem ao Brasil; $31 \%$, à Argentina e 5,6\%, ao Chile. Já as exportações induzidas da Argentina e do Brasil 
mostram uma estrutura mais concentrada: na Argentina, $72 \%$ de suas exportações são induzidas pelo Brasil; 16,9\%, pelo Chile e 9,8\%, pelo Uruguai; no Brasil, por sua vez, $69,4 \%$ de suas exportações são induzidas pela Argentina; 19,6\%, pelo Chile e 9,1\%, pelo Uruguai. Em síntese, pode-se afirmar que: a) os fluxos de exportações dos países do Mercosul são dinamizados em sua maior parte pelas economias da Argentina e do Brasil; b) as exportações que a Argentina e o Brasil mutuamente se induzem representam pouco mais de $57 \%$ do total de importações, o que os constitui, nas estruturas de transações, como os maiores parceiros.

Nesse contexto, a partir da equação (7.10), uma análise mais desagregada das exportações induzidas pelas demandas finais de cada país permite identificar, em nível de indústrias, os fluxos de comércio mais importantes do Mercosul. Assim, dentre os resultados desses cálculos, são apresentadas nas Tabelas 7.16 a 7.19 as dez maiores indústrias de cada país.

\section{Argentina}

Mencionou-se anteriormente que, no Mercosul, as indústrias da Argentina têm fortes ligações com as do Brasil. A isso deve-se mencionar, após uma análise mais detalhada das dez maiores indústrias da Argentina (Tabela 7.16), que tais ligações se processam principalmente através de produtos agropecuários, material de transporte, química básica, couro, óleo vegetal e animal, mecânica e produtos de farmácia e perfumaria. Nota-se, com isso, que, dos dez maiores itens que contam com $72,4 \%$ das exportações induzidas totais, sete são induzidos pelas demandas finais do Brasil, dentre os quais o primeiro item, exportações agropecuárias, conta com $42,5 \%$ do total de exportações induzidas.

As demandas finais de Uruguai e Chile exercem menos influência sobre a economia argentina. Entretanto, o Uruguai se destaca por induzir exportações nas indústrias de refino de petróleo e o Chile, além das do refino de petróleo, também nas indústrias de óleo vegetal e animal. 
Tabela 7.16 . Exportações inter-regionais induzidas das dez maiores indústrias da Argentina.

\begin{tabular}{rlrrrr}
\hline Ordem & $\begin{array}{l}\text { Demanda } \\
\text { final dos } \\
\text { países }\end{array}$ & $\begin{array}{l}\text { Indústrias da Argentina } \\
\text { com exportações } \\
\text { induzidas }\end{array}$ & $\begin{array}{r}\text { Total exportação } \\
\text { induzida } \\
\text { (US } \$ \text { milhões) }\end{array}$ & $\begin{array}{r}\text { Contribuição } \\
\text { acumulada } \\
\text { (US } \$ \text { milhões) }\end{array}$ & $\begin{array}{r}\text { Contribuição } \\
\text { percentual } \\
\text { acumulada }\end{array}$ \\
\hline 1 & Brasil & Agropecuária & 418 & 418 & $42,5 \%$ \\
2 & Brasil & Material de transporte & 58 & 476 & $48,3 \%$ \\
3 & Brasil & Química básica & 48 & 524 & $53,2 \%$ \\
4 & Chile & Fab. óleo veg. e Animal & 34 & 558 & $56,7 \%$ \\
5 & Brasil & Indústria do couro & 33 & 591. & $60,0 \%$ \\
6 & Brasil & Fab. óleo veg. e animal & 32 & 623 & $63,2 \%$ \\
7 & Chile & Refino do petróleo & 29 & 652 & $66,2 \%$ \\
8 & Uruguai & Refino do petróleo & 21 & 673 & $68,4 \%$ \\
9 & Brasil & Mecânica & 20 & 693 & $70,4 \%$ \\
10 & Brasil & Químicos, farmácia perf. & 20 & 713 & $72,4 \%$ \\
\hline
\end{tabular}

Tabela 7.17 . Exportações inter-regionais induzidas das dez maiores indústrias do Brasil.

\begin{tabular}{rllrrr}
\hline Ordem & $\begin{array}{l}\text { Demanda } \\
\text { final dos } \\
\text { países }\end{array}$ & $\begin{array}{l}\text { Indústriasdo Brasil } \\
\text { com exportações }\end{array}$ & $\begin{array}{r}\text { Total exportação } \\
\text { induzidas }\end{array}$ & $\begin{array}{r}\text { Contribuição Contribuição } \\
\text { acumulada } \\
\text { (US\$ milhões) }\end{array}$ & $\begin{array}{r}\text { percentual } \\
\text { as } \$ \text { milhões) }\end{array}$ \\
\hline 1 & Argentina & Material de transporte & 372 & 372 & $21,0 \%$ \\
2 & Argentina & Ind. metalúrgica básica & 233 & 606 & $34,1 \%$ \\
3 & Chile & Ind. metalúrgica básica & 106 & 711 & $40,1 \%$ \\
4 & Chile & Material de transporte & 82 & 793 & $44,7 \%$ \\
5 & Argentina & Extração mineral & 81 & 874 & $49,2 \%$ \\
6 & Argentina & Papel, celulose e Gráf. & 80 & 954 & $53,7 \%$ \\
7 & Argentina & Indústria têxtil & 60 & 1014 & $57,1 \%$ \\
8 & Argentina & Mecânica & 58 & 1072 & $60,4 \%$ \\
9 & Argentina Material elétrico & 58 & 1130 & $63,6 \%$ \\
10 & Argentina & Quimica Básica & 57 & 1187 & $66,8 \%$ \\
\hline
\end{tabular}

\section{Brasil}

As indústrias de exportação brasileiras mais afetadas pelas demandas finais dos países parceiros (Tabela 7.17) incluem, fundamentalmente, bens de capital e materiais industriais básicos, tais como material de transporte, produtos metalúrgicos, extração mineral, produtos derivados da celulose, têxteis, mecânica, material elétrico e produtos químicos básicos. A Argentina e o Chile, no entanto, conjuntamente, contam com $66,8 \%$ das transações inter-regionais do Brasil, estando as ligações industriais predominantemente concentradas com as indústrias argentinas $(56,2 \%)$. 
Tabela 7.18 . Exportações inter-regionais induzidas das dez maiores indústrias do Chile.

\begin{tabular}{cllrrr}
\hline Ordem & $\begin{array}{l}\text { Demanda } \\
\text { final dos } \\
\text { países }\end{array}$ & $\begin{array}{l}\text { Indústrias do Chile } \\
\text { com exportações } \\
\text { induzidas }\end{array}$ & $\begin{array}{r}\text { Total exportação } \\
\text { induzida } \\
\text { (US\$ milhões) }\end{array}$ & $\begin{array}{r}\text { Contribuição } \\
\text { acumulada } \\
\text { (US \$milhões) }\end{array}$ & $\begin{array}{r}\text { Contribuição } \\
\text { percentual } \\
\text { acumulada }\end{array}$ \\
\hline 1 & Brasil & Extração mineral & 156 & 156 & $44,3 \%$ \\
2 & Argentina & Extração mineral & 45 & 201 & $57,0 \%$ \\
3 & Argentina & Papel, celulose, gráf. & 26 & 227 & $64,3 \%$ \\
4 & Brasil & Papel, celulose, gráf. & 21 & 248 & $70,3 \%$ \\
5 & Brasil & Agropecuária & 19 & 267 & $75,8 \%$ \\
6 & Argentina & Ind metalúrgica básica & 19 & 287 & $81,3 \%$ \\
7 & Brasil & Outros alimentares & 9 & 295 & $83,8 \%$ \\
8 & Argentina & Agropecuária & 8 & 304 & $86,1 \%$ \\
9 & Uruguai & Extração mineral & 4 & 307 & $87,1 \%$ \\
10 & Argentina & Outros alimentares & 4 & 311 & $88,2 \%$ \\
\hline
\end{tabular}

Tabela 7.19 . Exportações inter-regionais induzidas das dez maiores indústrias do Uruguai.

\begin{tabular}{cllrrr}
\hline Ordem & $\begin{array}{l}\text { Demanda } \\
\text { final dos } \\
\text { países }\end{array}$ & $\begin{array}{l}\text { Indústria do Uruguai } \\
\text { com exportações } \\
\text { induzidas }\end{array}$ & $\begin{array}{r}\text { Total exportação } \\
\text { induzida } \\
\text { (US } \$ \text { milhões) }\end{array}$ & $\begin{array}{r}\text { Contribuição } \\
\text { acumulada } \\
\text { (US\$milhões) }\end{array}$ & $\begin{array}{r}\text { Contribuição } \\
\text { percentual } \\
\text { acumulada }\end{array}$ \\
\hline 1 & Brasil & Agropecuária & 68 & 68 & $27,1 \%$ \\
2 & Brasil & Quimicos, farmacia perf & 16 & 84 & $33,4 \%$ \\
3 & Argentina & Papel, celulose e gráf. & 14 & 98 & $39,0 \%$ \\
4 & Argentina & Material de transporte & 13 & 111 & $44,1 \%$ \\
5 & Brasil & Ind. têxtil & 13 & 125 & $49,4 \%$ \\
6 & Brasil & Benef. de vegetais. & 12 & 136 & $54,1 \%$ \\
7 & Argentina & Indústria têxtil & 11 & 148 & $58,4 \%$ \\
8 & Brasil & Refino do petróleo & 10 & 158 & $62,4 \%$ \\
9 & Brasil & Abate de animais & 10 & 167 & $66,2 \%$ \\
10 & Argentina & Químicos, farmácia perf & 9 & 176 & $69,7 \%$ \\
\hline
\end{tabular}

Embora a influência da demanda final uruguaia não apareça entre as dez maiores indústrias, cabe salientar que as exportações que este país induz no Brasil coincidem com os itens nos quais as demandas finais da Argentina e do Chile induzem exportações. Esse fato confirma, definitivamente, que o Brasil é um grande fornecedor de materiais para o funcionamento das indústrias de seus países parceiros.

\section{Chile}

Com base na Tabela 7.18, observa-se que as dez maiores indústrias são induzidas pelas demandas finais do Brasil, Argentina e Uruguai, as quais participam com 
$88.2 \%$ do total das exportações inter-regionais induzidas. Em particular, destacam-se os dois primeiros itens, exportações induzidas de extração mineral pelo Brasil e Argentina, que participam com $57 \%$ do total de exportações induzidas. Isso demonstra que as exportações induzidas estão concentradas em atividades de mineração.

Nota-se ainda que, além das indústrias de papel, celulose e gráfica e metálica básica, as exportações das indústrias agropecuárias e outros alimentos, tais como frutas in natura, produtos pesqueiros preparados para consumo humano e animal e bebidas alcoólicas, também são relevantes para a economia chilena. Com isso, fica evidente que as principais exportações induzidas do Chile se desenvolvem em torno da mineração e de produtos agropecuários processados.

\section{Uruguai}

O Brasil e a Argentina induzem as exportações mais importantes da economia uruguaia (Tabela 7.19). No Uruguai, as atividades de exportação estão concentradas nas indústrias agropecuárias e nas de matérias-primas de simples processamento.

Nesse sentido, as demandas finais do Brasil induzem as exportações de produtos agropecuários, químicos, farmacêuticos e perfumaria, têxteis, beneficiamento vegetal, refino de petróleo e abate de animais, os quais, acumulados, participam com $51,2 \%$. Já a Argentina induz as exportações de produtos de papel, celulose e gráfica, material de transporte, têxteis e produtos químicos farmacêuticos e perfumaria, que participam com $18,5 \%$ do total de exportações induzidas.

Finalmente, algumas características gerais podem ser destacadas sobre as exportações inter-regionais induzidas no Mercosul: a) a importância relativa de setores primários de exportação é mais relevante em economias que apresentam indústrias menos articuladas, por exemplo: na Argentina e no Uruguai, destacam-se os setores da agropecuária e, no Chile, os setores de mineração; b) contrariamente a esse fato, na economia brasileira, que tem uma indústria melhor articulada, os setores de produção 
secundária de exportação, tais como material de transporte e metalúrgica básica, são os mais relevantes; c) contudo, essas características das exportações induzidas na região, associadas às características do valor adicionado induzido e à considerável diversidade de setores envolvidos na estrutura de transações inter-regionais, demonstram claramente que, num processo de intensificação comercial, os níveis de complementaridade econômica dos mercados "caminharão" por duas vertentes: nos fluxos de comércio dos setores de material de transporte e de metalúrgica do Brasil (Tabela 7.17) com os setores da agropecuária da Argentina e do Uruguai e, ainda, com o setor de mineração do Chile (Tabelas 7.16, 7.18 e 7.19), os quais apresentam maiores valores exportados, existirá uma tendência à especialização; entre os setores restantes, haverá uma diversificação ampla do comércio, até porque o intercâmbio comercial se processa entre setores primários e secundários da mais variada índole. 


\section{CONCLUSÕES}

Esta pesquisa, no contexto do Mercosul, tem como escopo o fornecimento de subsídios para que melhor se entendam as relações intersetoriạis estabelecidas com o comércio inter-regional entre países com gritantes desigualdades de desenvolvimento econômico nas estruturas de produção e consumo. Para isso, argumenta, com base na teoria econômica e em algumas características das economias da região, que a formação do novo mercado, produto do processo da integração econômica regional, poderia ser. dinamizada, fundamentalmente, pelas regiões-pólo de crescimento nacionais e, em decorrência, pelos países que detêm as indústrias melhor articuladas. Em conseqüência, as probabilidades de esses países induzirem a má distribuição dos custos e benefícios do comércio inter-regional são elevadas e vêm provocando as mais diversas reações, preocupações e esperanças sobre os seus efeitos na opinião pública, nos setores político, técnico e acadêmico.

Argumenta-se, ainda, que os órgãos executivos dos diversos esquemas de integração do continente, inclusive os do Mercosul, não contam com um instrumental analítico sistêmico em matéria de mensuração dos efeitos de encadeamento intersetorial entre os países; portanto, existem sérias limitações para a construção, implementação e coordenação de políticas macroeconômicas e setoriais bem-sucedidas. A análise dos fatos mais relevantes que apresenta a experiência de integração econômica do continente nos últimos 37 anos, em geral, leva a concluir-se que esses argumentos são válidos e de extrema importância. 
Considerando que as negociações do Mercosul vão muito além dos recentes acordos políticos de sua criação - já que o processo de integração econômica de seus países-membros data de 1960, quando participavam da Alalc, e, na atualidade, o Mercosul representa um subgrupo de integração na Aladi -, para a compreensão da proposta de integração econômica regional do passado, colocam-se duas questões básicas: a ênfase em acelerar a industrialização com base na tese de que, sem ela, o desenvolvimento econômico seria impossível e a condição de que os problemas básicos da industrialização na região estariam (e estão) atrelados às limitações dos mercados nacionais a que as indústrias estariam circunscritas. Daí, considerando que o primeiro impacto de um processo de integração econômica regional é o incremento da demanda, na época, a implementação de um processo integracionista era uma solução plausível e complementar às políticas industrializantes de cada país. A integração do passado apresentava-se, portanto, como uma condição para a industrialização, que, por sua vez, além de justificá-la, foi sua motivação mais importante.

Contudo, a partir da segunda metade da década de 1980, fica evidente, no processo de integração econômica do continente, uma nova dinâmica: o abandono do modelo de crescimento baseado na substituição de importações pela opção de um projeto de abertura liberal do mercado que compatibiliza acordos regionais com certo grau de protecionismo. A razão disso está em se acreditar que uma maior interdependência interregional permite obter melhores condições de inserção no processo de globalização da economia internacional e que, através dos excedentes do comércio inter-regional, na ausência de capital estrangeiro, pode-se financiar e promover o desenvolvimento economico regional, até porque, nos níveis atuais de globalização financeira, o investimento direto internacional é alocado em países, ou regiões que apresentam melhores atributos construidos. Portanto, a integração do presente representa para muitos setores de produção e consumo a troca do conforto propiciado por um mercado protecionista, pelos riscos e vantagens existentes numa economia de mercado aberto em nível regional, mas com um mínimo de proteção frente a terceiros países. 
A gritante heterogeneidade de desenvolvimento econômico na estrutura de produção e consumo que apresentam os países no processo de implementação da integração econômica tem sido a principal causa de discórdia e conflito no seio dos diversos esquemas de integração no continente. No entanto, mesmo sendo evidentes essas disparidades e os problemas que implicam, é comum perceber, de 1960 até hoje, uma acentuada insistência em integrar as economias dos países somente liberalizando o comércio inter-regional, acreditando-se, erroneamente, que as desigualdades econômicas serão superadas com o tratamento diferenciado do comércio em favor dos países que apresentam uma balança comercial deficitária. Dessa forma, fica evidente que os mecanismos de integração objetivam mais amenizar o sentido do comércio do que solucionar as disparidades regionais, até porque, para a implementação de outras políticas, são desconhecidos os impactos intersetoriais do comércio inter-regional. Portanto, torna-se claro o porquê da inexistência de uma autoridade supranacional atuante, que gerencie políticas setoriais e nacionais de redistribuição dos custos e beneficios.

Frente à necessidade de desenvolver um instrumento analítico intersetorial que considere a heterogeneidade econômica dos países do Mercosul, o arcabouço teórico e a implementação do quadro geral dos modelos insumo-produto revelam que os processos de interdependência comercial dos países podem ser abordados de forma sistêmica em termos de insumos e produtos. A análise insumo-produto considera o conjunto das economias como um só sistema em equilíbrio geral, no qual a economia é descrita em termos de fluxos e transferências de insumos e produtos de um setor a outro e, ainda, os produtos são considerados insumos na medida em que sejam aproveitáveis por outro sistema em cadeia. Entretanto, dado que o objetivo é tornar clara a estrutura de transações entre os setores dos países considerando suas desigualdades de desenvolvimento econômico, conclui-se que, dentre os diversos modelos existentes, o modelo insumo-produto internacional que apresenta delineamentos mais adequados para o Mercosul é o do tipo multilateral. 
Como as próprias estatísticas dos dados disponíveis determinam aspectos centrais da orientação do modelo insumo-produto internacional do Mercosul, em virtude da limitação das informações, a técnica alternativa usada para estimar os coeficientes técnicos de abastecimento internacional utiliza as matrizes de importações de cada país como fator de ponderação-linha, bem como a estrutura dos vetores de exportações por origem e destino. A partir desta técnica, a estrutura de demanda e oferta de cada país que faz parte do sistema caracteriza-se por ser diferente, além de preservar a parte real das economias e, sobretudo, a consistência contábil das estatísticas. Portanto, a técnica alternativa de coeficientes-linha utilizada marca também uma diferença fundamental em relação aos modelos clássicos de coeficiente-linha de Hansen e Teibout, nos quais as estruturas de demanda dos países são iguais. Daí a conclusão de que o modelo insumoproduto internacional do Mercosul construído para 1990 apresenta características próprias, sendo mais compatível com os pressupostos básicos da teoria clássica de equilíbrio geral.

O perfil das estruturas de transações internacionais insumo-produto do Mercosul em 1990 indica, em termos relativos, que a integração espacial dos mercados da Argentina e do Brasil e, em menor grau, do Chile e do Uruguai, com o mercado mundial é limitada, adquirindo características dramáticas quando relacionado ao Mercosul. Desse fato, depreende-se a artificialidade do processo de integração econômica do Mercosul, já que não é conseqüência natural de fluxos de comércio intensos, mas, sim, de um processo provocado em função da conjuntura econômica internacional, na qual a integração regional é apenas uma alternativa plausível para a convivência com o processo de globalização das economias.

A mensuração das ligações industriais e a identificação de setores-chave a partir das técnicas de Rassmussem e Hirschmam indicam, no Mercosul, dois padrões bem diferenciados: ligações industriais fortes no Brasil e fracas na Argentina, Chile e Uruguai. O conjunto de setores-chave evidencia que o Brasil possui uma indústria diversificada que está centrada nas indústrias de produção de matéria-prima e indústrias manufatureiras. Na Argentina, os setores-chave identificados apontam que sua economia 
é diversificada, assemelhando-se à do Brasil, porém isso tudo dentro de um padrão médio industrial de ligações fracas. Já, nos setores-chave do Chile e do Uruguai, predominam as atividades de mineração e agropecuárias, respectivamente, seguidas de serviços industriais, comércio e transporte. Em decorrência desses fatos, os baixos índices de ligações para frente de algumas indústrias da Argentina, Chile e Uruguai frente aos dọ Brasil, tais como metalurgia básica, mecânica, material elétrico, material eletrônico e material de transporte, com maior ênfase no Uruguai e no Chile, indicam que as atividades de produção básicas para a implementação de um processo amplo de industrialização de suas economias não são consistentes.

De acordo com o tamanho dos índices de ligações de Rassmussem e Hirschmam, os setores-chaves que mais dinamizam a economia do Mercosul, em sua maior parte, concentram-se na economia brasileira. Ressalte-se, contudo, que esses índices não mostram os elos que processam as ligações intersetoriais mais relevantes na economia, ou seja, não especificam se a importância das ligações intersetoriais deriva preponderantemente do comércio entre países ou do comércio entre as indústrias de cada país. Contudo, os coeficientes setoriais com maior campo de influência no Mercosul indicam que os principais elos de ligações inter-regionais da economia do Mercosul são dominados, em sua maior parte, pelos setores-chave vinculados à economia brasileira. Os índices puros utilizados para ordenar as regiões em termos de sua importância no valor da produção que geram confirmam a predominância brasileira.

Em decorrência desses fatos, conclui-se que o perfil de uma rápida e maior interdependência setorial na região será determinado pelo mercado brasileiro em virtude da sua melhor articulação intersetorial, processo que se fará principalmente a partir dos setores metalúrgico, têxtil e da agropecuária, até porque esses setores participam nas cadeias produtivas dos diversos setores-chave da Argentina, do Chile e do Uruguai. Entretanto, essas ligações intersetoriais, que salientam a importância da economia do Brasil não necessariamente implicam que os beneficios derivados do comércio interregional se concentrem na economia brasileira, mesmo porque este tipo de interpretação dos resultados levaria a incorrer em um erro "contra-intuitivo". Na verdade, as relações 
intersetoriais de alcance inter-regional identificadas no Brasil através dos coeficientes do campo de influência resgatam, nitidamente, a predominância de elos de ligações para trás (importações) e esses por sua vez, associados às maiores potencialidades de ampliação da demanda para a Argentina, Chile e Uruguai do que para o Brasil, sugerem, no mínimo, que os mercados são potencialmente complementares.

De acordo com a estrutura da matriz insumo-produto internacional do Mercosul, as importações de cada país são as exportações dos países parceiros. Quando a demanda de um país varia, para os países exportadores, entre outros efeitos, os fluxos de comércio aumentam as atividades de produção doméstica, gerando valor adicionado e maior interdependência inter-regional. Contudo, o efeito total de uma unidade adicional na demanda de um país não se obtém numa primeira etapa, mas num conjunto de etapas contínuas até que a demanda e a oferta de suprimento estejam equilibradas, isto é, através de um processo multiplicador do tipo keynesiano. Desde que se saiba que os multiplicadores setoriais são maiores do que 1 , a produção, o valor adicionado e 0 comércio inter-regional se modificarão em relação à variação inicial da demanda mais que proporcionalmente. Portanto, quando é modificada a demanda final em um país, surgirá um processo que repercutirá na produção e nos mercados dos países com os quais aquele mantém relações comerciais.

Mensurar esses processos que implicam efeitos diretos e indiretos nas cadeias de produção permite avaliar as vantagens de maior ou menor interdependência comercial nacional e/ou internacional. Nesse sentido, a produção induzida pelas demandas finais expressa e confirma, em termos relativos, a maior inserção da economia chilena e uruguaia no mercado internacional em relação às economias da Argentina e do Brasil, já que a dependência da produção em relação à demanda externa é elevada no Chile e no Uruguai e pequena na Argentina e no Brasil. No entanto, em virtude da dimensão econômica de seus mercados, estes últimos lideram a capacidade de induzir maiores níveis de produção no Mercosul. Os coeficientes de produção induzida, em geral, sugerem uma forte relação entre a demanda doméstica final e a produção doméstica, 0 . 
que faz com que aumentos na demanda final dos países resultem em grandes aumentos na produção das indústrias domésticas.

A análise intersetorial desagregada dessas relações indica, através do grau de dependência doméstica, características diferentes entre os países: dependência doméstica elevada em todos os setores brasileiros; a Argentina mostra características assemelhadas às do Brasil, exceto no setor agropecuário; onde sua dependência doméstica é baixa, aparecendo como um grande exportador de produtos agrícolas no mundo; no Chile e no Uruguai, a dependência doméstica, em geral, é relativamente baixa - em particular, nos setores da agropecuária, serviços industriais públicos, manufaturas e transporte -, contudo a indústria de mineração determina uma diferença fundamental entre os dois países, ou seja, o consumo interno do Chile por minérios é extremamente baixo, de tal forma que suas exportações apresentam características de escala mundial.

A análise ainda mais desagregada que confronta a dependência doméstica de cada setor com sua respectiva produção doméstica bruta permite identificar setores produtivos que têm laços importantes com o mercado externo. Os resultados, em geral, indicam, na estrutura de transações internacionais, que as exportações das indústrias agropecuárias e das indústrias de processamento de recursos primários da Argentina têm um papel importante. O Uruguai também apresenta essas características, porém em menor dimensão. No Chile, destacam-se as indústrias de extração mineral, transporte e agropecuária. Contrariamente a essas características, no Brasil, as exportações são diversificadas, não estando somente limitadas às indústrias de exportação de matériaprima e de processamento de matéria-prima, pois também incluem um forte componente de indústrias secundárias leves e pesadas de larga escala.

Em decorrência desses fatos, os fluxos de comércio internacional para induzir a produção nos países do Mercosul apontam, em termos relativos, que, na estrutura de transações inter-regionais, existe desigualdade nos efeitos benéficos que os países usufruem. Em particular, os efeitos benéficos se concentram no Brasil uma vez que, enquanto o volume das importações que o Brasil faz de seus países parceiros é, predominantemente, de recursos naturais e produtos primários de simples processamento 
que têm ligações relativamente fracas em seus países de origem, as importações que os países parceiros fazem da economia brasileira são de produtos industriais leves e pesados, que têm grande repercussão na produção em virtude do seu maior valor adicionado.

Por sua vez, os efeitos na produção induzida que a Argentina concede aos parceiros repercutem com maior força benéfica nas economias. Quanto à economia chilena, em média, assemelha-se aos padrões argentinos. Ressalte-se ainda que, na estrutura de dependência setorial externa, os fluxos de comércio indicam que são mais fáceis as exportações de produtos com maior valor adicionado entre a Argentina, o Chile e o Uruguai do que deste grupo de países para o Brasil. Contudo, o Uruguai, que apresenta um padrão médio de ligações industriais fracas, tem benefícios importantes em sua economia quando exporta na região já que, em sua pauta de exportações, predominam produtos que têm origem em setores-chave. Isso indica, em termos de efeitos diretos e indiretos, que a importância relativa das exportações, com seus correspondentes beneficios, poderá variar de acordo com as modificações que ocorrerem na pauta de exportações associadas a setores-chave de cada país. Conclui-se, portanto, que políticas desenhadas para distribuir e/ou gerenciar melhor os beneficios da produção entre os países parceiros devem estar fundamentadas em produtos ligados a setoreschave. Para isso, e dependendo dos objetivos que se perseguem, estudos específicos devem ser realizados.

Os impactos decorrentes das ligações interindustriais de produção na geração de valor adicionado indicam, no comércio inter-regional, que as demandas finais dos países geram maiores volumes de valor adicionado no Brasil, seguido de longe pela Argentina. O confronto da produção doméstica total per capita e a participação relativa do valor adicionado induzido doméstico mostram, no Mercosul, que a dependência externa do Chile e do Uruguai nos próximos anos, em termos relativos, aumentará bem mais que a dependência externa da Argentina e do Brasil. Isso porque as economias chilena e uruguaia, em razão da sua imaturidade nos setores de materiais básicos industriais, normalmente importam bens de capital e materiais intermediários para estimular a produção de suas indústrias que estão orientadas para a exportação. À medida 
que se intensifique esse processo com a abertura do mercado regional, diminuirá sua dependência doméstica já que aumentarão as importações. Portanto, os países do Mercosul são complementares e as perspectivas de uma maior interdependência comercial na região são promissoras, a menos que a estrutura e o nível do comércio se alterem drasticamente em favor do resto do mundo.

Os coeficientes de valor adicionado induzidos no Brasil pelas demandas da Argentina, Chile e Uruguai apresentam-se como os mais altos na região. Esse fato, associado aos níveis de industrialização alcançados pelo Brasil, mostra também a importância relativa da economia brasileira como um supridor de produtos acabados de materiais básicos industriais e de bens de capital para os países do Mercosul. Portanto, torna-se claro que, à medida que o processo de desenvolvimento avançar na região, acompanhado de maior interdependência industrial, o valor adicionado no Brasil aumentará; já, na Argentina, esse processo não deve ser tão expansivo, porque a industrialização de sua economia não está consolidada. A participação dos setores primários sobre o total do valor adicionado de cada país sintetiza a natureza e/ou origem do valor adicionado induzido no Mercosul, ou seja, na Argentina, Chile e Uruguai, a participação relativa dos setores primários é elevada e, no Brasil, pequena.

Em virtude dos prováveis aumentos de interdependência setorial na região, a mensuração da influência das demandas finais sobre o comércio inter-regional indica que as economias da Argentina, Uruguai e Chile apresentam, em relação ao Brasil, maior capacidade relativa para induzir importações no Mercosul, ou seja, o Brasil apresenta maior capacidade para exportar do que para importar; o inverso é verdadeiro para os países parceiros. Os coeficientes de importações induzidas elevados de Chile, Uruguai e, em menor grau, da Argentina em relação ao Brasil corroboram essa característica. Em particular, os elevados coeficientes de Chile e Uruguai devem-se, em parte, ao fato de as importações de bens de capital e de diversos materiais para o funcionamento de suas indústrias serem uma necessidade estrutural de suas economias.

A mensuração das exportações induzidas indica, em nível agregado, que o comércio no Mercosul é dinamizado, em sua maior parte, pelas economias da Argentina e 
do Brasil e que os fluxos de comércio por origem e destino os apresentam como os maiores parceiros da região. Em nível setorial, a importância relativa de setores primários de exportação é mais relevante na Argentina, Uruguai e Chile; contrariamente, no Brasil, destacam-se setores secundários de exportação. Esses fatos, associados à considerável diversidade de setores e produtos envolvidos nas transações inter-regionais, indicam que, na complementaridade econômica dos mercados, existirá uma tendência à especialização no comércio de setores que apresentam tradicionalmente os maiores volumes de exportação, havendo uma diversificação ampla do comércio em setores de menores volumes exportados, até porque o intercâmbio comercial, neste nível, processa-se entre setores primários e secundários da mais variada índole.

Em síntese, as ligações intersetoriais fortes e setores-chave de alcance inter-regional do Brasil, bem como a complementaridade econômica na geração de produção, de valor adicionado e de comércio externo entre a Argentina, Brasil, Chile e Uruguai, além das maiores potencialidades de ampliação da demanda para a Argentina, Chile e Unguai, do que para o Brasil, permitem aceitar a hipótese de que setores vinculados às economias que apresentam melhor articulação de suas indústrias possuem maior poder de encadeamento inter-regional para promover o crescimento econômico e maior interdependência comercial na região. Entretanto, considerando a gritante desigualdade na dimensão econômica das estruturas de produção e consumo dos países, bem como no desenvolvimento industrial, a maior interdependência comercial deverá ser acompanhada de medidas corretivas tendentes a um processo de crescimento econômico conjunto na região.

Obviamente, a presente pesquisa apresenta limitações; portanto sugere-se a realização de pesquisas complementares e de aprofundamento para a construção de políticas tendentes ao desenvolvimento econômico na região. A respeito, destacam-se, do ponto de vista do insumo-produto, a necessidade de: a) mensurar e qualificar no tempo a distribuição dos custos e beneficios derivados do comércio inter-regional; b) analisar as estruturas produtivas em nível de produtos principais; c) analisar a complementaridade e competitividade do agribusiness do Mercosul; d) construir e atualizar matrizes nacionais 
com uma data básica; e) incorporar as matrizes regionais de cada país na matriz do Mercosul com o objetivo de diferenciar os impactos econômicos nos diferentes segmentos territoriais de cada país; f) interligar a matriz do Mercosul com as matrizes nacionais de países que mantêm fluxos de comércio relevantes; g) compatibilizar e atualizar as classificações do comércio exterior com as classificações das atividades econômicas dos países, bem como das estatísticas de frete e seguro internacional e h) realizar pesquisas que incorporem mudanças nas taxas de câmbio e preços relativos, já que o modelo as considera constantes. 
.

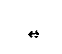




\section{REFERÊNCIA BIBLIOGRÁFICA}

ADAMS, R. Agricultura e agroindústria no Cone Sul. In: SEITENFUS, V. \& BON, L. Temas de integração latino-americana. Porto Alegre: UFRGS, 1990. p.197-217. ANDERSON, M. Estimación de los beneficios de la integración éconómica em America Latina. Integración Latinoamericana, ano 11, n. 113, p.33-72, Jun. 1986.

ANDIC, F. \& TEITEL, S. Integración económica: El Trimestre Economico, n.19, p.227, 1977.

AZZONI, C. R. Indústria e reversão da polarização no Brasil. São Paulo: IPE/USP, 1985.

AZZONI, C. R. Equilíbrio progresso técnico e desigualdades regionais no processo de desenvolvimento econômico. Revista Análise Econômica, ano 11, n. 19, p. 5 - 28 , 1993.

BAUMANN, R. Uma visão econômica da globalização. In: BAUMANN, R. O Brasil e a economia global, São Paulo: ABDR/Ed. Afiliada, 1996. p.33-51.

BEKERMAN, M. \& SIRLIN, P. Politica comércial e inserción internacional de la Argentina para los años 90. Revista de Economia Política. v. 16. n.3(63), jul/set. 1996.

BERRETTA, N. El marco institucional del comércio regional: antecedentes e nacimiento del Mercosul. In: BERRETTA, N. \& LORENZO, F. \& PALOMINO, C. Em el umbral de la integración. São Paulo: Ed. Banda Oriental-cinve. nov. 1993. p.19-54. 
BCA. Estimacion del cuadro de insumo-produto de los sectores productores de bienes 1984. Buenos Aires: Ed. Secretaria de la Planificación / Instituto Nacional de Estadísticas y censos, 1986.

BCC. Matriz de insumo-produto para la economia chilena 1986. Santiago de Chile: Ed. Departamento de Publicaciones del Banco Central de Chile, octubre, 1992.

BCU. Matriz de insumo-produto de 1983. In: Cuentas Nacionales de 1991. Montevideo: Ed. Departamento de Estadisticas Economicas del Banco Central del Uruguay, 1991. p.b3-b32.

BID. Progresso sócio-econômico na América Latina. Integração econômica. Relatório de 1984, Washington, 1984.

BOM, R. Comparative stability analysis of multiregional input-output models. The Quarterly Journal of Economics. p. 791-815, nov.1984.

BULMER V. Input-output analysis in developing countries. New York: John Wiley. 1982.

CARNOY, M. Analisis del bienestar de la unión económica latinoamericana: Seis Estudios Industriales, 1970. El Trimestre Económico. n. 19, p.604-642, 1977.

CAVALCANTI, J. Avaliação do padrão de desenvolvimento da economia do Nordeste, período 1975-1980. Revista Brasileira de Economia, v.1, n. 48, p.107-124, jan/mar. 1994.

CELLA, G. The input-output measurement of interindustry linkanges. Oxford Bulletin of Economic and Statistics, v.46, p.73-84, 1984.

CEPAL. Estudio Econômico de América Latina. Santiago do Chile: Nações Unidas (E/CN 12/164 rev. 1), 1951.

CEPAL. Significación del Mercado Comum en el desarrollo econômico de América Latina. In: SALGADO, P. Económia de la integración latino-americana. Lecturas Seleccionadas. BD. 1990. p. 139-154.

CHENERY, H. Regional analysis. In: CHENERY, H \& CAO-PINA. The structure and growth of Italian economy. Rome: U.S. Mutual Security Agency, 1953.

CLEMENTS, B. On the decomposition and normalization of interindustry linkages. Economics and statistics, v.46, p.73-84, 1984. 
CLINE, W. Estratégia de las negociações para la integración latino americana. In: SALGADO, P. Economia de la iIntegración latinoamericana. Lecturas Seleccionadas. BD. p. 347-368, 1990.

CONESA, E. ALADI: Uma esperanza renovada. Revista de Integración Latino americana. v. 4. n. 47, p. 1-3, jun. 1980.

CONESA, E. Conceptos fundamentales de la integración latino americana. Revista de Integración Latinoamericana v.7, n.71, p.2-27, ago. 1987.

DIXOM, P. \& PARMENTER, B. \& POWELL, A. \& WILCOXEM, P. Notes and problems in applied general equilibrium economics. Amsterdam: North-Holland, 1992.

ELLSWORTH, P. T. Economia internacional. São Paulo: Atlas, 1978.

EZCURRA, A. La nación de Repúblicas: proyecto latinoamericano del libertador. Caracas: Ed. Mist. Relações Exterioros de Venezuela, 1988.

FERREIRA, A. \& DINIZ, C. Convergência entre as rendas per capita estaduais no Brasil. Revista de Economia Politica, v. 15, n. 4(60), p.38-56, out. 1995.

FUIA. La Política Comercial externa. Cuaderno n.5, 1989.

FURTADO, C. Desenvolvimento e subdesenvolvimento. Rio de Janeiro: Fundo de Cultura, 1961.

FURUKAWA, S. International input-output analysis: compilation and case studies of interaction between ASEAN, Korea, Japão, and the United States, 1975. Tohyo: Intitute of developing economies, 1986.

GRIMWADE, N. Internacional trade. New patterns of trade, production and investment. Londres e New York: Routledge, 1989.

GRUPO ANDINO. Notas explicativas al reparte consolidado de aranceles. Lima: Ed. JAC, 1978.

GUERRA, A. Nuevo contexto mundial para America Latina. Integración Latinoamericana. n.192, ago. 1993.

GUILHOTO, J. Um modelo computável de equilíbrio geral para planejamento e análise de políticas agrícolas (Papa) na economia brasileira. Piracicaba, 1995. Tese (Livre-Docência) - USP/ESALQ/DESR. 
GUILHOTO, J., SONIS, M., HEWINGS, G., E MARTINS, E. Indices de ligações e setores-chave na economia brasileira: 1959/80. Revista Pesquisa e Planejamento Economico, v.24, n.2, p.287-314, ago. 1994.

GUILHOTO, J., SONIS, M., HEWINGS, G. Linkages and multipliers in a multiregional framework: integration of alternative approaches. Regional Economics Applications Laboratory (Real). Disccussion paper, nov. 1996.

GUTIERRES,J.E. A integração Brasil Argentina: um estudo da competitividade na produção de grãos, Porto Alegre, 1988. Dissertação (M.S.) - IEPE-UFRGS.

HADDAD, P. \& ANDRADE, T. Política fiscal e desequilíbrios regionais. Estudos Econômicos, v.4, n.1, p.9-54, jan/maio. 1974.

HADDAD, P. Contabilidade social e economia regional: análise de insumo-produto. Rio de Janeiro: Zahar Editores, 1976. 242p.

HADDAD, P. Métodos de analise de setores-chave e de complexos industriais. In: HADDAD, P. (Org,). Economia regional: teoria e métodos de análise. Fortaleza: BNB/ETENE. 1989. p.399-426.

HANSEN, W. \& TIEBOUT, C. An intersectoral flow analysis of the California economy. The Review of Economics and Statistics, n.45, p. 409-418, 1963.

HEWINGS, G. The empirical identification of key sectors in an economy: a regional perspective. The Developing Economies, v.20, p.173-195, 1982.

HIRSCHMAN, A. The strategy of economic development. New Haven: Yale University Press, 1958.

HIRST, M. \& STREB, M. Los esquemas de integración: desarrollos recientes del proceso de integracion em América Latina. In: Situación Latino Americana-Aeci. Madrid: Editora Fundação Cedeal, p. 1-33, 1993.

IBGE. Matriz de Insumo-Produto. Brasil. 1980. Rio de Janeiro. 1989.(Séries Relatórios Metodológicos, 7) 230p.

IBGE. Matriz de Insumo-Produto. Brasil. 1990. Rio de Janeiro (Departamento de Contas Nacionais), 1996.

INTAL. El processo de integración em América Latina em 1980. Buenos Aires: Ed. INTAL, 1981. 
ISARD, W. Interregional and regional input-output analysis: a model of a spaceeconomy. Review of Economics and Statistics, n.33, p.319-328, 1951.

ISARD, W. Methods of regional analysis. cap.8, MIT Preaa, 1960.

LANGONI, C. Apresentação dos economistas. In: LEONTIEF, W. A economia de insumo-produto. p.VII-XVII, Ed. Fundo de cultura, São Paulo, 1983.

LEONTIEF, W. \& HOFFENBERG, M. Os efeitos economicos do desarmamento. In: LEONTIEF, W. A economia do insumo-produto. São Paulo: Ed. Fundo de cultura, 1983. p. 97-102.

LEONTIEF, W. \& HOFFENBERG, M. The economic effect of disarmanent. In: Scientific American, abr. 1961.

LEONTIEF, W. \& MORGAN, A. \& POLENSKE, K. \& SIMPSON, D. \& TOWER, E. The economic impact - industrial and regional - of an arms cut. Review of Economics and Statistics, n. 47, p.217-241, 1965.

LEONTIEF, W. \& STROUT, A. Multiregional input-output analysis. In: BARNA, T. (org.) Structural interdependence and economic development, Ed. Macmillan, 1963.

LEONTIEF, W. A economia do insumo-produto. São Paulo: Ed. Fundo de cultura, 1983. 227p.

LEONTIEF, W. The structure of the americam economy. 2. ed. ampliada. New York: Oxford University Press, 1951.

LEONTIEF, W. Interregional theory. In: LEONTIEF, W. Studies in the structure of the american economy. New York: Oxford University Press, 1953.

LEONTIEF, W. Studies in the structure of the american economy. Parte II. New York: Ed. Oxford, University Press, 1963.

LEONTIEF, W., MORGAN, A., POLENSKE, K., SIMPSON, D., TOWER, E. O impacto econômico - industrial e regional - de uma redução de armas (1965). In: LEONTIEF, W. A economia do insumo-produto. São Paulo: Ed. Fundo de cultura, 1983.

LIZANO, E. Problemas actuales de la integración económica. La distribuición de los benefícios y costos en la integración entre paises en desarrollo. In: Conferéncia de 
las Naciones Unidas sobre Comercio y Desarrollo. Ginebra, jul. 1972, New York, p.25-111, 1973.

MALDONADO, P. Integración latino americana: los resultados de la balanza comercial y la distribuición de los custos y beneficios. INTAL, Premio 1985. Buenos Aires: Inta, p.13-79, 1986.

McGILVRAY, J. Linkages, key sectors and development strategy. In: LEONTIEF,W.(ed.). Structure, system and economic policy. Cambridge: University Press, 1977. p.49-56.

MEADE, D. C. The distribution of gains in custons unions between developing countries. Kyklos. v.21, 1968.

METZLER, L. A multiple-região theory of income and trade. In: Econométrica, v. VIII, p.329-354, oct. 1950.

MILLER,R.E. e BLAIR,P.D. Input-Output Analysis: Foundations and Extensions. Englewood Cliffs: Prentice-Hall.1985.

MONTOYA, M. Os custos e benefícios da integração econômica: uma análise do comércio intrarregional do Grupo Andino. Porto Alegre, 1991. 219p. Dissertação (M.S.) IEPE/UFRGS.

MONTOYA, M. A. Os custos e benefícios da integração econômica regional. Revista Análise Econômica. Ano. 11, n. 19 p.136-153, mar. 1993.

MONTOYA, M. \& CHAMINADE, M. Teoria e praxe da integração econômica na América Latina: uma abordagem dos desequilíbrios regionais. Revista Teoria e Evidência Econômica. UPF. Ano 2. n. 4. p. 61-94. nov. 1994.

MOSES, L. The stability of interregional trading patterns and input-output analysis. The American Economic Review, n. 45, p. 803-832, 1955.

MYRDAL, G. Solidaridad o desintegración. México: DF, Fondo de Cultura Económica, 1957.

MYRDAL, G. Teoria econômica e regiões subdesenvolvidas. 2. ed. Rio de Janeiro: Saga, 1968.

NAÇÕES UNIDAS. Problemas que plantean los quadros y el analisis insumoproduto. n.14, série F, New York, 1966. 
PERERA, L. Tratado de Assunção: resultados e perspectivas. In: BRANDÃO, e PEREIRA, L. Mercosul, perspectiva da integração. FGV. Ed. Segunda. 1997, p. $11-46$.

PERROUX, F. Conceito de pólos de crescimento (1955). In: SCHWARTZMAN, J. Economia regional - Textos escolhidos. Belo Horizonte: Cedeplar, p.145-156, 1977.

POLENSKE, K. An empirical test of interregional input-output models: estimation of 1963 japonese production. American Economic Review, p.76-82, maio 1970.

PRAXEDES, W. \& PILETTI, N. História em movimento: o Mercosul e a sociedade global. São Paulo: Ed. Ática, 7. ed. 1996. 88p.

PREBISCH, R. O desenvolvimento econômico da América Latina e seus principais problemas. Revista Brasileira de Economia. v.3,n.3, p. 47-111. set. 1950.

RASMUSSEN, P. N. Studies in inter-sectorial relations. Amsterdam: North-Holland, 1956.

RICHARDSON, H. Input-output and regional economics. London: Ed. Weidenfeld and Nicolson, 1972.

ROUNDT, J. An interregional input-output approach to the evaluation of nonsurvey methods. Jounal of Regional Science, v. 18, n. 2, 1978.

ROUNDT, J. Nonsurvey techniques: a critical review of the theory an the evidence. International Regional Science Review, v. 8, n. 3, p.189-212, 1983.

ROUNDT, J. Regional input-output models in the U.K.: a reappraisal of some techniques. Regional Studies, n. 6, p.1-9, 1972.

SALGADO, G. Los padrones de uma integración viable y sus Modalidades. In: SALGADO, G. Economia de la integración latinoamericana. Intal. 1990. p. 159184.

SANDRONI; P. Novo dicionário de economia. Ed. Best Seller, 1994. p. 375.

SANTOS, T. Economia mundial: integração regional \& desenvolvimento sustentável. Porto Alegre: Ed. Vozes, 1993. 144p.

SECEX. Balança comércial brasileira-Mercosul. Sincomex, jan/jul. 1997. 
SLVA, C.J. Antecedentes históricos do processo de integração latino americana: Alalc, Mcca, Pacto Andino. In: SEITENFUS, V. \& BONI, L. Temas de integração latino americana. Porto Alegre: Ed. Vozes, jun. 1990. p. 32-81.

SÍNTESIS ALADI. Jun. 1985.

SONIS, M, HEWINGS, G. J. D. Fields of influence in input-output systems. Urbana: University of Illinois, Regional Economics Applications Laboratory, 1994, mimeo.

SONIS, M., HEWINGS, G. J. D. Error and sensitivity input-output analysis: a new approach. In: MILLER,R.E.; POLENSKE,K.R, ROSE,A.Z.(eds). Frontiers of input-output analysis. New York: Oxford University Press, 1989.

SOUZA, N. Desenvolvimento polarizado e desequilíbrios regionais no Brasil. Revista Análise Econômica. Ano.11, n.19, p. 29-59, mar., 1993a.

SOUZA, N. Desenvolvimento econômico. São Paulo: Ed. Atlas, 1993b. 242 p.

STEIN NETO, B. A vitivinicultura do Rio Grande do Sul e a integração econômica Brasil-Argentina. Porto Alegre, 1991. Disertação (M. S.) IEPE/UFRGS.

TUSSIE, D. Nuevas rutas de la integración latino-americana, de la substituición de importaciones y la eficiencia mercantil. Revista de Comércio Exterior. Mexico, v.1, n.2, p.1397-1403, 1981.

VILLWOCK, L. Os impactos economicos do Mercosul sobre as cadeias de produção do trigo, soja, milho, suino e aves. Porto Alegre, 1993. Dissertação (M.S.), IEPE/UFRGS.

VINER, J. The custons union issue. New York: Carnegie Endowment for International Peace, 1950.

WAQUIL, P. Primal-dual spatial equilibrium model with intermediate products: aplication to the agricultural sector in the Mercosur. Wisconsin, 1995. Dissertation (Ph D.) - University of Wisconsin.

WILLIAMSON, J. Desigualdade regional e o processo de desenvolvimento nacional: descrição dos padrões. In: SCHARTZMAN, J. Economia Regional: Textos escolhidos. Belo Horizonte: Cedeplar, 1977. p.15-52. 
APÊNDICES 


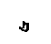


APÊNDICES 1 - A MATRIZ INSUMO-PRODUTO DO MERCOSUL 1990 
Tabela A1.1 . Classificação setorial da demanda intermediária da matriz insumoproduto internacional do Mercosul 1990.

\begin{tabular}{c|l}
\hline Setores & \multicolumn{1}{|c}{ Descrição } \\
\hline 001 & Agropecuária, Extração Vegetal, Silvicultura, Caça e Pesca \\
002 & Extração Mineral (exceto combustíveis) \\
003 & Petróleo Cru, Gás Natural, Carvão e Outros Combustíveis \\
004 & Mineração não Metálica e Fabricação de Produtos \\
005 & Indústria Metálica Básica, Metalurgia de não Ferrosos e Fabricação de Produtos \\
006 & Fabricação e Manutenção de Máquinas e Tratores (mecânica) \\
007 & Fabricação de Material Elétrico \\
008 & Fabricação de Equipamento Eletrônico \\
009 & Fabricação de Material de Transporte e Diversos \\
010 & Produtos da Madeira e Mobiliário \\
011 & Papel, Celulose, Papelão e Gráfica \\
012 & Indústria da Borracha \\
013 & Quimica Básica \\
014 & Refino do Petróleo e Derivados \\
015 & Fabricação de Químicos Diversos e Indústria Farmacêutica e de Perfumaria \\
016 & Indústria de Artigos de Plástico \\
017 & Indústria Têxtil \\
018 & Fabricação de Artigos do Vestuário \\
019 & Indústria do Couro, Produtos e Calçado \\
020 & Beneficiamento de Produtos Vegetais \\
021 & Abate de Animais e Carnes \\
022 & Indústria de Laticinios \\
023 & Fabricação e Refino de Açúcar \\
024 & Fabricação de Óleo Vegetal e Animal \\
025 & Fabricação de Outros Produtos Alimentares \\
026 & Indústria de Manufaturas Diversas \\
027 & Serviços Industriais de Utilidade Pública \\
028 & Construção Civil \\
029 & Comércio \\
030 & Transporte \\
031 & Serviços \\
\hline & Total Consumo Intermediário: 001 + 002 + 003 + ... + 031 \\
\hline
\end{tabular}


Tabela A1.2 . Classificação setorial da demanda finala da matriz insumo-produto internacional do Mercosul 1990.

\begin{tabular}{c|l}
\hline Demanda & \\
Final & \\
001 & Consumo das Famílias \\
002 & Consumo do Governo \\
003 & Formação de Capital Fixo \\
004 & Variação de Estoque \\
& Total Demanda Final: $001+002+003+004$ \\
\hline
\end{tabular}

Tabela A1.3 . "Coordenada" da matriz insumo-produto internacional do Mercosul: descriç̃o das linhas.

\begin{tabular}{l|l}
\hline \multicolumn{1}{c|}{ Descrição } & Linha \\
\hline Insumos Intermediários Domésticos - Argentina & 001 a 031 \\
Insumos Intermediários Domésticos - Brasil & 032 a 062 \\
Insumos Intermediários Domésticos - Chile & 063 a 093 \\
Insumos Intermediários Domésticos - Uruguai & 094 a 124 \\
Total dos Insumos Intermediários Domésticos & 125 \\
Seguro e Frete Internacional & 126 \\
Importações CIF do resto do mundo & 127 \\
Impostos sobre as importações & 128 \\
Valor Adicionado & 129 \\
Total insumos & 130 \\
\hline
\end{tabular}

Tabela A1.4 . "Coordenada" da matriz insumo-produto internacional do Mercosul: descricão das colunas.

\begin{tabular}{l|l}
\hline \multicolumn{1}{c|}{ Descrição } & Colunas \\
\hline Insumos Intermediários Domésticos - Argentina & 001 a 031 \\
Insumos Intermediários Domésticos - Brasil & 032 a 062 \\
Insumos Intermediários Domésticos - Chile & 063 a 093 \\
Insumos Intermediários Domésticos - Uruguai & 094 a 124 \\
Total dos Insumos Intermediários Domésticos & 125 \\
Demanda final - Argentina & 126 a 129 \\
Demanda final - Brasil & 130 a 133 \\
Demanda final - Chile & 134 a 137 \\
Demanda final - Uruguai & 138 a 141 \\
Total das demandas finais & 142 \\
Exportações FOB para o resto do mundo & 143 \\
Inventário em trânsito e discrepâncias estatísticas & 144 \\
Total da produção & 145 \\
\hline
\end{tabular}




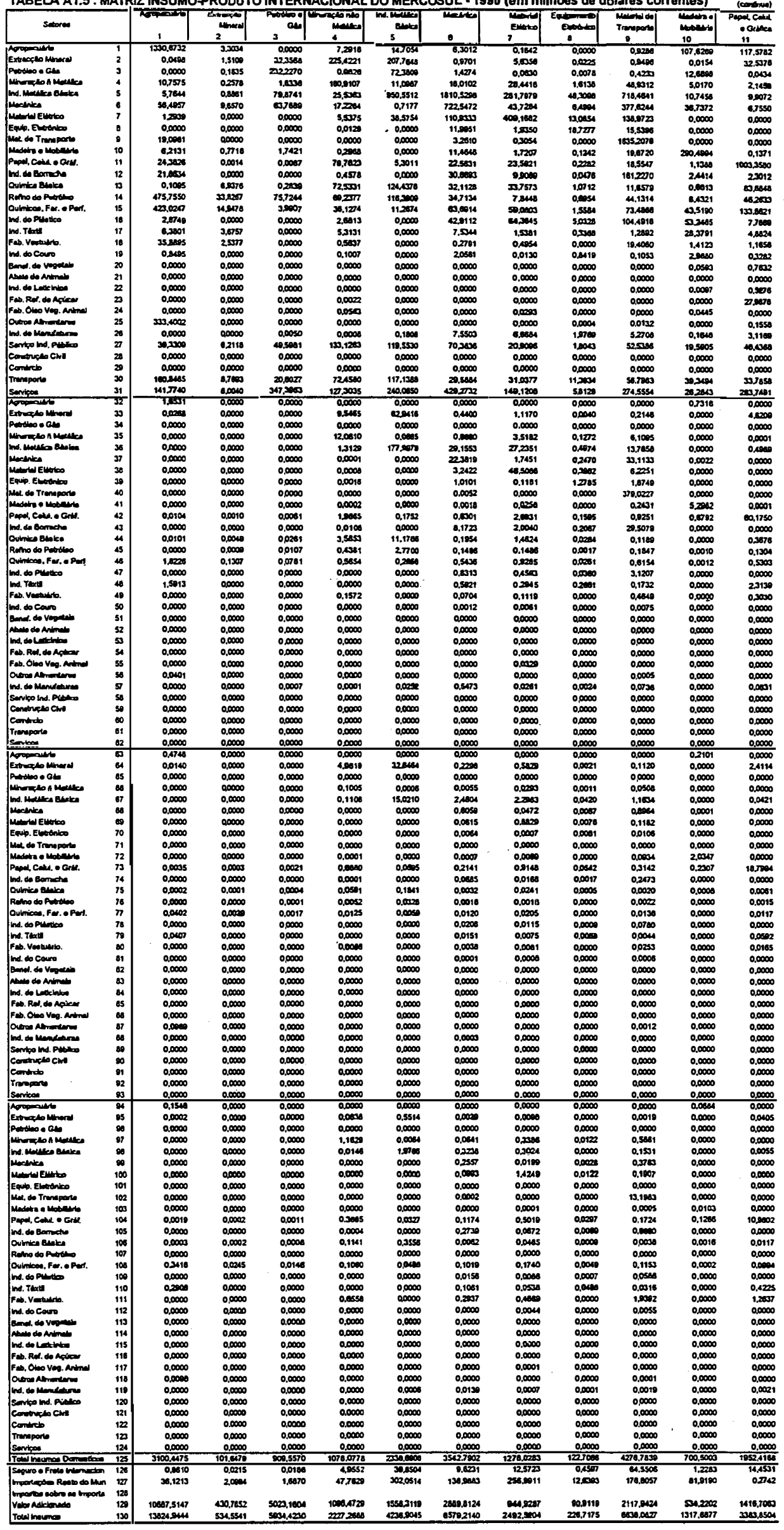




\begin{tabular}{|c|c|c|c|c|c|c|c|c|c|c|c|c|}
\hline The & & 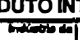 & काता & $-\ldots$ & $x_{n}=0$. & $-\infty$ & mistos & de dolar & 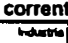 & Eक्रता & $m \infty$ & 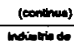 \\
\hline sement & & & 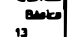 & 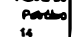 & $\approx=$ & Pluturos & $T$ & $x=$ & doccomon & valus & 年 & 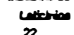 \\
\hline & & & & & & & & & & & $\mathrm{m}$ & . \\
\hline now & 3 & 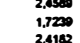 & 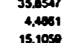 & $\begin{array}{l}3,301 \\
5001.722 \\
00001\end{array}$ & $\begin{array}{l}102164 \\
18.0247 \\
0502073\end{array}$ & $\begin{array}{l}1.60035 \\
02972 \\
1019\end{array}$ & $\begin{array}{l}0.00010 \\
\mathbf{3} 22009 \\
0.0000\end{array}$ & $\begin{array}{l}0.0000 \\
0.000 \\
0.007\end{array}$ & 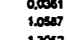 & $\begin{array}{l}0.02001 \\
1.1481 \\
.31010\end{array}$ & $\begin{array}{l}0.0000 \\
0.0000\end{array}$ & $\begin{array}{l}0.00000 \\
0.0000 \\
0.000\end{array}$ \\
\hline 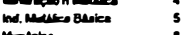 & s & 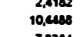 & 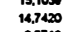 & $\begin{array}{l}8.0061 \\
0.250\end{array}$ & 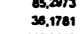 & $\begin{array}{l}1.0120000 \\
122006\end{array}$ & 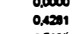 & 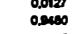 & $\begin{array}{l}1,0002 \\
0.0000\end{array}$ & $\begin{aligned} 11.0002 \\
11002\end{aligned}$ & $\begin{array}{l}0.0000 \\
0.0000\end{array}$ & $\begin{array}{l}1.17800 \\
2.1780\end{array}$ \\
\hline ; & 7 & $\begin{array}{l}72000 \\
0.0000\end{array}$ & $\begin{array}{l}8,9710 \\
7 . \pi 10\end{array}$ & $\begin{array}{l}1100000 \\
0.0000\end{array}$ & 10.0083 & 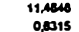 & $\begin{array}{l}2.51,828 \\
0.0000\end{array}$ & $\begin{array}{l}22.0047 \\
0.00000\end{array}$ & $\begin{array}{l}30,020 \\
0.0000\end{array}$ & $\begin{array}{l}75,1000 \\
0.0000\end{array}$ & $\begin{array}{c}13, .0022 \\
0.00000\end{array}$ & $\begin{array}{l}719197 \\
0.0000 \\
0\end{array}$ \\
\hline (1) & : & 0.0000 & 0.00000 & 然 & 20206 & $\begin{array}{l}0.00000 \\
0000\end{array}$ & 0.00000 & . 0.0000 & . 0.0000 & 0.0000 & 0.0000 & 00000 \\
\hline המה & 10 & 0.0223 & 急 & 0.00000 & 2000 & 0.00000 & 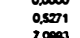 & 0.0075 & inso & sosuo & 20078 & .0.000 \\
\hline comente & 12 & 18.1000 & - & s.7230 & 4000 & 2,9102 & 4.,05s & z2.0\%ss & $\begin{array}{l}70302 \\
53,1220\end{array}$ & 0.0000 & 0.0000 & $\begin{array}{l}2.0000 \\
0.000\end{array}$ \\
\hline 烈 & 14 & 358973 & 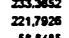 & $\begin{array}{l}35.20201 \\
542005\end{array}$ & 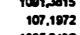 & 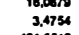 & $\begin{array}{l}2,1,20808 \\
272808\end{array}$ & 15,5130 & $\begin{array}{l}1022008 \\
1028\end{array}$ & $\begin{array}{l}3.0700002 \\
30.002\end{array}$ & 2000 & $\begin{array}{l}3.3212 \\
204522 \\
202\end{array}$ \\
\hline . & 18 & 2,0016 & $\begin{array}{l}56,7116 \\
45,716\end{array}$ & $\begin{array}{l}35.0031 \\
3.0854\end{array}$ & 175.0201 & 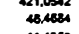 & $\begin{array}{l}72001010 \\
0.0000\end{array}$ & $\begin{array}{l}1060.0150 \\
10.062\end{array}$ & 30.8050 & $\begin{array}{c}3551000 \\
102000\end{array}$ & 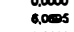 & 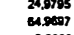 \\
\hline ix & 18 & $\begin{array}{r}r 7,2780 \\
0.7 m 2\end{array}$ & $\begin{array}{l}0.0000 \\
3,0500\end{array}$ & $\begin{array}{l}0.1130 \\
0.0000\end{array}$ & $\begin{array}{l}8.000 \\
0.0019\end{array}$ & $\begin{array}{l}11,0.050 \\
4,7586\end{array}$ & 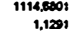 & 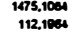 & $\begin{array}{c}\mathbf{0} 0.0 .035 \\
\mathbf{3} .0200\end{array}$ & $\begin{array}{l}0.00000 \\
5,20250\end{array}$ & $\begin{array}{l}0.0000 \\
2004\end{array}$ & $\begin{array}{l}0.0000 \\
0.014 \\
0.45\end{array}$ \\
\hline 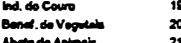 & 总0 & $\begin{array}{l}0.0000 \\
0.0000\end{array}$ & $\begin{array}{l}0.000 \\
0.0000\end{array}$ & $\begin{array}{l}0.0000 \\
0.0000 \\
0.000\end{array}$ & $\begin{array}{l}0.00289 \\
22015\end{array}$ & $\begin{array}{l}0.55500 \\
0.0000\end{array}$ & $\begin{array}{l}0.1200 \\
0.2700\end{array}$ & $\begin{array}{l}2202000 \\
0.0000\end{array}$ & $\begin{array}{r}22,1,7006 \\
0,0003\end{array}$ & $\begin{array}{r}0.0000 \\
0.07 .6252\end{array}$ & 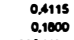 & $\begin{array}{l}0.0001 \\
\text { 3.0250 }\end{array}$ \\
\hline & $\begin{array}{l}21 \\
2 \\
2\end{array}$ & $\begin{array}{l}0.0000 \\
0.0000\end{array}$ & $\begin{array}{l}3.10000 \\
0.0000\end{array}$ & $\begin{array}{l}0.0562 \\
0.0000 \\
0.00\end{array}$ & $\begin{array}{l}101.27718 \\
6,7108\end{array}$ & $\begin{array}{l}0.0000 \\
0.11000\end{array}$ & 年 & 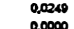 & $\begin{array}{l}75,72780 \\
00000\end{array}$ & 242025 & 20,0001 & 0 \\
\hline 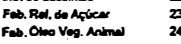 & 24 & $\begin{array}{l}0.0000 \\
0.0000\end{array}$ & 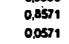 & $\begin{array}{l}0.0000 \\
0.0000\end{array}$ & $\begin{array}{l}.0012 \\
0.0001 \\
0.007\end{array}$ & $\begin{array}{l}0.027 \\
., 2507 \\
.02507\end{array}$ & 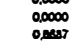 & $\begin{array}{l}0.0000 \\
0.1725\end{array}$ & $\begin{array}{l}0.0000 \\
0.0514\end{array}$ & 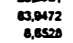 & $\begin{array}{l}0.0000 \\
0.0000\end{array}$ & $\begin{array}{r}302875 \\
0.0000\end{array}$ \\
\hline & & $\begin{array}{l}0.0000 \\
0.0513\end{array}$ & $\begin{array}{l}10.055 \\
0.00056\end{array}$ & $\begin{array}{l}0.0000 \\
0.0000\end{array}$ & 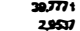 & $\begin{array}{l}0.0000 \\
0.0063\end{array}$ & $\begin{array}{l}0.01828 \\
0.0000\end{array}$ & 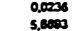 & 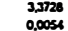 & $\begin{array}{l}70.1000 \\
0000 \\
0.000\end{array}$ & 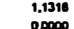 & Theos \\
\hline xind. pastere & $z$ & 150010 & $\begin{array}{l}30.4700 \\
00000\end{array}$ & 17.550 & 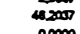 & 21,3065 & 45,5006 & 20.2000 & 27.10007 & $=0000$ & 81,0000 & 14.7502 \\
\hline 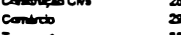 & 2 & $\begin{array}{l}0.00000 \\
0.0000\end{array}$ & 0,00000 & $\begin{array}{l}0.0000 \\
0.0000\end{array}$ & $\begin{array}{l}0.0000 \\
0.0000 \\
0.00\end{array}$ & $\begin{array}{l}0.0000 \\
0.0000\end{array}$ & $\begin{array}{l}0.0000 \\
0.00000\end{array}$ & $\begin{array}{l}0.0000 \\
0.0000 \\
0.000\end{array}$ & $\begin{array}{l}0.0000 \\
0.0000 \\
0.000\end{array}$ & $\begin{array}{l}0.00000 \\
0.00000\end{array}$ & $\begin{array}{l}0.00000 \\
0.0000\end{array}$ & $\begin{array}{l}0.0000 \\
0.0000 \\
0.000\end{array}$ \\
\hline & $\begin{array}{l}30 \\
31 \\
31\end{array}$ & 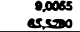 & $\begin{array}{l}28.7533 \\
30.3007\end{array}$ & $\begin{array}{l}1020770 \\
2122401\end{array}$ & 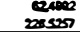 & $\begin{array}{l}\text { ogars } \\
\text { isens }\end{array}$ & 年05000 & 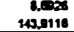 & 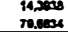 & $\begin{array}{l}4.0076 \\
225101\end{array}$ & 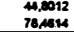 & 19200000 \\
\hline & 32 & $\begin{array}{l}8.17000 \\
0.0017\end{array}$ & $\begin{array}{l}0.1150 \\
11509\end{array}$ & $\begin{array}{l}0.0000 \\
0.0000\end{array}$ & $\begin{array}{l}0.0013 \\
20.073\end{array}$ & 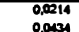 & 0.0020 & $\begin{array}{l}0.0000 \\
0.0000 \\
0.000\end{array}$ & 0.0 .540 & 0.00000 & 0.01302 & 0.0000 \\
\hline - & 34 & 0.0000 & 0.0000 & 0.0000 & 0.0000 & 我 0.0000 & 0.0000 & 0.0000 & 0.0000 & 0.0000 & 0.0000 & $\begin{array}{l}0.0000 \\
0.0000\end{array}$ \\
\hline 等 & 36 & $\begin{array}{l}0.00000 \\
0.00604\end{array}$ & $\begin{array}{l}0.0507 \\
5,2132\end{array}$ & $\begin{array}{l}0.0000 \\
0.0000\end{array}$ & $\begin{array}{l}0.10001 \\
2.050\end{array}$ & $\begin{array}{l}0.0000 \\
0.0000\end{array}$ & $\begin{array}{l}0.00000 \\
0.0000\end{array}$ & $\begin{array}{l}0.0000 \\
0.0000 \\
0.000\end{array}$ & $\begin{array}{l}0.0000 \\
0.0000 \\
0.00\end{array}$ & $\begin{array}{l}0.070608 \\
0.0000\end{array}$ & $\begin{array}{l}0.0000 \\
0.0000 \\
0.000\end{array}$ & $\begin{array}{l}0.0000 \\
0.0000 \\
0.00\end{array}$ \\
\hline 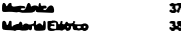 & 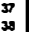 & 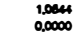 & $\begin{array}{l}00000 \\
0.0000 \\
0.000\end{array}$ & $\begin{array}{l}0.0000 \\
0.0000 \\
0.000\end{array}$ & $\begin{array}{l}0.0000 \\
0.0000 \\
0.00\end{array}$ & 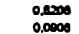 & $\begin{array}{l}0.00000 \\
0.0000\end{array}$ & $\begin{array}{l}0.0000 \\
0.00000 \\
0.00\end{array}$ & $\begin{array}{l}0.0000 \\
0.000\end{array}$ & $\begin{array}{l}0.0000 \\
0.000\end{array}$ & o. 0.00202 & $\begin{array}{l}0.0000 \\
0.0000 \\
0.00\end{array}$ \\
\hline 30 & 30 & 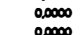 & 然 00000 & $\begin{array}{l}0.0000 \\
0.000 \\
0.000\end{array}$ & $\begin{array}{l}0.0000 \\
0.0000 \\
0.000\end{array}$ & $\begin{array}{l}0.0000 \\
0.000\end{array}$ & $\begin{array}{l}0.0000 \\
00000\end{array}$ & $\begin{array}{l}0.0000 \\
0.000 \\
0.000\end{array}$ & 0.0000 & 0.0000 & . 0.0000 & 0.0000 \\
\hline & 4 & 0,0000 & 000000 & 000000 & 0.0001 & 0.0000 & 0.00000 & 象 000000 & 0.0000 & 0.00000 & 年 & 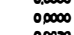 \\
\hline 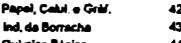 & 4 & 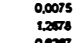 & $\begin{array}{l}0.2004 \\
0.00000 \\
0.000\end{array}$ & $\begin{array}{l}0.038 \\
0.0000 \\
0.000\end{array}$ & $\begin{array}{l}0.0500 \\
20050 \\
2000\end{array}$ & $\begin{array}{l}0.5624 \\
5.1775 \\
.075\end{array}$ & $\begin{array}{l}0.0213 \\
0.0707\end{array}$ & $\begin{array}{l}0.510 \\
0.0000 \\
0.000\end{array}$ & $\begin{array}{l}0.00000 \\
0.0000\end{array}$ & $\begin{array}{l}0.00000 \\
0.000\end{array}$ & 0.0000 & 年 \\
\hline 4 & 45 & 0.00002 & $\begin{array}{l}10.2024 \\
10.5517 \\
1\end{array}$ & (i) & 2000 & $\begin{array}{l}0.0550 \\
0.0171 \\
0.777\end{array}$ & $\begin{array}{l}1.1001 \\
0.0047 \\
5.002\end{array}$ & 年 & $\begin{array}{l}0.020 \\
0.0200 \\
0.0200 \\
0.020\end{array}$ & 0.0005 & 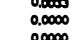 & $\begin{array}{l}0.001 \\
0.0001 \\
00095\end{array}$ \\
\hline & 47 & 0.0000 & sosis & . & 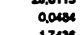 & $\begin{array}{l}0.0000 \\
0.0000 \\
0.00\end{array}$ & 0.0000 & 象 & 0.0000 & 0.00000 & . & 0.0000 \\
\hline & $\infty$ & $\begin{array}{l}0.0756 \\
0.0000\end{array}$ & $\begin{array}{l}0.0000 \\
0.0000\end{array}$ & $\begin{array}{l}0.0000 \\
0.0000\end{array}$ & 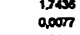 & $\begin{array}{l}0.0000 \\
.00000\end{array}$ & (20.000 & $\begin{array}{l}1700000 \\
0.030\end{array}$ & 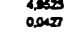 & $\begin{array}{l}0.00000 \\
0,00000\end{array}$ & $\begin{array}{l}0.0000 \\
0.0000\end{array}$ & $\begin{array}{l}0.0000 \\
0.0003\end{array}$ \\
\hline sit & $\begin{array}{l}\text { so } \\
\text { s1 }\end{array}$ & $\begin{array}{l}200000 \\
0.0000\end{array}$ & $\begin{array}{l}0.0000 \\
0.0000\end{array}$ & $\begin{array}{l}0.0000 \\
0.0000 \\
0.00\end{array}$ & $\begin{array}{l}0.0012 \\
0.0200 \\
0.00\end{array}$ & $\begin{array}{l}0.00000 \\
0.0000\end{array}$ & $\begin{array}{l}0.2003 \\
0.0000\end{array}$ & $\begin{array}{l}0.0000 \\
0.00000 \\
0.00\end{array}$ & $\begin{array}{l}0.07090 \\
0.00000 \\
0.00\end{array}$ & $\begin{array}{l}0.0000 \\
13.79010\end{array}$ & $\begin{array}{l}0.0000 \\
0.0000 \\
0.000\end{array}$ & $\begin{array}{l}0.0001 \\
0,0074 \\
0.074\end{array}$ \\
\hline 52 & 52 & $\begin{array}{l}0.0000 \\
0.0000 \\
0.000\end{array}$ & $\begin{array}{l}0.0000 \\
0.0000\end{array}$ & $\begin{array}{l}0.0000 \\
0.0000 \\
0.00\end{array}$ & $\begin{array}{l}0.0111 \\
0.0145\end{array}$ & $\begin{array}{l}0.00000 \\
0.0000\end{array}$ & $\begin{array}{l}0.0000 \\
0.00000\end{array}$ & $\begin{array}{l}0.0000 \\
0.0000 \\
0.000\end{array}$ & $\begin{array}{l}0.0000 \\
0.0000\end{array}$ & $\begin{array}{l}0.00000 \\
0.0000\end{array}$ & $\begin{array}{l}0.0000 \\
0.0000\end{array}$ & 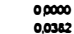 \\
\hline 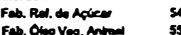 & $\begin{array}{l}\text { st } \\
\text { ss }\end{array}$ & $\begin{array}{l}00000 \\
0.000\end{array}$ & 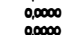 & $\begin{array}{l}0.0000 \\
0.000 \\
0.000\end{array}$ & 0 & $\begin{array}{l}0.0000 \\
0.000\end{array}$ & $\begin{array}{l}0.0000 \\
0.000\end{array}$ & $\begin{array}{l}0.0000 \\
0.000\end{array}$ & $\begin{array}{l}0.0000 \\
0.050 \\
0.050\end{array}$ & $\begin{array}{l}0.0000 \\
0.000\end{array}$ & $\begin{array}{l}0.0000 \\
0.000 \\
0.000\end{array}$ & 我 \\
\hline & 58 & 0.0000 & $\begin{array}{l}0.0000 \\
0.000\end{array}$ & . 00000 & 0.0570 & 0.0000 & ..0000 & 0.0000 & 0.0000 & 0.3012 & $\begin{array}{l}0.0000 \\
0.000\end{array}$ & 然 0.0014 \\
\hline 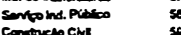 & 58 & 年 & 然 & 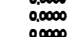 & 然 00000 & .0.0000 & ..0000 & $\begin{array}{l}0.0000 \\
0.0000 \\
0.000\end{array}$ & $\begin{array}{l}0.0000 \\
0.000\end{array}$ & 0.0000 & . 0.0000 & $\begin{array}{l}0.0013 \\
0.0000 \\
0.000\end{array}$ \\
\hline & $\infty$ & 0,0000 & 0.0000 & $\begin{array}{l}0.0000 \\
0.0000\end{array}$ & 年 & $\begin{array}{l}0.00000 \\
0.0000\end{array}$ & $\begin{array}{l}0.00000 \\
0.0000\end{array}$ & $\begin{array}{l}20000 \\
0.0000 \\
0.000\end{array}$ & $\begin{array}{l}0.0000 \\
0.0000 \\
0.000\end{array}$ & $\begin{array}{l}0.00000 \\
0.0000\end{array}$ & $\begin{array}{l}0.0000 \\
0.0000\end{array}$ & $\begin{array}{l}0.0000 \\
0.0000 \\
0.000\end{array}$ \\
\hline & 62 & $a, 0$ & 0.0000 & $\begin{array}{l}0.0000 \\
0.0000\end{array}$ & $\begin{array}{l}0.0000 \\
0.0000 \\
0.000\end{array}$ & $\begin{array}{l}0.0000 \\
0.0000 \\
0.000\end{array}$ & $\begin{array}{l}0.0000 \\
0.0000 \\
0.000\end{array}$ & $\begin{array}{l}0.0000 \\
0.0000 \\
0.000\end{array}$ & 0.00000 & $\begin{array}{l}0.00000 \\
0.0000\end{array}$ & $\infty 0$ & $\begin{array}{l}0,0000 \\
0,0000 \\
0.000\end{array}$ \\
\hline 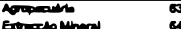 & 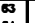 & & 0 & 0.0000 & $\mathrm{com}$ & 0.00051 & 年. & 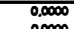 & 0.1010 & 02285 & & 0,00000 \\
\hline & es & 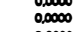 & 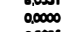 & 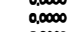 & 垔 0.00000 & $\begin{array}{l}0.00200 \\
.0000\end{array}$ & $\begin{array}{l}0.01038 \\
0.0000\end{array}$ & 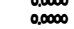 & 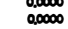 & 0 & $\infty$ & $\begin{array}{l}0.0000 \\
0.0000 \\
0.00\end{array}$ \\
\hline 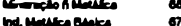 & & $\begin{array}{l}0.00000 \\
0.00010\end{array}$ & 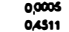 & 年 00000 & 0.0014 & 0.0000 & 0.0000 & 0.0000 & 0.0000 & $\mathrm{mp}$ & 0.0000 & \\
\hline & & 0.000 & 00000 & $\begin{array}{l}0.0000 \\
0.000\end{array}$ & 0.0000 & 0 & - & 0.0000 & 0.0000 & 0 & 0.0006 & 年 \\
\hline (t) & ${ }_{70}^{\infty}$ & 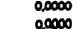 & $\begin{array}{l}0.0000 \\
0.0000 \\
0.000\end{array}$ & $\begin{array}{l}0.0000 \\
0.0000\end{array}$ & 我 0.0000 & $\begin{array}{l}0.00017 \\
0,00000\end{array}$ & $\begin{array}{l}0.00000 \\
0.0000\end{array}$ & 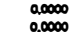 & $\begin{array}{l}0.0000 \\
0.0000 \\
0.00\end{array}$ & $\begin{array}{l}0.0000 \\
0.0000\end{array}$ & 年 00000 & $\begin{array}{l}0.0000 \\
0.0000 \\
0.00\end{array}$ \\
\hline & & 0.0000 & 0.0000 & a. & 0,0000 & 0.0000 & 0.0000 & 0,0000 & 0.0000 & 0.0000 & 0.0000 & 0.0000 \\
\hline 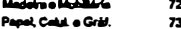 & 72 & $\begin{array}{l}0.00000 \\
0.00020\end{array}$ & $\begin{array}{l}0.0000 \\
0.00010\end{array}$ & $\begin{array}{l}0.0000 \\
0.0149\end{array}$ & $\begin{array}{l}0.0000 \\
2000\end{array}$ & $\begin{array}{l}0.00000 \\
0,1403\end{array}$ & $\begin{array}{l}0.0000 \\
0.0072\end{array}$ & $\begin{array}{l}0.0000 \\
0.1875 \\
0.185\end{array}$ & $\begin{array}{l}0.0000 \\
0.0018 \\
0.016\end{array}$ & $\begin{array}{l}0.00000 \\
0.0616\end{array}$ & $\begin{array}{l}0.0000 \\
0.0055 \\
0.05\end{array}$ & 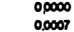 \\
\hline & 74 & 0.0106 & 0.0001 & a. & 0.0004 & 0.0431 & 年 & 象 & 0.0000 & 0 & 0.0000 & 0.0000 \\
\hline$\infty<$ & 78 & $\begin{array}{l}0.00000 \\
0.000\end{array}$ & $\begin{array}{l}0.1228 \\
0.1248\end{array}$ & $\begin{array}{l}0.000 \\
0.0719 \\
0.00\end{array}$ & $\begin{array}{l}0.501 \\
0.02030 \\
0.001\end{array}$ & $\begin{array}{l}0.0006 \\
0.0002\end{array}$ & 0.0 & $\begin{array}{l}0.0003 \\
0.0000 \\
0.003\end{array}$ & $\begin{array}{l}0.01103 \\
0.0000\end{array}$ & $\begin{array}{l}0.0001000000 \\
0.0000\end{array}$ & $\begin{array}{l}0.0001 \\
0.0000 \\
0.000\end{array}$ & $\begin{array}{l}0.0002 \\
0.0000\end{array}$ \\
\hline & 77 & 0,0013 & 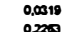 & 年 & $0.50=1$ & 0.1053 & 0.1183 & o.0005 & $\mathrm{m}$ & 0.0002 & 0.0000 & 0.0000 \\
\hline 78 & 79 & $\begin{array}{l}0.0000606 \\
0.0186\end{array}$ & $\begin{array}{l}0.0000 \\
0.000\end{array}$ & $\begin{array}{l}0.0000 \\
0.000\end{array}$ & $\begin{array}{l}\text { o. } \\
0.0012 \\
0.048\end{array}$ & $\begin{array}{l}0.00000 \\
0.0000 \\
0\end{array}$ & $\begin{array}{l}0.00000 \\
0.9021\end{array}$ & 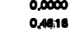 & $\begin{array}{l}\begin{array}{l}0.0000 \\
0.1100\end{array} \\
0.00\end{array}$ & $\begin{array}{l}0.00000 \\
0.0000\end{array}$ & $\begin{array}{l}0.0000 \\
0.0000\end{array}$ & $\begin{array}{l}0.0000 \\
0.0000\end{array}$ \\
\hline coum & & $\begin{array}{l}0.00000 \\
0.0000\end{array}$ & $\begin{array}{l}0.00000 \\
0,0000\end{array}$ & $\begin{array}{l}0.0000 \\
0.0000 \\
0.000\end{array}$ & $\begin{array}{l}0.0004 \\
0.0001\end{array}$ & $\begin{array}{l}0.00000 \\
0.0000\end{array}$ & $\begin{array}{l}0.0000 \\
0.015\end{array}$ & $\begin{array}{l}0.0194 \\
0.0144\end{array}$ & : & $\begin{array}{l}0.00000 \\
0.0000\end{array}$ & $\begin{array}{l}0.0005 \\
0.0000 \\
0.000\end{array}$ & \\
\hline 82 & .2 & $\begin{array}{l}0.00000 \\
0.00000\end{array}$ & $\begin{array}{l}0.0000 \\
0.0000\end{array}$ & $\begin{array}{l}0.0000 \\
0.0000 \\
0.00\end{array}$ & $\begin{array}{l}0.0180 \\
0.0180 \\
0.000\end{array}$ & $\begin{array}{l}0.00000 \\
0.0000\end{array}$ & 0.0 .0 & 0 & 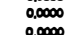 & 0.0000 & $\begin{array}{l}0.0000 \\
0.0000 \\
0.000\end{array}$ & 100 \\
\hline 8 & 34 & 0.0000 & 0.0000 & 0.0000 & one & 0.00000 & 0.00000 & 0.0000 & 然 & 0.00000 & 0.0000 & 0.1211 \\
\hline שהחה & & $\begin{array}{l}0.00000 \\
0.00000\end{array}$ & $\begin{array}{l}0.0000 \\
0.0000\end{array}$ & $\begin{array}{l}0.000 \\
0.0000 \\
0.000\end{array}$ & 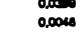 & $\begin{array}{l}0.00000 \\
0.0000\end{array}$ & $\begin{array}{l}0.00000 \\
0.0000\end{array}$ & $\begin{array}{l}0.0000 \\
0.0000 \\
0.000\end{array}$ & $\begin{array}{l}0.0000 \\
0.0000 \\
0.000\end{array}$ & $\begin{array}{l}0.00000 \\
0.0000\end{array}$ & $\begin{array}{l}0.0000 \\
0.0000 \\
0.000\end{array}$ & $\begin{array}{l}0.0000 \\
0.0000 \\
0.000\end{array}$ \\
\hline 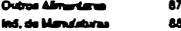 & 87 & $\begin{array}{l}0.00000 \\
0.0000\end{array}$ & $\begin{array}{l}0.0000 \\
0.0000\end{array}$ & 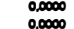 & 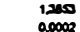 & 0.0 & $\begin{array}{l}0.00000 \\
0.0000\end{array}$ & $\begin{array}{l}0.0000 \\
0.0000 \\
0.000\end{array}$ & $\begin{array}{l}0.0001 \\
0.0000\end{array}$ & os & $\begin{array}{l}0.0000 \\
0.0000 \\
0.00\end{array}$ & \\
\hline 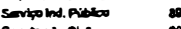 & 20 & 0.0000 & 0.0000 & 年 & 0.0000 & 0.0000 & 0.0000 & 0.0000 & 0.0000 & 0.0 & 0.0000 & 0.0000 \\
\hline & & $\begin{array}{l}0.0000 \\
0.0000\end{array}$ & $\begin{array}{l}0.0000 \\
0.0000\end{array}$ & $\begin{array}{l}0.0000 \\
0.0000\end{array}$ & $\begin{array}{l}0.0000 \\
0.0000 \\
0.00\end{array}$ & $\begin{array}{l}0.0000 \\
0.0000 \\
0.00\end{array}$ & $\begin{array}{l}0.00000 \\
0.00000\end{array}$ & $\begin{array}{l}0.0000 \\
0.0000 \\
0.00\end{array}$ & $\begin{array}{l}0.0000 \\
0.0000\end{array}$ & $\begin{array}{l}0.00000 \\
0,0000\end{array}$ & 然 00000 & 我 000000 \\
\hline & & & 0.000 & 0.0000 & $\infty$ & & & $m$ & & & w & \\
\hline & $\infty$ & 0. & 0.0000 & 0.0000 & -00 & 0.000 & 0.0 & 00000 & & 0.0 & 0.0 & 0.0000 \\
\hline & s. & & $\begin{array}{l}0.0100 \\
0.1010\end{array}$ & $\begin{array}{l}0.0000 \\
0.000 \\
0.00\end{array}$ & s. & $0 a$ & & 00000 & & & & \\
\hline & & & 0.0000 & 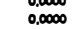 & o. & 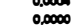 & 0 & 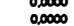 & & & & \\
\hline & & $.0 m$ & 0.0057 & 0.0000 & 1000 & 政 & 0.00000 & 0.0000 & 急 & & 0.0000 & \\
\hline & & $\begin{array}{l}0.0 \\
0.01\end{array}$ & $\begin{array}{l}0.0000 \\
0.0000 \\
0.000\end{array}$ & $\begin{array}{l}0.0000 \\
0.0000\end{array}$ & 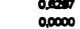 & $\begin{array}{l}0.00000 \\
0.0004\end{array}$ & $\infty$ & $\begin{array}{l}0.0000 \\
0.0000 \\
0.000\end{array}$ & $\begin{array}{l}0.0000 \\
0.0000 \\
0.00\end{array}$ & 0.0000 & & $\begin{array}{l}0.0000 \\
0.0000\end{array}$ \\
\hline & 100 & & 0.0000 & 年 & 0.0000 & o. $0.002 s$ & 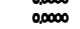 & 年 & & 年, 0000 & & $\begin{array}{l}0.0000 \\
0.0000 \\
0.00\end{array}$ \\
\hline & & & 0.0000 & 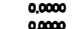 & 0.0000 & 0.0 & 0.0 & 0.0000 & 0.0000 & 0.0000 & & \\
\hline & 100 & & $\begin{array}{l}0.0000 \\
0.0000\end{array}$ & $\begin{array}{l}0.0000 \\
0.0000\end{array}$ & 央 & & $\begin{array}{l}0.00000 \\
00000\end{array}$ & 我 & 0 & $\begin{array}{l}0.0000 \\
0.0000 \\
0.000\end{array}$ & . & \\
\hline $1.0 \mathrm{ard}$ & 104 & 0.0 & 0.0073 & . & 年 & 0.1 & 0.00000 & 0.1000 & 0.0000 & 0.040 & 0.0000 & 0.0000 \\
\hline & & . & $\begin{array}{l}0.0008 \\
0.0228\end{array}$ & $\begin{array}{l}0.0000 \\
0.0056\end{array}$ & $\begin{array}{l}0.1215 \\
1.020\end{array}$ & & 0.0050 & $\begin{array}{l}0.0000 \\
0.0002 \\
0.02\end{array}$ & $\begin{array}{l}0.0000 \\
0.0014 \\
0.00\end{array}$ & $\begin{array}{l}0.0000 \\
0.0000\end{array}$ & 0.0001 & \\
\hline & 107 & a.0000 & 0.0000 & 0.0000 & ט. & & ow & 000000 & and & 0.0 & 0.0000 & \\
\hline & 100 & 0.3 & 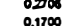 & 等 & 年 & ه & $\begin{array}{l}1.0130 \\
0.0000\end{array}$ & 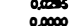 & 0. & & & \\
\hline & 政 & . & 年, 00000 & 0.0000 & 年 & 0,00000 & spen & 3.200 & 0,4 & 0.0000 & 0.0000 & $\begin{array}{l}0.0000 \\
0.0000 \\
0.00\end{array}$ \\
\hline & & 0.0000 & 0.0000 & 0.0000 & 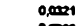 & 0.0 & 0.0000 & 1,0006 & 0. & 0.0000 & م & 0.0 \\
\hline & 1 & & 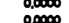 & 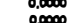 & 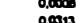 & 08 & 0.01400 & 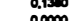 & & & & \\
\hline & 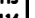 & & & & & & & & & & & \\
\hline & 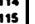 & 0 & 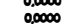 & 0 & 1,570 & 0.0 & 我, & 我00000 & 0.0 & $\begin{array}{l}0.0000 \\
0.000\end{array}$ & 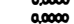 & \\
\hline & & & 00 & 0,0000 & 0.0 & 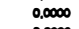 & 00000 & 0.0000 & 0. & 0.0000 & 0.0000 & $\infty$ \\
\hline & & & 0.00000 & 0.00000 & 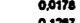 & 0.00000 & & 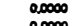 & & 0.0000 & $\infty$ & 0.0000 \\
\hline & & & 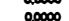 & 0 & 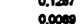 & & & & & & & 0.0070 \\
\hline & 120 & & 0,0000 & 0.0000 & 0.0000 & & 0,00000 & 0.0000 & & 0.0000 & 0.0000 & $\begin{array}{l}0.00000 \\
0.00000\end{array}$ \\
\hline & 12 & 0.0 & 0.0000 & 0.0000 & 0.0000 & 0.0 & 0.0000 & 0.0000 & 0.0000 & 0.0000 & & o. \\
\hline & 128 & & 0.0 & 0.00000 & $\infty \infty_{\infty}^{\infty}$ & & & & & & & \\
\hline & 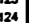 & & 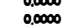 & 0.0000 & & . & 0.0000 & & & 央 & $\infty_{\infty}^{\infty}$ & \\
\hline$\frac{12}{12}$ & 125 & 00,0001 & 40.7190 & Doven & & & & & & & & \\
\hline & 127 & $\begin{array}{l}25000 \\
\pi 9000\end{array}$ & 150.0128 & $\begin{array}{l}20.05012 \\
25842\end{array}$ & $\begin{array}{l}13.3577000 \\
750.1700\end{array}$ & 79.050 & 97.2113 & 0.6 & $\begin{array}{l}12115 \\
20,0000\end{array}$ & $\begin{array}{l}2,0,071 \\
\text { 3is40 }\end{array}$ & $\begin{array}{l}0.1100 \\
0.1305\end{array}$ & $\begin{array}{l}0.5807 \\
5.30209\end{array}$ \\
\hline 12 & 100 & 207,0000 & 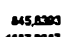 & 24178280 & 100.00009 & 7138780 & 770000015 & 1101 1A370 & 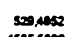 & 2050000 & 年 & 60.6.621 \\
\hline & & 2055202 & 1007.9800 & 02020.519 & $C 000.2217$ & 1400.0172 & 2007.05000 & 3012.248 & & A753:8108 & & 1060.5916 \\
\hline
\end{tabular}




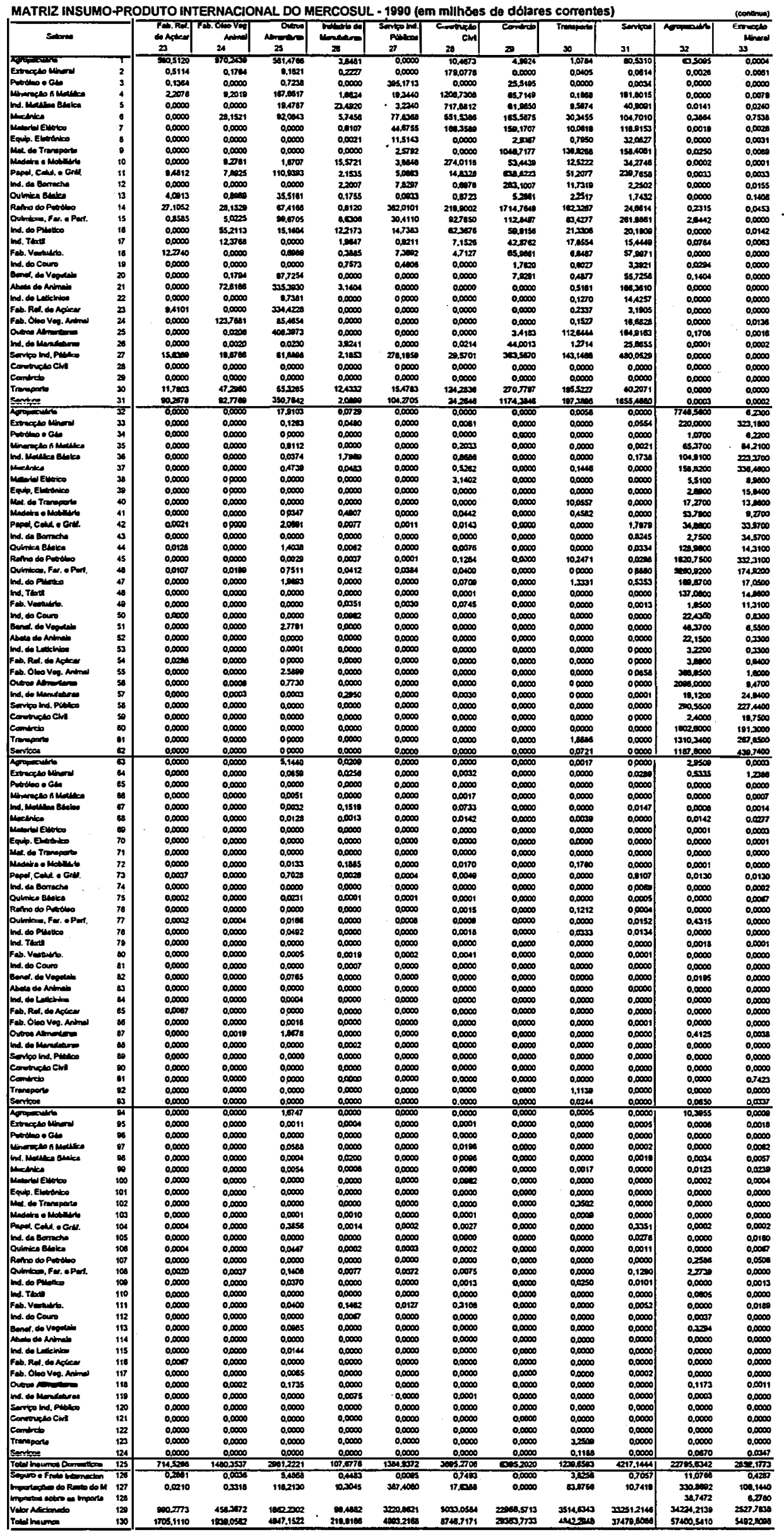




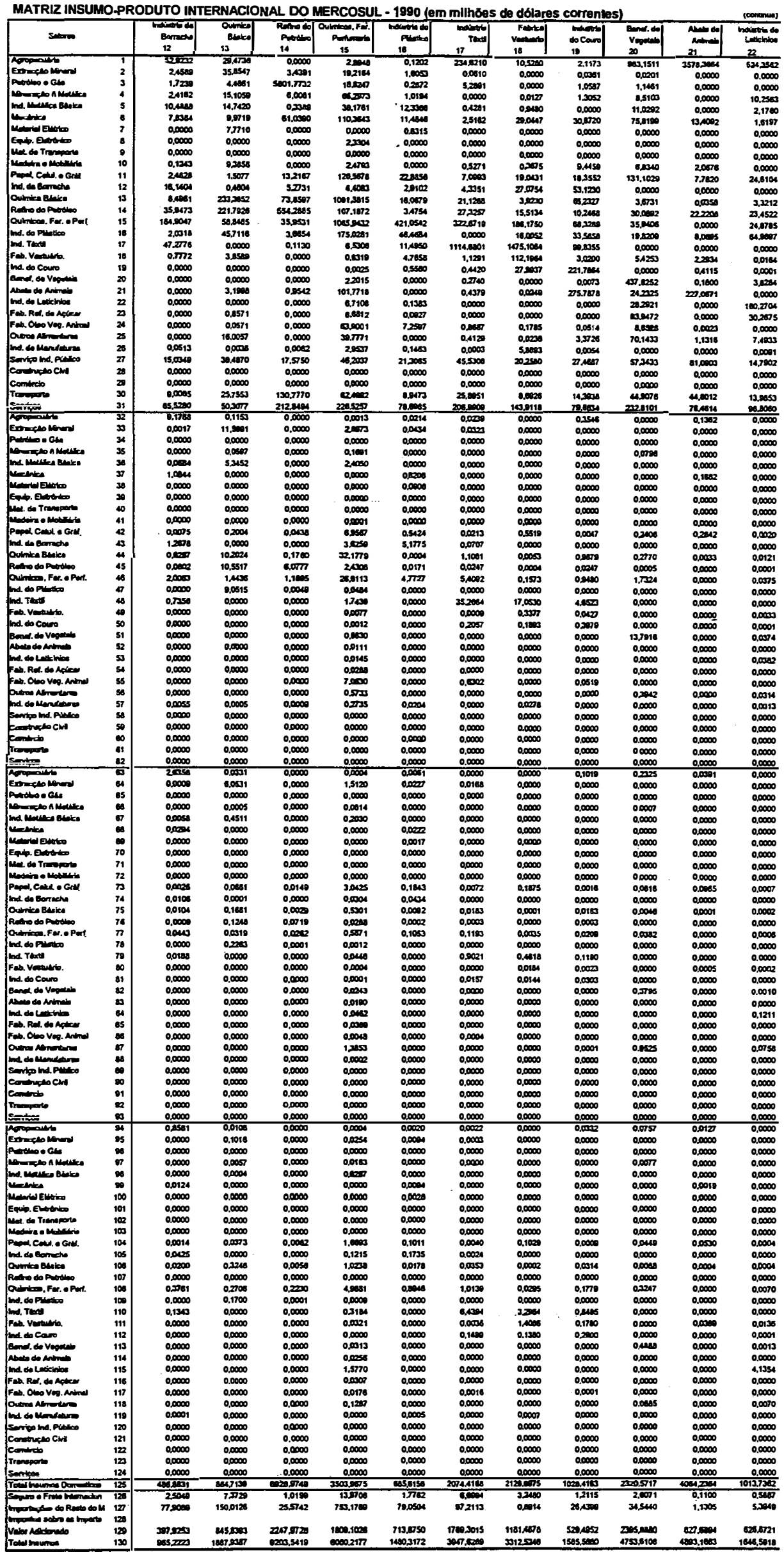









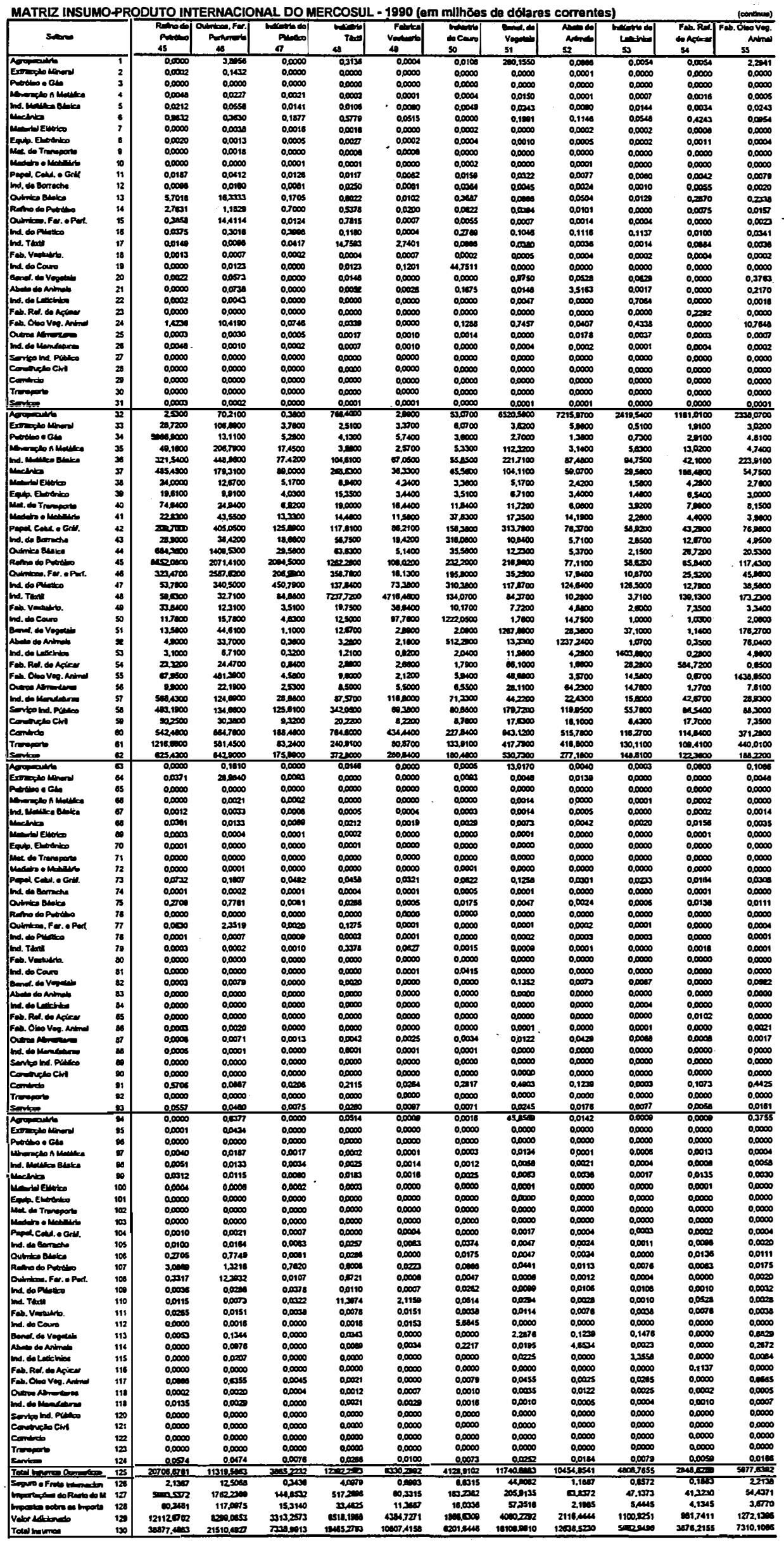




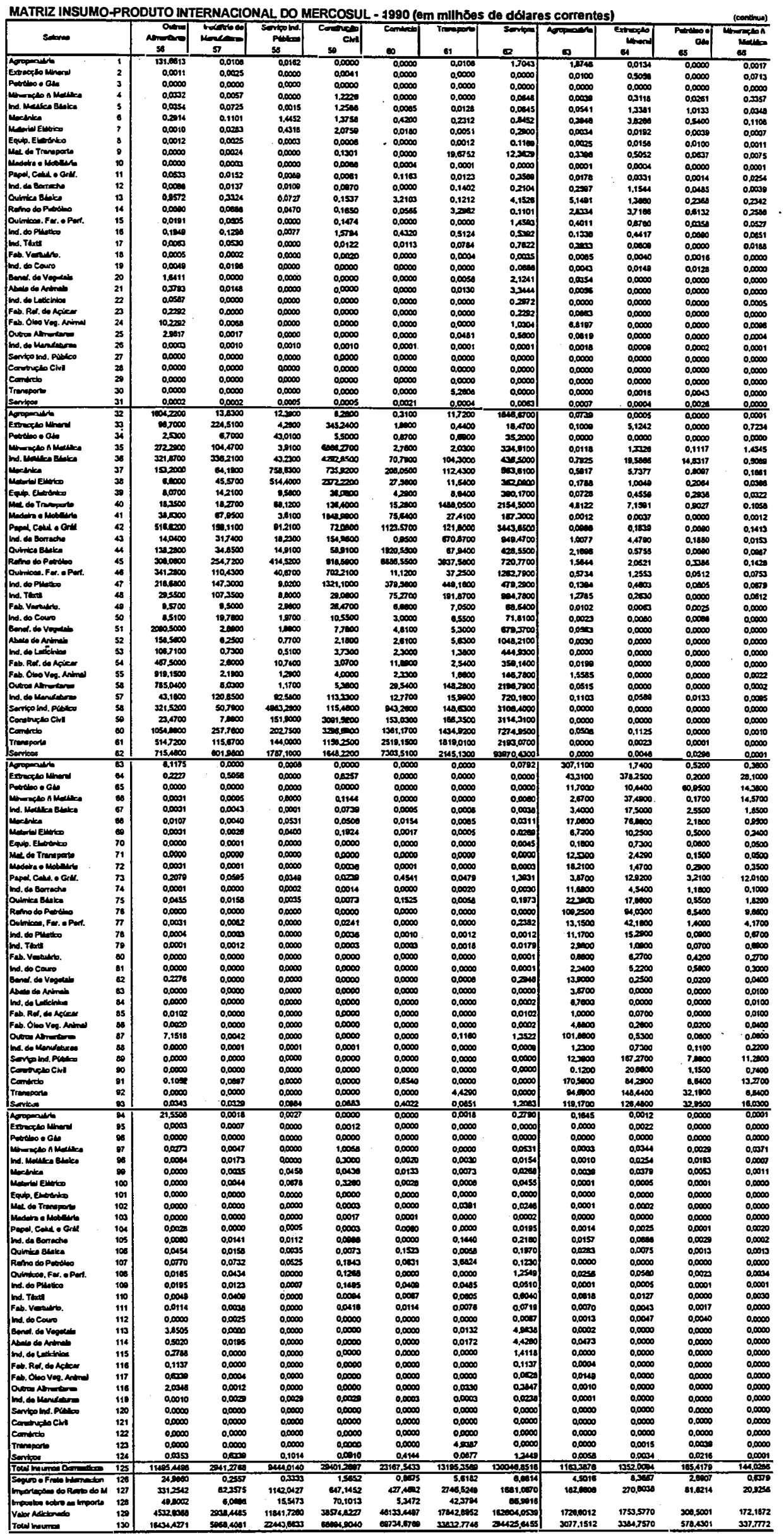




\begin{tabular}{|c|c|c|c|c|c|c|c|c|c|c|c|}
\hline stomen & not & and & 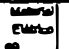 & $\Rightarrow$ & (1) & 10 & 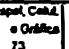 & 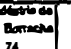 & | & & 隹 \\
\hline החקלמה & & 0.0050 & & & & & & & & & \\
\hline 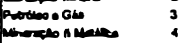 & $\begin{array}{l}0.0000 \\
0.1358\end{array}$ & $\begin{array}{l}0.0000 \\
0.00000 \\
0.0005\end{array}$ & $\begin{array}{l}0.0000 \\
0.0752 \\
0.0752\end{array}$ & 然 & $\begin{array}{l}0.000 \\
0.0000 \\
0.0000\end{array}$ & 年 0.0000 & 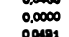 & 然 0000000 & . & $\begin{array}{l}0.0000 \\
0.0000\end{array}$ & $\begin{array}{l}0.000 \\
0.0000 \\
0.000\end{array}$ \\
\hline 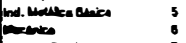 & $\begin{array}{l}12124 \\
0.27200\end{array}$ & $\begin{array}{l}3.2074 \\
0.04073\end{array}$ & 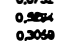 & 势 & 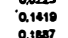 & 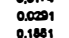 & $\begin{array}{l}0.1000 \\
0.008 \\
0.000\end{array}$ & 然 & o. & 0.0078 & 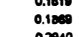 \\
\hline 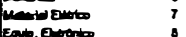 & . & 0.0000 & .00281 & 0.0001 & 0.00025 & $\begin{array}{l}0.0000 \\
0.0000\end{array}$ & 0.0005 & 0.0015 & 0.0000 & o.,0011 & $\begin{array}{l}0.0200 \\
0.0012\end{array}$ \\
\hline 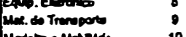 & $\begin{array}{l}0.000 \\
0.0101\end{array}$ & $\begin{array}{l}0.0018 \\
0.0171\end{array}$ & $\begin{array}{l}0.0002 \\
0.00010\end{array}$ & 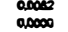 & $\begin{array}{l}.0 .0000 \\
2.5174\end{array}$ & $\begin{array}{l}0.0010 \\
0.0012\end{array}$ & $\begin{array}{l}0.0050 \\
0.0001 \\
0.000\end{array}$ & $\begin{array}{l}0.0000 \\
0.0070\end{array}$ & $\begin{array}{l}0.00000 \\
0.00000\end{array}$ & $\begin{array}{l}0.0008 \\
0.0001\end{array}$ & . \\
\hline w. onseles. & $\begin{array}{l}0.0000 \\
0.056 \\
0.056\end{array}$ & $\begin{array}{l}0.0000 \\
0.05000\end{array}$ & $\begin{array}{l}0.0001 \\
0.0010\end{array}$ & $\begin{array}{l}0.0000 \\
0.0014 \\
\end{array}$ & 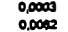 & $\begin{array}{l}0.0113 \\
0.0000\end{array}$ & $\begin{array}{l}0.0001 \\
23100\end{array}$ & $\begin{array}{l}0.0000 \\
0.0015 \\
0.020\end{array}$ & $\begin{array}{l}0.00000 \\
0.0043\end{array}$ & $\begin{array}{l}0.0000 \\
0.0057\end{array}$ & - \\
\hline $\begin{array}{l}12 \\
13\end{array}$ & 然 & $\begin{array}{l}0.0000 \\
0 . \$ 123\end{array}$ & 0.0141 & 然 & 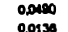 & 0 & 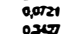 & 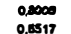 & 0.0000 & 0.0051 & 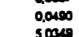 \\
\hline 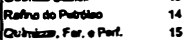 & 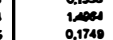 & $\begin{array}{l}0250 \\
0.1742\end{array}$ & 年 & 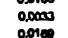 & 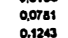 & 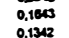 & 年 & $\begin{array}{l}0.051 \\
0.0051 \\
0.0060\end{array}$ & $\begin{array}{l}0.01100 \\
0.2000\end{array}$ & $\begin{array}{l}\text { sasel } \\
\text { osstor }\end{array}$ & 年 \\
\hline $\begin{array}{l}16 \\
17\end{array}$ & $\begin{array}{l}0.072 \\
0.00075\end{array}$ & $\begin{array}{l}0.0071 \\
0.00000 \\
0.000\end{array}$ & 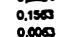 & 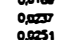 & 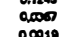 & 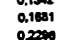 & inso & 然.11113 & $\begin{array}{l}0.00313 \\
0.0100\end{array}$ & 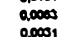 & $\begin{array}{l}37506 \\
0.2503 \\
0.2003\end{array}$ \\
\hline $\begin{array}{l}11 \\
18 \\
19\end{array}$ & $\begin{array}{l}0.070 \\
0.000 \\
0.0000\end{array}$ & 然 0.0016 & 年 & $\begin{array}{l}0.000 \\
0.0000 \\
0.000\end{array}$ & $\begin{array}{l}0.0000 \\
0,0,000 \\
0.000\end{array}$ & 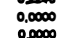 & 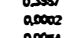 & 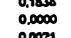 & 0 & 0.0000 & sock \\
\hline 20 & $\begin{array}{l}0.0000 \\
0.0000 \\
0.000\end{array}$ & $\begin{array}{l}0.0000 \\
0.0000\end{array}$ & $\begin{array}{l}0.000110 \\
0.0110\end{array}$ & $\begin{array}{l}0.00000 \\
0.0000 \\
0.00\end{array}$ & $\begin{array}{l}0.0000 \\
0.0000\end{array}$ & $\begin{array}{l}0.0000 \\
0.00000\end{array}$ & 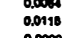 & $\begin{array}{l}0.021 \\
0.0000\end{array}$ & $\begin{array}{l}0.000000 \\
0.0000\end{array}$ & 年 0.00000 & $\begin{array}{l}0.0005 \\
0.0000\end{array}$ \\
\hline 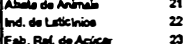 & $\begin{array}{l}0.000 \\
0.000 \\
0.000 \\
0,000\end{array}$ & $\begin{array}{l}0.014 \\
0.0000 \\
0,0000\end{array}$ & $\begin{array}{l}0.0000 \\
0.0000 \\
0.0000\end{array}$ & $\begin{array}{l}0.0000 \\
0.0000 \\
0.0000\end{array}$ & $\begin{array}{l}0.0000 \\
0.0000 \\
0.00000\end{array}$ & $\begin{array}{l}0.0000 \\
0.0000 \\
0.0000\end{array}$ & $\begin{array}{l}0.0000 \\
0.0000 \\
0.0000 \\
0.0000\end{array}$ & $\begin{array}{l}0.0000 \\
0.0000 \\
0.0000\end{array}$ & $\begin{array}{l}0.0000 \\
0.00200 \\
0.02000\end{array}$ & $\begin{array}{l}0.0000 \\
0.0000 \\
0.0000\end{array}$ & $\begin{array}{l}0.031 \\
0.002 \\
0.0022 \\
0.0000\end{array}$ \\
\hline 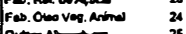 & 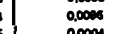 & 我, 000000 & 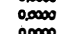 & cass & 0.0000 & 0.0000 & 0,0000 & 0.15077 & 0.00011 & .0.094 & seen \\
\hline סחים & 0.0000 & 0.0024 & 0.0000 & 0.0000 & 0.0001 & 0.00000 & 0.0051 & 0.0006 & 0.0001 & 0.0001 & 000 \\
\hline 管 & $\begin{array}{l}0.0000 \\
0.0000 \\
0.000\end{array}$ & $\begin{array}{l}0.0000 \\
0.0000\end{array}$ & $\begin{array}{l}0.0000 \\
0.0000 \\
0.00\end{array}$ & $\begin{array}{l}0.0000 \\
0.0000\end{array}$ & $\begin{array}{l}0.0000 \\
0.0000\end{array}$ & $\begin{array}{l}0.00000 \\
0.0000 \\
0\end{array}$ & $\begin{array}{l}0.0000 \\
0.0000\end{array}$ & $\begin{array}{l}0.0000 \\
0.0000\end{array}$ & $\begin{array}{l}0.00000 \\
0.0000\end{array}$ & $\begin{array}{l}0.0000 \\
0.0000 \\
0.000\end{array}$ & . \\
\hline 20 & $\begin{array}{l}0.0000 \\
0.0000 \\
0.000\end{array}$ & $\begin{array}{l}0.0000 \\
0.0011\end{array}$ & $\begin{array}{l}0.0000 \\
0.00000 \\
0.000\end{array}$ & $\begin{array}{l}0.0000 \\
0.00000 \\
0.000\end{array}$ & $\begin{array}{l}0.0000 \\
0.0000\end{array}$ & $\begin{array}{l}0.0000 \\
0.0000\end{array}$ & $\begin{array}{l}0.0000 \\
0.0000\end{array}$ & $\begin{array}{l}0.0000 \\
0.0000\end{array}$ & $\begin{array}{l}0.00000 \\
0.0000\end{array}$ & $\begin{array}{l}0.0000 \\
0.0000 \\
.000\end{array}$ & $\begin{array}{l}0.0000 \\
0.0000\end{array}$ \\
\hline & 0.0001 & $\frac{0.0001}{0.0099}$ & & $\frac{0.0000}{0.0000}$ & 0.0001 & 000 & 0.0002 & & $\infty \infty$ & 0.0000 & 0001 \\
\hline 30 & is,s75 & 0.0505 & 0.0050 & 0.0000 & 0.0000 & 0.00000 & 0 & 0.0005 & 0.1000 & 0.000 & $\infty$ \\
\hline${ }_{35}^{34}$ & $\begin{array}{l}0.0000 \\
0.55001\end{array}$ & $\begin{array}{l}0.0000 \\
0.2702 \\
0.710\end{array}$ & $\begin{array}{l}0.0000 \\
0.2314 \\
0.214\end{array}$ & $\begin{array}{l}0.0000 \\
0.004 \\
0.04\end{array}$ & $\begin{array}{l}0.0000 \\
0.0000 \\
0.000\end{array}$ & $\begin{array}{l}0.0000 \\
0.0745 \\
0.07\end{array}$ & $\begin{array}{l}0.0000 \\
02007\end{array}$ & $\begin{array}{l}0.0000 \\
0.0000\end{array}$ & $\begin{array}{l}0.00000 \\
0.0000\end{array}$ & $\begin{array}{l}0.000 \\
0.1500\end{array}$ & $\begin{array}{l}0.000 \\
.0010\end{array}$ \\
\hline $\begin{array}{l}38 \\
37 \\
37\end{array}$ & 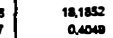 & 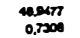 & 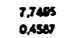 & 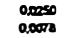 & $2 \begin{array}{l}20771 \\
02000\end{array}$ & 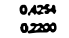 & 年 & 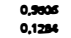 & $\begin{array}{l}0.02538 \\
0.0008\end{array}$ & 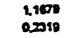 & $\begin{array}{l}2,7301 \\
0.100\end{array}$ \\
\hline 尊8 & 0 & $\begin{array}{l}0.0553 \\
0.0565\end{array}$ & 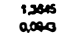 & 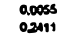 & $\begin{array}{l}0.1006 \\
0.0000\end{array}$ & $\begin{array}{l}0.0152 \\
0.02506\end{array}$ & $\begin{array}{l}0.1000 \\
0.005\end{array}$ & $\begin{array}{l}0.0000 \\
0.0100\end{array}$ & $\begin{array}{l}0.10159 \\
0.0178\end{array}$ & $\begin{array}{l}0.0 .050 \\
0.1122\end{array}$ & $\begin{array}{l}0.0002 \\
.021245\end{array}$ \\
\hline 等 & $\begin{array}{l}0.14202 \\
0.0000 \\
0.00\end{array}$ & 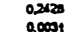 & $\begin{array}{l}0.05000 \\
0.0006\end{array}$ & $\begin{array}{l}0.0000 \\
0.0000 \\
0.000\end{array}$ & 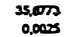 & $\begin{array}{l}0.2284 \\
0.1724\end{array}$ & $\begin{array}{l}0.0000 \\
0.0000 \\
0.00\end{array}$ & $\begin{array}{l}0.1121 \\
0.0000\end{array}$ & $\begin{array}{l}0.0000 \\
0.0000\end{array}$ & 36 & $\begin{array}{l}0.0025 \\
0.0001\end{array}$ \\
\hline m. ocater. & $\begin{array}{l}0.413 \\
0.000 \\
0.013\end{array}$ & $\begin{array}{l}0.3270 \\
0.3246\end{array}$ & $\begin{array}{l}0.1730 \\
0.05016\end{array}$ & $\begin{array}{l}0.0000 \\
0.0002 \\
0.002\end{array}$ & $\begin{array}{l}0.0017 \\
0.1002 \\
0.1002\end{array}$ & $\begin{array}{l}0.22000 \\
0,1011\end{array}$ & $\begin{array}{l}12007 \\
0.728\end{array}$ & Q a 1300 & $\begin{array}{l}0.3572 \\
0.0150\end{array}$ & $\begin{array}{l}0.097 \\
0.00197 \\
0.019\end{array}$ & , 1005 \\
\hline Salos. & 0.0017 & 0.177 & o. 0.05005 & 0.0070 & o.005 & 0.1071 & 0 & 0.216 & $0.70 s 8$ & 00002 & 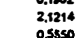 \\
\hline C.opert & 02001 & 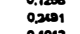 & 然 & 0.00011 & 0.1778 & 0.018 & 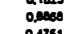 & 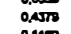 & osers & $8 s$ & 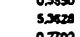 \\
\hline 47 & 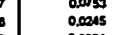 & 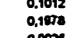 & 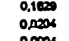 & 等 & 年, 00001 & $\begin{array}{l}0.7122 \\
0.74050\end{array}$ & $\begin{array}{l}0.7131 \\
\text { i.1.158 }\end{array}$ & 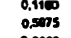 & $\begin{array}{l}0.0008 \\
0.0028\end{array}$ & $\begin{array}{l}0.0102 \\
0.0102\end{array}$ & $\begin{array}{l}0.7202 \\
0.1284\end{array}$ \\
\hline so & $\begin{array}{l}0.0000 \\
0.000\end{array}$ & 0.0000 & $\begin{array}{l}0.0004 \\
0.00000\end{array}$ & 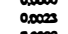 & 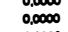 & 年. 0.000 & o., & $\begin{array}{l}0.0011 \\
0.0011\end{array}$ & $\begin{array}{l}0.0011 \\
0.0000\end{array}$ & 等 & $\begin{array}{l}0.0006 \\
0.000\end{array}$ \\
\hline $\begin{array}{l}81 \\
82\end{array}$ & $\begin{array}{l}0.0000 \\
0.0000\end{array}$ & $\begin{array}{l}0.0000 \\
0.0000\end{array}$ & $\begin{array}{l}0.01780 \\
0.00000 \\
0.00\end{array}$ & $\begin{array}{l}0.0000 \\
0.0000 \\
0.000\end{array}$ & $\begin{array}{l}0.0000 \\
0.0000\end{array}$ & $\begin{array}{l}0.0000 \\
0.0000 \\
0.00\end{array}$ & $\begin{array}{l}0.0000 \\
0.0000 \\
0.070\end{array}$ & $\begin{array}{l}0.0000 \\
0.0000\end{array}$ & $\begin{array}{l}0.00000 \\
0.0000\end{array}$ & $\begin{array}{l}0.0000 \\
0.0000\end{array}$ & $\begin{array}{l}0.0000 \\
0.0168\end{array}$ \\
\hline 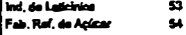 & $\begin{array}{l}0.0000 \\
0.0000 \\
0.00\end{array}$ & $\begin{array}{l}0.0000 \\
0.0000 \\
0.00\end{array}$ & $\begin{array}{l}0.0000 \\
0.0000 \\
0.000\end{array}$ & $\begin{array}{l}0.0000 \\
0.00000\end{array}$ & $\begin{array}{l}0.0000 \\
0.0000 \\
0.000\end{array}$ & $\begin{array}{l}0.0000 \\
0.0000\end{array}$ & $\begin{array}{l}0.0000 \\
0.0000 \\
0.00\end{array}$ & $\begin{array}{l}0.0000 \\
0.0000 \\
0.000\end{array}$ & $\begin{array}{l}0.00000 \\
0.0000\end{array}$ & 0.0000 & $\begin{array}{l}0.0000 \\
0.0100\end{array}$ \\
\hline 55 & 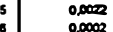 & $\begin{array}{l}0,00000 \\
0.0000\end{array}$ & $\begin{array}{l}0.00000 \\
0.0000\end{array}$ & 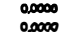 & 0.0000 & $\begin{array}{l}0.0000 \\
0.0000 \\
0.00\end{array}$ & 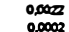 & $\begin{array}{l}0.051 \\
0.05000 \\
0.00\end{array}$ & $\begin{array}{l}0.0020 \\
0.0000\end{array}$ & $\begin{array}{l}0.0000 \\
0.0000 \\
0.000\end{array}$ & 10000 \\
\hline 同 & $\begin{array}{l}0.0110 \\
0.0000 \\
0.000\end{array}$ & 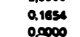 & 我. & 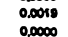 & $\begin{array}{l}0.078 \\
0.0000 \\
0.000\end{array}$ & 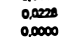 & $\begin{array}{l}0.21000 \\
0.0000\end{array}$ & $\begin{array}{l}.0 .551 \\
0.0000 \\
0\end{array}$ & $\begin{array}{l}00000 \\
0.0000 \\
0.00\end{array}$ & $\begin{array}{l}0.0059 \\
0.000\end{array}$ & 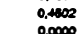 \\
\hline$c 0 \mathrm{Cm}$ & $\begin{array}{l}0.000 \\
0.0100 \\
0.1000\end{array}$ & $\begin{array}{l}0.0000 \\
0.0076\end{array}$ & $\begin{array}{l}0.0000 \\
0.0000 \\
0.000\end{array}$ & $\begin{array}{l}0.0000 \\
0.0000 \\
0.00\end{array}$ & $\begin{array}{l}0.0000 \\
0.0078\end{array}$ & $\begin{array}{l}0.0000 \\
0.0017\end{array}$ & 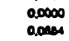 & $\begin{array}{l}0.0000 \\
0.0010\end{array}$ & $\begin{array}{l}0,0000 \\
0.002\end{array}$ & $\begin{array}{l}0.0000 \\
0.0000\end{array}$ & 然 00000 \\
\hline :1 & 0.0000 & $\begin{array}{l}0.0015 \\
0.000\end{array}$ & $\begin{array}{l}0.00000 \\
0.000\end{array}$ & 然 & 然 000000 & $\begin{array}{l}0.0000 \\
0.0005\end{array}$ & $\begin{array}{l}0.0000 \\
0.0017 \\
0.017\end{array}$ & $\begin{array}{l}0.00000 \\
00000\end{array}$ & 0.0000 & 0.0000 & $\begin{array}{l}0.0000 \\
0.0000 \\
0.00\end{array}$ \\
\hline 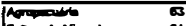 & & & 02000 & 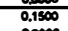 & 0.0000 & 0.000 & $\frac{0.00000}{80000}$ & $\frac{2 x}{12 x}$ & & $\frac{15000}{a s 400}$ & $\frac{0.011}{1017}$ \\
\hline 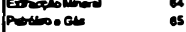 & $\begin{array}{l}0.0000 \\
0.7500\end{array}$ & $\begin{array}{l}7.1 .100 \\
0.8000\end{array}$ & $\begin{array}{l}1,5.5000 \\
0.2800\end{array}$ & $\begin{array}{l}0.0000 \\
0.0100\end{array}$ & $\begin{array}{l}0.300 \\
0.3100\end{array}$ & $\begin{array}{l}0.5000 \\
0.9000\end{array}$ & $\begin{array}{l}4,000 \\
12000\end{array}$ & $\begin{array}{l}0.35 \\
0.00\end{array}$ & 0 & : & $\begin{array}{l}28000 \\
28100\end{array}$ \\
\hline 象 & 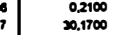 & $\begin{array}{r}325000 \\
14,00000\end{array}$ & 1.100000 & $\begin{array}{l}02000 \\
0.05000\end{array}$ & 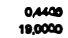 & $\begin{array}{l}0.00500 \\
205000\end{array}$ & $\begin{array}{l}0,000 \\
300000 \\
30000\end{array}$ & $\begin{array}{l}20000 \\
0.70000 \\
0.700\end{array}$ & $\begin{array}{l}0.0000 \\
0.000 \\
0.000\end{array}$ & $\begin{array}{l}0.1000 \\
0.000\end{array}$ & $\begin{array}{l}3.5500 \\
25000 \\
2\end{array}$ \\
\hline$\infty$ & $\begin{array}{l}102000 \\
0.0000\end{array}$ & $\begin{array}{l}10.1000 \\
30000\end{array}$ & $\begin{array}{l}32500 \\
0.0000\end{array}$ & $\begin{array}{l}0.1100 \\
0.22000 \\
0.01\end{array}$ & 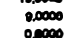 & $\begin{array}{l}1,200 \\
0,000 \\
0,00\end{array}$ & 2000 & 1,700 &  & 51,1000 & $\begin{array}{l}23200 \\
0.30,100\end{array}$ \\
\hline b & 0.0000 & 0.15000 & $\begin{array}{l}0.0100 \\
0.01100\end{array}$ & 0.0000 & 象 & 0.1500 & 0.1850 & $\begin{array}{l}0.05000 \\
0.090\end{array}$ & 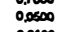 & 0.1500 & $\begin{array}{l}0.1000 \\
0.0000 \\
0.1800\end{array}$ \\
\hline 72 & 年 & 200000 & $\begin{array}{l}0.07000 \\
0.8000\end{array}$ & 我, 00000 & $\begin{array}{l}0.1200 \\
0.1100\end{array}$ & $\begin{array}{r}22,30000 \\
4000\end{array}$ & $\begin{array}{l}0.5000 \\
1.5000\end{array}$ & 0.0000 & & Den & $\begin{array}{l}0.1000 \\
.0000\end{array}$ \\
\hline 8 & $\begin{array}{l}2500 \\
0.01000\end{array}$ & $\begin{array}{l}8.5000 \\
0.5500\end{array}$ & 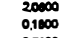 & $\begin{array}{l}0.2000 \\
0.0000\end{array}$ & $\begin{array}{l}20000 \\
0.7200\end{array}$ & $\begin{array}{l}35100 \\
02000 \\
0.00\end{array}$ & $\begin{array}{l}1020200 \\
0.2200\end{array}$ & $\begin{array}{l}22000 \\
5>0000\end{array}$ & 0,0 & 0.0500 & 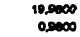 \\
\hline $\begin{array}{l}75 \\
76\end{array}$ & 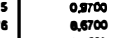 & 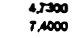 & $\begin{array}{l}0.8100 \\
1.0000\end{array}$ & $\begin{array}{l}0.200 \\
0.1400\end{array}$ & $\begin{array}{l}0,1000 \\
240000\end{array}$ & 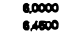 & $\begin{array}{l}13.30000 \\
131,1300\end{array}$ & $\begin{array}{l}2,2000 \\
1,7000\end{array}$ & 4,1700 & $\begin{array}{l}20.0000 \\
21.0000\end{array}$ & $\begin{array}{r}3,4000 \\
109000\end{array}$ \\
\hline${ }_{70}^{n}$ & $\begin{array}{l}0.200 \\
0.3100 \\
0.100\end{array}$ & $\begin{array}{l}820000 \\
24100\end{array}$ & 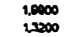 & $\begin{array}{l}0.9100 \\
0.00000\end{array}$ & $\begin{array}{l}2,1100 \\
2.1000\end{array}$ & $\begin{array}{l}15,20000 \\
3,3000\end{array}$ & $\begin{array}{l}1520200 \\
3,77000\end{array}$ & $\begin{array}{r}22400 \\
022000\end{array}$ & 0 & $\begin{array}{l}1382000 \\
0.20000\end{array}$ & $\begin{array}{l}0.7100 \\
10.9000\end{array}$ \\
\hline 79 & $\begin{array}{l}0.500 \\
0.1100\end{array}$ & 象 & $\begin{array}{l}0.3000 \\
0.1000 \\
0.00\end{array}$ & 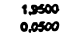 & $\begin{array}{l}2200 \\
03100\end{array}$ & 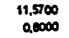 & $\begin{array}{l}4.5000 \\
0.8000\end{array}$ & $\begin{array}{l}3.00 \\
0.12\end{array}$ & 0.050 & 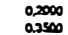 & 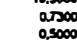 \\
\hline $\begin{array}{:}81 \\
012\end{array}$ & $\begin{array}{l}0.0700 \\
0.5000 \\
0.500\end{array}$ & $\begin{array}{l}0.0500 \\
0.2500\end{array}$ & $\begin{array}{l}0.1000 \\
0.1400\end{array}$ & $\begin{array}{l}0.1250 \\
0.0000 \\
0.00\end{array}$ & $\begin{array}{l}02000 \\
0.00000\end{array}$ & : 100000 & $\begin{array}{l}0.5700 \\
0.000 \\
0.00\end{array}$ & 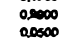 & $\begin{array}{l}0,0000 \\
0.00000 \\
0.000\end{array}$ & $\begin{array}{l}0.1200 \\
0.11000\end{array}$ & $\begin{array}{l}0.5000 \\
0.5000\end{array}$ \\
\hline es & $\begin{array}{l}0.0500 \\
0.2500\end{array}$ & $\begin{array}{l}0.0000 \\
0.00100\end{array}$ & $\begin{array}{l}0.1000 \\
0.00000\end{array}$ & $\begin{array}{l}20000 \\
0.00000 \\
0.000\end{array}$ & $\begin{array}{l}0.000 \\
0.0000 \\
0.000\end{array}$ & $\begin{array}{l}0.1000 \\
0.05000\end{array}$ & $\begin{array}{l}0.2100 \\
0.1000 \\
0.1000\end{array}$ & . & 0.000 & 告 02000 & $\begin{array}{l}0.300 \\
25000 \\
0.2000\end{array}$ \\
\hline (1) & 0.0000 & 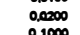 & $\begin{array}{l}0,0000 \\
0.00000 \\
0.000\end{array}$ & $\begin{array}{l}0.000 \\
0.000\end{array}$ & $\begin{array}{l}0.0100 \\
0.0100\end{array}$ & 年 & a.00000 & o. & 00 & 年 & $\begin{array}{l}0.3000 \\
1.0000\end{array}$ \\
\hline & 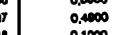 & $\begin{array}{l}0.17700 \\
0.1700\end{array}$ & $\begin{array}{l}0.1500 \\
0.1500\end{array}$ & $\begin{array}{l}0.00000 \\
0.0000 \\
0.000\end{array}$ & $\begin{array}{l}0.000 \\
0.0000 \\
0.0700\end{array}$ & $\begin{array}{l}0.0000 \\
0.1000\end{array}$ & $\begin{array}{l}0.1000 \\
0.5300 \\
0.300\end{array}$ & & 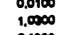 & $\begin{array}{l}0.000 \\
0.0000 \\
0.2000\end{array}$ & $\begin{array}{l}3.000 \\
7,8700\end{array}$ \\
\hline 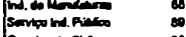 & $\begin{array}{l}0.0000 \\
0.000\end{array}$ & 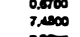 & $\begin{array}{l}0.1700 \\
2.17000 \\
.0000\end{array}$ & $\begin{array}{l}0.0000 \\
0.00000 \\
0.000\end{array}$ & $\begin{array}{l}0.0000 \\
0.0500 \\
0.000\end{array}$ & 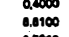 & 年, 200000 & 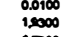 & $\begin{array}{l}0.1000 \\
5,2000\end{array}$ & $\begin{array}{l}0.2000 \\
2,2000\end{array}$ & $\begin{array}{l}0.1300 \\
21200 \\
2\end{array}$ \\
\hline $\mathrm{Sthat}$ & 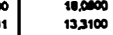 & 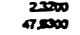 & 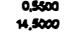 & $\begin{array}{l}0.0000 \\
1.55000\end{array}$ & $\begin{array}{l}0.7000 \\
0100000\end{array}$ & $\begin{array}{l}0.7000 \\
0.0000\end{array}$ & $=2000$ & a.t. & 4,4000 & 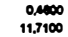 & $\begin{array}{l}1,7300 \\
0.6000\end{array}$ \\
\hline$\infty$ & $\begin{array}{c}5,8700 \\
1301000\end{array}$ & $\begin{array}{r}72000 \\
37,17000\end{array}$ & $\begin{array}{l}215000 \\
1020000\end{array}$ & 1000 & 100 & $\pi$ & $\approx$ & & חרים & 20.2000 & $\begin{array}{l}0.60100 \\
11.5000\end{array}$ \\
\hline & . & 31,7000 & tox & 1.3000 & 10.10000 & 002 & & & 6.3100 & & 1. \\
\hline 95 & 0.0007 & 0.0000 & 0.0000 & & & 0.0000 & 0.0002 & & & & \\
\hline & $\begin{array}{l}0.0000 \\
0.0150\end{array}$ & 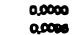 & $\begin{array}{l}0.0000 \\
0.0000\end{array}$ & $\begin{array}{l}0.0000 \\
0.00000\end{array}$ & 0.0000 & $\begin{array}{l}0.0000 \\
0.00010\end{array}$ & $\begin{array}{l}0.0000 \\
0.0054\end{array}$ & o & 0.0 & : & $\begin{array}{l}0.000 \\
0.000 \\
0.078\end{array}$ \\
\hline 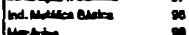 & 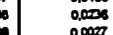 & 0.0000 & $\begin{array}{l}0.0101 \\
0.0000 \\
0.000\end{array}$ & 0.0000 & 0 & 0.0000 & 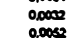 & 0,00 & 0.00 & 然.015 & $\begin{array}{l}0.0176 \\
0.0000 \\
0.000\end{array}$ \\
\hline & 0.0001 & 0.0001 & $\begin{array}{l}0.0000 \\
0.0000\end{array}$ & $\begin{array}{l}0.0001 \\
0.0000\end{array}$ & $\begin{array}{l}0.00010 \\
0.0001\end{array}$ & $\begin{array}{l}0.0010 \\
0.00000\end{array}$ & 0,000 & & & 0.0015 & 0.0000 \\
\hline & 0.0000 & 0.0000 & 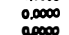 & 0.0000 & $\begin{array}{l}0,0000 \\
0.0000 \\
0\end{array}$ & $\begin{array}{l}0.0000 \\
0.000\end{array}$ & and & & & 0.0000 & $\infty$ \\
\hline 100 & 0.0000 & $\begin{array}{l}0.0000 \\
0.00000\end{array}$ & $\begin{array}{l}0.0000 \\
0.0000\end{array}$ & 0.0000 & - & $\begin{array}{l}0.0000 \\
0.0000\end{array}$ & 年 & 0.0 & $\begin{array}{l}0.0 \\
0.0\end{array}$ & & \\
\hline 104 & $\begin{array}{l}0.00000 \\
0.0015\end{array}$ & $\begin{array}{l}0.0005 \\
0.0052\end{array}$ & $\begin{array}{l}0.0018 \\
0.00000\end{array}$ & $\begin{array}{l}0.0001 \\
0.0000\end{array}$ & $\begin{array}{l}0.0003 \\
0.00000\end{array}$ & $\begin{array}{l}0.0001 \\
0.0017 \\
0.017\end{array}$ & 0.17 & 0.0 & |c.010 & 0.0005 & 0.0051 \\
\hline & 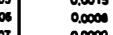 & 年 & 象 & 年.00001 & 0.0001 & 年 & 0.0 & $\begin{array}{l}0.0 \\
0.0\end{array}$ & 0.010 & $\begin{array}{l}0.0000 \\
0.0010\end{array}$ & $\begin{array}{l}0.0000 \\
0.02 \pi\end{array}$ \\
\hline 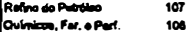 & $\begin{array}{l}0.0000 \\
0.01111\end{array}$ & $\begin{array}{l}0.0000 \\
0.0111\end{array}$ & $\begin{array}{l}0.0000 \\
0.01042\end{array}$ & $\begin{array}{l}0.0000 \\
0.00011\end{array}$ & $\begin{array}{l}a 00000 \\
0.0070\end{array}$ & $\begin{array}{l}0.0000 \\
0.00006\end{array}$ & 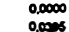 & 0.0 & $\begin{array}{l}0.0000 \\
0.0171\end{array}$ & $\begin{array}{l}0.0000 \\
0.0034\end{array}$ & 070 \\
\hline & 0.001 & 0.0001 & 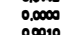 & 我 000000 & 冓 000000 & 0.0000 & 0.0 & 0.0 & & 0.00000 & $\begin{array}{l}0.001 \\
0.0000\end{array}$ \\
\hline & $\begin{array}{l}0.0012 \\
0.0000\end{array}$ & $\begin{array}{l}0.0003 \\
0.0017\end{array}$ & $\begin{array}{l}0.0010 \\
0.0000 \\
0.000\end{array}$ & $\begin{array}{l}0.0006 \\
0.0000\end{array}$ & $\begin{array}{l}20000 \\
0.0000 \\
0.000\end{array}$ & $\begin{array}{l}0.00031 \\
0.00000\end{array}$ & 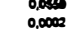 & 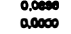 & 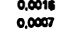 & $\begin{array}{l}0.0005 \\
0.0010\end{array}$ & $\begin{array}{l}0.0001 \\
0.0005\end{array}$ \\
\hline 112 & $\begin{array}{l}0,0000 \\
0.0000\end{array}$ & 0.00 &  & 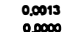 & 0000 & 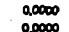 & 0000 & m & . & 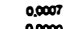 & 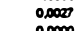 \\
\hline 114 & . 0.000 & $\begin{array}{l}0.000 \\
0.0116\end{array}$ & $\begin{array}{l}0.0001 \\
0.0000 \\
0.00\end{array}$ & 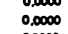 & $\begin{array}{l}0.000 \\
0.0000\end{array}$ & $\begin{array}{l}0.0000 \\
0.00000\end{array}$ & $\begin{array}{l}0.0001 \\
0.0000\end{array}$ & 0.0 & $\begin{array}{l}0.00 \\
0.00\end{array}$ & 0,0000 & $\begin{array}{l}0.0000 \\
0.02068\end{array}$ \\
\hline $\begin{array}{l}115 \\
116\end{array}$ & $\begin{array}{l}0.0000 \\
0.0000\end{array}$ & $\begin{array}{l}0.0000 \\
0.0000 \\
0.0000\end{array}$ & $\begin{array}{l}0.0000 \\
0.0000\end{array}$ & $\begin{array}{l}0.0000 \\
0.0000\end{array}$ & $\begin{array}{l}a, 0000 \\
0.0000\end{array}$ & $\begin{array}{l}000000 \\
0.00000\end{array}$ & $\begin{array}{l}0.0000 \\
0.00000\end{array}$ & $\begin{array}{l}0.0 \\
0 . \infty\end{array}$ & $\begin{array}{l}0.0 \\
0.0\end{array}$ & $\begin{array}{l}0.00000 \\
0.00000\end{array}$ & \\
\hline in & 0.0000 & a.0000 & 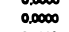 & 年 & 0 & 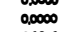 & 00000 & & o. & 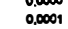 & $\begin{array}{l}0.0004 \\
0.000 \pi\end{array}$ \\
\hline ite & 0,0000 & 0.0000 & 0.0000 & 0.0000 & 0.0000 & 0,0000 & 0.0000 & 00 & 0.0000 & 0.0000 & 0.0013 \\
\hline 110 & 0.0000 & 0.0001 & 0.0000 & 00000 & 0.0000 & 0.00000 & 0.0000 & 0.0 & $0.0 x$ & 0.0000 & 0.0004 \\
\hline 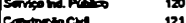 & 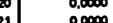 & 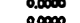 & 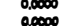 & 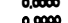 & $\begin{array}{l}0.0000 \\
0.0000\end{array}$ & 00000 & 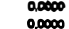 & & m & 必 & \\
\hline & $\infty$ & & : & 0.0000 & & .0.0000 & - & & & & $\begin{array}{l}0.0000 \\
0.00000\end{array}$ \\
\hline 13 & 0.0000 & 0.0010 & 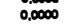 & 0.0000 & & & 0,0000 & $a \infty$ & 0.0 & 0.0000 & 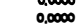 \\
\hline 23. & 000000 & $\frac{0.0004}{270 x}$ & 0.0000 & $\frac{0.0000}{0.000}$ & 00000 & $\frac{0.0 x}{100}$ & 0,0012 & 0.0 & 0 & 0.0016 & 0,0000 \\
\hline 200 & & & $\frac{85}{1}$ & 0.0 & 21.50 & 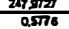 & & & $\frac{\pi}{6 x}$ & 7 & $\frac{20.8681}{4.0400}$ \\
\hline 12 & 720 & 37.0005 & 39,700 & $3 / 12$ & 22005 & 30.0197 & 101.9178 & cososes & $50 x 200$ & 40.0002 & 178008 \\
\hline$\underset{100}{120}$ & 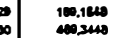 & 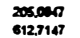 & 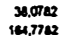 & 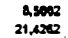 & $\begin{array}{l}20202040 \\
215,13010\end{array}$ & 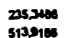 & 年1 20007 & 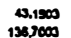 & $\begin{array}{r}81.0014 \\
101201214\end{array}$ & 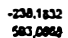 & 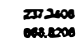 \\
\hline
\end{tabular}


MATRIZ INSUMO+RODUTO INTERNACIONAL DO MERCOSUL - 2990 (em milhöes de dólares cortentes)






\begin{tabular}{|c|c|c|c|c|c|c|c|c|c|c|c|c|}
\hline & 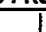 & & & & & & & & & & & 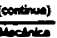 \\
\hline 5 & & & call & & & & an & | & $\infty$ & g & & \\
\hline 6 unerer & & & & & & & 0.0000 & & 0.0000 & & & \\
\hline . $a$ & 3 & $\begin{array}{l}0.0000 \\
0.0000 \\
0.000\end{array}$ & $\begin{array}{l}0.0000 \\
0.0000\end{array}$ & $\begin{array}{l}0.0000 \\
0.0000\end{array}$ & $\begin{array}{l}0.0000 \\
0.0000\end{array}$ & 0.0000 & $\begin{array}{l}0.0000 \\
0.0000\end{array}$ & $\begin{array}{l}0.00000 \\
0.0000\end{array}$ & 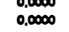 & 0.0000 & 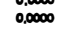 & 0.0000 \\
\hline of & 4 & 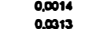 & 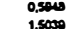 & $\begin{array}{l}0.0000 \\
0.000 \\
0.00\end{array}$ & 0 & 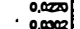 & $\begin{array}{l}0.0000 \\
0.0000 \\
0.00\end{array}$ & $\begin{array}{l}0.0000 \\
0.0000\end{array}$ & $\begin{array}{l}0.0000 \\
0.0000\end{array}$ & $\begin{array}{l}0.2200 \\
0.0001\end{array}$ & 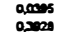 & $\begin{array}{l}0.0015 \\
.0002 \\
1002\end{array}$ \\
\hline & & 0.0725 & 1.3152 & 0.1114 & 0.1901 & 200004 & 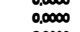 & 0.00000 & 0.0000 & 0.00117 & 0.0000 & 0.1414 \\
\hline$\infty$ & : & $\begin{array}{l}0.00000 \\
0.00000\end{array}$ & $\begin{array}{l}0.05 \pi \\
0.0057\end{array}$ & $\begin{array}{l}0.0018 \\
.00000\end{array}$ & $\begin{array}{l}0.0714 \\
0.0014\end{array}$ & 年 & $\begin{array}{l}0.00000 \\
0.00000\end{array}$ & $\begin{array}{l}0.0000 \\
0.00000\end{array}$ & $\begin{array}{l}0.0000 \\
0.0000\end{array}$ & $\begin{array}{l}0.0000 \\
0.00000\end{array}$ & $\begin{array}{l}0.018 \\
0.0000 \\
0.000\end{array}$ & .0.0000 \\
\hline & i0 & & $\begin{array}{l}0.0005 \\
0.0011\end{array}$ & $\begin{array}{l}0.0000 \\
0.0014\end{array}$ & 12000 &  & $\begin{array}{l}0.2001 \\
0.0000\end{array}$ & $\begin{array}{l}0.0000 \\
0.0000\end{array}$ & $\begin{array}{l}0.0000 \\
0.0000\end{array}$ & $\begin{array}{l}0.0000 \\
0.0000\end{array}$ & 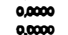 & $\begin{array}{l}0.0000 \\
0.0000 \\
0.00\end{array}$ \\
\hline 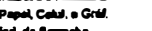 & "1 & 0.0000 & 0.0801 & 12006 & 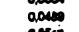 & $0 ., 755$ & 0.0000 & 0.00000 & 0.0000 & 0,00000 & 0.0000 & 0.0000 \\
\hline 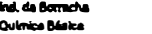 & $\begin{array}{l}12 \\
1 \\
1\end{array}$ & $\begin{array}{l}0.0113 \\
0.00202\end{array}$ & $\begin{array}{l}0.0138 \\
0.02023\end{array}$ & $\begin{array}{l}0.0158 \\
0.0051\end{array}$ & 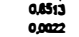 & 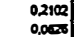 & $\begin{array}{l}0.00000 \\
0.0000\end{array}$ & $\begin{array}{l}0.00000 \\
0.0000\end{array}$ & $\begin{array}{l}0.0000 \\
0.00000\end{array}$ & $\begin{array}{l}0.00000 \\
0.506 x\end{array}$ & $\begin{array}{l}0.0000 \\
0.0000 \\
0.00\end{array}$ & $\begin{array}{l}0.0000 \\
0.02010\end{array}$ \\
\hline . & $\begin{array}{l}14 \\
15\end{array}$ & 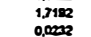 & $\begin{array}{l}12500 \\
0.5200\end{array}$ & $\begin{array}{l}0.4878 \\
0.00080\end{array}$ & $\begin{array}{l}7.17500 \\
0.0775\end{array}$ & $\begin{array}{l}3,2002 \\
2,4828\end{array}$ & 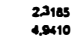 & $\begin{array}{l}0.0058 \\
0.0000\end{array}$ & $\begin{array}{l}0.0000 \\
0.0000\end{array}$ & $\begin{array}{l}0.6700 \\
0.011\end{array}$ & 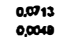 & 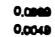 \\
\hline & $\begin{array}{l}18 \\
18\end{array}$ & 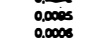 & . & $\begin{array}{l}0.000 \\
0.0000 \\
0.000\end{array}$ & $\begin{array}{l}0.0712 \\
0.014\end{array}$ & 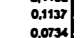 & $\begin{array}{l}0.0000 \\
0.0000 \\
0.000\end{array}$ & $\begin{array}{l}0.0000 \\
0.000 \\
0.000\end{array}$ & $\begin{array}{l}0.0000 \\
0.0000 \\
0.000\end{array}$ & 0.0000 & 0.0000 & $\begin{array}{l}0.0253 \\
0.000\end{array}$ \\
\hline & is & 0.0001 & 0.0007 & $\begin{array}{l}0.0000 \\
0.0000 \\
0.00\end{array}$ & 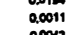 & 我, 0000 & 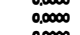 & . 0.0000 & D.0000 & 0.00000 & 0.0000 & 0.0000 \\
\hline 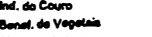 & 20 & 0.0000 & $\begin{array}{l}0.0000 \\
0.0000\end{array}$ & $\begin{array}{l}0.0000 \\
0.000\end{array}$ & 0.0011 & 年 & 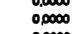 & 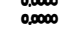 & 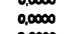 & 0.0000 & 年 & 0.0000 \\
\hline 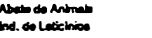 & $\begin{array}{l}21 \\
22\end{array}$ & $\begin{array}{l}0.0000 \\
0.0000\end{array}$ & $\begin{array}{l}0.0000 \\
0.0000\end{array}$ & $\begin{array}{l}0.0000 \\
0,0000\end{array}$ & $\begin{array}{l}0.0203 \\
0.0005\end{array}$ & 年 & $\begin{array}{l}0.0000 \\
0.0000 \\
0.000\end{array}$ & $\begin{array}{l}0.00000 \\
0.00000\end{array}$ & $\begin{array}{l}0.0000 \\
0.0000\end{array}$ & $\begin{array}{l}0.0000 \\
0.00000\end{array}$ & $\begin{array}{l}0.0000 \\
0.0000\end{array}$ & $\begin{array}{l}0.0000 \\
0.0000\end{array}$ \\
\hline 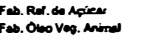 & $\begin{array}{l}20 \\
24\end{array}$ & $\begin{array}{l}\infty 000 \\
000\end{array}$ & $\begin{array}{l}0.01020 \\
0.0000\end{array}$ & $\begin{array}{l}0.0000 \\
0.0000\end{array}$ & $\begin{array}{l}0.0000 \\
0.00000\end{array}$ & | & $\begin{array}{l}0.00000 \\
0.00000\end{array}$ & $\begin{array}{l}0.00000 \\
0.00000\end{array}$ & $\begin{array}{l}0.0000 \\
0.0000\end{array}$ & $\begin{array}{l}0.0000 \\
0.0000\end{array}$ & $\begin{array}{l}0.0000 \\
0.0000\end{array}$ & $\begin{array}{l}0.000 \\
0.0000 \\
0.00\end{array}$ \\
\hline & ז8 & $\begin{array}{l}0.0000 \\
0.0000\end{array}$ & $\begin{array}{l}0.0004 \\
0.00050\end{array}$ & $\begin{array}{l}0.0004 \\
0.0000 \\
0.000\end{array}$ & $\begin{array}{l}0.0600 \\
0.0012 \\
0.012\end{array}$ & | 0.0775 & $\begin{array}{l}0.00000 \\
0.00000\end{array}$ & $\begin{array}{l}0.00000 \\
0.00000 \\
0\end{array}$ & $\begin{array}{l}0.0000 \\
0.0000\end{array}$ & $\begin{array}{l}0.00000 \\
0.0000\end{array}$ & $\begin{array}{l}0.0000 \\
0.0000\end{array}$ & $\begin{array}{l}0.0000 \\
0.0041\end{array}$ \\
\hline דומד & & $\begin{array}{l}0.0000 \\
0.0000 \\
0.000\end{array}$ & $\begin{array}{l}0.0000 \\
0.0000 \\
0.000\end{array}$ & $\begin{array}{l}0.000 \\
0.000 \\
0.000\end{array}$ & $\begin{array}{l}0.0000 \\
0.0000 \\
0.000\end{array}$ & .00000 & $\begin{array}{l}0.000 \\
0.000 \\
0.000\end{array}$ & $\begin{array}{l}0.0000 \\
0.000 \\
0.000\end{array}$ & $\begin{array}{l}0.0000 \\
0.0000 \\
0.000\end{array}$ & 0.0000 & $\begin{array}{l}0.0000 \\
0,0000\end{array}$ & 0.0000 \\
\hline 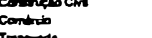 & 20 & .0.000 & 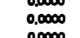 & 我.0000 & acoso & . & 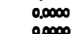 & .0.0000 & 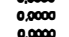 & $\begin{array}{l}0.0000 \\
0.006\end{array}$ & . 0.0000 & . 0.0000 \\
\hline & $\begin{array}{l}30 \\
311\end{array}$ & $\begin{array}{l}0.0000 \\
0.0000 \\
0.00\end{array}$ & $\begin{array}{l}0.0000 \\
0.0052\end{array}$ & $\begin{array}{l}0.0 .0010 \\
0.0010\end{array}$ & 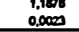 & 0.0101 & 0.0000 & 0.0000 & 0.0000 & 0.0000 & 0.0000 & 0.0000 \\
\hline rer & $\begin{array}{l}22 \\
33\end{array}$ & 0.0000 & 0.0001 & 0.0000 & 0,0000 & $\begin{array}{l}0.00021 \\
0.0017\end{array}$ & $\begin{array}{l}0.0 .607 \\
0.0000\end{array}$ & 0.0000 & 0.0000 & 0.0050 & 0.0000 & 0,0000 \\
\hline on & 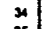 & 0.0000 & 0.0000 & 0.0000 & 00000 & 0.0000 & 0 & 0.0000 & 0.0000 & 0.0000 & cm & 0.0000 \\
\hline 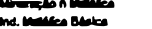 & $x_{30}$ & 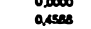 & 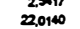 & $\begin{array}{l}0.0000 \\
0.0000\end{array}$ & 0 & 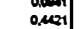 & $\begin{array}{l}0.00000 \\
0.0000\end{array}$ & 年 & $\begin{array}{l}0.0000 \\
0.0000\end{array}$ & $\begin{array}{l}0.048 \\
0.031 \\
0\end{array}$ & $\begin{array}{l}0.1000 \\
3.205\end{array}$ & .201261 \\
\hline & $\begin{array}{l}33 \\
3\end{array} \mid$ & $\begin{array}{l}0.12102 \\
0.0500\end{array}$ & $\begin{array}{l}2.20170 \\
2,7546\end{array}$ & $\begin{array}{l}0.1768 \\
0.20202\end{array}$ & 年 & $\begin{array}{l}3.4218606 \\
2,4006\end{array}$ & $\begin{array}{l}0.0000 \\
0.0000 \\
0.000\end{array}$ & $\begin{array}{l}0.0000 \\
0.0000\end{array}$ & $\begin{array}{l}0.0000 \\
0.00000\end{array}$ & $\begin{array}{l}0.014 \\
0.0000\end{array}$ & 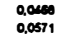 & $\begin{array}{l}0.1079 \\
0.0132\end{array}$ \\
\hline$\infty$ & 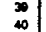 & 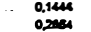 & 0 & 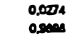 & 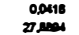 & 201000 & 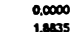 & $\begin{array}{l}0.0000 \\
0.0000\end{array}$ & $\begin{array}{l}0.0000 \\
00000\end{array}$ & $\begin{array}{l}0.0000 \\
0.000\end{array}$ & $\begin{array}{l}0.0000 \\
0.0000\end{array}$ & $\begin{array}{l}0.000 \\
0.000 \\
0.000\end{array}$ \\
\hline & 41 & 0.0000 & 0.0105 & 0.0130 & 0.0007 & 0.006 & 0.0000 & 0.0000 & 0.0000 & 0.00000 & 0.0000 & 0.0000 \\
\hline 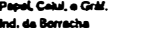 & $\begin{array}{l}42 \\
43\end{array}$ & $\begin{array}{l}0.0013 \\
0.0098\end{array}$ & $\begin{array}{l}0.0500 \\
0.5115\end{array}$ & $\begin{array}{l}\text { sosess } \\
0.0012\end{array}$ & 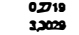 & $\mid$ & $\begin{array}{l}0.0000 \\
0.0000 \\
0.00\end{array}$ & $\begin{array}{l}0.0000 \\
0.0000 \\
0.00\end{array}$ & $\begin{array}{l}0.0000 \\
0.0000\end{array}$ & $\begin{array}{l}0.0200 \\
0.0200\end{array}$ & $\begin{array}{l}0.0000 \\
0.0000\end{array}$ & $\begin{array}{l}0,0000 \\
0.0000 \\
0.000\end{array}$ \\
\hline abtacos & 4 & 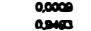 & $\begin{array}{l}0.0006 \\
0.0006 \\
0.000\end{array}$ & 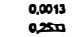 & 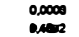 & 20.050 & $\begin{array}{l}0.0000 \\
0.1077\end{array}$ & $\begin{array}{l}0.00000 \\
0.0000\end{array}$ & $\begin{array}{l}0.0000 \\
0.0000 \\
0.00\end{array}$ & $\begin{array}{l}0.2022 \\
0.0310\end{array}$ & 0 & 0.0004 \\
\hline & 4 & 等 & 0.07402 & $\begin{array}{l}0.1115 \\
0.0000 \\
0.000\end{array}$ & $\begin{array}{l}0.0005 \\
0.0105\end{array}$ & . 3.5019 & 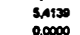 & $\begin{array}{l}0.0000 \\
0.0000 \\
0.000\end{array}$ & 然.0000 & 0.0121 & . o.0osit & o. 0.0054 \\
\hline & 4 & 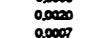 & 然 0.0004 & $\begin{array}{l}0,0000 \\
0.0000 \\
0.000\end{array}$ & $\begin{array}{l}0.003 \\
0.0018 \\
0.018\end{array}$ & . 22006 & $\begin{array}{l}0.0000 \\
0.000 \\
0.000\end{array}$ & $\begin{array}{l}0.0000 \\
0.000 \\
0.000\end{array}$ & $\begin{array}{l}0.0000 \\
0.0000 \\
0.000\end{array}$ & $\begin{array}{l}0.0000 \\
0.0000\end{array}$ & 然.00000 & 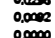 \\
\hline & so & o.0011 & 0.0000 & 0 & 0 & 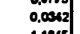 & 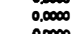 & 象, 000000 & 0.0000 & 0 & 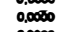 & 0.0000 \\
\hline & 82 & 0.0000 & $\begin{array}{l}0.0000 \\
0.0000\end{array}$ & $\begin{array}{l}0.00000 \\
0.0000\end{array}$ & $\begin{array}{l}0.0000 \\
0.000\end{array}$ & 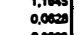 & 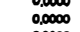 & 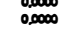 & 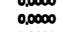 & $\begin{array}{l}0.0000 \\
0\end{array}$ & - 00000 & 0.0000 \\
\hline C. & $\stackrel{s 0}{s 0}$ & $\begin{array}{l}0.0000 \\
0.00000\end{array}$ & $\begin{array}{l}0.0000 \\
0.00000\end{array}$ & $\begin{array}{l}0.0000 \\
0.00000\end{array}$ & 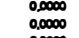 & 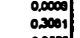 & $\begin{array}{l}0.0000 \\
0.00000\end{array}$ & $\begin{array}{l}0.0000 \\
0.0000 \\
0.000\end{array}$ & $\begin{array}{l}0.0000 \\
0.00000\end{array}$ & $\begin{array}{l}0.0000 \\
0.00000\end{array}$ & $\begin{array}{l}0.0000 \\
0.00000\end{array}$ & $\begin{array}{l}0.0000 \\
0.0000\end{array}$ \\
\hline & $s$ & $\begin{array}{l}0.0000 \\
0.00000\end{array}$ & $\begin{array}{l}0.0000 \\
0.0002\end{array}$ & $\begin{array}{l}0.0000 \\
0.00000\end{array}$ & 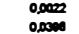 & 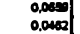 & $\begin{array}{l}0.0000 \\
0.00006\end{array}$ & $\begin{array}{l}0.00000 \\
0.00000\end{array}$ & $\begin{array}{l}0.0000 \\
0.00000\end{array}$ & $\begin{array}{l}0.0000 \\
0.00000\end{array}$ & $\begin{array}{l}0.0000 \\
0.00000\end{array}$ & $\begin{array}{l}0,0000 \\
0.0000\end{array}$ \\
\hline 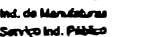 & 57 & 年. 0.171 & $\begin{array}{l}0.1801 \\
00000\end{array}$ & $\begin{array}{l}0.0047 \\
0.0000 \\
0.000\end{array}$ & 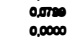 & $\left.\begin{array}{l}0.55077 \\
0.0000\end{array}\right]$ & $\begin{array}{l}0.0000 \\
0.000 \\
0.000\end{array}$ & $\begin{array}{l}0.0000 \\
0\end{array}$ & o. 000000 & $\begin{array}{l}0.0000 \\
00000\end{array}$ & 我 & $\begin{array}{l}0.1003 \\
0000\end{array}$ \\
\hline 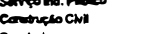 & & 0.0000 & 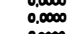 & $\begin{array}{l}0.0000 \\
0.0000\end{array}$ & 我. & 0.0000 & 0.0000 & 0.0000 & 0.0000 & 0.0000 & 0.0000 & 0.0000 \\
\hline & $\begin{array}{l}\infty \\
51\end{array}$ & $\begin{array}{l}0.0000 \\
0.0000\end{array}$ & $\begin{array}{l}0.0000 \\
0.0000\end{array}$ & 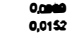 & $\begin{array}{l}0.0000 \\
1.9740\end{array}$ & | & $\begin{array}{l}0.0000 \\
0.0000\end{array}$ & $\begin{array}{l}0.000 \\
0.0000 \\
0.00\end{array}$ & $\begin{array}{l}0.0000 \\
0.00000\end{array}$ & $\begin{array}{l}0.0000 \\
0.00003 \\
0.00\end{array}$ & $\begin{array}{l}0.0000 \\
0.00000 \\
0\end{array}$ & $\begin{array}{l}0.0000 \\
0.0000\end{array}$ \\
\hline & & 0.0001 & 0.0557 & $\frac{0.0112}{1100}$ & 0.0254 & $\frac{0.11336}{1}$ & 0.0000 & 0.0000 & 0.0000 & 0.0000 & 必 & $m$ \\
\hline . & & $\begin{array}{l}0.0 .000 \\
0.2000\end{array}$ & $\begin{array}{l}3,1,1700 \\
40,7100\end{array}$ & $\begin{array}{l}1,2000 \\
12000 \\
100\end{array}$ & $\begin{array}{l}0,0000 \\
0.0000\end{array}$ & 象, 300000 & $\begin{array}{l}0.0744 \\
0.0000\end{array}$ & $\begin{array}{l}0.0000 \\
0.0000 \\
0.000\end{array}$ & $\begin{array}{l}0.0000 \\
0.0000\end{array}$ & $\begin{array}{l}0.0000 \\
0.0000\end{array}$ & 我 & $\begin{array}{l}0.0000 \\
0.0000\end{array}$ \\
\hline$a$ & as & 20000 & $\begin{array}{l}5,2000 \\
5\end{array}$ & 20000 & 2,0000 & 20000 & 0.0000 & 0.0000 & 0.0000 & 0.0000 & m & 0.0000 \\
\hline Stios & $\theta$ & 10000 & $=0200000$ & $\begin{array}{l}20000 \\
20000\end{array}$ & 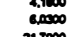 & 象, 800000 & $\begin{array}{l}0.0000 \\
0.0000\end{array}$ & $\begin{array}{l}0.0000 \\
0.00000\end{array}$ & $\begin{array}{l}0.0000 \\
0.00000\end{array}$ & $\begin{array}{l}0.014 \\
0.00110\end{array}$ & 0.1305 & $\begin{array}{l}0.0000 \\
0.061\end{array}$ \\
\hline & $\infty$ & $\begin{array}{l}230100 \\
32000\end{array}$ & $\begin{array}{l}10.40000 \\
8,7500\end{array}$ & $\begin{array}{l}17,1000 \\
11.00000\end{array}$ & $\begin{array}{l}2,7000 \\
7,7000\end{array}$ & 年 2000000 & $\begin{array}{l}0.0000 \\
0.00000\end{array}$ & $\begin{array}{l}0.0000 \\
0.0000 \\
0.000\end{array}$ & $\begin{array}{l}0.0000 \\
0.0000\end{array}$ & $\begin{array}{l}0.0005 \\
0.00000\end{array}$ & $\begin{array}{l}0.0015 \\
0.0008\end{array}$ & $\begin{array}{l}0.00000 \\
0.0001\end{array}$ \\
\hline rmangen & $\begin{array}{l}70 \\
71\end{array}$ & $\begin{array}{l}0.3500 \\
0.2000\end{array}$ & $\begin{array}{l}0.07000 \\
1,0000\end{array}$ & $\begin{array}{l}0.1 .1000 \\
3,0000\end{array}$ & 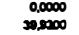 & 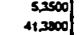 & $\begin{array}{l}0.0000 \\
0.0000\end{array}$ & $\begin{array}{l}0.000 \\
0.0000 \\
0.000\end{array}$ & $\begin{array}{l}0.0000 \\
0.0000\end{array}$ & $\begin{array}{l}0.00000 \\
0.00000\end{array}$ & 0.0000 & $\begin{array}{l}0.0000 \\
0.0000\end{array}$ \\
\hline (1) & & 0.2000 & 186.1300 & 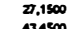 & 1000 & $\begin{array}{l}1,7,2200 \\
1\end{array}$ & $\begin{array}{l}0.0000 \\
0.000 \\
0.00\end{array}$ & 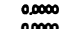 & 0.0000 & 0.0000 & $m$ & 0.0000 \\
\hline Sorroctose & 74 & $\begin{array}{l}20200 \\
0.2200\end{array}$ & $\begin{array}{l}17.600000 \\
3,0500\end{array}$ & $\begin{array}{l}252000 \\
3.2200\end{array}$ & 象 & 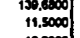 & $\begin{array}{l}0.0000 \\
0.0000\end{array}$ & $\begin{array}{l}0.0000 \\
0.0000\end{array}$ & $\begin{array}{l}0.0000 \\
0.00000\end{array}$ & $\begin{array}{l}-0.0000 \\
0.0000\end{array}$ & $\infty$ & $\begin{array}{l}0.0000 \\
0.0000\end{array}$ \\
\hline a & $\begin{array}{l}75 \\
76\end{array}$ & $\begin{array}{l}2,1000 \\
17 \pi 000\end{array}$ & $\begin{array}{c}1.007000 \\
40.8000\end{array}$ & 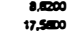 & $\begin{array}{l}0.00000 \\
x \rightarrow, 00500\end{array}$ & $\mid$ & $\begin{array}{l}0.0000 \\
0.0000\end{array}$ & $\begin{array}{l}0.0000 \\
0.0000 \\
0.000\end{array}$ & $\begin{array}{l}0.0000 \\
0.00000\end{array}$ & $\begin{array}{l}0.00013 \\
0.00220\end{array}$ & $\begin{array}{l}\infty \\
002 \\
02\end{array}$ & $\begin{array}{l}0.00000 \\
0.0003\end{array}$ \\
\hline ar & in & o & $\begin{array}{l}30,000 \\
501500\end{array}$ & 507500 & 20000 & 勇, & 0 & 我00000 & mom & 0.0000 & m. & 0.0001 \\
\hline & $\begin{array}{l}76 \\
70\end{array}$ & $\begin{array}{l}0.100 \\
0.1000\end{array}$ & $\begin{array}{l}2.151300 \\
21,5000\end{array}$ & $\begin{array}{l}0.7500 \\
\text { s.00000 }\end{array}$ & 岱 & 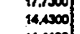 & $\begin{array}{l}0.0000 \\
0.00000\end{array}$ & $\begin{array}{l}0.0000 \\
0.0000 \\
0.00\end{array}$ & $\begin{array}{l}0.0000 \\
0.00000 \\
0.00\end{array}$ & $\begin{array}{l}0.00000 \\
0.00000\end{array}$ & $\begin{array}{l}0.0000 \\
0.00000\end{array}$ & $\begin{array}{l}0.00001 \\
0,00000\end{array}$ \\
\hline & & $\begin{array}{l}0.700 \\
0.700\end{array}$ & $\begin{array}{l}1.0000 \\
1.5000\end{array}$ & $\begin{array}{l}12000 \\
0.0000 \\
0.00\end{array}$ & $\begin{array}{l}8,100 \\
0.12000\end{array}$ & 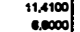 & $\begin{array}{l}0.000 \\
0.0000 \\
0.000\end{array}$ & 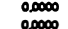 & 0 & $\begin{array}{l}0.00000 \\
0,0000\end{array}$ & 我 & 0.0000 \\
\hline$\infty$ & 20 & 0.0100 & 3,00000 & 1,000 & 10000 & $\infty 2000$ & 0.0000 & 0.0000 & 0.00000 & & 0.000 & 0.00000 \\
\hline & 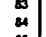 & $\begin{array}{l}0.01000 \\
0.01000\end{array}$ & $\begin{array}{l}0.0000 \\
0.0700\end{array}$ & $\begin{array}{l}0.0000 \\
0.0000 \\
0.000\end{array}$ & 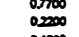 & 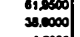 & $\begin{array}{l}0.0000 \\
0.00000\end{array}$ & $\begin{array}{l}0.0000 \\
0.00000\end{array}$ & $\begin{array}{l}0.0000 \\
0.00000\end{array}$ & $\begin{array}{l}0.00000 \\
0.00000\end{array}$ & $\begin{array}{l}0.0000 \\
0.00000\end{array}$ & $\begin{array}{l}0.00000 \\
0.0000\end{array}$ \\
\hline Sere & as & $\begin{array}{l}0.0000 \\
0.0000\end{array}$ & $\begin{array}{l}0.10000 \\
0.20000\end{array}$ & $\begin{array}{l}0.000 \\
0.0000\end{array}$ & 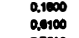 & {$\left[\begin{array}{c}6,00000 \\
6\end{array}\right.$} & $\begin{array}{l}0.0000 \\
0.0000\end{array}$ & $\begin{array}{l}0.0000 \\
0.0000\end{array}$ & $\begin{array}{l}0.0000 \\
0.00000 \\
0\end{array}$ & $\begin{array}{l}0.00000 \\
0.00000\end{array}$ & $\begin{array}{l}0.00000 \\
0.00000\end{array}$ & $\begin{array}{l}0.0000 \\
0.0000\end{array}$ \\
\hline$m$ & $\infty$ & $\begin{array}{l}0.1100 \\
0.08500\end{array}$ & $\begin{array}{l}1,1300 \\
1,5000 \\
\text { is }\end{array}$ & $\begin{array}{l}\text { as } \\
25000 \\
24000\end{array}$ & $\begin{array}{l}25000 \\
1,0000\end{array}$ & 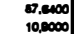 & $\begin{array}{l}0.0000 \\
0.0000 \\
0.000\end{array}$ & $\begin{array}{l}0.0000 \\
0.00000\end{array}$ & $\begin{array}{l}.00000 \\
0.0000\end{array}$ & $\begin{array}{l}0.0000 \\
0,0000\end{array}$ & $\begin{array}{l}0.0000 \\
0.0000\end{array}$ & $\begin{array}{l}0,0000 \\
0.00001\end{array}$ \\
\hline 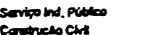 & $\infty$ & 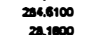 & $\underset{1.10000}{+40000}$ & $\begin{array}{l}A, 1000 \\
0.20000\end{array}$ & 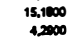 & $\begin{array}{l}1122000 \\
3177000\end{array}$ & $\begin{array}{l}0.000 \\
0.000 \\
0.000\end{array}$ & $\begin{array}{l}0.0000 \\
0.0000\end{array}$ & $\begin{array}{l}0.0000 \\
0.0000\end{array}$ & $\begin{array}{l}0.0000 \\
0.0000\end{array}$ & $\begin{array}{l}0.0000 \\
0.0000\end{array}$ & $\begin{array}{l}0.0000 \\
0.0000\end{array}$ \\
\hline & & 11,1400 & 20000000 & 10,0000 & 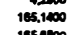 & 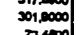 & 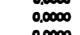 & $\begin{array}{l}0.0000 \\
0.000 \\
.0 m 0\end{array}$ & 0.00000 & 0.00000 & 0.0000 & 0.0000 \\
\hline & & 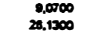 & $\begin{array}{l}202000 \\
80,7000\end{array}$ & $\begin{array}{l}14,72000 \\
3734000\end{array}$ & 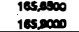 & $\begin{array}{c}7070,000 \\
20000\end{array}$ & $\begin{array}{l}0.0000 \\
0.0000\end{array}$ & & $\begin{array}{l}0.0000 \\
0.0000\end{array}$ & 我 000 & & $\begin{array}{l}0.0000 \\
00000\end{array}$ \\
\hline & & 0.0000 & & & & & & & & & & \\
\hline & & 0.0000 & 0.000 & 0.0000 & mon & 0,0000 & 0.0000 & 0.0000 & 0.0000 & & & \\
\hline & & .0000 & & 0.00000 & 00 & 0,000 & 0.0000 & & $\infty$ & & & 0.00 \\
\hline & & 0.0002 & 0.0 & $\begin{array}{l}0.0000 \\
0.000\end{array}$ & 年 & 我 & 年 & & 0.00000 & & & 0.00 \\
\hline & $\infty$ & 0.0008 & 0.01 . & 0.0012 & 0.0 & 0 & 2020500 & 4,500 & 0.0000 & & os & and \\
\hline & & $\begin{array}{l}0.0001 \\
0.0000\end{array}$ & $\begin{array}{l}0.00 \\
0.00\end{array}$ & $\begin{array}{l}0.0001 \\
0.00000\end{array}$ & 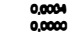 & 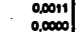 & $\begin{array}{l}0.0000 \\
0.000 \\
0 \times 00\end{array}$ & $\begin{array}{l}0.0000 \\
0.0000 \\
0.000\end{array}$ & $\begin{array}{l}0.0000 \\
0.0000\end{array}$ & 1.0 & $\begin{array}{l}02000 \\
0,00000\end{array}$ & 0.0700 \\
\hline & & 0,0000 & 0.00000 & 0.0000 & & 年 & 0.0000 & & & & & $\begin{array}{l}0.0000 \\
0.0000\end{array}$ \\
\hline & 10 & 0,0000 & 0.0000 & 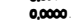 & & $n$ & 0.1100 & 0.0000 & 0.0000 & & & ס \\
\hline w. o & $\mid$ & 0.0000 & $\begin{array}{c}0.00 \\
0.00\end{array}$ & 0.00 & & & $\begin{array}{l}0.0000 \\
0.00000\end{array}$ & $\begin{array}{l}0.0000 \\
0.0000 \\
0.00\end{array}$ & $\begin{array}{l}0.0000 \\
0.0000\end{array}$ & & $\infty$ & 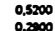 \\
\hline & & 0,0000 & 0,0001 & 0.0000 & 0.0 & 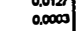 & 0.0000 & 0.0000 & 0.0000 & & 0,4100 & 0.2000 \\
\hline & 100 & $\begin{array}{l}0.0000 \\
0.0015\end{array}$ & $\begin{array}{l}0.00 \\
0.000\end{array}$ & $\begin{array}{l}0.0000 \\
0.0050\end{array}$ & $\begin{array}{l}0.00000 \\
0.0007\end{array}$ & $\begin{array}{l}0.00000 \\
0.19801\end{array}$ & $\begin{array}{l}0,15000 \\
47,1100\end{array}$ &  & $\begin{array}{l}0.0000 \\
0.00000\end{array}$ & & 0.00000 & 180 \\
\hline & 100 & 0.0000 & 0.000 & 0.00000 & .00000 & 0.0001 & 0 & m & 0.00000 & & 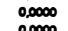 & 0.50000 \\
\hline & $\begin{array}{l}110 \\
111\end{array}$ & $\begin{array}{l}0.0001 \\
0.0000\end{array}$ & 0.0 & $\begin{array}{l}0.0000 \\
0.0000\end{array}$ & $\begin{array}{l}0.0001 \\
0.0012\end{array}$ & 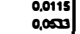 & $\begin{array}{l}5.500 \\
0.0000\end{array}$ & $\begin{array}{l}0.000 \\
0.0000 \\
0.000\end{array}$ & $\begin{array}{l}0.0000 \\
0.0000\end{array}$ & & $\infty$ & $\begin{array}{l}0.11 \\
0.0\end{array}$ \\
\hline & 112 & 0.0009 & 0.0000 & 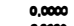 & & scant & 0.0000 & 0.00000 & 政 & & $m$ & $0 . \infty$ \\
\hline & 113 & $\begin{array}{l}0.00000 \\
: 0000\end{array}$ & $0.0,0$ & 0.000 & 0.0 & 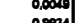 & 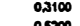 & 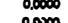 & $\begin{array}{c}0.0000 \\
0.000\end{array}$ & & & 0.00 \\
\hline & 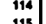 & $\begin{array}{l}0.0000 \\
0.0000\end{array}$ & $\begin{array}{l}0.0000 \\
0.0000\end{array}$ & 0.0 & & 年 & $\begin{array}{l}0.5000 \\
0.0000\end{array}$ & 㒸 & $\begin{array}{l}0.0000 \\
0.00000\end{array}$ & & 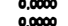 & 0 \\
\hline & 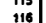 & 0.0000 & $0 . \alpha$ & 0.0000 & $\begin{array}{l}0.0 \\
0.0 \\
0.0\end{array}$ & 0 & 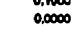 & 0.0000 & 0.0000 & & 0.0000 & 00000 \\
\hline & & & 0,0000 & & & & 0.1000 & 0.0000 & 0.0000 & & 0.0000 & 0.0000 \\
\hline & 118 & 0.0000 & 0.0000 & & & 0.00000 & 50,00000 & 0.0000 & 0.0000 & & $\infty 00$ & 0.00 \\
\hline 1000 & 119 & 0.00000 & 0.00 & 1 & 0.0 & 0.0000 & 0.0000 & 0,0000 & 0.0000 & 22 & 0.0500 & 0.18 \\
\hline 些 & 120 & 0.00000 & 0.00000 & 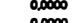 & 0 & : & 1,7500 & $\begin{array}{l}0.05000 \\
0.000\end{array}$ & o. 0.0000 & & & \\
\hline & $n$ & 禹 & $0 \alpha$ & & & & 14.8. & & $\begin{array}{l}0.00000 \\
0.00000\end{array}$ & & & $\begin{array}{l}0.1000 \\
0.15400\end{array}$ \\
\hline & & .000 & 0 & 0.0000 & 100 & 0.0253 & 709500 & ${ }_{11.500}$ & 0 & $s_{22}$ & 0.1500 & 0 \\
\hline & 124 & 0.0003 &  & 0.0062 & 0.01 & 0.0031 & $10 \times 0 \times$ & 1,4100 & 0.0000 & 4.00 & 0 & 4.0000 \\
\hline 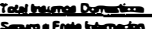 & 125 & & & & & & & & $\overline{0 \infty}$ & & & 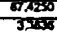 \\
\hline 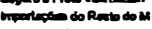 & 120 & insoses & 15258060 & w.1.1272 & 2007000 & $30,202 \pi$ & 32,7409 & 0.0115 & 0.0000 & 3.1122 & $0.00 \mathrm{ses}$ & 0.0354 \\
\hline . & $\begin{array}{l}702 \\
100\end{array}$ & 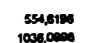 & 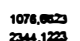 & $\begin{array}{l}2000 \pi 14 \\
\operatorname{cosec} 2116\end{array}$ & 1100.7500 & $\begin{array}{l}202850200 \\
0751.670\end{array}$ & $\begin{array}{c}784205050 \\
1310,1356\end{array}$ & 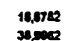 & $\begin{array}{l}0.0000 \\
0.0000\end{array}$ & 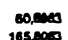 & $\begin{array}{l}17205 \\
10045 \\
0.457\end{array}$ & $\begin{array}{c}702258 \\
130,1050\end{array}$ \\
\hline
\end{tabular}




\begin{tabular}{|c|c|c|c|c|c|c|c|c|c|c|c|c|}
\hline soses & & ${ }_{100}^{E \omega 0}$ & - & 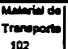 & | & 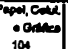 & itimens & | & 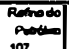 & 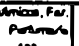 & 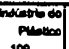 & Thastores \\
\hline Lowher & $\frac{1}{2}$ & & & & 0.0071 & & & $\frac{10.0000}{0.0000}$ & & $100 \quad 1$ & $\frac{100}{0.0000}$ & 110 \\
\hline oses & & $\begin{array}{l}0.0000 \\
0.0000\end{array}$ & 0.0000 & $\begin{array}{l}0.0000 \\
0.000\end{array}$ & $\begin{array}{l}0.00000 \\
0.00000\end{array}$ & $\begin{array}{l}0.0000 \\
0.0000\end{array}$ & $\begin{array}{l}0.0001 \\
0.0000\end{array}$ & $\begin{array}{l}0.0000 \\
0.0000\end{array}$ & $\begin{array}{l}0.0020 \\
0.00000 \\
0.00\end{array}$ & $\begin{array}{l}0.00077 \\
0.0000\end{array}$ & $\begin{array}{l}0.0000 \\
0.0000\end{array}$ & $\begin{array}{l}0.0000 \\
0.000\end{array}$ \\
\hline 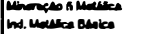 & 3 & $\begin{array}{l}0.009 \\
0.0774\end{array}$ & $\begin{array}{l}0.00000 \\
0.0000\end{array}$ & 0.0030 & 0.0011 & 0.0039 & 0.0000 & 0.000 & 0.0000 & 0.0016 & 0.0000 & 0 \\
\hline 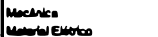 & ; & $\begin{array}{l}0.005 \\
0.0000 \\
0.000\end{array}$ & 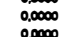 & $\begin{array}{l}0.020 \\
0.02005 \\
0.005\end{array}$ & $\begin{array}{l}0.01000 \\
0.0000\end{array}$ & 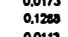 & 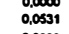 & $\begin{array}{l}0.0010 \\
0.0018\end{array}$ & $\begin{array}{l}0.0002 \\
0.0005\end{array}$ & $\begin{array}{l}0.10222 \\
0.0270\end{array}$ & $\begin{array}{l}0.0010 \\
0.0000\end{array}$ & $\begin{array}{l}0.0 .016 \\
0.2000\end{array}$ \\
\hline & & 0.0000 & 0.0000 & & $\begin{array}{l}0.0000 \\
0.0000\end{array}$ & $\begin{array}{l}0.00000 \\
0.0000\end{array}$ & $\begin{array}{l}0.0000 \\
0.0000 \\
0.000\end{array}$ & $\begin{array}{l}0.0000 \\
0.0000\end{array}$ & $\begin{array}{l}0.0000 \\
0.0000\end{array}$ & $\begin{array}{l}0.0000 \\
0.0000\end{array}$ & 我地 & $\begin{array}{l}0.0011 \\
0.000 \\
0.000\end{array}$ \\
\hline maperst & io & $\begin{array}{l}0.0000 \\
0.000 \\
0.00\end{array}$ & $\begin{array}{l}0.0000 \\
0.000 \\
0.000\end{array}$ & 4.0005 & 0.00000 & 0.0000 & 0.0000 & 0.0000 & o.coses & 0.0000 & 0.0000 & 0.0000 \\
\hline condeconter & $" 1$ & 年 &  & 年 & 0.0000 & 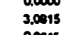 & $\begin{array}{l}0.0000 \\
0.0000\end{array}$ & $\begin{array}{l}0.0000 \\
0.0000\end{array}$ & $\begin{array}{l}0.0000 \\
0.0000\end{array}$ & $\begin{array}{l}0.0000 \\
0.0021\end{array}$ & $\begin{array}{l}0.0000 \\
0.0000\end{array}$ & $\begin{array}{l}0.0000 \\
0.00000\end{array}$ \\
\hline aneses & 13 & 0.0074 & 0.00000 & $\begin{array}{l}0.0000 \\
0.0000\end{array}$ & $\begin{array}{l}0.00007 \\
0.0187\end{array}$ & $\begin{array}{l}0.01378 \\
0.0786\end{array}$ & ס & $\begin{array}{l}0.0000 \\
0.72000\end{array}$ & $\begin{array}{l}0.0 .062 \\
0.1705\end{array}$ & $\begin{array}{l}0.0000 \\
.702010\end{array}$ & $\begin{array}{l}0.015 \\
0.1145\end{array}$ & $\begin{array}{l}0.030 \\
1,1722\end{array}$ \\
\hline oferopost & 15 & $\begin{array}{l}0.0725 \\
0.0725 \\
0.07\end{array}$ & $\begin{array}{l}0.0000 \\
0.0000\end{array}$ & $\begin{array}{l}0.0214 \\
0.0184\end{array}$ & $\begin{array}{l}0.028 \\
0.0081\end{array}$ & $\begin{array}{l}0.1234 \\
0.0853\end{array}$ & $\begin{array}{l}0.0000 \\
0.01000\end{array}$ & $\begin{array}{l}0.02214 \\
0.0615\end{array}$ & $\begin{array}{l}5 \text { sers } \\
0.0000\end{array}$ & 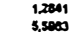 & $\begin{array}{l}0.0071 \\
20000\end{array}$ & $\begin{array}{l}0.2000 \\
i, 000\end{array}$ \\
\hline 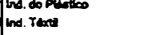 & $\begin{array}{l}16 \\
17\end{array}$ & $\begin{array}{l}0.0000 \\
0.0901 \\
0.000\end{array}$ & $\begin{array}{l}0.0000 \\
0.00000\end{array}$ & $\begin{array}{l}0.0000 \\
0.0108\end{array}$ & $\begin{array}{l}0.00000 \\
0.00000\end{array}$ & $\begin{array}{l}0.000 \\
0.416 \\
0.416\end{array}$ & $\begin{array}{l}0.0000 \\
100040\end{array}$ & $\begin{array}{l}0.0003 \\
0.0000\end{array}$ & 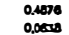 & $\begin{array}{l}0.10000 \\
0.0000\end{array}$ & $\begin{array}{l}0.000 \\
0.0002 \\
0.000\end{array}$ & $\begin{array}{l}0.2112 \\
3.612 \\
3.612\end{array}$ \\
\hline 10 & $\begin{array}{l}18 \\
10\end{array}$ & $\begin{array}{l}0.0000 \\
0.0000\end{array}$ & $\begin{array}{l}0.0000 \\
0.0000 \\
0.00\end{array}$ & $\begin{array}{l}0.0000 \\
0.0000\end{array}$ & $\begin{array}{l}0.0000 \\
0.00000 \\
0.00\end{array}$ & $\begin{array}{l}0.0000 \\
0.0000 \\
0.00\end{array}$ & $\begin{array}{l}0.00000 \\
0.0000\end{array}$ & $\begin{array}{l}0.0000 \\
0.0000\end{array}$ & $\begin{array}{l}0.0000 \\
0.000 \\
0.000\end{array}$ & $\begin{array}{l}0.0000 \\
00000\end{array}$ & 然 0.0000 & $\begin{array}{l}0.0000 \\
0.000 \\
0.00\end{array}$ \\
\hline 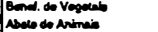 & $\begin{array}{l}20 \\
21\end{array}$ & $\begin{array}{l}0.0000 \\
0.0000\end{array}$ & $\begin{array}{l}0.0000 \\
0.0000 \\
0\end{array}$ & $\begin{array}{l}0.0000 \\
0.0000 \\
0.000\end{array}$ & $\begin{array}{l}0.0000 \\
0.0000\end{array}$ & $\begin{array}{l}0.0000 \\
0.000 \\
0.000\end{array}$ & 0.0000 & 0.0000 & 0.0000 & 0.00000 & . 0.0000 & 0.0000 \\
\hline 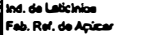 & $\begin{array}{l}2 \\
2\end{array}$ & $\begin{array}{l}0.0000 \\
0.000 \\
0.000\end{array}$ & $\begin{array}{l}0.0000 \\
0.0000\end{array}$ & $\begin{array}{l}0.000 \\
0.000 \\
0.000\end{array}$ & $\begin{array}{l}0.0000 \\
0.000\end{array}$ & 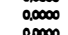 & . 0.0000 & 0.0000 & 告. 0.0000 & 0.00000 & . & $\begin{array}{l}0.0000 \\
0.0000\end{array}$ \\
\hline & & 0.0000 & 0.0000 & 0.0000 & 0.0000 & 0.0000 & $\begin{array}{l}0.00000 \\
0.0187\end{array}$ & 0.0000 & $\begin{array}{l}0.000 \\
0.000 \\
0.000\end{array}$ & $\begin{array}{l}0.9260 \\
0.5250 \\
0.5125\end{array}$ & $\begin{array}{l}0.0000 \\
0.0000\end{array}$ & $\begin{array}{l}0.0000 \\
0.0000 \\
0\end{array}$ \\
\hline 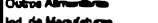 & 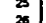 & 0.0000 & 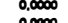 & 0.0000 & 0.0000 & 0.0000 & 0.0000 & 0.0000 & 0.0000 & 0.0241 & $\infty 00$ & 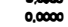 \\
\hline 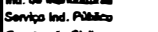 & $z$ & 0.0000 & 0.0000 & $\begin{array}{l}0.0010 \\
0.0000\end{array}$ & $\begin{array}{l}0.0000 \\
0.0000\end{array}$ & $\begin{array}{l}0.0013 \\
0.0000\end{array}$ & $\begin{array}{l}0.00000 \\
0.0000\end{array}$ & $\begin{array}{l}0.0000 \\
0.0000\end{array}$ & $\begin{array}{l}0.0000 \\
0.0000\end{array}$ & $\begin{array}{l}0,0000 \\
0.0000 \\
0.00\end{array}$ & $\begin{array}{l}0.0000 \\
0.000 \\
0.000\end{array}$ & 0.0001 \\
\hline & $\begin{array}{l}28 \\
20\end{array}$ & $\begin{array}{l}0.0000 \\
0.0000\end{array}$ & $\begin{array}{l}0.0000 \\
.00000 \\
0.000\end{array}$ & $\begin{array}{l}0.0000 \\
0.00000\end{array}$ & $\begin{array}{l}0.0000 \\
0.0000 \\
0.000\end{array}$ & $\begin{array}{l}0.0000 \\
0.00000 \\
0.00\end{array}$ & $\begin{array}{l}0.00000 \\
0,0000\end{array}$ & $\begin{array}{l}0.0000 \\
0.0000\end{array}$ & $\begin{array}{l}0.000 \\
0.000 \\
0.000\end{array}$ & $\begin{array}{l}0.0000 \\
00000\end{array}$ & 然 00000 & $\begin{array}{l}0.0000 \\
0000\end{array}$ \\
\hline 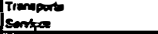 & . & $\begin{array}{l}0.00000 \\
0.0000\end{array}$ & $\begin{array}{l}0.0000 \\
0.0000\end{array}$ & $\begin{array}{l}0.0000 \\
0.00000\end{array}$ & $\begin{array}{l}0.0000 \\
0.0000\end{array}$ & $\begin{array}{l}0.000 \\
0.0000 \\
0.000\end{array}$ & $\begin{array}{l}0.0000 \\
0.0000\end{array}$ & $\begin{array}{l}0.0000 \\
00000\end{array}$ & $\begin{array}{l}0.0000 \\
0.000 \\
0.000\end{array}$ & $\begin{array}{l}0.0000 \\
00000\end{array}$ & $\begin{array}{l}0.000 \\
0.000 \\
0.000\end{array}$ & 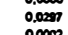 \\
\hline 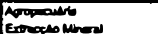 & 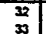 & $\begin{array}{l}0.0000 \\
0.0000\end{array}$ & 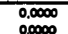 & 它.0000 & $\begin{array}{l}0.0070 \\
0.000\end{array}$ & 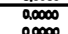 & 0.0 .3075 & 0.0000 & 0.0000 & 0.0172 & $\frac{0.0000}{0.0000}$ & $\frac{0.008}{100050}$ \\
\hline & 34 & 0,0000 & 0.0000 & 0.0000 & 0.0000 & 然, 00000 & 0.0000 & 0.0000 & 0,0000 & 年 & $\begin{array}{l}0.0000 \\
0.0000\end{array}$ & $\begin{array}{l}0.0000 \\
0.0000\end{array}$ \\
\hline 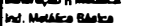 & 36 & $\begin{array}{l}0.005 \\
.0052\end{array}$ & $\begin{array}{l}0.0000 \\
.00000\end{array}$ & $\begin{array}{l}0.0003 \\
.271702\end{array}$ & $\begin{array}{l}0.0001 \\
0.37 \%\end{array}$ & 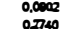 & $\begin{array}{l}0.0000 \\
0.000\end{array}$ & 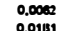 & $\begin{array}{l}0.0000 \\
0.451\end{array}$ & 0.0071 & 0.0000 & 0.0000 \\
\hline & 37 & 0.058 & 0.00000 & 0.0940 & 0.0151 & 0.1000 & 0.0744 & 0025 & 0.0058 & 0,0001 & 0.0000 & 年 \\
\hline t) & 30 & $\begin{array}{l}0.0000 \\
0.0000\end{array}$ & $\begin{array}{l}0.0000 \\
0.0000\end{array}$ & $\begin{array}{l}0.0003 \\
0.0000\end{array}$ & $\begin{array}{l}0.0000 \\
0.0000 \\
0.00\end{array}$ & $\begin{array}{l}0.0025 \\
0.0000 \\
0.000\end{array}$ & $\begin{array}{l}0.00000 \\
0.0000\end{array}$ & $\begin{array}{l}0.0000 \\
0.0000\end{array}$ & $\begin{array}{l}0.0000 \\
0.0000 \\
0.000\end{array}$ & $\begin{array}{l}0.0000 \\
0.0000\end{array}$ & $\begin{array}{l}0.0000 \\
0.000 \\
0.000\end{array}$ & $\begin{array}{l}0.0073 \\
0.000\end{array}$ \\
\hline troppos & $\stackrel{+\infty}{*}$ & o.0000 & o.0000 & 82701 & 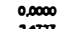 & 0.0000 & 0.0000 & 0.0000 & 0.5300 & 0.00000 & 0.0000 & 0.0000 \\
\hline cowlo ardt. & 42 & 0.0140 & 0.0000 & 0.0200 & 0.0000 & $\begin{array}{l}0.0000 \\
0.035 s \\
0.00\end{array}$ & $\begin{array}{l}0.00000 \\
0.0000\end{array}$ & 我位 & $\begin{array}{l}0.0000 \\
0.0000\end{array}$ & $\begin{array}{l}0.0000 \\
0.1976\end{array}$ & $\begin{array}{l}0.0000 \\
0.0000\end{array}$ & $\begin{array}{l}0.0003 \\
0.1172\end{array}$ \\
\hline Detes & $\begin{array}{l}43 \\
4\end{array}$ & $\begin{array}{l}0.02000 \\
0.0149\end{array}$ & $\begin{array}{l}0.0000 \\
.00000 \\
0.000\end{array}$ & $\begin{array}{l}0.9000 \\
0.0000\end{array}$ & $\begin{array}{l}0.0000 \\
0.0074\end{array}$ & $\begin{array}{l}0.000 \\
0.056 \\
0.560\end{array}$ & $\begin{array}{l}0.58000 \\
0.1004\end{array}$ & $\begin{array}{l}0.0000 \\
0.3162 \\
0.00\end{array}$ & $\begin{array}{l}0.3500 \\
0.0090\end{array}$ & $\begin{array}{l}0.0000 \\
3.1772\end{array}$ & $\begin{array}{l}0.0100 \\
0.0735\end{array}$ & $\begin{array}{l}0.1000 \\
0.0000\end{array}$ \\
\hline 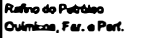 & $\begin{array}{l}45 \\
46\end{array}$ & 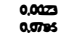 & $\begin{array}{l}0.00000 \\
.00000\end{array}$ & $\begin{array}{l}0.0010 \\
0.020202\end{array}$ & 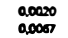 & $\begin{array}{l}0.0050 \\
0.071000\end{array}$ & $\begin{array}{l}0.0002 \\
0.0005\end{array}$ & $\begin{array}{l}0.0010 \\
0.0744\end{array}$ & $\begin{array}{l}0.0721 \\
0.0000 \\
0.000\end{array}$ & 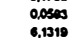 & 然, 0000 & 0.0122 \\
\hline $\ln$ & 47 & $\begin{array}{l}0.5104 \\
0.0000\end{array}$ & $\begin{array}{l}0.0000 \\
0.0000\end{array}$ & $\begin{array}{l}0.0000 \\
0.0124\end{array}$ & $\begin{array}{l}0.0000 \\
0.000 \\
0.000\end{array}$ & $\begin{array}{l}0.000 \\
0.003 \\
0.703\end{array}$ & $\begin{array}{l}0.00000 \\
2,4310\end{array}$ & o.10077 & 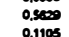 & 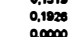 & 0.0000 & 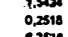 \\
\hline & $\begin{array}{l}40 \\
40\end{array}$ & $\begin{array}{l}0.0000 \\
0.0000\end{array}$ & $\begin{array}{l}0.0000 \\
0.0000\end{array}$ & $\begin{array}{l}0.0000 \\
0.0000\end{array}$ & $\begin{array}{l}0.0000 \\
0.0000\end{array}$ & $\begin{array}{l}0.000 \\
0.0000 \\
0.000\end{array}$ & $\begin{array}{l}0.0000 \\
0.0000\end{array}$ & $\begin{array}{l}0.0000 \\
0.0000 \\
0.0000\end{array}$ & $\begin{array}{l}0.1000 \\
0.0000 \\
0.000\end{array}$ & $\begin{array}{l}0.0000 \\
0,0000 \\
0,0000\end{array}$ & $\begin{array}{l}0.1000 \\
0.0000 \\
0.000\end{array}$ & 年 \\
\hline 0 & 31 & 0.0000 & . 0.0000 & 年, 00000 & 象, 00000 & 0.0000 & 0.0000 & $\begin{array}{l}0.0000 \\
0.0000\end{array}$ & $\begin{array}{l}0.0000 \\
0.0000\end{array}$ & $\begin{array}{l}0.0000 \\
0.0000\end{array}$ & $\begin{array}{l}0.0000 \\
0.0000\end{array}$ & $\begin{array}{l}0.000 \\
0.0000\end{array}$ \\
\hline 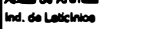 & 5 & 0.0000 & 0 & $\begin{array}{l}0.0000 \\
0.000\end{array}$ & 年 & $\begin{array}{l}0.0000 \\
0.0000\end{array}$ & $\begin{array}{l}0.0000 \\
0.0000\end{array}$ & $\begin{array}{l}0.0000 \\
0.0000\end{array}$ & $\begin{array}{l}0.0000 \\
0.0000\end{array}$ & $\begin{array}{l}0.0000 \\
0.0000 \\
0.00\end{array}$ & $\begin{array}{l}0.0000 \\
0.0000\end{array}$ & $\begin{array}{l}0.0000 \\
0.0000 \\
0.00\end{array}$ \\
\hline 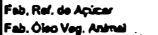 & $\begin{array}{l}54 \\
5 s\end{array}$ & 然 00000 & o. 0.000 & 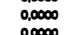 & .0.000 & $\begin{array}{l}0.000 \\
0.000 \\
0.000\end{array}$ & 0.00000 & . 0.00000 & 年 & 0.01000 & $\begin{array}{l}0.0000 \\
0.0000\end{array}$ & $\begin{array}{l}0.000 \\
0.000\end{array}$ \\
\hline & so & 0,0000 & 0.0000 & 0.0000 & 0.0000 & 年 0.0000 & 0.00000 & 年 & $\begin{array}{l}0.0000 \\
0.000\end{array}$ & $\begin{array}{l}0.00212 \\
0.0060\end{array}$ & $\begin{array}{l}0.0000 \\
0.0000\end{array}$ & $\begin{array}{l}0.0537 \\
0.0000\end{array}$ \\
\hline 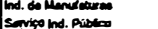 & 58 & $\begin{array}{l}0.0000 \\
0.0000\end{array}$ & 0.0000 & 0.0227 & 0.0000 & 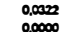 & 0.0000 & 0.0000 & 0.0020 & 0.0000 & 然 00000 & 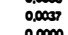 \\
\hline $\mathrm{F}=\mathrm{CNA}$ & so & 0.0000 & 0.0000 & 0.0000 & 0.0000 & 0,0000 & 0.0000 & $\begin{array}{l}0.0000 \\
0.0000\end{array}$ & 0.0000 & 0.0000 & 0.0000 & $\begin{array}{l}0.0000 \\
0.0000\end{array}$ \\
\hline & 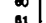 & $\begin{array}{l}0.0000 \\
0000\end{array}$ & 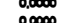 & 0.0000 & 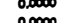 & 0.0000 & 0.0000 & $\infty$ & 0.0000 & 0.0000 & $\infty$ & 0.0000 \\
\hline & a & 0.0000 & 0.0000 & 我 & 0.0000 & 0.0000 & 0 & $\begin{array}{l}\infty 000 \\
\infty 000\end{array}$ & $\begin{array}{l}0.0000 \\
0.0000\end{array}$ & $\begin{array}{l}0.0000 \\
0.0000\end{array}$ & $\begin{array}{l}0.0000 \\
0.000\end{array}$ & 0.0177 \\
\hline 年 & $\infty$ & 0.0000 & 0.0000 & 0.0000 & 0.0020 & 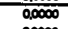 & 0.00097 & 0.000 & 0.0000 & $\frac{0.0017}{0.007}$ & 0.0000 & 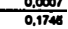 \\
\hline 0.04 & as & 0.0000 & & 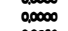 & 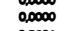 & 年. & 0.0000 & 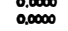 & $\begin{array}{l}3.0000 \\
0.000\end{array}$ & $\begin{array}{l}0.02 \\
0.00\end{array}$ & $\begin{array}{l}0.0 \\
0.0\end{array}$ & 0.0000 \\
\hline & (5) & . & $\begin{array}{l}0.0000 \\
0.0000\end{array}$ & $\begin{array}{l}0.0578 \\
0.0578\end{array}$ & $\begin{array}{l}0.00070 \\
0.0070\end{array}$ & $\begin{array}{l}0.0030 \\
0.0050\end{array}$ & $\begin{array}{l}0.0,0 \\
0.0 x\end{array}$ & 002 & $\begin{array}{l}0.0000 \\
0.0031\end{array}$ & 0.0028 & $\infty$ & $\begin{array}{l}0.0000 \\
0.0005\end{array}$ \\
\hline ses & $\infty$ & 0.0018 & 0.0000 & 0.0011 & 0.0005 & 0.0005 & 0.0024 & 0.0001 & 0.0000 & 0,0012 & 0.0000 & 0 \\
\hline & & $\begin{array}{l}0.0000 \\
0.000\end{array}$ & 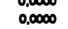 & $\begin{array}{l}0.0000 \\
0.0000\end{array}$ & $\begin{array}{l}0.0000 \\
0.0000 \\
0.00\end{array}$ & $\begin{array}{l}0.0002 \\
0.0000\end{array}$ & $\begin{array}{l}0.00000 \\
0.0000\end{array}$ & $\begin{array}{l}0.0000 \\
0.0000\end{array}$ & $\begin{array}{l}0.0000 \\
0.0000\end{array}$ & $\begin{array}{l}0.0000 \\
0.0000\end{array}$ & $\begin{array}{l}0.0000 \\
0.0000\end{array}$ & $\begin{array}{l}0.0001 \\
0.0000\end{array}$ \\
\hline & & 0.0000 & 0.0000 & 0.0000 & 0.0000 & 0.0000 & 0.00000 & 0000 & 0.0000 & 0.0000 & & \\
\hline ש. & $\begin{array}{l}72 \\
73\end{array}$ & $\begin{array}{l}0.0000 \\
0.0141\end{array}$ & $\begin{array}{l}0.0000 \\
0.000\end{array}$ & 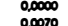 & $\begin{array}{l}0.10000 \\
0.0000\end{array}$ & 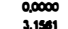 & 0.00 & 0.0000 & 0.0000 & 0.0000 & $\infty$ & 0.0000 \\
\hline & In & 0.00007 & 0.0000 & 0.0001 & 0.0000 & 0.0000 & 0.0000 & $\infty$ & 0.0000 & 0.0000 & 0.0000 & $\begin{array}{l}0.0003 \\
0.0003\end{array}$ \\
\hline 0000 & $\begin{array}{l}76 \\
70\end{array}$ & $\begin{array}{l}0.0001 \\
0.0001\end{array}$ & $\begin{array}{l}0.0000 \\
0.0000\end{array}$ & $\begin{array}{l}0.0000 \\
.00001\end{array}$ & $\begin{array}{l}0.0000 \\
0.0001\end{array}$ & $\begin{array}{l}0.0003 \\
0.0004 \\
0.004\end{array}$ & $\begin{array}{l}0.0011 \\
0.0001\end{array}$ & 18 & $\begin{array}{l}0.004 \\
0.0173\end{array}$ & D. 0.0105 & 0.0004 & 0 \\
\hline & 7 & 0.0017 & 0.0000 & o.0004 & c.0009 & 0.0151 & 0.0187 & 0014 & 0.0000 & 0.1225 & 0.051 & 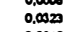 \\
\hline & 70 & 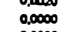 & 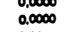 & $\begin{array}{l}0.0000 \\
0,0000\end{array}$ & $\begin{array}{l}0.0000 \\
0.0000\end{array}$ & $\begin{array}{l}0.0000 \\
0.0000\end{array}$ & $\begin{array}{l}0.0000 \\
0.0020 \\
0.00\end{array}$ & $\begin{array}{l}0.0001 \\
0.0000\end{array}$ & $\begin{array}{l}0.020 \\
0.0001\end{array}$ & $\begin{array}{l}0.0007 \\
0.0000\end{array}$ & $\begin{array}{l}0.0000 \\
0.0000\end{array}$ & $\begin{array}{l}0.0010 \\
0.0077\end{array}$ \\
\hline$c_{0}$ & $\begin{array}{l}\infty \\
81\end{array}$ & $\begin{array}{l}0.0000 \\
0.0000\end{array}$ & $\begin{array}{l}0.0000 \\
0.0000 \\
0.00\end{array}$ & $\begin{array}{l}0.0000 \\
0.0000\end{array}$ & $\begin{array}{l}0.0000 \\
0.0000\end{array}$ & $\begin{array}{l}0.0000 \\
0.0000 \\
0.000\end{array}$ & $\begin{array}{l}0.0000 \\
0.000\end{array}$ & $\begin{array}{l}\infty \\
\infty\end{array}$ & $\begin{array}{l}0.0000 \\
0.000 \\
0.000\end{array}$ & 0.0000 & $\begin{array}{l}0.000 \\
0.000 \\
0.000\end{array}$ & 0.0000 \\
\hline$n$ & * & 0.00000 & 0.0000 & 0,0000 & 0.00000 & 0.0000 & 0.0000 & 0.0000 & $\begin{array}{l}0.0000 \\
0.000\end{array}$ & 0.0000 & 0.0000 & 0.00 \\
\hline 等 & $\begin{array}{l}\infty \\
a\end{array}$ & $\begin{array}{l}0.0000 \\
0.0000\end{array}$ & $\begin{array}{l}0.0000 \\
0.0000\end{array}$ & $\begin{array}{l}0.0000 \\
0.0000\end{array}$ & $\begin{array}{l}0.0000 \\
0.0000\end{array}$ & $\begin{array}{l}0.0000 \\
0.0000\end{array}$ & $\begin{array}{l}0.00000 \\
0.0000 \\
0\end{array}$ & 0.0000 & $\begin{array}{l}0.0000 \\
0.0000 \\
0.000\end{array}$ & $\begin{array}{l}0.0000 \\
0.00000\end{array}$ & $\begin{array}{l}0,0000 \\
0.0000 \\
0.00\end{array}$ & 0.0000 \\
\hline 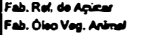 & $\begin{array}{l}25 \\
\text { as }\end{array}$ & $\begin{array}{l}0.0000 \\
0.00000\end{array}$ & $\begin{array}{l}0.0000 \\
0.0000\end{array}$ & $\begin{array}{l}0.0000 \\
.00000\end{array}$ & $\begin{array}{l}0.0000 \\
0.0000 \\
0.000\end{array}$ & $\begin{array}{l}0.0000 \\
0.0000 \\
0.000\end{array}$ & $\begin{array}{l}0,00000 \\
0,00000\end{array}$ & 0.0000 & $\begin{array}{l}0.0000 \\
0.0000 \\
0.000\end{array}$ & $\begin{array}{l}0.0007 \\
0.0010\end{array}$ & $\begin{array}{l}0.0000 \\
0.0000 \\
0.00\end{array}$ & $\begin{array}{l}0.0000 \\
0.0001 \\
0.001\end{array}$ \\
\hline & 87 & o. 0.0000 & 0.0000 & ocoso & 0.0000 & conos & 0.0 & 0.0000 & 0.0000 & 0.0 & $\infty$ & 0.0000 \\
\hline 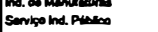 & 象 & $\begin{array}{l}0.0000 \\
0.0000 \\
0.000\end{array}$ & $\begin{array}{l}0.0000 \\
0.0000\end{array}$ & $\begin{array}{l}0.00000 \\
0.0000\end{array}$ & $\begin{array}{l}0.0000 \\
0.0000\end{array}$ & $\begin{array}{l}0.0000 \\
0.0000\end{array}$ & $\begin{array}{l}0.00000 \\
0,0000\end{array}$ & $\begin{array}{l}0.0000 \\
0.0000 \\
0.000\end{array}$ & $\begin{array}{l}0.0000 \\
0.0000\end{array}$ & 0.0000 & $\begin{array}{l}0.0000 \\
0.0000\end{array}$ & $\begin{array}{l}0.0000 \\
0.00000 \\
0.00\end{array}$ \\
\hline$=0 \mathrm{Cm}$ & $\stackrel{\infty}{\infty}$ & $\begin{array}{c}0.0000 \\
0000\end{array}$ & $\begin{array}{l}0.0000 \\
0.000 \\
0.00\end{array}$ & $\begin{array}{l}0.0000 \\
0.00000\end{array}$ & 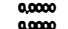 & 然 0.0000 & 0.0 & $m$ & 0.0000 & & 必 & 告 000000 \\
\hline & 02 & 0.00 & 0.0000 & 0.0000 & 0.0000 & 0,0000 & 0.0000 & 0.0000 & $\begin{array}{l}0.0000 \\
0.0000\end{array}$ & 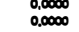 & $\infty$ & $\begin{array}{l}0.00 \\
0.02\end{array}$ \\
\hline & & & 0.0000 & 0.0 & $\frac{0.0000}{72100}$ & & & & & & 0 & 00008 \\
\hline & of & 0.0100 & 0.0000 & 0,000 & 0.0000 & & & & & & & \\
\hline & $\infty$ & 0.00 & $\infty \infty \infty$ & 0.0000 & 0.0000 & 0.0 & & 0.0000 & & & & \\
\hline Whe Batece & 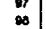 & $\begin{array}{l}0.1700 \\
0.1100\end{array}$ & $\begin{array}{l}0.0000 \\
0.0000\end{array}$ & $\begin{array}{l}0.500 \\
0.4700\end{array}$ & $\begin{array}{l}0.0000 \\
0.0000 \\
0.200\end{array}$ & $\begin{array}{l}0,400 \\
0.0000 \\
0.000\end{array}$ & $\begin{array}{l}0.00000 \\
0.02000\end{array}$ & 我 & $\begin{array}{l}0.0700 \\
0.00000\end{array}$ & $\begin{array}{l}0 \\
6\end{array}$ & 我 & 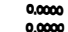 \\
\hline & & 0 & o.0000 & 00 & $10 \mathrm{sen}$ & & & $\infty$ & & & & 07 \\
\hline & 101 & $\begin{array}{l}.1 .000 \\
0.0000\end{array}$ & $\begin{array}{l}0.0000 \\
0.0000\end{array}$ & $\begin{array}{l}0.12000 \\
0.0000\end{array}$ & $\begin{array}{l}0.0000 \\
0.00000\end{array}$ & $\begin{array}{l}2,1,00000 \\
0.0000\end{array}$ & $\begin{array}{l}0.07000 \\
0.00000\end{array}$ & $\begin{array}{l}0.1000 \\
0.0000\end{array}$ & $\begin{array}{l}0.0000 \\
0.0000\end{array}$ & & & 0.0 \\
\hline & 102 & $\begin{array}{l}0.0000 \\
0.0000 \\
0.000\end{array}$ & o.0000 & 1.0000 & 0.0000 & o. 0.000 & & 0.0000 & 0.0500 & 0.0000 & 0.00000 & 0.0 \\
\hline 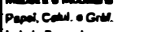 & 100 & 年 & 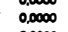 & 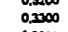 & 12000 & 35.,0000 & $\begin{array}{l}0.0 \\
0.2\end{array}$ & 0.0000 & $\begin{array}{l}0.0 .0500 \\
0.1100\end{array}$ & $\begin{array}{l}0.1000 \\
0.0000 \\
0\end{array}$ & $\begin{array}{l}0.0000 \\
0.00000\end{array}$ & \\
\hline & $\begin{array}{l}105 \\
100\end{array} \mid$ & $\begin{array}{l}0.0000 \\
0.1100\end{array}$ & $\begin{array}{l}0.0000 \\
0.00000\end{array}$ & 0.1700 & $\begin{array}{l}0.1500 \\
0.17700\end{array}$ & $\begin{array}{l}0.3100 \\
22000 \\
2000\end{array}$ & $\begin{array}{l}0.00000 \\
0.00000\end{array}$ & $\begin{array}{l}0.05000 \\
i, 0000\end{array}$ & $\begin{array}{l}0.0000 \\
0.0000\end{array}$ & $\begin{array}{l}0.2000 \\
0 ., 3500\end{array}$ & $\begin{array}{l}0.1000 \\
0.0500\end{array}$ & 0 \\
\hline & $\begin{array}{l}107 \\
100\end{array} \mid$ & $\begin{array}{l}0.0000 \\
0.05500\end{array}$ & . $\begin{array}{l}0.00000 \\
0.00000\end{array}$ & $\begin{array}{l}0.0000 \\
0.00000 \\
0.700\end{array}$ & $\begin{array}{l}1,14000 \\
207000\end{array}$ & & .4. & $\begin{array}{l}0.2000 \\
0.00700\end{array}$ & $\begin{array}{l}15.0000 \\
0.000\end{array}$ & 32200 & & o \\
\hline h & $\begin{array}{c}100 \\
110\end{array} \mid$ & $\begin{array}{l}12000 \\
0.00100\end{array}$ & 0.0000 & $\begin{array}{l}0.0000 \\
0.1000 \\
0.1000\end{array}$ & 0.0550 & 烈 & $\begin{array}{l}0.0400 \\
0.0000\end{array}$ & 0,1000 & $\begin{array}{l}0.000 \\
0.000 \\
0.000\end{array}$ & 8.7 & $\begin{array}{l}0.1200 \\
i=00\end{array}$ & 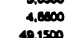 \\
\hline & 111 & 0.0000 & 0.0000 & 0 & 0.0000 & $\begin{array}{l}0.0000 \\
0.00000\end{array}$ & 0.0000 & $\begin{array}{l}0.01000 \\
0.00000\end{array}$ & 0 & $\begin{array}{l}0.4 \\
0.9\end{array}$ & 象, 0000 & 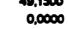 \\
\hline & $\begin{array}{l}112 \\
112\end{array}$ & 0.00 & 然.00000 & 0.00 & 0.0 & & & 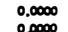 & 0.0 & & & 0.00 \\
\hline & 114 | & $\begin{array}{l}0.0 \\
0.0\end{array}$ & 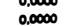 & $\begin{array}{l}0.0 \\
0.0\end{array}$ & & & & 0.0000 & & & & 0.0 \\
\hline encinst & 115 & 0.0000 & 0.00000 & 0.0000 & 0,00000 & 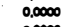 & . & 0.0000 & 0.0000 & & 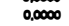 & \\
\hline 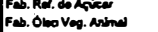 & 1178 & $\begin{array}{l}0.0000 \\
0.0000\end{array}$ & $\begin{array}{l}0.0000 \\
0.00000\end{array}$ & $\begin{array}{l}0.0000 \\
0.0000\end{array}$ & $\begin{array}{l}0,0000 \\
0,00000\end{array}$ & $\begin{array}{l}0.0000 \\
0.0000\end{array}$ & $\begin{array}{l}0.00000 \\
0.00000\end{array}$ & 0 & $\begin{array}{l}0.0000 \\
0.0000\end{array}$ & $\begin{array}{l}0.5 \\
.1 .1\end{array}$ & $\begin{array}{l}0.0000 \\
0.0000\end{array}$ & $\begin{array}{l}0.0000 \\
00000\end{array}$ \\
\hline 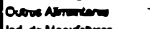 & $\cdots$ & D. & 0.00000 & 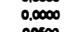 & 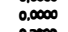 & $3=$ & 0,0 & 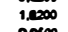 & 0.0000 & & 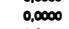 & ram \\
\hline 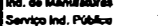 & in & $\begin{array}{l}0.13000 \\
0.70000\end{array}$ & $\begin{array}{l}0,0000 \\
0.00000\end{array}$ & $\begin{array}{l}0.0500 \\
0.55000\end{array}$ & 0.2 & 0. & & 0.0500 & $\begin{array}{l}0.1000 \\
0.2000\end{array}$ & & $\infty$ & 0,4 \\
\hline & . & 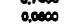 & m. & 0.00000 & 0.1700 & 0.100 & 0.0700 & 0.0000 & 0.0000 & 禹, & $\infty$ & 0.27 \\
\hline & 122 & 148400 & 0.0000 & 7,1 & 5,0000 & 22,900 & 4,220 & 10000 & 2,00000 & 37.6 & .5000 & 23.0100 \\
\hline & $\mid$ & 22000 & & 4.0000 & $\begin{array}{l}12000 \\
8.1000\end{array}$ & $\begin{array}{l}2.0500 \\
8.000\end{array}$ & 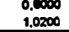 & $\begin{array}{l}23000 \\
122000\end{array}$ & $\begin{array}{l}3.250 \\
4.12200\end{array}$ & $\begin{array}{l}2.221000 \\
222500\end{array}$ & $\begin{array}{l}0.67700 \\
277000\end{array}$ & $\begin{array}{r}.471700 \\
010,1000\end{array}$ \\
\hline & & 3 & 0.0 & 53,0 & & 005.65 & & 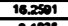 & 87.0028 & 168.1 & $\frac{217}{21}$ & $\frac{20 x}{20}$ \\
\hline 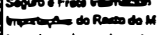 & 127 & 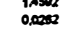 & 0.0000 & 0.1177 & 3.0787 & 0.5247 & 0.58504 & $\begin{array}{l}0,01208 \\
2275\end{array}$ & 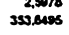 & SS,A40s & 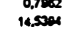 & $\begin{array}{l}20.0014 \\
20.6172\end{array}$ \\
\hline 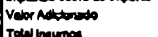 & 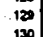 & $\stackrel{30,5148}{3}$ & $\begin{array}{l}0.0000 \\
0,000\end{array}$ & $\begin{array}{l}20,0581 \\
300006\end{array}$ & s,essi1 & 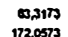 & 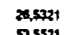 & 18.08141 & 20,15000 & 119.4152 & 2s,soso & 112,400 \\
\hline & & & & & & & & & & & & \\
\hline
\end{tabular}




\begin{tabular}{|c|c|c|c|c|c|c|c|c|c|c|c|}
\hline 年 & $\mathrm{Fo}$ & tרen & End is & $\pi+\infty$ & 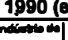 & 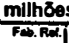 & . & asen & 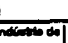 & $=0$ & 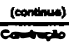 \\
\hline STs & & $\begin{array}{l}\text { cocono } \\
112\end{array}$ & mines & $\infty$ & 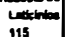 & 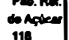 & 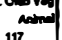 & הח & & 争 & CW1 \\
\hline & & & & & & 000 & & תח & D. & 000 & \\
\hline an & $\begin{array}{l}0.0000 \\
0.0000 \\
0.00\end{array}$ & $\begin{array}{l}0.0000 \\
0.000 \\
0.003\end{array}$ & $\begin{array}{l}0.0000 \\
0.0000\end{array}$ & $\begin{array}{l}0.0000 \\
0.0000\end{array}$ & $\begin{array}{l}0.0000 \\
0.0000\end{array}$ & $\begin{array}{l}0.0050 \\
0.0000\end{array}$ & $\begin{array}{l}0.0000 \\
0.0000\end{array}$ & $\begin{array}{l}0.0000 \\
0.0000\end{array}$ & $\begin{array}{l}0.0001 \\
0.0000\end{array}$ & $\begin{array}{l}0.000 \\
0.0000\end{array}$ & $\begin{array}{l}0.0000 \\
0.0000\end{array}$ \\
\hline 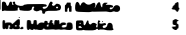 & $\begin{array}{l}0.0000 \\
0.0000\end{array}$ & $\begin{array}{l}0.0011 \\
0.00000\end{array}$ & $\begin{array}{l}0.0000 \\
0.012\end{array}$ & $\begin{array}{l}0.0000 \\
0.07004\end{array}$ & $\begin{array}{l}0.0000 \\
0.00010\end{array}$ & $\begin{array}{l}0.0000 \\
0.00000 \\
0.00\end{array}$ & $\begin{array}{l}0.0000 \\
0.00000 \\
0.000\end{array}$ & $\begin{array}{l}0.0000 \\
0.00173\end{array}$ & $\begin{array}{l}0.0000 \\
0.0070\end{array}$ & $\begin{array}{l}0.0000 \\
0.00173\end{array}$ & $\begin{array}{l}0.3000 \\
0.0070\end{array}$ \\
\hline & 0.0000 & 0.207 & 0.0074 & 0.0117 & 0.0450 & 0.0000 & 0.0000 & 0.0070 & 0.0207 & 0.00000 & 12205 \\
\hline ? & $\begin{array}{l}0.0000 \\
0.0000 \\
0.000\end{array}$ & $\begin{array}{l}0.000 \\
0.0000 \\
0.000\end{array}$ & $\begin{array}{l}0,0000 \\
0.0000\end{array}$ & $\begin{array}{l}0.0170 \\
0.00000\end{array}$ & $\begin{array}{l}0.0000 \\
0.00000\end{array}$ & $\begin{array}{l}0.057 \\
0.00000\end{array}$ & $\begin{array}{l}0.0000 \\
0.0000 \\
0.00\end{array}$ & $\begin{array}{l}0.00000 \\
0.00000\end{array}$ & $\begin{array}{l}0.0000 \\
0.0000\end{array}$ & $\begin{array}{l}0.01406 \\
0.0000\end{array}$ & $\begin{array}{l}1.06306 \\
0.0000\end{array}$ \\
\hline io & $\begin{array}{l}0.0000 \\
0.00000\end{array}$ & $\begin{array}{l}0.0000 \\
0.00000\end{array}$ & $\begin{array}{l}0.047 \\
0.0000\end{array}$ & $\begin{array}{l}0.0000 \\
0.00000\end{array}$ & $\begin{array}{l}0.0000 \\
000000 \\
0\end{array}$ & $\begin{array}{l}0.0000 \\
0.00000 \\
0.00\end{array}$ & $\begin{array}{l}0.0000 \\
0.0000 \\
0.000\end{array}$ & $\begin{array}{l}0.00000 \\
0.0002\end{array}$ & $\begin{array}{l}0.0000 \\
0.0000\end{array}$ & $\begin{array}{l}0.00000 \\
0.00000\end{array}$ & $\begin{array}{l}0.0000 \\
0.0577\end{array}$ \\
\hline Ma.orate. & 0.0002 & 0.050 & 0.000 & 02000 & 0.0000 & 0,0000 & 000000 & 0.2000 & 0.0000 & 0.0000 & 0.014 \\
\hline 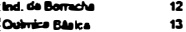 & $\begin{array}{l}0.0000 \\
0.00000\end{array}$ & $\begin{array}{l}0.0403 \\
202000\end{array}$ & $\begin{array}{l}0.018 \\
0.0017\end{array}$ & 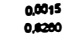 & $\begin{array}{l}0.0135 \\
0.0011\end{array}$ & $\begin{array}{l}0.0015 \\
0.0027\end{array}$ & $\begin{array}{l}0.0000 \\
0.0000 \\
0.000\end{array}$ & $\begin{array}{l}0.0045 \\
0.0060\end{array}$ & $\begin{array}{l}0.0000 \\
0.0187\end{array}$ & $\begin{array}{l}0.00221 \\
0.00000\end{array}$ & $\begin{array}{l}0.0001 \\
0.0000\end{array}$ \\
\hline 悉 & $\begin{array}{l}0.0214 \\
0.000\end{array}$ & 0.52121 & $\begin{array}{l}02225 \\
0.225\end{array}$ & 02224 & 然 & 0.0147 & תמת & 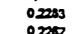 & 0.0071 & 0.5718 & 0.4200 \\
\hline 16 & 0 & 0.2356 & 0.0000 & $\begin{array}{l}0.0020 \\
0.0551\end{array}$ & $\begin{array}{l}0.10100 \\
0.61800\end{array}$ & $\begin{array}{l}0.000 \\
0.2162\end{array}$ & $\begin{array}{l}0.0000 \\
0.0000\end{array}$ & 0,0000 & 然 & $\begin{array}{l}0.0000 \\
0.0000\end{array}$ & $\begin{array}{l}0.0000 \\
0.0000\end{array}$ \\
\hline 17 & $\begin{array}{l}2002 \\
0.0000 \\
0.000\end{array}$ & $\begin{array}{l}0.8064 \\
0.0000\end{array}$ & $\begin{array}{l}0.0255 \\
0.00000\end{array}$ & $\begin{array}{l}0.0002 \\
0.0000 \\
0.000\end{array}$ & $\begin{array}{l}0.0000 \\
0.00000\end{array}$ & $\begin{array}{l}0.1500 \\
0.0000\end{array}$ & $\begin{array}{l}0.0000 \\
0.00000\end{array}$ & $\begin{array}{l}0.02011 \\
0.00000\end{array}$ & $\begin{array}{l}0.5050 \\
0.0000\end{array}$ & $\begin{array}{l}0.0100 \\
0.00000\end{array}$ & $\begin{array}{l}0,0000 \\
0.0000 \\
0.000\end{array}$ \\
\hline 10 & $\begin{array}{l}4.6101 \\
0.000\end{array}$ & $\begin{array}{l}1,1, s e c 1 \\
0,0000\end{array}$ & $\begin{array}{l}0.0000 \\
0.0000\end{array}$ & $\begin{array}{l}0.0000 \\
0.0000\end{array}$ & $\begin{array}{l}0.0000 \\
0.0000\end{array}$ & $\begin{array}{l}0.0000 \\
0.0000 \\
0.000\end{array}$ & 年 & $\begin{array}{l}0,0000 \\
0,0000\end{array}$ & $\begin{array}{l}0.0000 \\
0.0000 \\
0.000\end{array}$ & $\begin{array}{l}0.0000 \\
0.000 \\
0.00\end{array}$ & o, 0000 \\
\hline 21 & 0.0000 & 0,0501 & 0.0000 & 0.18000 & 象 & 0.0000 & 0.0000 & 0.00000 & 我, 00000 & 0.0000 & 0.0000 \\
\hline$\frac{22}{20}$ & $\begin{array}{l}0.0000 \\
0.0000 \\
0.00\end{array}$ & $\begin{array}{l}0.0000 \\
0.0000\end{array}$ & $\begin{array}{l}0.0000 \\
0.0000\end{array}$ & $\begin{array}{l}0.0000 \\
0.00000 \\
0.00\end{array}$ & $\begin{array}{l}0.0000 \\
0.0000\end{array}$ & $\begin{array}{l}0.0000 \\
0.00000\end{array}$ & $\begin{array}{l}0.0000 \\
0.00000\end{array}$ & 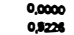 & $\begin{array}{l}0,0000 \\
0.00000 \\
0.000\end{array}$ & $\begin{array}{l}0.00000 \\
0.00000\end{array}$ & $\begin{array}{l}0.0000 \\
0.0000\end{array}$ \\
\hline $\begin{array}{l}24 \\
25\end{array}$ & $\begin{array}{l}0.0000 \\
0.0000\end{array}$ & 年 & $\begin{array}{l}0.0000 \\
0.0070\end{array}$ & $\begin{array}{l}0.0000 \\
0.0001\end{array}$ & $\begin{array}{l}0.0000 \\
0.0000 \\
0.000\end{array}$ & $\begin{array}{l}0.0000 \\
0.0000\end{array}$ & $\begin{array}{l}3.0518 \\
0.0058\end{array}$ & $\begin{array}{l}0.0700 \\
0.071702\end{array}$ & $\begin{array}{l}0.0000 \\
0.000\end{array}$ & $\begin{array}{l}0.0000 \\
0.000 \\
0.000\end{array}$ & $\begin{array}{l}0.0000 \\
0.000\end{array}$ \\
\hline תמש & 0.0005 & 0.0019 & 0.0000 & 0,0000 & 0.0000 & 0.0000 & 0.0000 & 0.0000 & 0.0002 & 0.0000 & 0.0000 \\
\hline 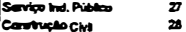 & $\begin{array}{l}0.0000 \\
0.0000\end{array}$ & $\begin{array}{l}0.0000 \\
0.0000\end{array}$ & $\begin{array}{l}0.0000 \\
0.0000\end{array}$ & $\begin{array}{l}0.0000 \\
0.00000\end{array}$ & $\begin{array}{l}0.0000 \\
0.0000\end{array}$ & $\begin{array}{l}0.0000 \\
0.00000\end{array}$ & $\begin{array}{l}0.0000 \\
0.00000 \\
0.00\end{array}$ & $\begin{array}{l}0.00000 \\
0.0000\end{array}$ & $\begin{array}{l}0.0000 \\
0.0000\end{array}$ & $\begin{array}{l}0.0000 \\
0.00000\end{array}$ & $\begin{array}{l}0.0000 \\
0.0000\end{array}$ \\
\hline 20 & 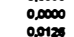 & $\begin{array}{l}0.0000 \\
0.0117 \\
0.017\end{array}$ & $\begin{array}{l}0.0000 \\
0.0050\end{array}$ & $\begin{array}{l}0,0000 \\
0.0000 \\
0.040\end{array}$ & $\begin{array}{l}0.0000 \\
0.0000 \\
0.000\end{array}$ & $\begin{array}{l}0.0000 \\
00000 \\
0.000\end{array}$ & $\begin{array}{l}0,0000 \\
0.000 \\
0000\end{array}$ & $\begin{array}{l}0.0000 \\
0.070\end{array}$ & $\begin{array}{l}0.0000 \\
0.0000\end{array}$ & $\begin{array}{l}0.0000 \\
0.0000\end{array}$ & $\begin{array}{l}0.0000 \\
0.0000\end{array}$ \\
\hline & 0.0001 & 0.0001 & & 0.0000 & 0.0000 & 告.0000 & 然, 00000 & 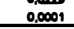 & $\mathrm{m}^{2}$ & 0.0000 & 0.0000 \\
\hline Co Mtren & $\begin{array}{l}0.0000 \\
0.00000\end{array}$ & $\begin{array}{l}0.3700 \\
0.0010\end{array}$ & $\begin{array}{l}7.1007 \\
0.0000\end{array}$ & $\begin{array}{l}0.0000 \\
0.00000\end{array}$ & $\begin{array}{l}0.0000 \\
0.00000\end{array}$ & $\begin{array}{l}0.0000 \\
0.01214\end{array}$ & $\begin{array}{l}0.0000 \\
0.0000\end{array}$ & 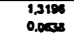 & $\begin{array}{l}0.0022 \\
0.0004\end{array}$ & $\begin{array}{l}0.00000 \\
0.00000\end{array}$ & $\begin{array}{l}0.0000 \\
0.0000\end{array}$ \\
\hline 35 & $\begin{array}{l}0.0000 \\
0.000 \\
0.000\end{array}$ & $\begin{array}{l}0.0000 \\
0.00001\end{array}$ & $\begin{array}{l}0.0000 \\
0.0000\end{array}$ & $\begin{array}{l}0.0000 \\
0.000\end{array}$ & $\begin{array}{l}0.0000 \\
0.0000 \\
0.000\end{array}$ & $\begin{array}{l}0.0000 \\
0.0000 \\
0.000\end{array}$ & $\begin{array}{l}0.0000 \\
0.0000\end{array}$ & $\begin{array}{l}0.0000 \\
0.0000\end{array}$ & $\begin{array}{l}0.0000 \\
0.00107\end{array}$ & $\begin{array}{l}0.0000 \\
0.0000\end{array}$ & $\begin{array}{l}0.0000 \\
0.42828\end{array}$ \\
\hline 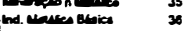 & 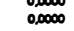 & 0 & 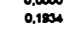 & $\begin{aligned} 0.000 \\
0.1112\end{aligned}$ & 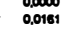 & $\begin{array}{l}0.0000 \\
0.0000\end{array}$ & 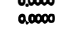 & 年 & 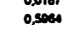 & 0.770 & 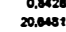 \\
\hline 37 & $\begin{array}{l}0.0000 \\
0.000\end{array}$ & $\begin{array}{l}0.2003 \\
0.0000\end{array}$ & $\begin{array}{l}0.123 \\
0.0000\end{array}$ & 盗 & $\begin{array}{l}0.0500 \\
00000\end{array}$ & $\begin{array}{l}0.0000 \\
0.000 \\
0\end{array}$ & 象 & 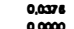 & $\begin{array}{l}0.02000 \\
0.0015\end{array}$ & $\begin{array}{l}0.0000 \\
0 \times 050 \\
0 \times 30\end{array}$ & 1.7080 \\
\hline$\infty$ & 0.0000 & 0.0000 & 0.0000 & 0.0000 & 0.0000 & 0.0000 & 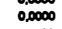 & 0.0000 & . & 0.0000 & $\begin{array}{l}3.0000 \\
0.000\end{array}$ \\
\hline 41 & $\begin{array}{l}0.0000 \\
0.00000\end{array}$ & $\begin{array}{l}0.0000 \\
0.0000\end{array}$ & $\begin{array}{l}\begin{array}{r}0.3054 \\
0.0000\end{array} \\
0.000\end{array}$ & $\begin{array}{l}0.0000 \\
0.00000 \\
0.00\end{array}$ & $\begin{array}{l}0.0000 \\
0.00000\end{array}$ & 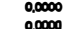 & $\begin{array}{l}0.0000 \\
0.0000 \\
0.000\end{array}$ & $\infty$ & $\begin{array}{l}0.0000 \\
0.0000 \\
0.000\end{array}$ & $\begin{array}{l}0,0000 \\
0,0000\end{array}$ & 0 \\
\hline locare. & 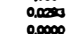 & $\begin{array}{l}0217 \\
0.217 \\
0.500\end{array}$ & $\begin{array}{l}2,1007 \\
0,2000\end{array}$ & 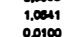 & $\begin{array}{l}0.0606 \\
0.0000\end{array}$ & $\begin{array}{l}0.000 \\
0.0000 \\
0.000\end{array}$ & $\begin{array}{l}0,0000 \\
0.000 \\
0,000\end{array}$ & 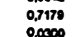 & $\begin{array}{l}0.0000 \\
0.0000 \\
0.000\end{array}$ & & 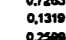 \\
\hline 4 & $\begin{array}{l}0.0000 \\
0.0000 \\
.000\end{array}$ & 1.12203 & 年 & $\begin{array}{l}0.0100 \\
0.0112\end{array}$ & $\begin{array}{l}0.0000 \\
0.0000\end{array}$ & $\begin{array}{l}0.01000 \\
0.0130\end{array}$ & $\begin{array}{l}0.0000 \\
0.0000\end{array}$ & 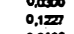 & $\begin{array}{l}0.0000 \\
0.0074\end{array}$ & $\begin{array}{l}0.07000 \\
0.0000\end{array}$ & 0.0000 \\
\hline${ }_{40}^{45}$ & $\begin{array}{l}0.0010 \\
0.00000\end{array}$ & $\begin{array}{l}0.0733 \\
0.7022\end{array}$ & $\begin{array}{l}0.0112 \\
02000\end{array}$ & $\begin{array}{l}0.0158 \\
0.11105\end{array}$ & $\begin{array}{l}0.04016 \\
0.0200\end{array}$ & $\begin{array}{l}0.0006 \\
0.0000\end{array}$ & $\begin{array}{l}0.0016 \\
0.00000\end{array}$ & $\begin{array}{l}0.0105 \\
02170\end{array}$ & $\begin{array}{l}0.0000 \\
0.0754\end{array}$ & $\begin{array}{l}0.0028 \\
0.0175\end{array}$ & $\begin{array}{l}0.01100 \\
0.00000\end{array}$ \\
\hline 48 & 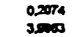 & $\begin{array}{l}0.3551 \\
0.5522\end{array}$ & $\begin{array}{l}0.0000 \\
1.074 \pi\end{array}$ & 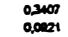 & $\begin{array}{l}0.7110 \\
0.0000\end{array}$ & $\begin{array}{l}0.2918 \\
0.2770\end{array}$ & $\begin{array}{l}0.0000 \\
0.0000\end{array}$ & $\begin{array}{l}0.0000 \\
0.0004\end{array}$ & $\begin{array}{l}0.006 \\
0.00000 \\
0.000\end{array}$ & $\begin{array}{l}0.000 \\
0.0078 \\
0.078\end{array}$ & $\begin{array}{l}0.0000 \\
0.00000\end{array}$ \\
\hline & & $\begin{array}{l}0.0000 \\
0.5111\end{array}$ & $\begin{array}{l}0.0000 \\
0.00000 \\
0.00\end{array}$ & $\begin{array}{l}0.0000 \\
0.00000 \\
0.000\end{array}$ & $\begin{array}{l}0,0000 \\
00000 \\
0.000\end{array}$ & $\begin{array}{l}0.0000 \\
00000\end{array}$ & $\begin{array}{l}0.0000 \\
00000\end{array}$ & $\begin{array}{l}0.0000 \\
0.0000\end{array}$ & $\begin{array}{l}0.0000 \\
0.000\end{array}$ & $\begin{array}{l}0.0000 \\
0.005\end{array}$ & $\begin{array}{l}0.0000 \\
0.000\end{array}$ \\
\hline 51 & 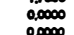 & $\begin{array}{l}0.0000 \\
0.215\end{array}$ & 0.0000 & 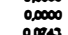 & $\begin{array}{l}0.0000 \\
0,000\end{array}$ & $\begin{array}{l}0.0000 \\
0.0000\end{array}$ & .0000 & 0.0000 & $\begin{array}{l}0.0000 \\
0.0000\end{array}$ & $\begin{array}{l}0.0000 \\
0.000\end{array}$ & 0.0000 \\
\hline 70 & 0.0000 & 0.0000 & $\begin{array}{l}0.0000 \\
0.000 \\
0.00\end{array}$ & $\begin{array}{l}0.0000 \\
0.0000\end{array}$ & 0.00000 & 0.0000 & 0.0000 & 0.0000 & 0.0000 & 0.0000 & $\begin{array}{l}0.0000 \\
0.0000\end{array}$ \\
\hline 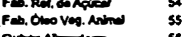 & 年 & $\begin{array}{l}0.005 \\
0.0005 \\
0\end{array}$ & $\begin{array}{l}0.0000 \\
0.0000 \\
0.000\end{array}$ & $\begin{array}{l}0.00000 \\
0.0000\end{array}$ & $\begin{array}{l}0.0000 \\
0.0000\end{array}$ & $\begin{array}{l}0.0000 \\
0.0000\end{array}$ & $\begin{array}{l}0.0000 \\
2018\end{array}$ & $\begin{array}{l}0.0531 \\
0.0532\end{array}$ & $\begin{array}{l}0.000 \\
0.0000\end{array}$ & $\begin{array}{l}0.0000 \\
0.0000 \\
0.000\end{array}$ & $\begin{array}{l}0.0000 \\
0.0000\end{array}$ \\
\hline${ }_{58}^{56}$ & $\begin{array}{l}0.0000 \\
0.0130\end{array}$ & $\begin{array}{l}0.0000 \\
0.0486\end{array}$ & $\begin{array}{l}0.0020 \\
0.0000\end{array}$ & $\begin{array}{l}0.0008 \\
0.0000 \\
0.000\end{array}$ & $\begin{array}{l}0.0000 \\
0.0000\end{array}$ & $\begin{array}{l}0.0000 \\
0.0000\end{array}$ & $\begin{array}{l}0.0018 \\
0.0000\end{array}$ & $\begin{array}{l}0.0 .0007 \\
0.0000\end{array}$ & 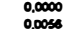 & $\begin{array}{l}0.0000 \\
00000\end{array}$ & $\begin{array}{l}0.0000 \\
0.0000\end{array}$ \\
\hline so & 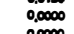 & . 0.0000 & 0.0000 & 0.0000 & . 0.0000 & 年 & 0.0000 & 然.0000 & $\begin{array}{l}0.0000 \\
0.000\end{array}$ & 0.0000 & 0.0000 \\
\hline si & 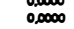 & 0.0000 & $\begin{array}{l}0.000 \\
0.000 \\
0.000\end{array}$ & $\begin{array}{l}0.0000 \\
0.0000\end{array}$ & $\begin{array}{l}0.0000 \\
0.0000\end{array}$ & $\begin{array}{l}0.0000 \\
0.0000\end{array}$ & $\begin{array}{l}0.0000 \\
0.0000\end{array}$ & $\begin{array}{l}0.0000 \\
0.0000\end{array}$ & $\begin{array}{l}0.0000 \\
0.0000\end{array}$ & $\begin{array}{l}0.0000 \\
0.0000\end{array}$ & $\begin{array}{l}0.0000 \\
0.0000\end{array}$ \\
\hline $\begin{array}{ll}81 \\
02\end{array}$ & 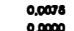 & $\begin{array}{l}0.0070 \\
0.0003 \\
0.00\end{array}$ & $\begin{array}{l}0.0005 \\
0.0001 \\
0.001\end{array}$ & $\begin{array}{l}0.0700 \\
0.0000 \\
0.00\end{array}$ & 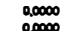 & $\begin{array}{l}0.0000 \\
0.000 \\
0.000\end{array}$ & 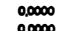 & 0.0137 & $\begin{array}{l}0.0000 \\
0.000\end{array}$ & $\begin{array}{l}0.0000 \\
0.000 \\
0.000\end{array}$ & 0.0000 \\
\hline 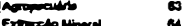 & 0.000 & 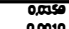 & 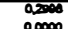 & 0.0000 & 0.0000 & 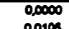 & 0.0000 & 0,1786 & 0.0002 & 0.0000 & $\frac{0.0000}{0.0000}$ \\
\hline as & 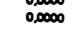 & 0.0000 & 0.0000 & 0.000 & 0.0000 & 0.0000 & 0.0000 & 0.0000 & 0.000 & 0.0 & $\begin{array}{l}0.0000 \\
0.0000 \\
0.00\end{array}$ \\
\hline 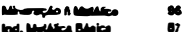 & o. 0000 & 0.0001 & 0.0000 & 0.0000 & o. 0.000 & 0.0000 & 0.0000 & & 0.0005 & & 0.0218 \\
\hline 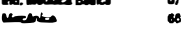 & 0.0000 & 0.0000 & 0.0000 & 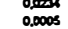 & 然 & $\begin{array}{l}0.0000 \\
0.000 \\
0.000\end{array}$ & $\begin{array}{l}0.0000 \\
0.0000\end{array}$ & $\begin{array}{l}0.0004 \\
0.0012\end{array}$ & $\begin{array}{l}0.0125 \\
0.0000\end{array}$ & 年, 0000 & $\begin{array}{l}0.4322 \\
0.0550\end{array}$ \\
\hline >0 & $\begin{array}{l}0.0000 \\
0.0000 \\
0.00\end{array}$ & $\begin{array}{l}0.0000 \\
0.0000 \\
0.00\end{array}$ & $\begin{array}{l}0.0000 \\
0.0000 \\
0.000\end{array}$ & 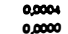 & $\begin{array}{l}0.0000 \\
0.0000 \\
0.00\end{array}$ & $\begin{array}{l}0.0001 \\
0.0000 \\
0.000\end{array}$ & $\begin{array}{l}0.0000 \\
0.0000 \\
0.000\end{array}$ & $\begin{array}{l}0.0000 \\
0.0000 \\
0.000\end{array}$ & $\begin{array}{l}0.0000 \\
0.0000 \\
0.000\end{array}$ & $\begin{array}{l}0.0000 \\
0.0000\end{array}$ & $\begin{array}{l}0.0002 \\
0.0000 \\
0.00\end{array}$ \\
\hline & 0.0000 & 0.0000 & 0.0000 & 0.0000 & 0.0000 & 0.0000 & 0.0000 & 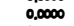 & 0.0000 & & 0.0000 \\
\hline Donde & $\begin{array}{l}0.0000 \\
0.0004\end{array}$ & $\begin{array}{l}0.0000 \\
0.0774\end{array}$ & $\begin{array}{l}0.0000 \\
0.0758\end{array}$ & $\begin{array}{l}0.0000 \\
0.373\end{array}$ & $\begin{array}{l}0.0000 \\
0.0005\end{array}$ & $\begin{array}{l}0.0000 \\
0.0000 \\
0.00\end{array}$ & $\begin{array}{l}0.0000 \\
0.0000\end{array}$ & $\begin{array}{l}0.0002 \\
0.000 \\
0.000\end{array}$ & $\begin{array}{l}0.0000 \\
0.000 \\
0.000\end{array}$ & $\begin{array}{l}0.0000 \\
0.0000\end{array}$ & $\begin{array}{l}0.011 \\
0.0122\end{array}$ \\
\hline את & o.0000 & 0.0000 & 0.0000 & 然 & 0.0001 & 0.0000 & 0.0000 & 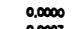 & 0.0000 & 0.0000 & 0.0004 \\
\hline 78 & 0.0001 & 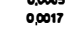 & 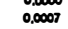 & $\begin{array}{l}0.0010 \\
0.0010\end{array}$ & $\begin{array}{l}0.0002 \\
0.0000\end{array}$ & 等 & $\begin{array}{l}0.0000 \\
0.0001\end{array}$ & $0 . x$ & $\begin{array}{l}0.0000 \\
0.0000\end{array}$ & 17 & $\begin{array}{l}0.0000 \\
0.0013\end{array}$ \\
\hline coper & $\begin{array}{l}0.0000 \\
0.0000\end{array}$ & $\begin{array}{l}0.0118 \\
0.0015\end{array}$ & $\begin{array}{l}0.0000 \\
0.0000 \\
0.000\end{array}$ & $\begin{array}{l}0.0025 \\
0.0013 \\
0.013\end{array}$ & $\begin{array}{l}0.0027 \\
0.0028\end{array}$ & $\begin{array}{l}0.0000 \\
0.0010\end{array}$ & $\begin{array}{l}0.0000 \\
0.0000 \\
0.000\end{array}$ & $\begin{array}{l}0.0052 \\
0.0000\end{array}$ & $\begin{array}{l}0.016 \\
0.0001\end{array}$ & 0.0000 & $\begin{array}{l}0.0000 \\
0.0000 \\
0.00\end{array}$ \\
\hline 70 & 然 & 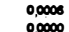 & 年. 0.0013 & 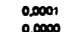 & 0.0000 & 0.00000 & 0.0000 & 0 & 0.0012 & 0.0000 & 0.0000 \\
\hline 央 & $\begin{array}{l}0.021 \\
0.0213\end{array}$ & $\begin{array}{l}0.0000 \\
0.0550\end{array}$ & $\begin{array}{l}0.0000 \\
0.0000\end{array}$ & $\begin{array}{l}0.0000 \\
0.0000\end{array}$ & $\begin{array}{l}0.0000 \\
0.0000\end{array}$ & $\begin{array}{l}0.0000 \\
0.0000\end{array}$ & $\begin{array}{l}0.0000 \\
0.0000\end{array}$ & $\begin{array}{l}0.0000 \\
0.0000\end{array}$ & $\begin{array}{l}0.0000 \\
0.0000\end{array}$ & $\begin{array}{l}0.0000 \\
0.0000\end{array}$ & $\begin{array}{l}0.0000 \\
0.0000 \\
0.00\end{array}$ \\
\hline \$ & $\begin{array}{l}0.0000 \\
0.0000 \\
0.000\end{array}$ & $\begin{array}{l}0.0000 \\
0.0050 \\
0.00\end{array}$ & $\begin{array}{l}0.0000 \\
0.0000\end{array}$ & 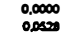 & $\begin{array}{l}0.0000 \\
0.0000 \\
0.000\end{array}$ & $\begin{array}{l}0.0000 \\
0.0000 \\
0.000\end{array}$ & $\begin{array}{l}0.0000 \\
0.0000 \\
0.000\end{array}$ & $\begin{array}{l}0.0000 \\
0.0000\end{array}$ & $\begin{array}{l}0.0000 \\
0.0000 \\
0.00\end{array}$ & $\begin{array}{l}0.00000 \\
0.0000\end{array}$ & $\begin{array}{l}0.0000 \\
0.0000 \\
0.00\end{array}$ \\
\hline 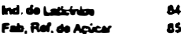 & $\begin{array}{l}0.0000 \\
0.0000\end{array}$ & $\begin{array}{l}0.0000 \\
0.0000\end{array}$ & $\begin{array}{l}0.0000 \\
0.0000 \\
0.00\end{array}$ & $\begin{array}{l}0.0000 \\
0.0000\end{array}$ & $\begin{array}{l}0.0008 \\
0.0000 \\
0.00\end{array}$ & $\begin{array}{l}0.000 \\
0.000 \\
0.000\end{array}$ & $\begin{array}{l}0.0000 \\
0.0000 \\
0.000\end{array}$ & 0.0000 & $\begin{array}{l}0.0000 \\
0.000 \\
0.000\end{array}$ & $\begin{array}{l}0.0000 \\
0.0000 \\
0.00\end{array}$ & . 0.0000 \\
\hline $\mathrm{Fat}$ & 0.000 & 0.0010 & 0.0000 & 0.0000 & 0.0000 & 0,0000 & o.coses & & 0.0000 & 0.0000 & $\begin{array}{l}0.0000 \\
0.0000 \\
0.00\end{array}$ \\
\hline s. & 然.0000 & $\begin{array}{l}0.0000 \\
0.0000 \\
0.00\end{array}$ & 0000 & 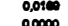 & 些.0000 & 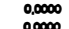 & 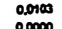 & & o. 0.000 & & $\begin{array}{l}0.0000 \\
0000\end{array}$ \\
\hline ond peres & 0 & 0.0000 & 0.0000 & . & $\begin{array}{l}0.0000 \\
0.0000\end{array}$ & $\begin{array}{l}0.0000 \\
0.0000\end{array}$ & $\begin{array}{l}0.0000 \\
0.0000\end{array}$ & 0.0 & $\begin{array}{l}0.0000 \\
0.0000\end{array}$ & 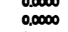 & $\begin{array}{l}0.0000 \\
0.0000\end{array}$ \\
\hline$\infty$ & $\begin{array}{l}0.0000 \\
0.0000\end{array}$ & $\begin{array}{l}0.0000 \\
0.0000\end{array}$ & 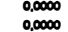 & $\begin{array}{l}0.0000 \\
0.0000 \\
0.000\end{array}$ & $\begin{array}{l}0.0000 \\
0.0000 \\
0.000\end{array}$ & $\begin{array}{l}0.0000 \\
0.0000\end{array}$ & 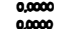 & $\begin{array}{l}0.0000 \\
0.000 \\
0.000\end{array}$ & 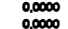 & 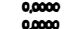 & 0 \\
\hline 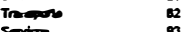 & 0.0000 & $\begin{array}{l}0.0063 \\
00000 \\
0.000\end{array}$ & 0.0 & 0 & 0.0000 & 年 & 年 & 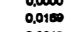 & 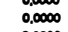 & 年 & 年 \\
\hline & & & & 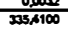 & 然 & 0.00000 & 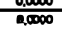 & & & 0.0 & \\
\hline 25 & $\begin{array}{l}0.00000 \\
0.0000\end{array}$ & $\begin{array}{l}0.0000 \\
0.0000 \\
0.00\end{array}$ & $\begin{array}{l}0.0000 \\
0 \times 0000\end{array}$ & 告 00000 & $\begin{array}{l}0.0000 \\
0000 \\
0.00\end{array}$ & 我 & 0.0000 & 0.11 & 0.00 & 0.1. & 20.0700 \\
\hline 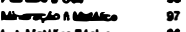 & 0.00000 & 0.1000 & 0,0000 & 0.0000 & 0.3500 & $\begin{array}{l}0.0000 \\
0.0000\end{array}$ & $\begin{array}{l}0.0000 \\
0.0000\end{array}$ & $\begin{array}{l}0.0000 \\
\text { s.1000 }\end{array}$ & $\begin{array}{l}0.0000 \\
0.0000\end{array}$ & $\begin{array}{l}0.000 \\
0.0000\end{array}$ & $\begin{array}{l}0.00000 \\
130.4000\end{array}$ \\
\hline & 0,0 & $\begin{array}{l}0.0000 \\
0.2000 \\
0.00\end{array}$ & $\begin{array}{l}0,0000 \\
1 \times 00 \\
1000\end{array}$ & $\begin{array}{l}0.000 \\
3,2000 \\
3\end{array}$ & 0.0 & $\begin{array}{l}0.0000 \\
0.200\end{array}$ & & & $\begin{array}{l}0.2100 \\
0.000 \\
0.000\end{array}$ & & 102000 \\
\hline 100 & 0.1800 & .00000 & 20000 & 10000 & 0.3500 & 0.0000 & 02000 & 13 & 0,0000 & $m$ & 1.0000 \\
\hline 101 & 0.00 & $\begin{array}{l}0.0000 \\
0.0000\end{array}$ & $\begin{array}{l}0.0000 \\
0.0000\end{array}$ & & 0.0 & $\begin{array}{l}0.0000 \\
0.0000 \\
0.00\end{array}$ & 0.0 & & & & 我 \\
\hline${ }_{100}$ & 0.0000 & 0,000 & 0.0000 & 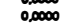 & 0.0000 & 0.0000 & 0.1400 & & 0.0 & 0,0100 & 20,8000 \\
\hline $\begin{array}{l}104 \\
105\end{array}$ & 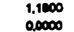 & $\begin{array}{l}0.71100 \\
0.0000\end{array}$ & $\begin{array}{l}5.5000 \\
0.5000\end{array}$ & & & $\begin{array}{l}0.1500 \\
0.1100\end{array}$ & $\begin{array}{l}0.1850 \\
0.0000 \\
0.000\end{array}$ & 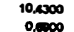 & 0.0 & $0.0 \times 0$ & 25000 \\
\hline 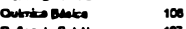 & 0.0000 & 0,0000 & 0,0 & 0.500 & 1,4000 & . & 0.1200 & is & 0.0 & & 000 \\
\hline & 02 & $\begin{array}{l}1.5000 \\
0.0000 \\
0.00\end{array}$ & $\begin{array}{l}7.14 \\
02\end{array}$ & 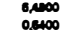 & 22 & 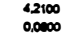 & 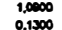 & $\begin{array}{l}0,4000 \\
10000\end{array}$ & $\begin{array}{l}0.1200 \\
0.1900\end{array}$ & 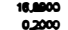 & $\begin{array}{l}2,20000 \\
22,4500\end{array}$ \\
\hline 100 & $0=0000$ & 0.5500 & 22000 & 3.010 & 0.00 & 00000 & 02000 & 3.0 & 0.0 & 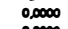 & .0000 \\
\hline 1110 & & 0,0000 & (א. & 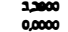 & 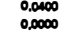 & $\begin{array}{l}0.11000 \\
0.0200\end{array}$ & $\begin{array}{l}0.1200 \\
0.0000\end{array}$ & 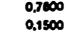 & $\begin{array}{l}0.0000 \\
0.0000 \\
0.00\end{array}$ & $\begin{array}{l}0.0,0 \\
0.0\end{array}$ & $\begin{array}{l}0.0000 \\
0.0000 \\
0.00\end{array}$ \\
\hline 112 & $20 s$ & 220400 & 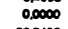 & 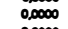 & 0.00000 & 0.0000 & 0.00 & 0.00000 & 0.0 & $0 .$, & 0.0000 \\
\hline 113 & $\begin{array}{l}0.00000 \\
00000\end{array}$ & $\begin{array}{l}0.0000 \\
3.000\end{array}$ & 002000 & m & 0.6 & 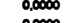 & 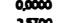 & 19 & .0.00000 & & 0.0000 \\
\hline${ }_{115}^{115}$ & 我, & Dats & 221 & w & 0.0 & 0.0 & $\begin{array}{l}20000 \\
0.000\end{array}$ & $0 x$ & & 我 & 0.0 \\
\hline 118 & 0.0000 & $\begin{array}{l}0.0000 \\
0.0000\end{array}$ & 2.0 & 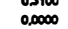 & $1 \mathrm{~N}$ & $\begin{array}{l}0.0000 \\
0.0000\end{array}$ & 0.00 & 15. & $\begin{array}{l}0.0 \\
0.0\end{array}$ & 年 & 我 \\
\hline 117 & 0.0000 & 0,0000 & 2.15 & 0.0000 & 0.00 & 000000 & 10000 & 12500 & 0.0000 & & 0.00000 \\
\hline (2) & 0 & $\begin{array}{l}1.7000 \\
0.400 \\
0.00\end{array}$ & $\begin{array}{l}3.1000 \\
0.000 \\
0.000\end{array}$ & 年 & 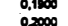 & 年 & 年 & rac. & & $\begin{array}{l}0.01200 \\
0.000\end{array}$ & smo \\
\hline 100 & $x$ & 1.0700 & 2,50 & c.sod & 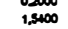 & $\begin{array}{l}0.0000 \\
0.000\end{array}$ & 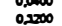 & 8. & & 301500 & $\begin{array}{l}0.0000 \\
7.1000 \\
7\end{array}$ \\
\hline 121 & & 0.2000 & id & $1 \pi$ & 0,1 & 0.0100 & 0.1100 & 18 & 0.0 & 02 & 0.0000 \\
\hline 122 & 2.1 & 220000 & & & 10.3 & 2.5750 & & & & o & 0.0000 \\
\hline $\begin{array}{l}124 \\
124\end{array}$ & & $\begin{array}{l}3.1,100 \\
0.100\end{array}$ & 11,1 & & & $\begin{array}{l}\infty \\
\infty\end{array}$ & $\infty 00$ & $\begin{array}{l}12000 \\
20000\end{array}$ & 1.0100 & 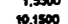 & $\begin{array}{l}3000 \\
10,700 \\
1070\end{array}$ \\
\hline$\frac{125}{125}$ & & & $\cdots$ & & & & & & & & 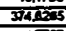 \\
\hline $\begin{array}{c}128 \\
127\end{array}$ & (26110 & $\begin{array}{l}3.701 \\
0.002 \\
0.020\end{array}$ & $\begin{array}{l}20.1848 \\
20,5781\end{array}$ & 等 & $\begin{array}{l}0.20201 \\
0.2554\end{array}$ & $\begin{array}{l}0.1913 \\
0.7277\end{array}$ & 然 & בדינ217 & 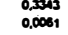 & 12122 & 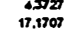 \\
\hline 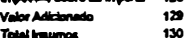 & cosios & $\underset{510000}{5108010}$ & 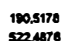 & 101.0111 & $\underset{20.7 \pi}{20, \pi}$ & $\begin{array}{l}34.31000 \\
n, 17000\end{array}$ & actor & 10000000 & $\begin{array}{r}7.5241 \\
152811\end{array}$ & 102000 & 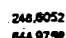 \\
\hline
\end{tabular}




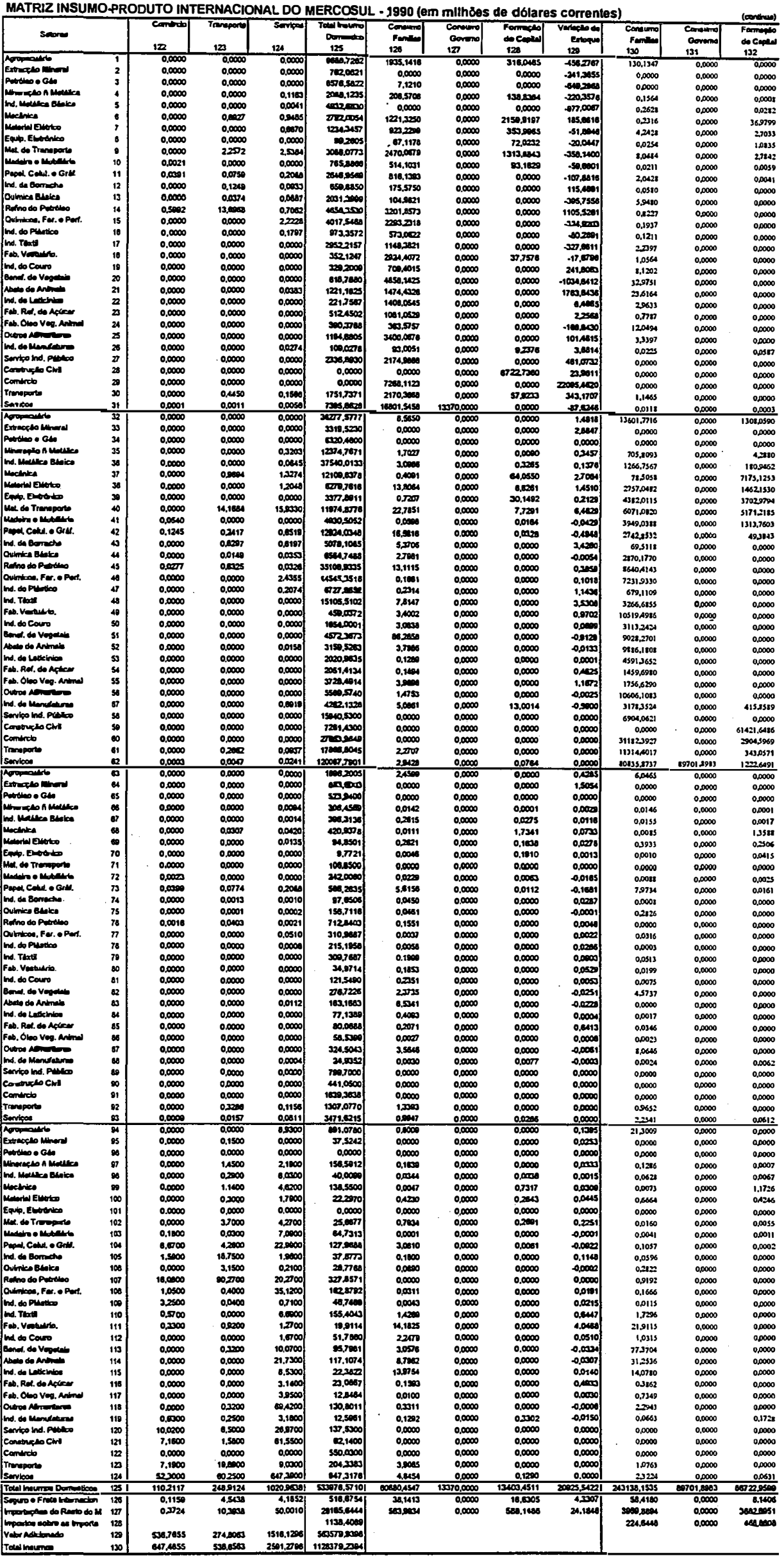




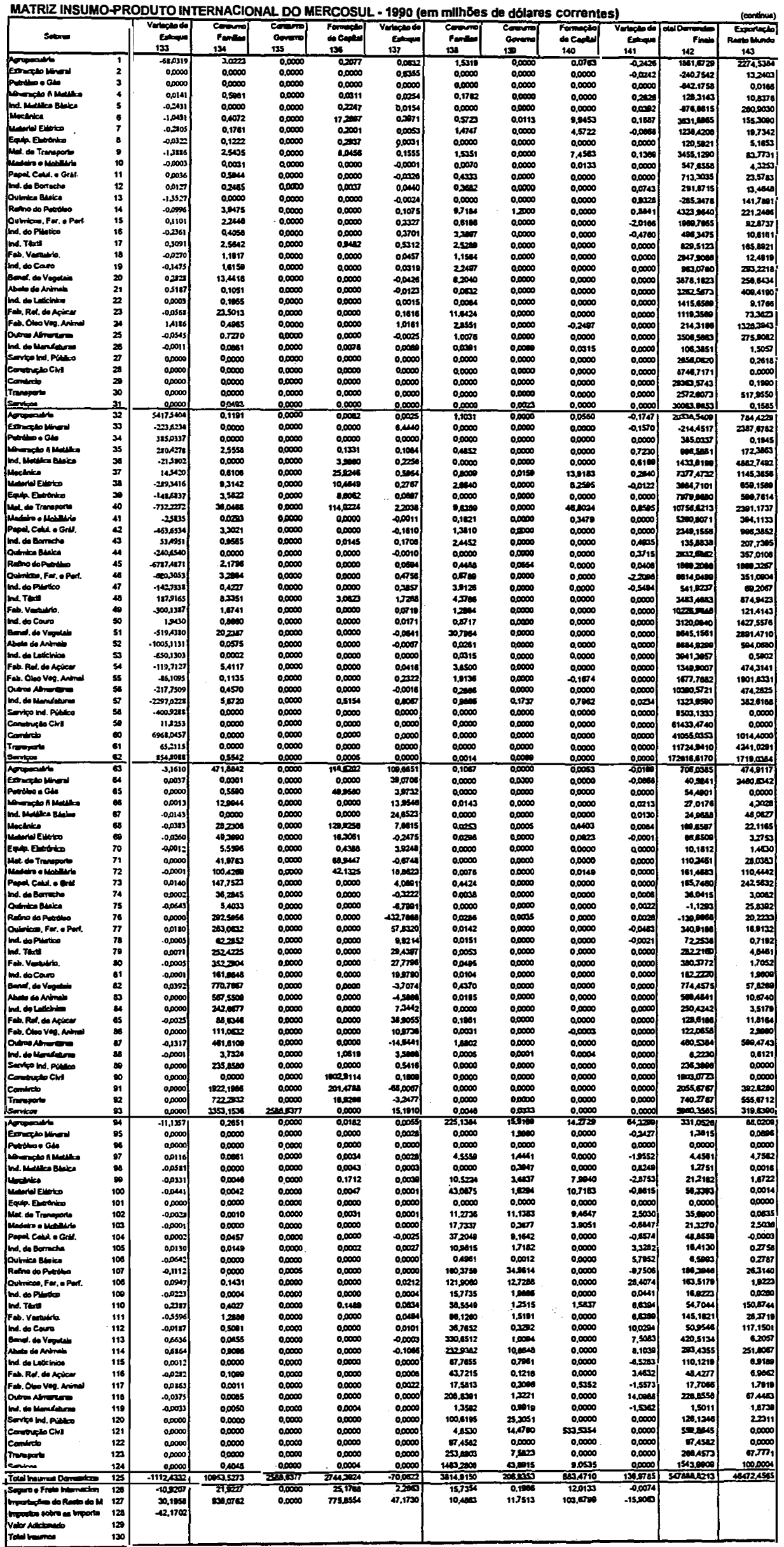




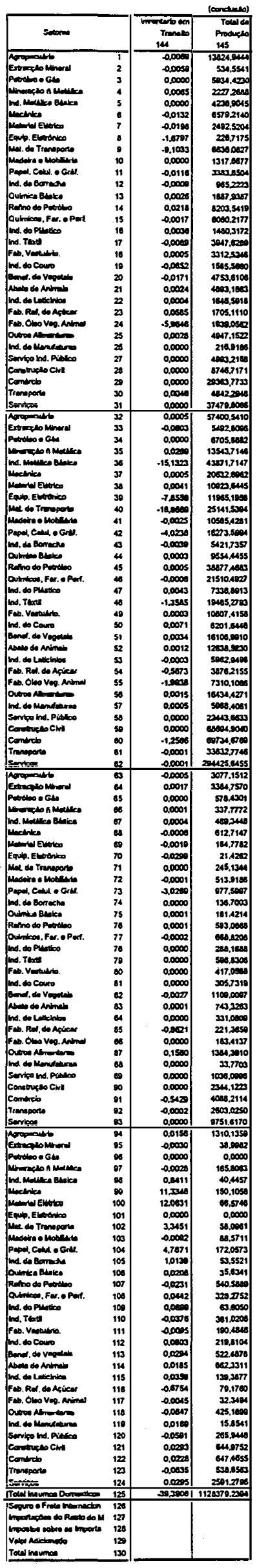


APÊNDICES 2 - PRODUÇÃO, VALOR ADICIONADO E COMÉRCIO INTERREGIONAL INDUZIDO PELA DEMANDA FINAL 


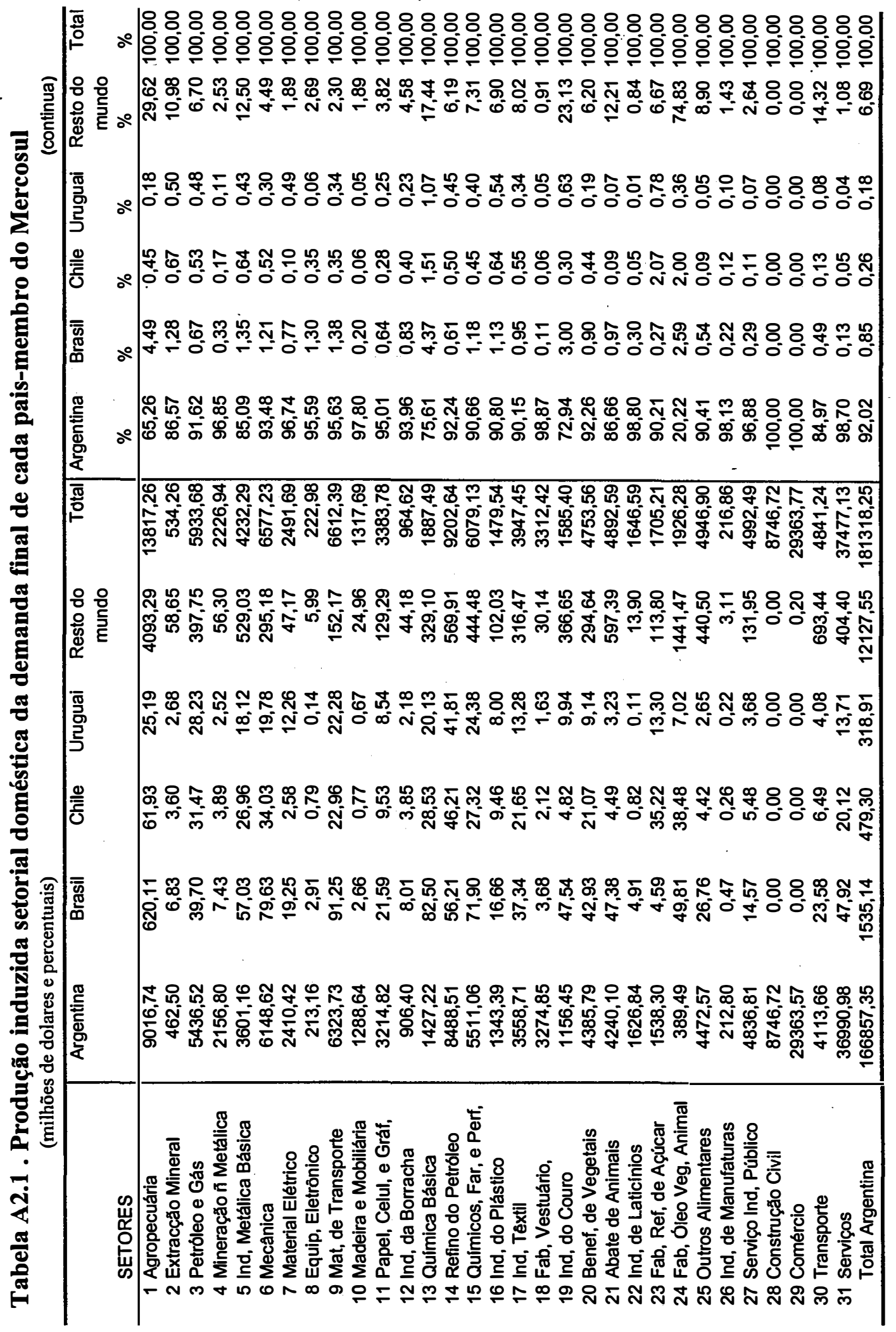




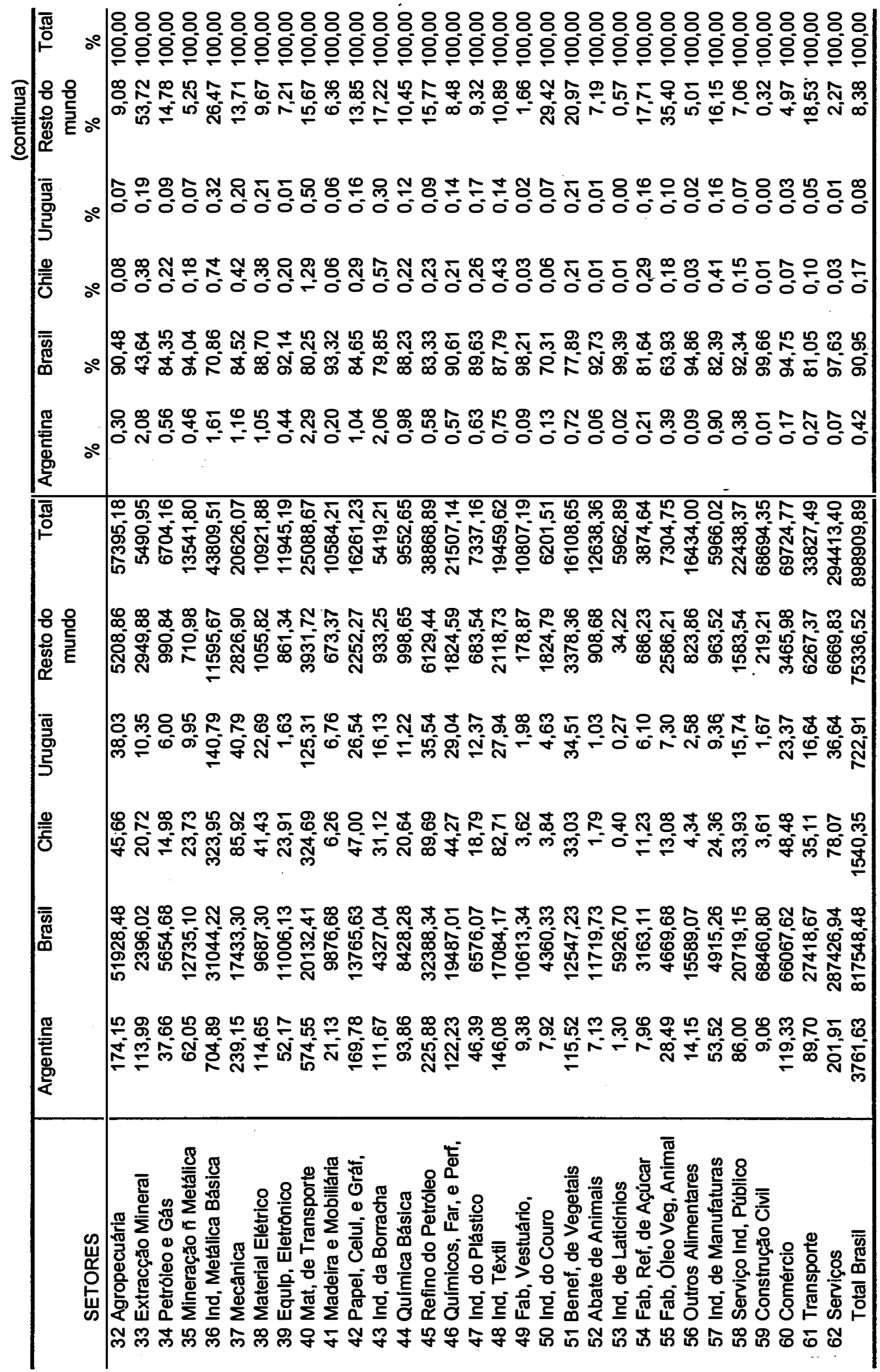




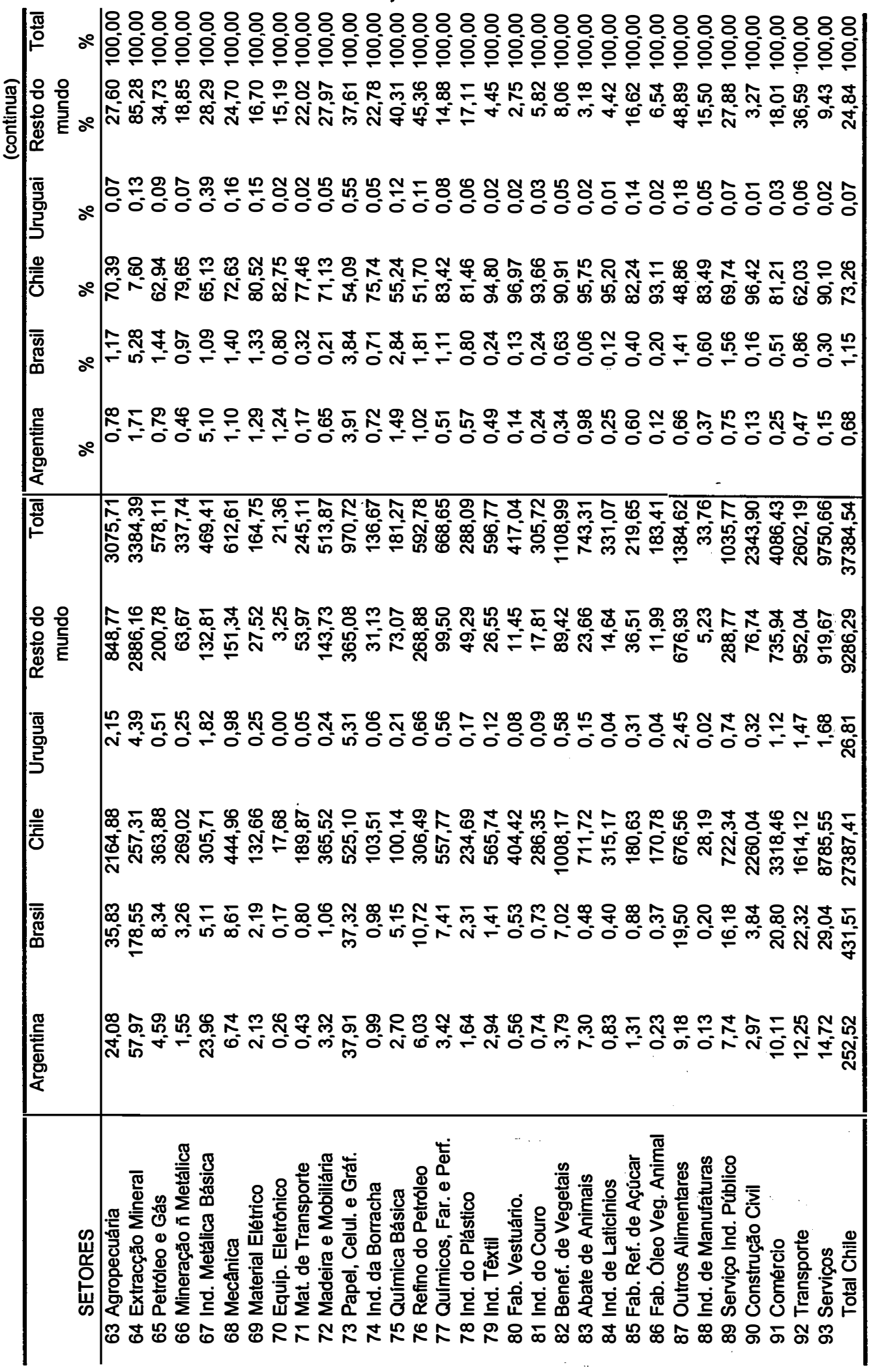




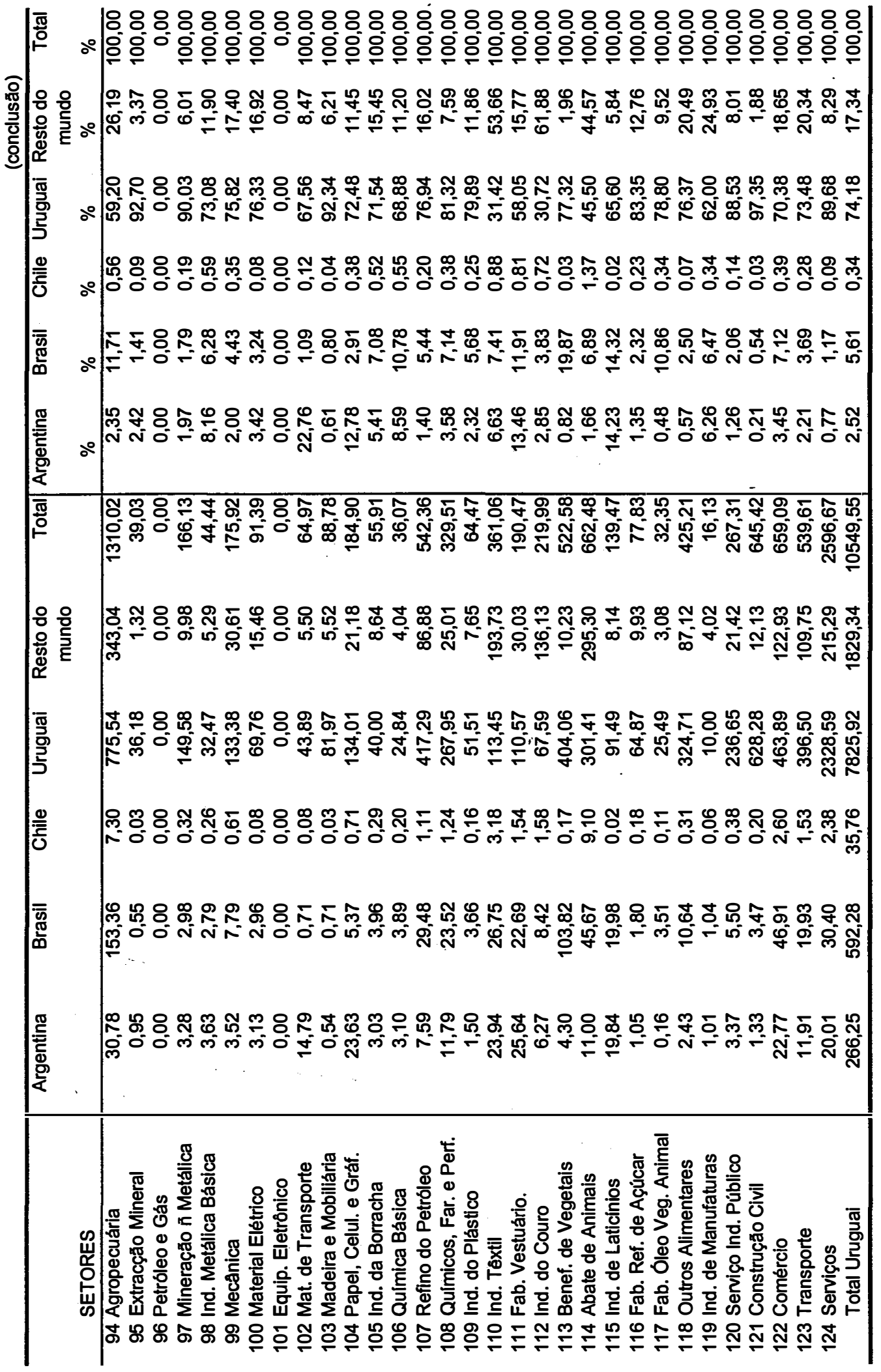









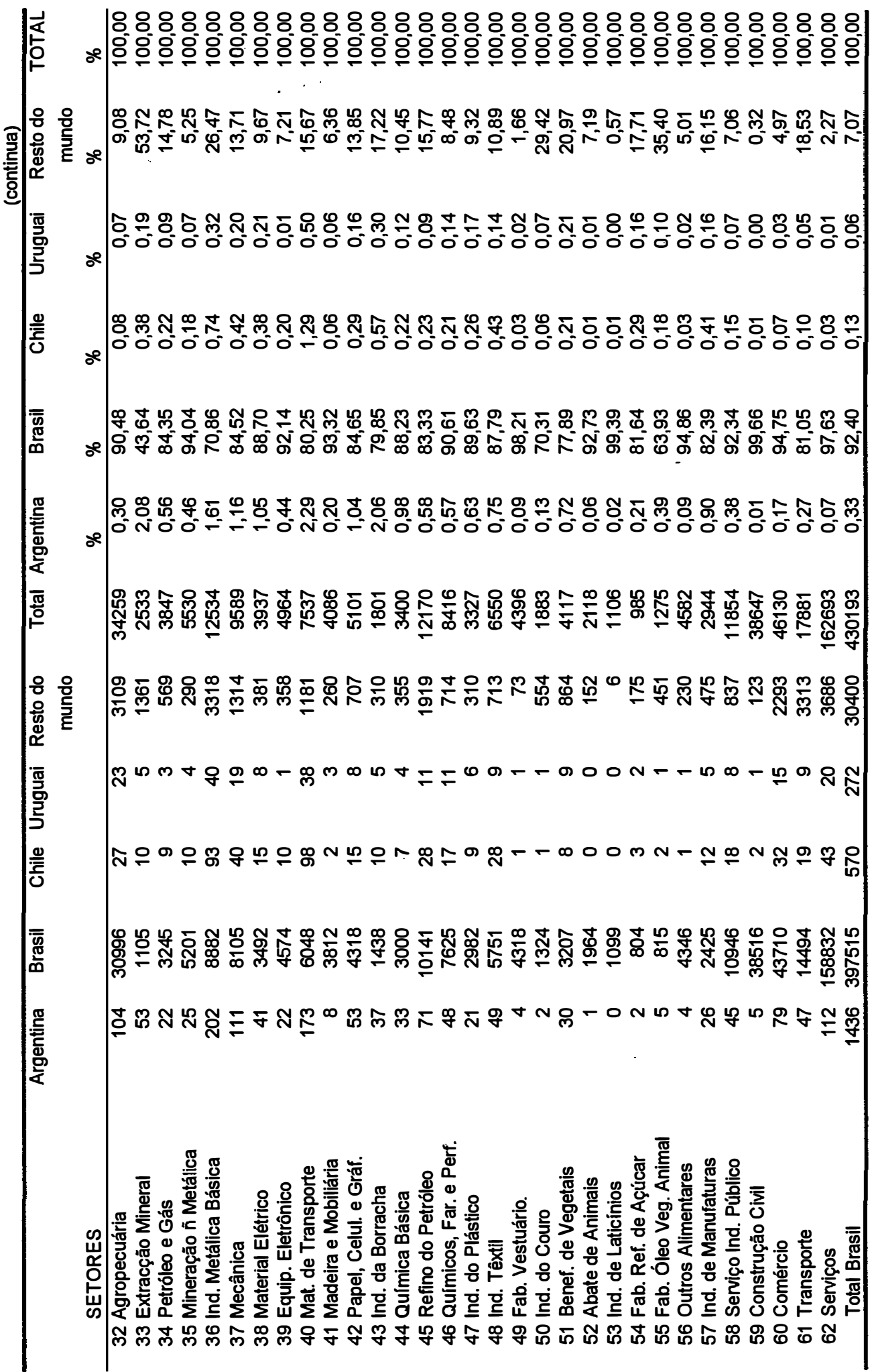




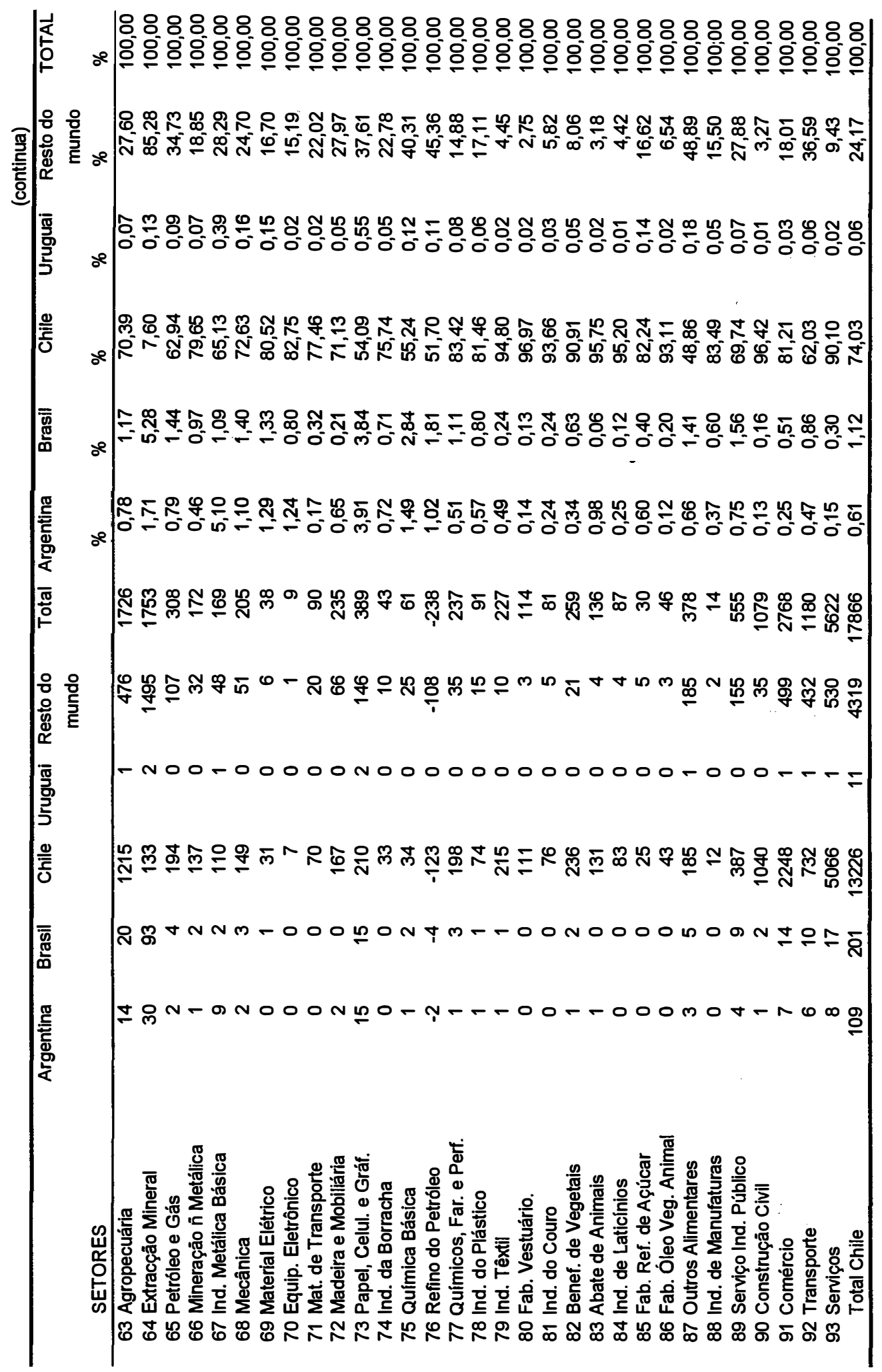




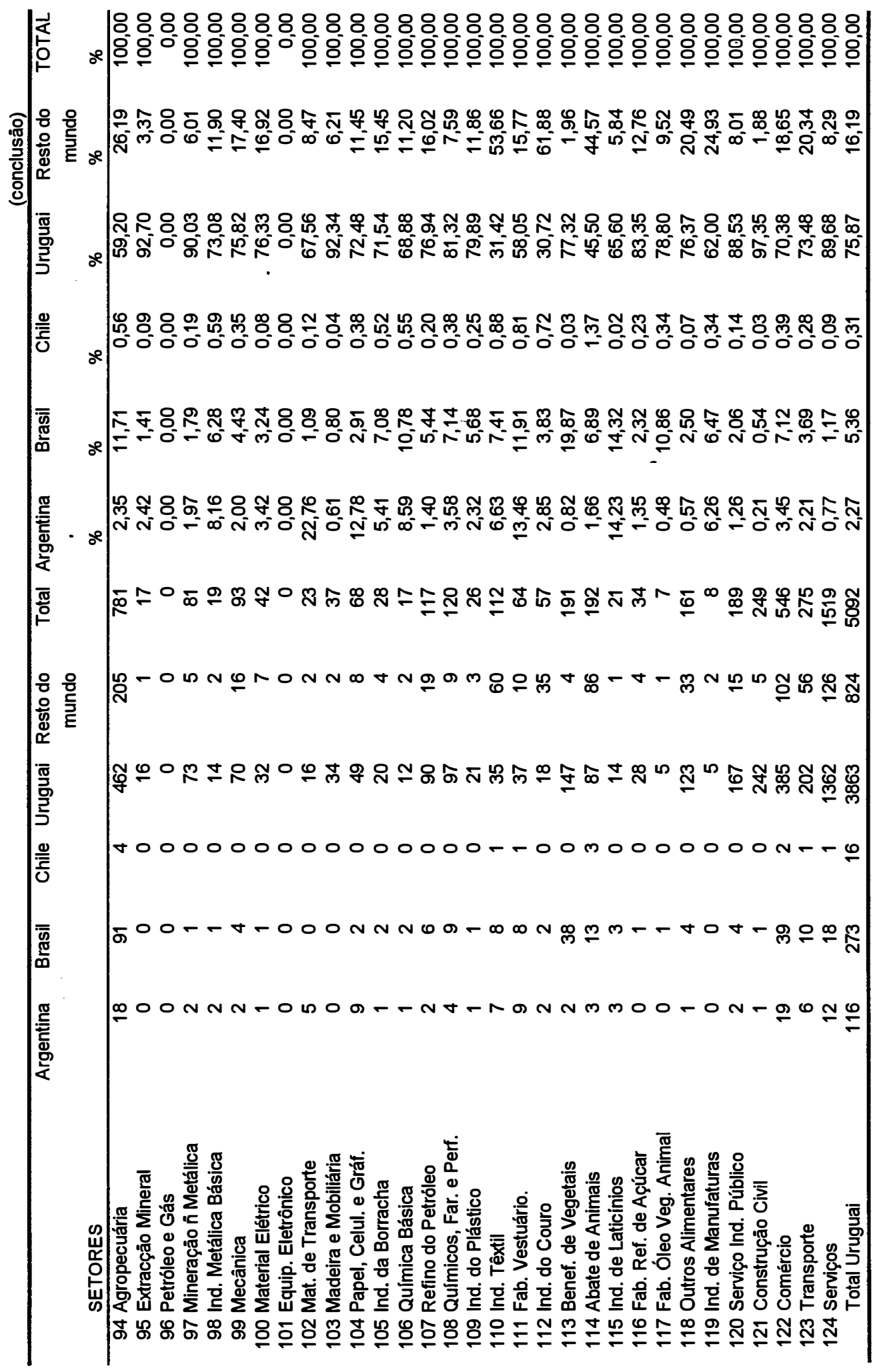


Tabela A2.3 . Valor das importações inter-regionais induzidas pela demanda final de cada país-membro do Mercosul (em milhões de dolares)

\begin{tabular}{|c|c|c|c|c|c|}
\hline SETORES & Argentina & Brasil & Chile & Uruguai & Resto do mundo \\
\hline 1 Agropecuária & 3 & 418 & 11 & 7 & 78 \\
\hline 2 Extracção Mineral & 0 & 1 & 0 & 1 & 1 \\
\hline 3 Petróleo e Gás & 0 & 0 & 0 & 0 & 0 \\
\hline 4 Mineração ñ Metálica & 0 & 2 & 1 & 1 & 1 \\
\hline 5 Ind. Metálica Básica & 0 & 7 & 7 & 4 & 5 \\
\hline 6 Mecānica & 0 & 20 & 8 & 3 & 9 \\
\hline 7 Material Elétrico & 0 & 5 & 0 & 3 & 1 \\
\hline 8 Equip. Eletrônico & 0 & 1 & 0 & 0 & 0 \\
\hline 9 Mat. de Transporte & 2 & 58 & 6 & 7 & 13 \\
\hline 10 Madeira e Mobiliária & 0 & 0 & 0 & 0 & 0 \\
\hline 11 Papel, Celul. e Gráf. & 1 & 6 & 3 & 4 & 3 \\
\hline 12 Ind. da Borracha & 0 & 2 & 2 & 1 & 2 \\
\hline 13 Química Básica & 1 & 48 & 18 & 10 & 15 \\
\hline 14 Refino do Petróleo & 1 & 11 & 29 & 21 & 24 \\
\hline 15 Químicos, Far. e Perf. & 1 & 20 & 9 & 14 & 8 \\
\hline 16 Ind. do Plástico & 0 & 6 & 5 & 2 & 3 \\
\hline 17 Ind. Têxtil & 1 & 18 & 10 & 5 & 6 \\
\hline 18 Fab. Vestuário. & 0 & 0 & 0 & 0 & 0 \\
\hline 19 Ind. do Couro & 1 & 33 & 2 & 6 & 21 \\
\hline 20 Benef. de Vegetais & 0 & 5 & 6 & 0 & 1 \\
\hline 21 Abate de Animais & 0 & 7 & 1 & 0 & 1 \\
\hline 22 Ind. de Laticínios & 0 & 1 & 0 & 0 & 0 \\
\hline 23 Fab. Ref. de Açúcar & 0 & 1 & 11 & 1 & 3 \\
\hline 24 Fab. Óleo Veg. Animal & 0 & 32 & 34 & 4 & 13 \\
\hline 25 Outros Alimentares & 0 & 4 & 1 & 0 & 1 \\
\hline 26 Ind. de Manufaturas & 0 & 0 & 0 & 0 & 0 \\
\hline 27 Serviço Ind. Público & 0 & 0 & 0 & 0 & 0 \\
\hline 28 Construçāo Civil & 0 & 0 & 0 & 0 & 0 \\
\hline 29 Comércio & 0 & 0 & 0 & 0 & 0 \\
\hline 30 Transporte & 0 & 4 & 1 & 1 & 2 \\
\hline 31 Serviços & 0 & 0 & 0 & 0 & 0 \\
\hline Total Argentina & 13 & 709 & 167 & 96 & 211 \\
\hline 32 Agropecuária & 28 & 1 & 1 & 5 & 5 \\
\hline 33 Extracção Mineral & 81 & 2 & 3 & 6 & 17 \\
\hline 34 Petróleo e Gás & 0 & 0 & 0 & 0 & 0 \\
\hline 35 Mineração ñ Metálica & 23 & 0 & 6 & 2 & 3 \\
\hline 36 Ind. Metálica Básica & 233 & 8 & 106 & $4 \overline{7}$ & 79 \\
\hline 37 Mecânica & 58 & 1 & 12 & 5 & 10 \\
\hline 38 Material Elétrico & 58 & 1 & 8 & 6 & 4 \\
\hline 39 Equip. Eletrônico & 4 & 0 & 4 & 0 & 1 \\
\hline 40 Mat. de Transporte & 372 & 7 & 82 & 33 & 45 \\
\hline 41 Madeira e Mobiliária & 6 & 0 & 0 & 3 & 0 \\
\hline 42 Papel, Celul. e Gráf. & 80 & 2 & 19 & 12 & 13 \\
\hline 43 Ind. da Borracha & 48 & 1 & 9 & 4 & 9 \\
\hline 44 Química Básica & 57 & 2 & 8 & 4. & 10 \\
\hline 45 Refino do Petróleo & 28 & 1 & 16 & 1 & 14 \\
\hline 46 Químicos, Far. e Perf. & 47 & 3 & 14 & 16 & 13 \\
\hline 47 Ind. do Plástico & 15 & 1 & 5 & 3 & 4 \\
\hline 48 Ind. Têxtil & 60 & 2 & 31 & 9 & 13 \\
\hline 49 Fab. Vestuário. & 2 & 0 & 0 & 0 & 0 \\
\hline 50 ind. do Couro & 1 & 0 & 1 & 2 & 3 \\
\hline
\end{tabular}


(continua)

\begin{tabular}{|c|c|c|c|c|c|}
\hline SETORES & Argentina & Brasil & Chile & Uruguai & $\begin{array}{r}\text { Resto do } \\
\text { mundo }\end{array}$ \\
\hline 51 Benef. de Vegetais & 16 & 0 & $\overline{8}$ & 0 & 2 \\
\hline 52 Abate de Animais & 0 & 0 & 0 & 0 & 0 \\
\hline 53 Ind. de Laticinios & 0 & 0 & 0 & 0 & 0 \\
\hline 54 Fab. Ref. de Açúcar & 0 & 0 & 2 & 0 & 1 \\
\hline 55 Fab. Óleo Veg. Animal & 10 & 0 & 7 & 2 & 3 \\
\hline 56 Outros Alimentares & 2 & 0 & 1 & 0 & 0 \\
\hline 57 Ind. de Manufaturas & 1 & 0 & 2 & 1 & 1 \\
\hline 58 Serviço Ind. Público & 0 & 0 & 0 & 0 & 0 \\
\hline 59 Construção Civil & 0 & 0 & 0 & 0 & 0 \\
\hline 60 Comércio & 0 & 0 & 0 & 0 & 0 \\
\hline 61 Transporte & 2 & 0 & 1 & 0 & 1 \\
\hline 62 Serviços & 0 & 0 & 0 & 0 & 0 \\
\hline Total Brasil & 1232 & 34 & 349 & 161 & 253 \\
\hline 63 Agropecuária & 8 & 19 & 0 & 1 & 4 \\
\hline 64 Extracção Mineral & 45 & 156 & 2 & 4 & 51 \\
\hline 65 Petróleo e Gás & 0 & 0 & 0 & 0 & 0 \\
\hline 66 Mineração ñ Metálica. & 0 & 0 & 0 & 0 & 0 \\
\hline 67 Ind. Metálica Básica & 19 & 1 & 0 & 1 & 2 \\
\hline 68 Mecãnica & 2 & 1 & 0 & 0 & 0 \\
\hline 69 Material Elétrico & 1 & 0 & 0 & 0 & 0 \\
\hline 70 Equip. Eletrônico & 0 & 0 & 0 & 0 & 0 \\
\hline 71 Mat. de Transporte & 0 & 0 & 0 & 0 & 0 \\
\hline 72 Madeira e Mobiliária & 2 & 0 & 0 & 0 & 0 \\
\hline 73 Papel, Celul. e Gráf. & 26 & 21 & 0 & 4 & 5 \\
\hline 74 Ind. da Borracha & 0 & 0 & 0 & 0 & 0 \\
\hline 75 Química Básica & 1 & 2 & 0 & 0 & 0 \\
\hline 76 Refino do Petróleo & 0 & 0 & 0 & 0 & 0 \\
\hline 77 Químicos, Far. e Perf. & 1 & 3 & 0 & 0 & 0 \\
\hline 78 Ind. do Plástico & 0 & 0 & 0 & 0 & 0 \\
\hline 79 Ind. Têxtil & 2 & 0 & 0 & 0 & 0 \\
\hline 80 Fab. Vestuário. & 0 & 0 & 0 & 0 & 0 \\
\hline 81 Ind. do Couro & 0 & 0 & 0 & 0 & 0 \\
\hline 82 Benef. de Vegetais & 0 & 1 & 0 & 0 & 0 \\
\hline 83 Abate de Animais & 0 & 0 & 0 & 0 & 0 \\
\hline 84 Ind. de Laticinios & 0 & 0 & 0 & 0 & 0 \\
\hline 85 Fab. Ref. de Açúcar & 0 & 0 & 0 & 0 & 0 \\
\hline 86 Fab. Óleo Veg. Anịmal & 0 & 0 & 0 & 0 & 0 \\
\hline 87 Outros Alimentares & 4 & 9 & 0 & 0 & 1 \\
\hline 88 Ind. de Manufaturas & 0 & 0 & 0 & 0 & 0 \\
\hline 89 Serviço Ind. Público & 0 & 0 & 0 & 0 & 0 \\
\hline 90 Construção Civil & 0 & 0 & 0 & 0 & 0 \\
\hline 91 Comércio & 0 & 5 & 0 & 0 & 1 \\
\hline 92 Transporte & 1 & 4 & 0 & 0 & 1 \\
\hline 93 Serviços & 0 & 2 & 0 & 0 & 0 \\
\hline Total Chile & 114 & 226 & 2 & 11 & 68 \\
\hline 94 Agropecuária & 3 & 68 & 1 & 0 & 13 \\
\hline 95 Extracção Mineral & 1 & 0 & 0 & 0 & 0 \\
\hline 96 Petróleo e Gás & 0 & 0 & 0 & 0 & 0 \\
\hline 97 Mineração ñ Metálica & 2 & 1 & 0 & 0 & 0 \\
\hline 98 Ind. Metálica Básica & 3 & 2 & 0 & 0 & 1 \\
\hline 99 Mecânica & 1 & 1 & 0 & 0 & 0 \\
\hline 100 Material Elétrico & 2 & 1 & 0 & 0 & 0 \\
\hline
\end{tabular}

(conclusão) 


\begin{tabular}{|c|c|c|c|c|c|}
\hline SETORES & Agentina & Brasil & Chile & Uruguai & $\begin{array}{r}\text { Resto do } \\
\text { mundo }\end{array}$ \\
\hline 101 Equip. Eletrônico & 0 & 0 & 0 & 0 & $\overline{0}$ \\
\hline 102 Mat. de Transporte & 13 & 0 & 0 & 0 & 0 \\
\hline 103 Madeira e Mobiliária & 0 & 0 & 0 & 0 & 0 \\
\hline 104 Papel, Celul. e Gráf. & 14 & 0 & 0 & 0 & 1 \\
\hline 105 Ind. da Borracha & 2 & 2 & 0 & 0 & 1 \\
\hline 106 Química Básica & 2 & 2 & 0 & 0 & 1 \\
\hline 107 Refino do Petróleo & 0 & 10 & 0 & 0 & 2 \\
\hline 108 Quimicos, Far. e Perf. & 9 & 16 & 1 & 0 & 2 \\
\hline 109 Ind. do Plástico & 0 & 1 & 0 & 0 & 0 \\
\hline 110 Ind. Têxtil & 11 & 13 & 2 & 0 & 2 \\
\hline 111 Fab. Vestuário. & 7 & 0 & 0 & 0 & 0 \\
\hline 112 Ind. do Couro & 1 & 4 & 1 & 0 & 2 \\
\hline 113 Benef. de Vegetais & 1 & 12 & 0 & 0 & 1 \\
\hline 114 Abate de Animais & 0 & 10 & 8 & 0 & 1 \\
\hline 115 Ind. de Laticinios & 6 & 5 & 0 & 0 & 0 \\
\hline 116 Fab. Ref. de Açúcar & 0 & 0 & 0 & 0 & 0 \\
\hline 117 Fab. Óleo Veg. Animal & 0 & 2 & 0 & 0 & 0 \\
\hline 118 Outros Alimentares & 0 & 2 & 0 & 0 & 0 \\
\hline 119 Ind. de Manufaturas & 0 & 0 & 0 & 0 & 0 \\
\hline 120 Serviço Ind. Público & 0 & 0 & 0 & 0 & 0 \\
\hline 121 Construção Civil & 0 & 0 & 0 & 0 & 0 \\
\hline 122 Comércio & 0 & 0 & 0 & 0 & 0 \\
\hline 123 Transporte & 3 & 4 & 1 & 0 & 2 \\
\hline 124 Serviços & 0 & 2 & 0 & 0 & 0 \\
\hline Total Uruguai & 78 & 160 & 14 & 0 & 30 \\
\hline
\end{tabular}

